University of Rhode Island

DigitalCommons@URI

Open Access Dissertations

2016

\title{
The Potential of Indonesian Microalgal Strains to Support Eastern White Shrimp (Litopenaeus vannamei) Aquaculture
}

Wa Iba

University of Rhode Island, wa.iba@uho.ac.id

Follow this and additional works at: https://digitalcommons.uri.edu/oa_diss

\section{Recommended Citation}

Iba, Wa, "The Potential of Indonesian Microalgal Strains to Support Eastern White Shrimp (Litopenaeus vannamei) Aquaculture" (2016). Open Access Dissertations. Paper 500.

https://digitalcommons.uri.edu/oa_diss/500

This Dissertation is brought to you for free and open access by DigitalCommons@URI. It has been accepted for inclusion in Open Access Dissertations by an authorized administrator of DigitalCommons@URI. For more information, please contact digitalcommons-group@uri.edu. 
THE POTENTIAL OF INDONESIAN MICROALGAL STRAINS TO SUPPORT EASTERN WHITE SHRIMP (Litopenaeus vannamei) AQUACULTURE

\section{BY}

WA IBA

A DISSERTATION SUBMITTED IN PARTIAL FULFILLMENT OF THE REQUIREMENTS FOR THE DEGREE OF DOCTOR OF PHILOSOPHY

IN

BIOLOGY AND ENVIRONMENTAL SCIENCES

UNIVERSITY OF RHODE ISLAND 


\section{DOCTOR OF PHILOSOPHY DISSERTATION}

OF

WA IBA

\section{APPROVED:}

Dissertation Committee:

Major Professor Michael A. Rice

Gary H. Wikfors

David A. Bengtson

Lucie Maranda

Lenore Martin

Nasser H. Zawia

DEAN OF THE GRADUATE SCHOOL

\section{UNIVERSITY OF RHODE ISLAND}

2016 


\begin{abstract}
Indonesia is well known for abundant aquatic resources, both marine and freshwater, including fishes, zooplankton and phytoplanktonic microalgae. However, relatively little information is available about microalgal resources despite their potential to be used as live feed in the hatchery phase of aquaculture of a number of marine species. The use of local microalgae is desirable in local hatcheries because they tend to grow better with high yield under local conditions, thus reducing the risk of culture crash and production cost while preventing disease vectors that may introduced by foreign microalgae strains. In this dissertation, the potential of Indonesian microalgae to be used in shrimp hatcheries is investigated by isolating and growing the microalgae from Kendari Bay and Wanggu River estuary in South East (SE)-Sulawesi, Indonesia, under controlled conditions, assessing the growth of shrimp larvae using the local isolates as food and measuring the nutritional content of these local microalgal isolates.

Four strains of microalgae were successfully isolated using flow cytometry and the micro-pipet isolation technique. Those strains are denoted as Kb1-2 identified as Chaetoceros sp, Kb1-3, Kb1-5 and Kb2-6 identified as Melosira cf moniliformis. Melosira cf moniliformis was excluded from the microalgal growth experiment due to its larger cell size which were $>10 \mu \mathrm{m}$. The growth for 15 days and cell size of those strains was investigated under four different salinities, 20, 25, 30 and 35 psu and growth rates were compared to the growth of T-ISO (Tisochrysis lutea), Chaetoceros neogracile and Tetraselmis chui. Salinity did not affect the growth of Indonesian microalgae, similar to T. chui, Ti. lutea and C. neogracile, but did affect microalgal final
\end{abstract}


density. Two Indonesian microalgal strains, Kb1-3 and Kb1-5, had the highest yield, among all microalgae tested, whereas, yield of Kb1-2 was similar to Ti. lutea and $C$. neogracile. Cell sizes of three of the four Indonesian microalgae ranged from 1.2-11.8 $\mu \mathrm{m}$, considered a suitable size for shrimp larvae which is $<20 \mu \mathrm{m}$ The Indonesian strains may be potential for mass culture and to be used in shrimp hatcheries based upon the cell sizes, their ability to survive long culture periods and tolerate a wide salinity range.

The subsequent experiment to assess the suitability of the Indonesian microalgae strains as food for hatchery-reared white shrimp (Litopenaeus vannamei) larvae confirmed that Indonesian microalgae may be suitable as food for white shrimp larvae, supporting performance similar to that of well-established strains in terms of weight gain, ingestion rate and food conversion index. However, lower survival was observed in shrimp larvae fed on Indonesian strains compared to T. lutea and C. neogracile. Analyses of the nutritional content of Indonesian microalgae revealed that lipid, protein and carbohydrate contents of these strains in late log and stationary phase of growth and were comparable to $T$. lutea during the stationary phase of growth. Of Indonesian microalgae, Kb1-2 contained important $\omega-3$, eicosapentaenoic acid and docosahexaenoic acid (EPA and DHA) and $\omega-6$, arachidonic acid (ARA) when cultured at 25 and 35 psu. Kb1-3 strain contained ARA, EPA and DHA only when cultured at 35 psu whereas Kb1-5 only when cultured at 25 psu. Indonesian microalgae, Kb1-3, had a higher ARA concentration compared to other Indonesian strains and T. lutea. DHA in Indonesia microalgae was similar to $T$. lutea but $T$. lutea had a higher concentration of EPA. This suggests that the use of Kb1-2 and Kb1-5 strains in white 
shrimp hatcheries may be best when cultured at 25 psu and Kb1-3 at 35 psu to supply necessary PUFA at optimal cells density. Other option is mixing these strains with other species, such as T. lutea, that contain higher levels of essential EPA. 


\section{ACKNOWLEDGEMENT}

Life is a journey and everything that happens is for a reason as part of God's grand plan. The experiences that are a part of that journey serve as a path to a better understanding of life itself including the people we meet and in turn, serve us to help one another. My journey as a PhD scholar for almost four years at University of Rhode Island (URI) has been a journey full of people that offered me helping hands in one way or another and I am indebted to them for the rest of my life and this acknowledgment maybe is not enough to express my gratitude for their support and advice throughout that journey.

First and foremost, I want to thank my major adviser, Professor Michael Rice. I am blessed to have Pak Mike as my major adviser who always has time for every problem that I encountered during my time in Rhode Island. He has given me a lot of freedom to do my research and jumped in with directions when needed. His advice on issues of science or other topics is always exceptional and greatly appreciated. I want to thank my co-major adviser, Dr. Gary Wikfors. Gary always has time for committee meetings and has been driving all the way up from Milford, Connecticut to Kingston, Rhode Island. His insight and advice on microalgal science and aquaculture have been a great help to me in order to better understand the field.

I am lucky to have Dr. Lucie Maranda and Dr. David Bengtson in my dissertation committee. Lucie has been a great critic and mentor when I was working in her lab. Her comments and advice for some chapters in the dissertation have been exceptional. Dr. Bengtson was the one that opened the door for me to be admitted to URI Graduate School and I am forever thankful for the opportunity. 
I want to thank Dr. Lenore Martin who allowed me to work in her lab and provided tremendous help with analytical and organic chemistry, a field that is more difficult for me. Her guidance and explanations of chemistry terms has helped me through the most difficult part of my dissertation. I want to mention several people that helped me in my data collection period. Matt Porter, gave me tremendous help with GC-MS. Janet Atoyan, assisted me with the genomic sequencing process. Mike Platek, helped with scanning electron microscopy.

I want to acknowledge the Fulbright-Directorate General of Higher Education (DIKTI), Republic of Indonesia Scholarship that has provided funding for my $\mathrm{PhD}$ here at URI. The collaboration of Fulbright and DIKTI has enabled several Indonesian academic staff to study at U.S. universities. Despite growing disparities among countries as political tensions increase, this kind of collaboration will help to ensure that open-minded and critically-thinking people will remain in academia who will always play an important role in communities around the globe to drive a balanced conversation resulting in a better future. I am forever proud to be among Fulbright Scholars and I hope that I can utilize my expertise to better serve my fellow Indonesian citizens and humanity in general. Many thanks to the Graduate School of URI and the Dean's Office of College of The Environment and Life Sciences (CELS) who helped me with small grants for my research and tuition. Also, I want to offer my gratitude to Dr. Marta Gomez- Chiarri, both as the Department chair and as a member of my defense committee who always has answers for my questions regarding the school administration process. I thank the Rector of University Halu Oleo, Prof. Usman Rianse, who was very supportive to me during my leave to pursue my $\mathrm{PhD}$ at URI. 
I am thankful to my Indonesian friends both at URI and Rhode Island in general for their friendship and support, and my American friends particularly Kim Kaine and Janalyn Taylor, who are always there to offer a helping hand, companionship and advice. Also, I want to thank all of the Coastal Resources Center (CRC) of URI teams particularly Brian Crawford, Glenn Ricci and Anton Post for much support along the way. My sincere thanks go to the teachers of my children at West Kingston Elementary School (WKES) and Broad Rock Middle School (BRMS) who have made my life as a student a lot easier during my journey here at URI.

Last but not least, I want to acknowledge the most important part of my life, my husband, Sahrir and my two beloved children, Fauzan and Izzah. They are my anchor, my spirit and my guiding star that always keep me going no matter how hard life seems. I am thankful for my Mom for her continuous prayers that have been and will forever enlighten my life, my late Dad who left me with a legacy to be a better person every day, my brother and sisters and all my extended family that supported me in many ways that I could never mention one by one. May God bless us all. 


\section{PREFACE}

This dissertation is presented in manuscript format, and is divided into five chapters. Chapter One is a literature review, serving as an introduction and providing context for this work and how it fits into our broader understanding of the importance of microalgae in aquaculture hatchery practices and the possibility to explore other geographical locations for potential microalgae strains that may be used for aquaculture. This manuscript has been published in Asian Fisheries Science. Chapter Two focuses on the growth characteristics of newly isolated microalgae from South East Sulawesi, Indonesia and compares them to other strains used extensively in aquaculture. This manuscript is in preparation for submission to Journal of Applied Phycology. Chapter Three addresses the nutritional composition of the newly isolated microalgae strains from SE- Sulawesi in comparison with Tisochrysis lutea, a widely studied and used strain for aquaculture. This manuscript is in preparation for submission to Aquaculture Research. Chapter Four explores the growth and survival of Eastern Pacific white shrimp (Litopenaues vannamei) fed on the newly isolated microalgae strains from SESulawesi. This manuscript is in preparation for submission to Journal of The World Aquaculture Society. Chapter Five is a speculative discussion on the dissertation as a whole, reflecting on the outcome of all four chapters. The appendix following these chapters includes additional data upon which figures and tables throughout the dissertation are based. 


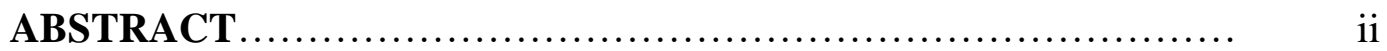

ACKNOWLEDGMENT ......................................

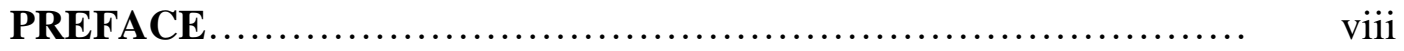

TABLE OF CONTENTS ............................................. ix

LIST OF TABLES ............................................ xii

LIST OF FIGURES .............................................. xiv

\section{CHAPTER 1}

Abstract....................................................... 2

Introduction..................................................... 3

Shrimp nutrition: use of microalgae in early life stages of white

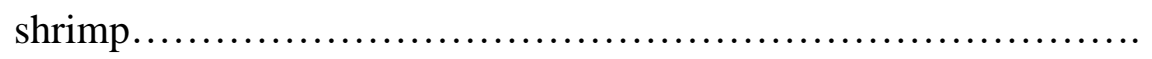

Microalgal isolation and production techniques.................... 14

Conclusions.................................................. 24

References................................................. 26 


\section{CHAPTER 2}

Abstract.............................................................. 41

Introduction......................................................... 42

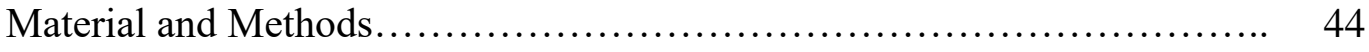

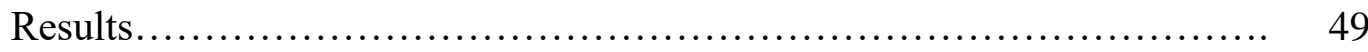

Discussion......................................................... 52

References.......................................................... 56

\section{CHAPTER 3}

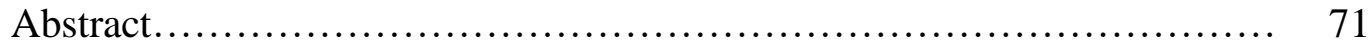

Introduction......................................................... 72

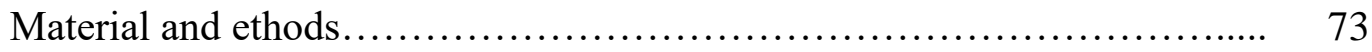

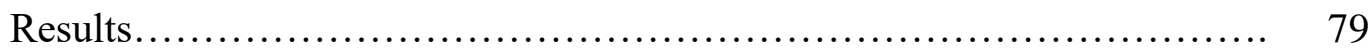

Discussion............................................................ 81

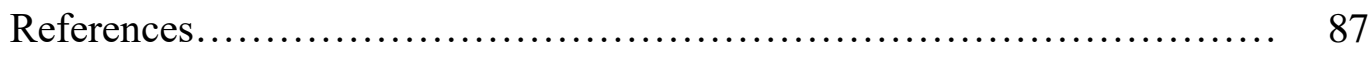

\section{CHAPTER 4}

Abstract.................................................................. 98

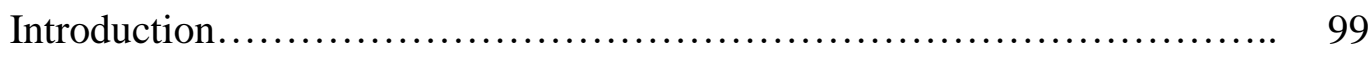

Material and Methods.............................................. 101

Results................................................................... 105

Discussion..................................................... 107

References..................................................... 112 


\section{CHAPTER 5}

Discussion......................................................... 120

References.................................................... 126

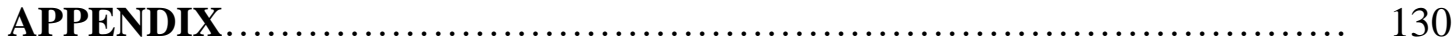




\section{LIST OF TABLES}

TABLE

PAGE

\section{CHAPTER 1}

Table. 1. Genera of microalgae commonly used in shrimp hatcheries.

Table 2. Nutritional requirements of shrimp larvae.

Table 3. Known nutrient profiles of some microalgae strains

Table 4. Optimum culture environment of some microalgae species commonly used in shrimp hatcheries

\section{CHAPTER 2}

Table 1. List of strains that were isolated in this study, isolation location, date

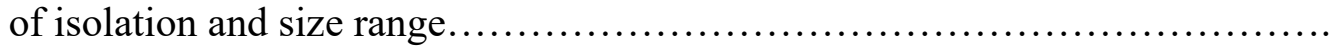

Table 2. Size ranges of cultured microalgae at each salinity tested

Table 3. Yield of cultured microalgae during stationary phase at different salinities.

Table 4. Final dry weight of microalgae.

Table 5. Size, division rate and dry weight of microalgae.

\section{CHAPTER 4}

Table 1. List of fatty acids found in Indonesian microalgae strains and T. lutea at different salinity

Table 2. Cell weight, division rate and final biomass of Indonesian microalgal strains and T. lutea 


\section{CHAPTER 3}

Table 1. Initial and final dry weight of larvae Litopenaeus vannamei fed with Indonesian microalgae strains, C. neogracile, T. lutea and Te. chui during protozoea

stages.

Table 2. Microalgal cells dry weight, final survival, percentage of weight gain after 8 days of feeding experiment, and growth rate of white shrimp larvae fed on Indonesian microalgae strains, $C$. neogracile, $T$. lutea and Te. chui during protozoea stages....................................................

Table 3. Food supplied, food ingested, weight gain, food conversion index and gross growth efficiency of individual white shrimp larvae fed four Indonesian microalgae strains and three control species........................................................ 


\section{LIST OF FIGURES}

FIGURE

PAGE

\section{CHAPTER 1}

Figure 1. Source of microalgae starter culture for hatchery operation in SE

Sulawesi

Figure 2. Typical Provi APT system for efficient microalgae culture

\section{CHAPTER 2}

Figure 1. Diagram of microalgae culture

Figure 2. Scanning electron microscopic images of microalgal isolates

Figure 3. Microphotographs of Indonesian microalgae strains

Figure 4. Increases of cell density of Indonesian isolates of microalgae compared to T. lutea, Te. chui and C. neogracile

Figure 5. Division rate of cultured microalgae during logarithmic phase of growth

\section{CHAPTER 3}

Figure 2. Proximate composition of microalgae.

Figure 3. Fatty acids distribution in Indonesian microalgae strains and $T$. lutea at different salinity

\section{CHAPTER 4}

Figure 1. Survival of the shrimp larvae over the eight-day experiment 


\title{
CHAPTER 1
}

Microalgae in Eastern Pacific White Shrimp, Litopenaeus vannamei (Boone 1931) hatcheries: A Review on Roles and Culture Environments

\author{
By \\ Wa Iba ${ }^{1,2^{*}}$, Michael A. Rice ${ }^{1}$ And Gary H. Wikfors ${ }^{3}$ \\ ${ }^{1}$ Fisheries and Aquaculture Department, University of Rhode Island, USA 126 Woodward Hall, \\ University of Rhode Island, Kingston, RI 02881. USA. \\ ${ }^{2}$ Faculty of Fisheries and Marine Science, University of Halu Oleo. \\ Kampus Hijau Bumi Tridharma Anduonohu Kendari, SE Sulawesi, 93232. Indonesia \\ ${ }^{3}$ Northeast Fisheries Science Center, NOAA Fisheries Service \\ 212 Rogers Avenue Milford, CT 06460 USA \\ *Corresponding author. E-mail address: wa_iba@my.uri.edu
}

Is published in Asian Fisheiries Science Journal

Proper citation:

Iba, W., Rice, M.A., Wikfors, G.H. 2014. Microalgae in Eastern Pacific White Shrimp, Litopenaeus vannamei (Boone 1931) hatcheries: A Review on Roles and Culture Environments. Asian Fisheries Science. 27: 212-233 


\begin{abstract}
Demand for shrimp, particularly the eastern Pacific white shrimp Litopenaeus vannamei (Boone 1931), will continue to increase in Asian and worldwide seafood markets. Providing shrimp farms with a robust, healthy, and continuous supply of shrimp seed is a challenge that must be addressed to meet the demand. Shrimp feed during hatchery production still relies on live microalgae, despite many years of effort to find suitable full- or partial-replacement diet alternatives. Successful mass production of microalgae for hatchery feed to obtain good quality shrimp seedstock depends on a number of environmental factors that determine the growth and nutritional values of various microalgal species. These factors include nutrients in the culture medium, light intensity, temperature, salinity, and $\mathrm{pH}$. An overview of the use and the culture of microalgae in shrimp hatcheries is also presented and outlines the need for research for optimisation of algal diets for the rearing of L. vannamei seedstock in Asian hatcheries. Finally, the possibilities of using local isolates for hatchery operation are also highlighted.
\end{abstract}




\section{Introduction}

Despite their critical functions in the aquaculture production chain, microalgae are not documented exhaustively compared to many other cultured organisms. FAO (2012) reported that only small quantities of microalgae are cultured for direct human consumption; this production consists of two species, Spirulina sp. and Haematococcus pluvalis J. Von Flotow 1844. These two species are cultured mainly for extraction of C-phycocyanin and astaxanthin, respectively. Borowitzka (2013) reviewed various high-value products derived from microalgae, from B-carotene and fatty acids to phycobilins and other unrevealed bioactive compounds, highlighting the potential importance of microalgal research in the future. In aquaculture, microalgal production is mainly conducted to provide live food for mollusc, shrimp, and fish culture. As the production of microalgae still is considered expensive (e.g. Walsh et al. 1987), several approaches have been attempted to replace microalgae in the hatchery with artificial diets. To date, however, microalgae still cannot be replaced fully with other types of feed, such as microbound diets and other enrichment diets such as Nutrokol, S. presso and Algamac (Gallardo et al. 2002; Sanchez et al. 2012; Ma and Qin 2012).

Research on microalgal culture since the early 1940's has led to wide use for feeding early life stages of cultured fish, shrimp, sea urchins (Conceciao et al. 2010; Carboni et al. 2012), and during the entire life cycle of cultured bivalves (Wikfors and Ohno 2001; Gonzalez-Araya et al. 2011). Microalgae are also used for growing and enriching zooplankton live feeds, such as Artemia, copepods, and rotifers (Chakraborty et al. 2010) that are fed subsequently to larval fish and shrimp. Microalgal use in the fish hatchery is known as the "green water technique" wherein microalgae are added 
directly to larval rearing tanks along with the zooplankton that serve as food for the larvae. Green-water larviculture has been shown to increase larval quality of cultured fish species (Conceicao et al. 2010; Hemaiswarya 2011; Sanchez et al. 2012). Moreover, research on nutritional requirements of molluscs has led to improved algal culture procedures, particularly with the finding that $\mathrm{f} / 2$ culture medium is suitable for various species of microalgae, both in temperate and tropical regions (Wikfors and Ohno 2001). Work showing that cost reductions can be made in mass microalgal cultures by replacing f/2 medium with less expensive agricultural fertilisers (e.g. Valenzuela-Espinoza et. al. 1999; Simental-Trinidad et al. 2001) has expanded nutrient options for microalgal mass culture.

Studies on the biochemical composition of microalgae have enabled aquaculturists to select superior species of microalgae, such as Isochrysis spp.,(some now assigned to the new genus Tisochrysis (Bendif et al. 2013), Pavlova lutheri (assigned to new name Diacronema lutheri (Droop) Bendif and Véron 2011), Navicula spp., and Chaetoceros calcitrans (Paulsen) Takano, 1968 , as food for various cultured species, including oysters, scallops, fish, and shrimp larvae (Blackburn et al. 2000; Burke 2000). Research has shown that microalgae with high contents of metabolisable sterols and essential fatty acids are desirable for aquaculture live feeds, particularly for rapid growth of oysters (Wikfors et al. 1984, 1991, 1996). Furthermore, dietary cholesterol is an essential nutrient for crustaceans as they cannot synthesise this sterol de novo, thus it or a precursor phytosterol must be supplied in the diet (Teshima 1982). Required sterols may be available naturally in microalgae, as shrimp juveniles cultured 
with phytoplankton showed better growth and survival compared to shrimp grown in a non-phytoplankton culture method (Sanchez et al. 2012).

Shrimp aquaculture has increased rapidly within the last decades, and cultured shrimp continue to dominate international seafood markets. Aquaculture contributed $52 \%$ of the shrimp supply in the world market in 2009 , reaching 3.8 million tonnes by 2010 (FAO 2012). During 2005-2009, world shrimp aquaculture production increased up to $7 \%$ annually, but decreased $3 \%$ from 2010 to 2011 , and then increased again in 2012 (FAO, 2012). It was projected that shrimp aquaculture will have increased up to 10.3\% in 2013 (Valderrama and Anderson 2012).

The eastern Pacific white shrimp, Litopenaeus vannamei (Boone 1931) is an increasingly popular and important cultured shrimp species after the decline in giant black tiger prawn (Penaeus monodon Fabricius 1798) production caused by white spot syndrome disease outbreaks world-wide, most devastatingly in Southeast Asia. As a result, the white shrimp has been introduced to most Southeast Asian countries in the past few years. Litopenaeus vannamei has been cultivated widely in Asia, North America, South America and the Pacific Islands because of high survival, rapid growth in intensive culture systems, and disease tolerance (Briggs et al. 2004). The proportional share of $L$. vannamei in global shrimp production continues to increase. Litopenaeus vannamei contributed $7 \%$ to global production in 2001 , with a net volume of 0.2 million tonnes, but in 2009 , this contribution had increased to $58 \%$, with a volume of 1.6 million tonnes. The peak production of white shrimp was in 2007 when this species accounted for $68 \%$ of global production. It was predicted that in 2013 , this 
species will have contributed up to $69 \%$ of global shrimp aquaculture production (Valderrama and Anderson 2012).

As the demand for shrimp products from both local and international markets continues to increase, supply of shrimp larvae and post larvae to farmers is necessary to meet the growing demand. Hatchery seed stock, therefore, is a critical step in the production chain that needs to be addressed, in terms of technology and husbandry protocols. A survey conducted by the Global Aquaculture Alliance in 2011 revealed that seed stock quality and availability was still the main issue limiting production of high-quality shrimp in Asia (Valderrama and Anderson 2012). Accordingly, a research programme to explore the possibility of using local microalgae isolates that meet nutritional demands in shrimp hatcheries can contribute to ensuring that hatchery protocols are conducted appropriately to rear shrimp larvae and post larvae locally as robust, healthy, and cost-effective seed stock for commercial use. Local isolates of microalgae will reduce transportation cost and may help small-scale farmers to increase productivity and thus incomes. Local culture of microalgae will also ensure a continuous supply of live feeds to aquaculture hatcheries, particularly shrimp hatcheries. Finally, a small-scale and local installation of microalgae culture is a promising solution not only to overcome hatchery feed challenges, but will also provide employment that can drive economic growth.

In terms of sustainability, producing microalgae for aquaculture is considered to be more favourable compared to other fish feed production (Taelman et al. 2013). This study found that, based on life-cycle analysis of microalgae production for aquaculture, recycling of nutrients and energy savings were identified as important ways to increase 
the sustainability of algae production. Up-scaling, reactor design improvements, enhancement of photosynthetic yield, and a good choice of location also contribute to a low resource and carbon footprint. Considering that microalgae still are an important part of shrimp hatcheries, this present review discusses the use of microalgae to feed early stages of white shrimp, as well as some environmental factors affecting the growth and nutritional content of microalgae necessary for shrimp growth and development. Therefore, the intent of this review is to provide an overview on the use of microalgae in shrimp hatcheries, particularly white shrimp and the possibilities of using local isolates for hatchery operations.

\section{Shrimp nutrition: use of microalgae in early life stages of white shrimp}

In natural environments, white shrimp larvae feed initially on phytoplankton and detritus, then on macrophytes, small molluscs, crustaceans, and zooplankton as they grow larger (Senanan et al. 2009). Microalgae are recognised widely to serve as nutritionally important live feeds for rearing shrimp in the hatchery. All nutritional components required for larval shrimp growth may be fulfilled with microalgae in the rearing tanks. Several research projects have shown that, in the culture environment, white shrimp larvae grew faster when co-cultured with phytoplankton (Gallardo et al. 2002; Sanchez et al. 2012; Ju et al. 2009; Nunes et al. 2011), underscoring the importance of microalgae in shrimp nutrition during hatchery rearing.

Approximately 16 genera of microalgae are used in aquaculture; strains used generally have a size range of $2-20 \mu \mathrm{m}$ with most of the genera being planktonic (Gopakumar and Ignatius 2006). Several genera that are used commonly in shrimp aquaculture are summarised in Table 1. The listed genera of microalgae have been 
widely used because of good nutritional profiles and ease of culture (Hemaiswarya 2011). Diatoms, particularly Thalassiosira spp. and Amphipora spp., were found to be ingested and digested readily by white shrimp juveniles (Kent et al. 2011). A cyanobacterial species, Spirulina platensis (Gomont) Geitler 1925: 344 (currently accepted name is Arthrospira platensis (Nordstedt) Gomont 1892), also was shown to play an important role in reducing nitrogen levels in black tiger shrimp rearing tanks (Chuntapa et al. 2003).

Research on other potential microalgal isolates for use in white shrimp aquaculture hatcheries will continue into the future as we explore local natural resources. For instance, local microalgae isolates from southeast (SE)-Sulawesi, Indonesia are not utilised yet, despite their potential to support aquaculture industries in the region. These local microalgae may have comparable growth rates and nutritional values to the imported counterparts isolated elsewhere in the world. Currently, shrimp aquaculture in SE-Sulawesi relies upon microalgae starters supplied from the south Sulawesi and Java regions (Fig.1) that impose high operational costs to aquaculture farms and hatcheries in the region. The price of microalgae starter culture obtained from Java and south Sulawesi such as Spirulina sp., Chorella, and Dunaliella, is in the range of US\$10-30 $\mathrm{L}^{-1}$. That price can be reduced up to $50 \%$ if the starter culture were to be provided within SE-Sulawesi region. Importing microalgae from other regions also increases greenhouse gas (GHG) emissions associated with air and ground transportation (Edwards-Jones 2010) and exposes receiving areas to risks from nonnative species invasions, including both the algae themselves and any contaminating microorganisms. To reduce both cost and non-native introduction issues, the use of 
locally-isolated, cultured microalgae in local hatcheries may be considered. Locallyisolated microalgae with good growth and complete nutritional profiles will help small farmers to increase the productivity of their farms and thus their incomes, which is beneficial to drive economic growth.

We have isolated four strains of local microalgae from Kendari Bay, SESulawesi. Those strains are noted as Kb1-2, Kb1-3, Kb1-5 and Kb2-6 identified as Melosira moniliformis (O.F.Müller) C.Agardh 1824. Growth experiments on these strains have been conducted in the Coastal Institute, University of Rhode Island. We found that the growth and biomass of these isolates, particularly the Kb1-3 strain, is comparable to Chaetoceros neogracile S.L. Vanlandingingham 1968 and Thalassiosira weissflogii (Grunow) G. Fryxell\& Hasle 1977 at high salinity (35 psu). We are now examining the nutritional content of these strains and identifying the strain using scanning electron microscopy before conducting feeding trials with white shrimp post larvae. These preliminary results suggested that local isolates may have potential for use in shrimp hatcheries, assuming the nutritional compositions of the algae are appropriate. Several studies have been conducted to analyse the nutritional composition of locally isolated microalgae that may be used for tropical aquaculture, e.g., Renaud et al. (1999), Nunez et al. (2002) and Martinez-Fernandez et al. (2006). Renaud et al. (1999) screened 18 strains of local microalgae from tropical waters of Australia and suggested that they may be used for mariculture. Similarly, a study by Nunez et al. (2002) tested the efficacy of employing local isolates of microalgae from north-eastern Venezuela as feed for white shrimp post larvae. They found that local isolates can be utilised by shrimp post larvae. Moreover, shrimp grew better and produced higher 
biomass under local conditions at large scale production, thereby reducing the production cost.

As is true for other cultured animals, shrimp require sufficient levels of proteins, lipids, carbohydrates, minerals, and vitamins for normal growth and development. Nutritional requirements of shrimp larvae and juveniles were reviewed by Kanazawa (1982). Diatoms and brine shrimp have been used commonly for shrimp larval rearing in the hatchery with good results. Shrimp such as Penaeus japonicus Spence Bate 1888 need proteins and essential amino acids, with an optimum dietary protein level of 5257\% (Kanazawa 1982). Protein in microalgae is considered to be of good quality, with amino acid profiles comparable to those of other reference food proteins (Gallardo et al. 2002). This may be the reason why shrimp larvae exhibited poor growth when cultured using only a micro-bound diet without microalgae, although Pedroza-Islas et al. (2004) found that a microencapsulated diet with a wall composition of a polysaccharide blend could be used to rear white shrimp mysids. Protein contents of microalgae vary between species and range from $12 \%$ to $35 \%$, and this value is influenced by culture medium (Becker 2004). In general, microalgae can be considered to be a good candidate for shrimp aquaculture if they contain a protein higher than $25 \%$ of dry weight, $8-30 \%$ carbohydrate, and approximately $10 \%$ lipid , specially including certain types of lipids such as the fatty acids $C 20: 5 \omega 3$ and $C 22: 6 \omega 3$ (Nunez et al. 2002). We summarised the nutritional requirement of shrimp and microalgal strains/species that produce these nutrients in Table 2 and 3.

Carbohydrates are utilised by shrimp larvae and juveniles in the form of disaccharides such as sucrose, maltose, and trehalose, and polysaccharides, such as 
dextrin and starch (Kanazawa 1981). A study with P. japonicus juveniles by Kanazawa (1981) showed that maltose was much more readily utilised as an energy source than other sugars. Unlike dietary glucose, that is not converted to trehalose but quickly absorbed from the stomach and released to the blood, maltose is not absorbed from the stomach. Instead, this disaccharide is converted to glucose in the mid gut, then to trehalose in the hepatopancreas, and is finally released gradually into the blood. High variation is found in carbohydrate contents of microalgae, which ranged from $4.6 \%$ to 23\% (Wikfors and Ohno 2001). This variation is determined by culture procedures employed (Ferreira et al. 2009). Carbohydrate content in Nannochloropsis gaditana L.M. Lubián 1982 decreased from $28.47 \%$ to $21.01 \%$ when this species was grown in semi-continuous culture with daily renewal rates of $10 \%$ or $50 \%$, respectively.

Shrimp have been shown to have special needs in lipid metabolism. Fatty acids (FAs) are organic molecules typically found bound to other compounds such as glycerol, sugars, or phosphate head groups to form lipids. Lipids are integral components of cell structures, e.g. membranes, which are made up of phospholipids, and energy stores that often are composed of triglycerides. Through enzyme reactions, FAs can be released from lipids to become free fatty acids (FFAs). The biological activities of FFAs have roles in host defence against potential pathogenic or opportunistic microorganisms, e.g., growth inhibition or the direct killing of bacteria (Desbois and Smith 2010). Shrimp fed on mixtures of formulated and natural feed may have better immunological and nutritional condition when compared to those fed on formulated feed alone because of the greater amount of essential amino acids, fatty acids 
(Poly Unsaturated Fatty Acids/PUFA and Highly Unsaturated Fatty Acids/HUFA), and other nutritional factors supplied by the live feed component.

Penaeid larvae have an absolute requirement for long-chain, polyunsaturated fatty acids, especially for C20 and C22: $₫-3$ and $₫-6$ compounds. In particular, shrimp growth seems to be promoted by docosahexaenoic acid (DHA) 22:6ø-3 and enhanced further by eicosapentaenoic acid (EPA) 20:5ळ-3 (Castell 1982). Growth rates of protozoeal stages of Penaeus semisulcatus De Haan 1844, P. monodon, and $P$. japonicus can be enhanced by dietary supplementation with 20:4®-6 arachidonic acid (ARA) (D'Souza and Loneragan, 1999). Deficiencies in the $₫-3$ HUFA contents of microalgae may cause mortalities and/or quality problems in shrimp. Measurable concentrations of EPA generally are present in diatom species ( $C$. calcitrans, $C$. neogracile, Skeletonema costatum (Greville) Cleve 1873 and Thalassiosira pseudonana Hasle \& Heimdal 1970 ), as well as in Nannochloropsis sp., Tetraselmis suecica (Kylin) Butcher 1959, Tetraselmis chui Butcher 1959, and "Chlorella minutissima Fott \& Nováková 1969” (in reality, a eustigmatophyte) (Brown 1997; Becker 2004).

Cholesterol is an essential nutrient that must be supplied in the diet of shrimp, directly or as a precursor, because crustaceans cannot synthesise this compound de novo (Teshima 1981). Cholesterol is the main sterol found in crustaceans and is required for normal development, survival, and growth. Cholesterol also is a precursor for sex hormones, molting hormones, and epidermis constituents in crustaceans (Lim 1998). Sterol content has been investigated by Gladu et al. (1991) for diatom species. These researchers found that five of seven diatom species (T. pseudonana, T. weisflogii, Detonula confervacea (Cleve) Gran 1900, Cyclotella cryptica Reimann, Lewin \& 
Guillard and Nitzschia brevirostris Hustedt examined in the study contained 24methylenecholesterol and 24-methylcholesterol, which together made up 63-97\% of the total sterols of these species. Moreover, stigmasterol was the principal sterol in Amphora coffaeformis (C. Agardh) Kützing 1844 (currently accepted name is Halamphora coffeaeformis (Agardh) Levkov 2009), and 24-ethylcholesterol was the major sterol in Navicula pelliculosa Hilse 1863: 68 (currently accepted name is Fistulifera pelliculosa (Brébisson) Lange-Bertalot 1997). Although cholesterol is not the predominant phytosterol, some phytosterols can partially substitute for cholesterol in the shrimp diet (Teshima 1981; Lim 1998).

Crustaceans, such as shrimp, absorb minerals from water but also need minerals and vitamins included in their diets. Kanazawa (1981) stated that mineral dietary supplement in shrimp is required as these compounds are lost in molted exoskeletons. Vitamin content is a major factor determining the nutritional value of microalgae. The microalgae showing relatively high concentrations of different vitamins were: $T$. suecica for thiamin, pyridoxin, nicotinic acid, pantothenic acid and ascorbic acid and Chlorella stigmatophora Butcher for vitamin A, tocopherol (vitamin E) and biotin (Fabregas and Herrero 1990). Some strains of Dunaliella such as Dunaliella tertiolecta Butcher, 1959 and Dunaliella salina (Dunal) Teodoresco, 1905 have been known to be a good source of $\beta$-carotene, riboflavin, cobalamin and folic acid and thus been exploited since 1980s for human consumption and aquaculture (Fabregas and Herrero 1990; Raja et al. 2007; Abu Rezq et al. 2010; Borowitzka 2013). Tisochrysis iso (revised to Tisochrysis lutea El M.Bendif and I. Probert as in Bendif et al. 2013) and Isochrysis spp., also is a good source of fat-soluble vitamins (vitamin A and vitamin E, 
biotin, ascorbic acid, and B-group vitamins (folic acid, nicotinic acid, pantothenic acid, biotin, thiamin, riboflavin, pyridoxine and cobalamin) (Coutinho et al. 2006).

\section{Microalgal isolation and production techniques}

\section{Isolation and culture systems}

Although several isolated microalgae species are readily available for aquaculture from research centres or large hatcheries, locally-isolated species may be preferred for local use to reduce transportation cost and assure constant availability. Successful isolation of specific microalgae from the local environment is determined by some important factors, including: environmental conditions (water quality of natural samples are thought to be controlled by habitat conditions and sampling time), taxonomic knowledge (to determine nutrients for culture of isolated species) and elimination of contaminants. Andersen and Kawachi (2011) suggested using caution and multiple methods to isolate unknown species. Microalgal isolation methods commonly used are: enrichment culture, single cell isolation by micropipette, agar isolation, dilution, gravity separation, and phototaxis techniques.

Enrichment culture is the most common culture and isolation method for microalgae; microalgae are induced to "bloom" by fertilisation (addition of nutrients to the water sample). Adding nutrients to the natural water samples is important to overcome possible nutrient deficiencies. Enrichment with nutrients is necessary, as the natural samples often are deficient in one or more nutrients. Microalgae survive in nature because of recycling processes making nutrients continually available in small quantities. Nutrients required for microalgal growth include the macronutrients nitrate or ammonia and phosphate (in an approximate ratio of 16:1), silicate (if growing 
diatoms), and micronutrients, including various trace metals and the vitamins thiamin $\left(\mathrm{B}_{1}\right)$, cyanocobalamin $\left(\mathrm{B}_{12}\right)$ and sometimes biotin. These nutrients usually are mixed together in specific proportions to create microalgal culture medium (including formulations sold commercially). Walne medium and f/2 medium are the two most extensively used enrichment media and are suitable for the growth of most algae. There are also commercially-available nutrient solutions that are suitable for mass production of microalgae in large-scale, extensive systems. These solutions contain only the most important nutrients and are made of agriculture-grade fertilisers rather than laboratorygrade reagents. These culture media, sometimes together with aqueous soil extract, are the most common enrichment substances for growing microalgae (Andersen and Kawachi, 2011). Generally the amount of nutrients to be added to seawater must be moderate to avoid detrimental effects.

Hemaiswarya (2011) summarised some factors to be considered for production of microalgae, including: the biology of the alga; cost of land, labour, energy, water, and nutrients (climate if the culture is outdoors); and the type of final product needed. Microalgal production remains the main bottleneck to assuring the continuous supply of live feed to shrimp hatcheries. According to Enzing et al. (2014), several factors need to be addressed within 4 to 5 years to achieve the stability of microalgal feed production: 1) lowering the production costs of feed, 2) improvement of production technologies for the safety of food products, 3) stability/reliability of large cultures, 4) suitable strains, and 5) avoiding contamination and subsequent failure of the cultures. Using local isolates for shrimp aquaculture, as suggested earlier in this review, could become a solution to reduce the production cost and prevent contamination of foreign strains, 
bacteria, and parasites. Furthermore, local microalgae tend to grow better under local environment conditions, thus reducing the risk of culture crash and would be eaiser to maintain in small scale hatcheries as suggested by Cotteau (1996) and Nuñez (2002).

Culture of microalgae for aquaculture purposes (rearing of molluscs, shrimp, and fish larvae) takes place mostly on-site, i.e., in the farms where they are utilised, although a new industry is emerging for the production of microalgae and delivery in lyophilised, frozen, or other forms to the farms (Navarro and Sarasquete 1998; Muller-Fuega 2004). Once in farms, stock cultures are kept under controlled conditions and protected from contamination by other microalgae, ciliates, and potentially harmful bacteria. Bags and cylindrical tanks are quite common approaches for the mass-production of microalgae on farms. In many parts of the world, however, particularly in Southeast Asia, facilities at the farm level are lacking and insufficient. Purchasing healthy seed from a local hatchery that utilises local microalgae would be one solution to reduce the production cost of farmers in developing countries.

Various techniques have been developed to grow microalgae on a large scale, ranging from less-controlled and extensive to mono-specific, intensive cultures. The controlled production of microalgae, however, still is a complex and expensive procedure. Semi-continuous and continuous cultures are commonly used in microalgal production in the hatchery. Semi-continuous culture, in which a percentage of the volume of the culture is harvested periodically and replaced with the same amount of fresh culture medium, is considerably easier and cheaper to establish. Semi-continuous culture management also produces microalgal biomass with high nutritional values (Ferreira et al. 2011). 
Based on the intensity of the culture and average cell density from low to high, microalgae culture technology is divided into several types of containers: earth ponds, raceways, plastic polyethylene bags (100-500 L), open cylindrical tanks constructed of polymer fibre glass, and tubular and flat-plate photo-bioreactors. Earth ponds and raceways are more open systems, inexpensive, exposed to weather conditions, and more prone to contamination. In addition, the cell density remains at relatively low levels in comparison with the other culture systems. On the other hand, closed systems are much more expensive to operate, although they can produce high yields of microalgal biomass. Taelman et al. (2013) suggested that the closed photobioreactor for aquaculture purposes will be more profitable and produce higher biomass of microalgae if the design is improved, such as those of Provi APT (Proviron Advanced Photobioreactor Technology) (Fig. 2).

This system basically contains a plastic bag $\left(12 \mathrm{~m}^{2}\right)$ filled with water and placed on the ground. Each bag contains 35 embedded plastic panels in which the algae grow, yielding a reactive surface of $7 \mathrm{~m}^{2}$. The Provi APT system is inexpensive to build as it consists entirely of plastic, and automated production can be employed. This design of photobioreactor has been used in trials to culture Nannochloropsis sp., which produced approximately 17 tonnes of dried algal biomass per hectare annually (Taelman et al. 2013). This kind of system can be developed on a smaller scale at hatchery level to protect the culture from contamination, to maintain the nutritional value, and also to ensure continuous supply. 


\section{Culture conditions and nutritional values}

Culturing microalgae under optimal conditions is advantageous to achieve high nutritional values that are beneficial for shrimp larvae. Among other things, light intensity, day length, and nutrient concentrations are important factors regulating microalgae growth in culture and also affect the nutritional content (Renaud et al. 1991; Lewis et al. 2002; Meseck et al. 2005; Sheng et al. 2011; Huang et al. 2013). Several researchers also have shown that salinity, $\mathrm{pH}$, and temperature are important factors determining the growth of microalgae and controlling the nutritional quality (Goldman et al. 1982; Schmidt and Hansen 2001; Lewis et al. 2002; Renaud et al. 2002; Khatoon

et al. 2010; Gu et al. 2012). Table 4 summarises the optimal culture condition for microalgae species commonly used in shrimp aquaculture.

Microalgae most fundamentally need light (intensity and period) for photosynthesis. They need light for a photochemical phase of the photosynthetic process to produce Adenosine triphosphate (ATP), Nicotinamide adenine dinucleotide phosphate-oxidase (NADPH), and use dark periods for biochemical phases synthesising essential molecules for growth (Cheirsilp and Torpee 2012). In the natural environment, microalgae utilise readily available sunlight easily. In controlled, indoor culture conditions, it is difficult to rely upon natural sunlight alone because of seasonal variability. The most common tool to provide illumination in indoor conditions is the fluorescent lamp. Optimal photoperiod to grow microalgae depends upon the place and season. The 12:12 h (light: dark) period may be appropriate to employ in the tropics, but in temperate regions, a 16:8 h photoperiod may result in better microalgal growth. A study by Harrison et al. (1990) found that light intensity at $300 \mu \mathrm{mol}$ photon $\mathrm{m}^{-2} \mathrm{~s}^{-1}$ 
PAR was optimal for growth of Isochrysis galbana Parke 1949, T. pseudonana and C. calcitrans. Moreover, the study found that no consistent trend was observed in lipid content of those three microalgae under light limitation (less than $300 \mu$ mol photon $\mathrm{m}^{-2} \mathrm{~s}^{-1} \mathrm{PAR}$ ), and protein content was relatively constant for I. galbana and $T$. pseudonana, but decreased in C. calcitrans with lower illumination. However, a study by Renaud et al. (1991) found high light intensity in culturing Isochrysis sp and Nannochloropsis oculata (Droop) D.J.Hibberd 1981 decreased the ratio of total unsaturated fatty acids to total saturated fatty acids. A recent study by Khoeyi et al. (2012) noted that the maximum biomass of Chlorella vulgaris Beyerinck (Beijerinck) 1890 was recorded between $0.1 \mathrm{~g}$ and $2.05 \mathrm{gL}^{-1}$ when the culture was exposed to 62.5 $\mu$ mol photon $\mathrm{m}^{-2} \mathrm{~s}^{-1} \mathrm{PAR}$ for a 16:8 $\mathrm{h}$ light/dark photoperiod; whereas, the maximum percentage of total saturated fatty acids (SFA) was $33.38 \%$ at $100 \mu$ mol photon $\mathrm{m}^{-2} \mathrm{~s}^{-1}$ PAR on a 16:8 h light/dark photoperiod. Other microalgae that are not popular for aquaculture, such as Lobosphaera incisa (Reisigl) Karsten, Friedl, Schumannn, Hoyer \& Lembcke 2005, showed that at high light intensity ( $400 \mu$ mol photon $\left.\mathrm{m}^{-2} \mathrm{~s}^{-1} \mathrm{PAR}\right)$ and complete nutrient culture medium, the cells exhibited higher growth rates and high contents of total fatty acid and arachinoid acid compared to medium $(200 \mu \mathrm{mol}$ photon $\mathrm{m}^{-2} \mathrm{~s}^{-1} \mathrm{PAR}$ ) and low (35 $\mu \mathrm{mol}$ photon $\mathrm{m}^{-2} \mathrm{~s}^{-1} \mathrm{PAR}$ ) light intensity (Solovchenko et al. 2008). For long-term culturing of most microalgal species, light intensity at 10-30 $\mu$ mol photon $\mathrm{m}^{-2} \mathrm{~s}^{-1} \mathrm{PAR}$ and low temperature $\left(15^{\circ} \mathrm{C}\right)$ have proven to be reliable to keep cultures alive with minimal subculturing (Lorenz et al. 2011).

Nutrient enrichment also controls the growth, protein, carbohydrate, lipid, and fatty acid composition of microalgae. Sheng et al. (2011) showed that, in a P-depleted 
treatment (f/2-P), the cell size of $T$. weissflogii was 1.48 times larger than that in the full-nutrient-limited (f/100) treatment and 2.67 times larger than that in P-saturated treatments ( $\mathrm{f} / 2$ and $\mathrm{f} / 10)$. Silica is necessary for optimal growth of diatoms and directly affects nutritional contents (Kröger et al. 1999; Ponomorenko et al. 2004; Sumper and Bunner 2006; Schwenk et al. 2013). Although Harrison et al. (1990) found that carbohydrate, lipid, and protein contents of I. galbana, T. pseudonana and C. calcitrans were not changed under $6 \mathrm{~h}$ silica $(\mathrm{Si})$ starvation, providing silica in the culture medium is necessary for rapid growth of any diatom (Sumper and Bunner 2006; Schwenk et al. 2013). Moreover, the study by Harrison et al. (1990) also found that, under 2 days of nitrogen $(\mathrm{N})$ starvation, does not change the cellular lipid percentage, but the protein percentage decreased, and the carbohydrate percentage increased. Solovchenko et al. (2008) showed that $L$. insica cultured in nitrogen- depleted medium contained increased arachidonic acid as a percentage of total fatty acids. Moreover, Huang et al. (2013) showed that the total lipid content, as well as the proportions of neutral lipid, in Tetraselmis subcordiformis (Wille) Butcher 1959 SHOU-S05, Nannochloropsis oculata (Droop) D.J.Hibberd 1981 SHOU-S14 and Pavlova viridis C.K. Tseng, J. Chen \& X. Zhang 1991 (currently accepted name is Diacronema viridis (C.K.Tseng, Chen and Zhang) Bendif and Véron 2011) SHOU-S16, decreased significantly with increasing nitrogen supplementation. Eicosapentaenoic acid (EPA (20:5ø3)) and C16 fatty acids were significantly higher in $N$. oculata and D. viridis, respectively with increased nitrogen enrichment. This study also showed that N.oculata and D. viridis accumulated more 16-carbon fatty acids and fewer polyunsaturated fatty acids in nitrogen-limited media. Schwenk et al. (2013) revealed that lipid content of several 
species of microalgae, including I. galbana, Chaetoceros muelleri Lemmermann 1898 and $T$. pseudonana, increased during early stationary phase as the nitrogenlimited environment shifted the energy supporting cell division to fatty acid biosynthesis and lipid accumulation. These findings imply that knowing growth phase (stationary or log phase) when harvesting microalgae is necessary to select the desired nutritional content of log-phase cells or stationary-phase cells that are either nutrient or light limited.

Salinity is another primary factor influencing the growth and biochemical composition of microalgae. For the purpose of this review, the standard unit for salinity is set to psu (Practical Salinity Unit), although literature has reported salinity in different units such as g.L ${ }^{-1}$ and $\mathrm{mM}$. The gross chemical and fatty acid compositions of Isochrysis sp., N. oculata, and Nitzschia sp. were significantly different at different salinities (Renaud et al. 1992). Khatoon et al. (2010) reported experiments with marine diatoms (Amphora sp., Navicula sp. and Cymbella sp.) and a cyanobacterium (Oscillatoria sp.) at different salinities. Diatom growth was significantly higher at 35 psu than at lower salinity, but cyanobacterial growth was better at $25 \mathrm{psu}$. As for protein and lipid, significantly higher quantities were found in diatoms cultured at low salinities (15-25 psu), and an increase in carbohydrate was seen at high salinities (30-35 psu). Conversely, the cyanobacterium showed a significantly higher lipid content at 30-35 psu compared with other salinity levels, but no significant changes were observed in the protein and carbohydrate contents at different salinity levels. de Castro Araujo and Tavano Garcia (2005) showed that, at high salinity (35 psu), carbohydrates were enhanced, but lipids and protein decreased in Chaetoceros cf. wighamii Brightwell 
1856 . Rao et al. (2007) found that growth of Botryococcus braunii Kützing 1849: 892 (race 'A') and its biochemical composition, i.e. hydrocarbon, carbohydrate, fatty acid, and carotenoids, were influenced by salinity. Under salinity of $34 \mathrm{mM} \mathrm{(2} \mathrm{psu)} \mathrm{and} 85$ $\mathrm{mM}$ (5 psu), a 1.7-2.25-fold increase in the relative proportion of palmitic acid, and a two-fold increase in oleic acid, were observed. A two-fold increase in carotenoid content was detected at $85 \mathrm{mM}$ (5 psu) salinity with lutein (75\% of total carotenoid) as the major carotenoid followed by $ß$-carotene.

Another important factor affecting the growth and biochemical composition of microalgae is temperature. Temperature strongly influences cellular chemical composition, the uptake of nutrients, carbon dioxide fixation, and the growth rates for every species of algae. It is known that the growth rate will increase with temperature up to a maximal level. Above this temperature, growth rate decreases drastically (Raven and Geiden 1988). Temperature tolerance in microalgae is species-specific. Renaud et al. (2002) reported that the optimum temperature for growth of Rhodomonas sp. was $25-27{ }^{\circ} \mathrm{C}$, but was $27-30{ }^{\circ} \mathrm{C}$ for a prymnesiophyte NT19. Furthermore, Cryptomonas sp., Chaetoceros sp. and Isochrysis sp. grew well at 33 and $35{ }^{\circ} \mathrm{C}$. All species had significantly lower percentages of protein when grown at temperatures above $27^{\circ} \mathrm{C}$, but there was no consistent trend in the percentages of carbohydrate. Chaetoceros sp. had the highest percentage of lipid when cells were cultured at $25^{\circ} \mathrm{C}$, but Rhodomonas sp., Cryptomonas sp., NT19, and Isochrysis sp., had significantly higher amounts of lipid at temperatures within the range $27-30{ }^{\circ} \mathrm{C}$. The highly unsaturated fatty acid (HUFA), eicosapentaenoic acid, 20:5ø3, was present in all species, with highest amounts in the prymnesiophyte NT19 (19.9\% total fatty acids). 
Percentages of 20:5ø3 were slightly lower at highest growth temperatures for all species. All species had lower percentages of 22:6®3 at higher growth temperatures. Chaetoceros sp. and NT19 had moderate amounts of arachidonic acid, 20:4ø6 in the fatty acid profile (2.7-5.4\% of total fatty acids). Highest arachidonic acid percentages were associated with growth temperatures within the range $27-30^{\circ} \mathrm{C}$. Only Chaetoceros sp. grew well at $35^{\circ} \mathrm{C}$, maintaining moderate percentages of protein, carbohydrate, lipid, PUFA, and HUFA (9.6\% total fatty acids).

The optimum temperature for $C$. vulgaris ranges from 25 to $30{ }^{\circ} \mathrm{C}$. (Sanchez et al. 2008). Several researchers have shown that biomass content, lipid, and fatty acid decreased when the culture conditions were changed from the optimal temperature range. Chinnasamy et al. (2009) reported an increase in biomass content and in chlorophyll content of Chlorella sp. at the optimum temperature $\left(30^{\circ} \mathrm{C}\right)$. Converti et al. (2009) reported that lipid content of this species increased from 5.9 to $14.7 \%$ when the temperature decreased from $30^{\circ} \mathrm{C}$ to $25^{\circ} \mathrm{C}$; at temperatures above $38^{\circ} \mathrm{C}$, oleic acid, a monounsaturated omega-9 fatty acid, production increased.

The optimum temperature to grow Scenedesmus sp. is between $20-40{ }^{\circ} \mathrm{C}$ (Sanchez et al. 2008). Previously, Christov et al. (2001) studied Scenedesmus sp. at temperatures of $15-36{ }^{\circ} \mathrm{C}$ and found that, at lower temperatures the chlorophyll and protein levels were reduced, but levels of carotenoids, saccharides, and lipid were increased. These authors also observed an increase of $30 \%$ in sugars and lipids at extremely high temperature $\left(36^{\circ} \mathrm{C}\right)$. 


\section{Conclusions}

As the demand for white shrimp products in world markets continues to increase, the continuous supply of healthy, inexpensive, and robust shrimp seed stocks to the farmers is important to maintain production of adult shrimp. Microalgae remain an important component of the aquaculture production chain, particularly for hatchery white shrimp feed, despite expensive culture installation and high production cost. Several studies and experiments have been conducted to replace the use of microalgae in white shrimp hatcheries, but to date research has showed that microalgae cannot be replaced completely. Partial substitution with other, low-price enrichment compounds and micro-bound diets is possible, but microalgae must be provided in the shrimp rearing tanks. Semi-continuous culture of microalgae, in which a portion of the biomass is harvested periodically, and nutrient medium is replaced at a constant level, is still the most-efficient procedure to be employed in shrimp hatcheries. Inexpensive outdoor culture installations may also be sufficient to supply microalgae to the hatcheries. In addition, smaller scale, inexpensive design photobioreactors may be installed at the hatchery level to minimize culture contamination, to maintain nutritional profiles, and to ensure continuous supply.

Adequate nutrients, light (intensity and period), salinity, and temperature are important factors in determining maximal growth and high nutritional value of microalgae. Readily available $\mathrm{f} / 2$ and Walne medium are the most common culture enrichments with sufficient nutrients to support growth of most algal species. The photoperiod of 12:12 h (light:dark) is suitable for culturing microalgae in the tropics, but in temperate areas a photoperiod of 16:8 generally is more favourable for growth 
and nutritional content of microalgae. Salinity and temperature optimal levels for culturing microalgae are species specific. Knowledge about log and stationary phase during the culture period is important to ensure that microalgae are harvested when they have the desired nutritional contents.

Although there are approximately 5 genera of microalgae known to serve as good quality feed sources in white shrimp hatcheries, more research on other potential microalgal strains is recommended. This is mainly driven by the concern over sustainability and productivity of local farms. Using local microalgal isolates for white shrimp production will reduce the production cost to farmers, reduce the potential negative impact of shrimp farming on the environment, and increase the dependability and productivity of the farms to the benefit of local economies. 


\section{References}

Abu-Rezq, T.S., F. Al-Hooti, D. Jacob, M. Al-Shamali, A. Ahmed and N. Ahmed. 2010. Induction and extraction of $\beta$-carotene from the locally isolated Dunaliella salina. Journal of Algal Biomass 1:58-83.

Andersen, R.A. and M. Kawachi. 2011. Traditional microalgae isolation techniques. In: Algal Culturing Techniques (ed. R.A. Andersen), pp 83-100. Elsevier Academic Press and Phycological Society of America. Massachusetts, USA.

Becker, E.W. 2004. Microalgae for aquaculture. The nutritional value of microalgae for aquaculture. In: Handbook of Microalgal Culture. Biotechnology and Applied Phycology. (ed. A. Richmond), pp. 380-391. Blackwell Science, Ames, IA, USA.

Bendif, E.M., I. Probert, D.C. Schroeder and C. de Vargas. 2013. On the description of Tisochrysis lutea gen. nov. sp. nov. and Isochrysis nuda sp. nov. in the Isochrysidales, and the transfer of Dicrateria to the Prymnesiales (Haptophyta). Journal of Applied Phycology 25:1763-1776.

Blackburn, S., C. Johnston and D. Frampton. 2000. Microalgae for aquaculture, biotechnology and the environment. In: Hatchery Feeds: Proceedings of a workshop held in Cairns. (eds. D. McKinnon, M. Rimmer and S. Kolkovski), pp 9-13. Cairns, Australia.

Borowitzka, M.A. 2013. High-value products from microalgae-their development and commercialization. Journal of Applied Phycology 25:743-756.

Briggs, M., S. Funge-Smith, R. Subasinghe and M. Phillips. 2004. Introductions and movement of Penaeus vannamei and Penaeus stylirostris in Asia and the Pacific. RAP publication 2004/10. Food and Agriculture Organization of the United Nations, Regional Office for Asia and the Pacific, Bangkok. $82 \mathrm{pp}$.

Brown, M.R., S.W Jeffrey, J.K. Volkman and G.A. Dunstan. 1997. Nutritional properties of microalgae for mariculture. Aquaculture 151:315-331.

Burke, M. 2000. Marine fingerling production at the Bribie Island Aquaculture Research centre. Intensive Green water culture: A historical perspective. In: Hatchery Feeds: Proceedings of a workshop held in Cairns (eds. D. McKinnon, M. Rimmer and S. Kolkovski), pp 19-21. Cairns, Australia.

Carboni, S., J. Vignier, M. Chiantore, D.R. Tocher and H. Migaud. 2012. Effects of dietary microalgae on growth, survival and fatty acid composition of sea urchin Paracentrotus lividus throughout larval development. Aquaculture 324-325:250258. 
Castell, J.D. 1982. Fatty acid metabolism in crustceans. In: Biochemical and Physiological Approaches to Shellfish Nutrition. Proceedings of the 2nd International Conference on Aquaculture Nutrition October 27-29 at Lewes/Rehoboth Beach, Delaware (eds. G.D. Pruder, C. Langdon and D. Conklin), pp 124-145. Lousiana State University. Baton Rouge, Lousiana.

Castille, F., A. Lawrence, P. Buisman and R. Drost. 2004. Effects of sterol supplements (Cholesterol FG, Cholesterol SF and Sterol M1M) on growth and survival of the shrimp, Litopenaeus vannamei Boone. In: Avances en nutrition Acuicola VII. Memorial des Simposium Internacional de Nutrition Acuicola. 16-19 Noviembre, 2004 (eds. L.E. Cruz Suarez, D. Ricque Marie, M.G. Nieoto- Lopez, D. Villareal, U. Schloz and M. Gonzalez), pp. 504-517. Hermosillo, Sonora. Mexico

Chinnasamy, S., B. Ramakrishnan, A. Bhatnagar and K. C Das. 2009. Biomass Production Potential of a Wastewater Alga Chlorella vulgaris ARC 1 under Elevated Levels of $\mathrm{CO} 2$ and Temperature. International Journal of Molecular Sciences 10:518-532.

Chakraborty, K., R.D. Chakraborty, E.V. Radhakrishnan and K.K. Vijayan. 2010. Fatty acid profiles of spiny lobster (Panulirus homarus) phyllosoma fed enriched Artemia. Aquaculture Research 41:e393- e403.

Cheirsilp, B and S. Torpee. 2012. Enhanced growth and lipid production of microalgae under mixotrophic culture condition: Effect of light intensity, glucose concentration and fed-batch cultivation. Bioresource Technology 110:510-516.

Christov, C., I. Pouneva, M. Bozhkova, T. Toncheva, S. Fournadzieva and T. Zafirova. 2001. Influence of Temperature and Methyl Jasmonate on Scenedesmus incrassulatus. Biologia Plantarum 44:367-371.

Chuntapa, B., S. Powtongsook, and P. Menasveta. 2003. Water quality control using Spirulina platensis in shrimp culture tanks. Aquaculture 220:355-366.

Conceicao, L.E.C., M. Yufera, P. Makridis, S. Morais and M.T. Dinis. 2010. Live feeds for early stages of fish rearing. Aquaculture Research: 41:613-640.

Coutteau, P. 1996. Microalage. In Manual on the production and use of live food in aquaculture. FAO Technical paper no 361. Lavens, P., Sorgeloos, P (eds). FAO Rome, Italy. pp 7-48.

Coutinho, P., P. Rema, A. Otero, A. Pereira and J. Fabregas. 2006. Use of biomass of the marine microalga Isochrysis galbana in the nutrition of goldfish (Carassius auratus) larvae as source of protein and vitamins. Aquaculture Research 37:793798. 
Converti, A., A.A. Casazza, E.Y. Ortiz, P. Perego and M. Del Borghi. 2009. Effect of temperature and nitrogen concentration on the growth and lipid content of Nannochloropsis oculata and Chlorella vulgaris for biodiesel production. Chemical Engineering Processing 48:1146-1151.

de Castro Araujo, S and V.N. Tavano Garcia. 2005. Growth and biochemical composition of the diatom Chaetoceros cf.wighamii brightwell under different temperature, salinity and carbon dioxide levels. I. Protein, carbohydrates and lipids. Aquaculture 246:405-412.

Desbois, A.P and V.J. Smith. 2010. Antibacterial free fatty acids: activities, mechanisms of action and biotechnological potential. Applied Microbiology and Biotechnology 85:1629-1642.

D'Souza, F.M.L and N.R Loneragan. 1999. Effects of mono specific and mixed algal diets on survival, development and fatty acid composition of penaied prawn (Penaeus sp) larvae. Marine Biology 133:621-633.

Edwards-Jones, G. 2010. Does eating local food reduce the environmental impact of food production and enhance consumer health? Symposium on 'Food supply and quality in a climate-changed world'. Proceedings of the Nutrition Society 69:582591.

Enzing, C., M. Ploeg, M. Barbosa and L. Sijtsma. 2014. Microalgae-based products for the food and feed sector: an outlook for Europe (eds. M. Vigani, C. Parisi and E. R. Cerezo). JRC Scientific And Policy Reports. European Commission Joint Research Centre. Institute for Prospective Technological Studies. Seville. Spain. $82 \mathrm{pp}$.

FAO. 2012. The State of World Fisheries and Aquaculture 2012. Food and Agriculture Organization of the United Nations. Rome, Italy. 209 pp.

Fabregas, J and C. Herrero. 1990. Vitamin content of four marine microalgae. Potential use as source of vitamins in nutrition. Journal of Industrial Microbiology 5:259-264.

Ferreira, M., P. Coutinho, P. Seixas, J. Fabregas and A. Otero. 2009. Enriching rotifers with "premium" microalgae Nannochloropsis gaditana. Marine Biotechnology 11:585-595.

Ferreira, M., P. Seixas, P. Coutinho, J. Fábregas and A. Otero. 2011. Effect of the Nutritional Status of Semi-continuous Microalgal Cultures on the Productivity and Biochemical Composition of Brachionus plicatilis. Marine Biotechnology 13:1074-1085. 
Gallardo, P.P., R. Pedroza-Islas, T. Garcia-Galano, T. Pascual, C. Rosal, A. Sanchez and G. Gaxiola. 2002. Replacement of live food with microbound diet in feeding Litopaneus setiferus (Burkenroad) larvae. Aquaculture Research 33:681-691.

Gladu, P.K., T. Glenn, W. Patterson, G.H. Wikfors, D.J. Chitwood and W.R. Lusby. 1991. Sterols of some diatoms. Phytochemistry 30:2301-2303.

Goldman, J.C., Y. Azav and C.B. Riley. 1982. The effect of $\mathrm{pH}$ in intensive microalgal cultures. I. Biomass regulation. Journal of Experimental Marine Biology and Ecology 57:1-13.

Gonzalez-Araya, R., I. Que'au, C. Quere, J. Moal and R. Robert. 2011. A physiological and biochemical approach to selecting the ideal diet for Ostrea edulis (L.) broodstock conditioning (part A). Aquaculture Research 42:710-726.

Gopakumar, G and B. Ignatius. 2006. Live feed production for marine aquaculture: status, problems and prospects In: Sustain Fish: Proceedings of the International symposium on improved sustainability of fish production systems and appropriate technologies for utilization, 16-18 March, 2005 (eds. B.M. Kurup and K. Ravindran), pp 230-239. School of Industrial Fisheries. Cochin University of Science and Technology. Cochin, India.

Gu, N., Q. Lin and G. Li. 2012. Effect of salinity change on biomass and biochemical composition of Nannochloropsis oculata. Journal of World Aquaculture Society 43:97-106.

Harrison, P.J., P.A. Thompson and G.S. Calderwood. 1990. Effects of nutrient and light limitation on the biochemical composition of phytoplankton. Journal of Applied Phycology 2:45-56.

Hemaiswarya, S., R. Raja, R. R. Kumar, V. Ganesan and C. Anbazhagan. 2011. Microalgae: a sustainable feed source for aquaculture. World Journal of Microbiology and Biotechnology 27:1737-1746.

Huang, X., Z. Huang, W. Wen and J. Yan. 2013. Effects of nitrogen supplementation of the culture medium on the growth, total lipid content and fatty acid profiles of three microalgae (Tetraselmis subcordiformis, Nannochloropsis oculata and Pavlova viridis). Journal of Applied Phycology 25:129-137.

Ju, Z.Y., I.P. Forster and W.G. Dominy. 2009. Effects of supplementing two species of marine algae or their fractions to a formulated diet on growth, survival and composition of shrimp (Litopenaeus vannamei). Aquaculture 292:237-243.

Kanazawa, A. 1982. Penaid Nutrition. In: Biochemical and Physiological Approaches to Shellfish Nutrition. Proceedings of The 2nd International Conference On Aquaculture Nutrition October 27-29 at Lewes/Rehoboth Beach, Delaware (eds. 
G.D. Pruder, C. Langdon and D. Conklin), pp 87-105. Lousiana State University. Baton Rouge, Lousiana.

Kent, M., C.L. Browdy and J.W. Leffler. 2011. Consumption and digestion of suspended microbes by juvenile Pacific white shrimp Litopenaeus vannamei. Aquaculture 319:363-368.

Khatoon, H., S. Banerjee, F. Md Yusoff and M. Shariff. 2010. Effects of salinity on the growth and proximate composition of selected tropical marine periphytic diatoms and cyanobacteria. Aquaculture Research 41:1348-1355.

Khoeyi, Z., J. Seyfabadi and Z. Ramezanpou. 2012. Effect of light intensity and photoperiod on biomass and fatty acid composition of the microalgae, Chlorella vulgaris. Aquaculure International 20:41-49.

Kröger, N., R. Deutzmann and M. Sumper. 1999. Polycationic peptides from diatom biosilica that direct silica nanosphere formation. Science 286:1129-1132.

Lewis, R.J., L.M. Johnson and K.D. Hoagland. 2002. Effects of cell density, temperature, and light intensity on growth and stalk production in the biofouling diatom Achnanthes longipes (Bacillariophyceae). Journal of Phycology 38:11251131.

Lim, C.E. 1998. Feeding penaid shrimp. In: Nutrition and Feeding in Fish (ed. T. Lowell), pp 228-271. Kluwer Academic Publishing. USA.

Lorentz, M., T. Friedl and J.G. Day. 2011. Perpetual maintenance of actively metabolizing microalgal cultures. In: Algal Culturing Techniques (ed. R.A. Andersen), pp 145-187. Elsevier Academic Press and Phycological Society of America. Massachusetts, USA.

Ma, Z. and J.G. Qin. 2012. Replacement of fresh algae with commercial formulas to enrich rotifers in larval rearing of yellowtail kingfish Seriola lalandi (Valenciennes, 1833). Aquaculture Research 45:949-960.

Martínez-Fernández, E., H. Acosta-Salmón and P. C. Southgate. 2006. The nutritional value of seven species of tropical microalgae for black-lip pearl oyster (Pinctada margaritifera, L.) larvae. Aquaculture 257:491-503.

Meseck, S.L., J.A. Alix and G.H. Wikfors. 2005. Photoperiod and light intensity effects on growth and utilization of nutrients by the aquaculture feed microalga, Tetraselmis chui (PLY429). Aquaculture 246:393-404.

Michiels, M. 2009. Bioreactor. EP 2039753. Proviron Presentation. Proviron Advanced Photobioreactor Technology. pp 1-3. 
Millamena, O.M. 1996. Review of SEAFDEC/AQD fish nutrition and feed development research. In: Feeds for Small-Scale Aquaculture. Proceedings of the National Seminar-Workshop on Fish Nutrition and Feeds (eds. C. B. Santiago, R.M. Coloso, O.M. Millamena and I.G. Borlongan), pp. 52-63. SEAFDEC Aquaculture Department, Iloilo. Philippines.

Muller-Feuga, A. 2004. Microalgae for aquaculture. The current global situation and future trends. In: Handbook of Microalgal Culture (ed. Richmond, A.), pp. 352-364. Blackwell, Oxford.

Navarro, N and C. Sarasquete. 1998. Use of freeze-dried microalgae for rearing gilthead seabream, Sparus aurata, larvae: I. Growth, histology and water quality. Aquaculture 167, 179-193.

Nunes, A.J.P., M.V.C Sa and H. Sabry-Neto. 2011. Growth performance of the white shrimp, Litopenaeus vannamei, fed on practical diets with increasing levels of the Antartic krill meal, Euphasia superba, reared in clear-versus green-water culture tanks. Aquaculture Nutrition 17:e511-e520.

Nuñez M, Lodeiros C, de Donato M, Graziani C (2002) Evaluation of microalgae diets for Litopenaeus vannamei larvae using a simple protocol. Aquaculture International 10: $177-187$.

Pedroza-Islas, R., P. Gallardo, E.J. Vernon-Carter, T. Garcia-Galano, C. Rosas, C. Pascual and G. Gaxiola. 2004. Growth, survival, quality and digestive enzyme activities of larval shrimp fed microencapsulated, mixed and live diets. Aquaculture Nutrition 10:167-173.

Ponomarenko, L.P., I.V. Stonik, N.A. Aizdaicher, T.Y. Orlova, G.I. Popovskaya, G.V. Pomazkina and V.A. Stonik. 2004. Sterols of marine microalgae Pyramimonas cf. cordata (Prasinophyta), Attheya ussurensis sp. nov. (Bacillariophyta) and a spring diatom bloom from Lake Baikal. Part B. Comparative Biochemistry and Physiology 138:65-70.

Raja, R., S. Hemaiswarya and R. Rengasamy. 2007. Exploitation of Dunaliella for $\beta$ carotene production. Applied Microbiology and Biotechnology 74:517-523.

Rao, A.R., C. Dayananda, R. Sarada, T.R. Shamala and G.A. Ravishankar. 2007. Effect of salinity on growth of green alga Botryococcus braunii and its constituents. Bioresource Technology 98:560-564.

Raven, J.A. and R.J. Geider. 1988. Temperature and algal growth. New Phytologist 110: 441-461.

Renaud, S.M., D.L. Parry, T. Luong-Van, C. Kuo, A. Padovan and N. Sammy. 1991. Effect of light intensity on the proximate biochemical and fatty acid composition of 
Isochrysis sp. and Nannochloropsis oculata for use in tropical aquaculture. Journal of Applied Phycology 3:43-53.

Renaud, S.M., T. Luong-Van and D.L. Parry. 1999. The gross chemical composition and fatty acid composition of 18 species of tropical Australian microalgae for possible use in mariculture. Aquaculture 170:147-159.

Renaud, S.M., , L.V. Thinh, G. Lambrinidis and D.L. Parry. 2002. Effect of temperature on growth, chemical composition and fatty acid composition of tropical Australian microalgae grown in batch cultures. Aquaculture 211:195-214.

Sanchez, D.R., J.M. Fox, R. Gatlin III and A.L. Lawrence. 2012. Dietary effect of fish oil and soybean lecithin on growth and survival of juvenile Litopenaeus vannamei in the presence or absence of phytoplankton in an indoor system. Aquaculture Research 45 :1367-1379.

Sanchez, J.F., J.M. Fernandez-Sevilla, F.G. Acien, M.C. Ceron, J. Perez-Parra and E. Molina-Grima. 2008. Biomass and lutein productivity of Scenedesmus almeriensis: influence of irradiance, dilution rate and temperature. Applied Microbiology and Biotechnology 79:719-729.

Schmidt, L.E and P.J. Hansen. 2001. Allelopathy in the prymnesiophyte Chrysochromulina polylepis: effect of cell concentration, growth phase, and $\mathrm{pH}$. Marine Ecology Progress Series 216:67-81.

Schwenk , D., J. Seppala, K. Spilling, A. Virkki, T. Tamminen, K.M. OksmanCaldentey and H. Rischer. 2013. Lipid content in 19 brackish and marine microalgae: influence of growth phase, salinity and temperature. Aquatic Ecology 47:415-424.

Senanan, W., S. Panutrakul, P. Barnette, S. Chavanich, V. Mantachitr, N. TangkrockOlan and V. Viyakarn. 2009. Preliminary risk assessment of Pacific white leg shrimp ( $P$. vannamei) introduced to Thailand for aquaculture. Aquaculture. Asia Magazine 14:28-32.

Sheng, L., G. Z.L. Tao, H. Hui and L. Senjie. 2011. Photosynthetic efficiency, cell volume, and elemental stoichiometric ratios in Thalassirosira weissflogii under phosphorus limitation. Chinese Journal of Oceanography and Limnology 29:10481056.

Simental-Trinidad, J.A., M.P. Sánchez-Saavedra and J.G. Correa-Reyes. 2001. Biochemical composition of marine diatoms using as a culture medium a common agricultural fertilizer. Journal of Shellfish Research 20:611-617.

Solovchenko, A.E., I. Khozin-Goldberg, S. Didi-Cohen, Z. Cohen and M.N. Merzlyak. 2008. Effects of light intensity and nitrogen starvation on growth, total fatty acids 
and arachidonic acid in the green microalga Parietochloris incisa. Journal of Applied Phycology 20:245-251.

Sumper, M. and E. Brunner. 2006. Learning from diatoms: Nature's tools for the production of nanostructured silica. Advance Functional Material 16:17-26.

Taelman, S.E., S. De Meester, L. Roef, M. Michiels and J. Dewulf. 2013. The environmental sustainability of microalgae as feed for aquaculture: A life cycle perspective. Bioresource Technology 150:513-522.

Teshima, S. 1982. Sterol metabolism. In: Biochemical and Physiological Approaches to Shellfish Nutrition. Proceedings of the 2nd International Conference on Aquaculture Nutrition October 27-29 at Lewes/Rehoboth Beach, Delaware (eds. G.D. Pruder, C. Langdon and D. Conklin), pp 205-216. Lousiana State University. Baton Rouge, Lousiana.

Valderrama, D and J.L. Anderson. 2012. Shrimp production review. Global Aquaculture Advocate Magazine. January/February 2012 edition. pp 8-9.

Valenzeula-Espinoza, E., V. Gendrop-Funes, R. Pérez-Castañeda and J. WilburnGonzález. 1999. Larval survival of Litopenaeus vannemei (Boone) fed Chaetoceros muelleri produced with agricultural fertilizers. Ciencias Marine 25:423-437.

Walsh, D.T., C.A. Withstandley, R.A. Kraus and E.J. Petrovits. 1987. Mass culture of selected marine microalgae for the nursery production of bivalve seed. Journal of Shellfish Research. 6:71-77.

Wikfors, G.H and M. Ohno. 2001. Impact of algal research in aquaculture. Journal of Phycology 37:968-974.

Wikfors, G.H., J.W. Twarog Jr and R. Ukeles. 1984. Influence of chemical composition of algal food sources on growth of juvenile oysters, Crassostrea virginica. Bulletin of Marine Biology 167:251-563.

Wikfors, G.H., P.K. Gladu and G.W. Patterson. 1991. In search of the ideal algal diet for oysters: recent progress, with emphasis on sterols. Journal of Shellfish Research 10:292 (abstract).

Wikfors, G.H., G.W. Patterson, P. Ghosh, R.A. Lewin, B.C. Smith and J.H. Alix. 1996. Growth of post-set oysters, Crassostrea virginica, on high-lipid strains of algal flagellates Tetraselmis spp. Aquaculture 143:411-419. 


\section{TABLES}

Table 1. Genera of microalgae commonly used in shrimp hatchery (modified from Hemaiswarya et al. 2011)

\begin{tabular}{|c|c|c|}
\hline Genus/species & Class & Utilisation \\
\hline $\begin{array}{l}\text { Isochrysis } \\
\text { (Tisochrysis) }\end{array}$ & Prymnesiophyceae & $\begin{array}{l}\text { Feeding of zooplankton such as Artemia, and used in some shrimp } \\
\text { hatcheries }\end{array}$ \\
\hline Tetraselmis & Prasinophyceae & $\begin{array}{l}\text { Best for larval shrimp and contains natural amino acids that stimulate } \\
\text { feeding in marine animals, complement Nannochloropsis for } \\
\text { producing rotifers as well as for feeding Artemia }\end{array}$ \\
\hline $\begin{array}{l}\text { Thalassiosira } \\
\text { weissflogii }\end{array}$ & Bacillariophyceae & $\begin{array}{l}\text { Applied in the shrimp and shellfish larviculture, considered by } \\
\text { several hatcheries to be the single best alga for larval shrimp, also } \\
\text { used for feeding copepods and Artemia }\end{array}$ \\
\hline Dunaliella & Chlorophyceae & $\begin{array}{l}\text { Source of vitamin A and B12 in some shrimp hatcheries and also for } \\
\text { shrimp coloration }\end{array}$ \\
\hline Chaetoceros & Baci & Source of vitamin A and B1 in some shrimp hatcheries \\
\hline Amphipora spp & Bacillariophyceae & Feeding the white shrimp juveniles \\
\hline Spirulina platensis & Cyanobacteria & Reducing nitrogen levels in black tiger shrimp rearing tanks \\
\hline
\end{tabular}

Table 2. Nutrition requirements of shrimp larvae (modified from Millamena 1996).

\begin{tabular}{lll}
\hline Nutrition & Requirement $(\%)$ & References \\
\hline Protein & $50-57$ & Kanazawa 1981 \\
Essential Amino acids & & \\
Arg & $4.5 \%$ & \\
Lys & $5.3 \%$ & \\
Met + Cys & $3.3 \%$ (Cys, 0.4$)$ & \\
Th & $3.5 \%$ & \\
Val & $3.7 \%$ & \\
Lipid & $12-15$ & \\
Essential Fatty acids & $20: 4 \mathrm{n}-6,20: 5 \mathrm{n}-3$ & \\
& $22: 6 \mathrm{n}-3$ & \\
& $2.6 \% \mathrm{n}-3$ PUFA & \\
& $<0.5 \% 18: 2 \mathrm{n}-6$ & \\
Cholesterol & $0.05-0.5$ (white shrimp) & \\
& 1 (tiger shrimp) & \\
Carbohydrate & 20 & \\
Carotenoids & Desirable for coloration 2004 \\
Vitamin C & 50 mg as ascorbic acid & \\
\hline
\end{tabular}


Table 3. Known nutrient profiles of some microalgae strain.

\begin{tabular}{|c|c|c|c|}
\hline Microalgae strains & Nutrition supplied & Level (\%) & References \\
\hline \multirow[t]{4}{*}{ Chaetoceros muelleri } & Protein & $45.56^{\mathrm{a}}$ & Martinez-Fernandez \\
\hline & Lipid & 12.14 & et al. 2006 \\
\hline & Carbohydrate & 3.74 & \\
\hline & Vitamin C & 16 & Brown et al. 1997 \\
\hline \multirow[t]{2}{*}{ Chaetoceros sp. } & Lipid & 17 & Renaud et al. 1999 \\
\hline & Protein & 36.7 & \\
\hline \multirow[t]{2}{*}{ Skeletonema costatum } & Lipid & 27.9 & \\
\hline & Protein & 13.5 & \\
\hline \multirow[t]{2}{*}{ Tetraselmis suecica } & Vitamin A & $27.07^{\mathrm{b}}$ & Fabregas \\
\hline & Vitamin $\mathrm{C}$ & 17.45 & Herrero 1990 \\
\hline \multirow[t]{3}{*}{ Pavlova salina } & Carbohydrate & $5.23^{\mathrm{a}}$ & \\
\hline & Lipid & 30.55 & Martinez-Fernandez \\
\hline & Protein & 52.91 & et al. 2006 \\
\hline \multirow[t]{3}{*}{ Chlorella stigmatophora } & Vitamin A & $5.13^{b}$ & \\
\hline & Vitamin E & 69.44 & \\
\hline & Biotin & 0.11 & $\begin{array}{ll}\text { Fabregas } & \text { and } \\
\text { Herrero } 1990\end{array}$ \\
\hline Thalassiosira pseudonana & Phytosterol & $63-97^{c}$ & Gladu et al. 1991 \\
\hline T. weissflogii & (24-methylenecholesterol & & \\
\hline Nitzschia breoirostris & and 24-methyl cholesterol) & & \\
\hline \multirow[t]{6}{*}{ Nannochloropsis gaditana } & Carbohydrate & $21.01-28.47^{\mathrm{d}}$ & Ferreira et al. 2009 \\
\hline & Lipid & $18.60-35.34$ & \\
\hline & Protein & $36.19-60.39$ & \\
\hline & PUFA & $12.71-40^{\mathrm{e}}$ & \\
\hline & EPA & $6.76-27$ & \\
\hline & ARA & $3.56-6.90$ & \\
\hline Dunaliella salina & $\beta$ - carotene & $65.66-89.77^{f}$ & Abu-Rezq et al. 2010 \\
\hline \multirow[t]{3}{*}{ Isochrysis sp. (T.Iso) } & Lipid & $29.99^{\mathrm{a}}$ & Martinez-Fernandez \\
\hline & Carbohydrate & 3.33 & et al. 2006 \\
\hline & Protein & 47.77 & \\
\hline \multirow[t]{2}{*}{ Isochrysis galbana } & Vitamin A & $19.57^{\mathrm{b}}$ & \\
\hline & Vitamin C & 30.44 & $\begin{array}{l}\text { Fabregas } \\
\text { Herrero } 1990\end{array}$ \\
\hline
\end{tabular}

$\mathrm{a}=$ percentage of dry weight, $\mathrm{b}=$ percentage of total vitamin, $\mathrm{c}=$ percentage of total sterols, $\mathrm{d}=$ percentage of total organic content (sum of carbohydrate, lipid and protein), e=percentage of total fatty acids, $\mathrm{f}=$ percentage of total carotenoids 
Table 4. Optimum culture environment of some microalgae species commonly used in shrimp hatchery.

\begin{tabular}{|c|c|c|c|c|c|c|c|c|}
\hline \multirow[b]{2}{*}{ Genus/Species } & \multicolumn{6}{|c|}{ Optimum Culture Condition } & \multirow{2}{*}{$\begin{array}{l}\text { Nutrient } \\
\text { Yield } \\
(\%)\end{array}$} & \multirow[b]{2}{*}{ References } \\
\hline & $\begin{array}{l}\text { Photoperiod } \\
\text { (Light:Dark) }\end{array}$ & Light & $\mathrm{pH}$ & $\mathrm{T}$ & $\begin{array}{l}\text { Salinity } \\
\text { (psu) }\end{array}$ & Medium & & \\
\hline Chlorella vulgaris & $16: 8$ & 62.5 & & $25-30$ & & $\mathrm{f} / 2$ & 33.38 SFA & Khoeyi et al. 2012 \\
\hline Thalassirosira weissflogii & $14: 10$ & $\sim 100$ & & 18 & $31 \pm 1$ & $\mathrm{f} / 2$ and $\mathrm{f} / 10$ & $\beta$ - carotene & Sheng et al. 2011 \\
\hline $\begin{array}{l}\text { Isochrysis galbana } \\
\text { Thalassiosira pseudonana }\end{array}$ & & $\begin{array}{l}300 \\
300\end{array}$ & $8.0-8.3$ & $\begin{array}{l}21 \pm 1.5 \\
18\end{array}$ & 6 & $\begin{array}{l}\text { Enriched } \\
\text { seawater }\end{array}$ & $\begin{array}{l}16 \text { DHA } \\
22.62 \mathrm{~L}\end{array}$ & Harrison et al. 1990 \\
\hline Isochrysis sp. & & 300 & & 18 & 6 & $\mathrm{f} / 2$ & $27.2 \mathrm{~L}$ & \\
\hline Isochrysis galbana & & 300 & & 18 & 35 & $\begin{array}{l}f / 2 \\
f / 2\end{array}$ & $12.07 \mathrm{~L}$ & Schwenk et al. 2013 \\
\hline Chaetoceros sp. & $12: 12$ & $80 \pm 2$ & $8.3 \pm 0.1$ & $27-30$ & $25 \pm 1$ & $f / 2$ & $16.8 \mathrm{~L}$ & Renaud et al. 2002 \\
\hline $\begin{array}{l}\text { Marine diatoms (Amphora sp. } \\
\text { and Navicula sp.) }\end{array}$ & $12: 12$ & 31.9 & 8.5 & 28 & $15-25$ & Conway & $\begin{array}{l}40 \mathrm{P} \\
30 \mathrm{~L} \\
20 \mathrm{C}\end{array}$ & Khatoon et al. 2010 \\
\hline Tetraselmis subcordiformis & & 100 & & $20 \pm 1$ & 20 & $\mathrm{f} / 2$ & $29.77 \mathrm{~L}$ & Huang et al. $2013^{*}$ \\
\hline Nannochloropsis oculata & & 150 & & $25 \pm 1$ & 20 & $\mathrm{f} / 2$ & $35.85 \mathrm{~L}$ & \\
\hline Pavlova viridis & & 100 & & $20 \pm 1$ & 20 & $\mathrm{f} / 2$ & $32.10 \mathrm{~L}$ & \\
\hline
\end{tabular}

SFA = saturated fatty acids, $\mathrm{P}=$ Protein, $\mathrm{L}=$ lipid and $\mathrm{C}=$ Carbohydrate $\mathrm{T}=$ temperature in ${ }^{\circ} \mathrm{C}$, Light=light intensity in

umol photon $\mathrm{m}^{-2} \mathrm{~s}^{-1} .{ }^{*}=$ nutrient yield is lipid, protein, carbohydrate, DHA, SFA or b-carotene content when

nitrogen supplementation at $0.22 \mathrm{mmol} \mathrm{N} . \mathrm{L}^{-1}$ 


\section{FIGURE LEGENDS}

Figure 1. Source of microalgae starter culture for hatchery operation in SE Sulawesi.

Image from the map collections of the U.S Central Intelligence Agency

(https://www.cia.gov/library/publications/cia-maps-publications/Indonesia.html).

Figure 2. Typical Provi APT system for efficient microalgae culture (Michiels 2009). 


\section{FIGURES}

\section{Figure 1}

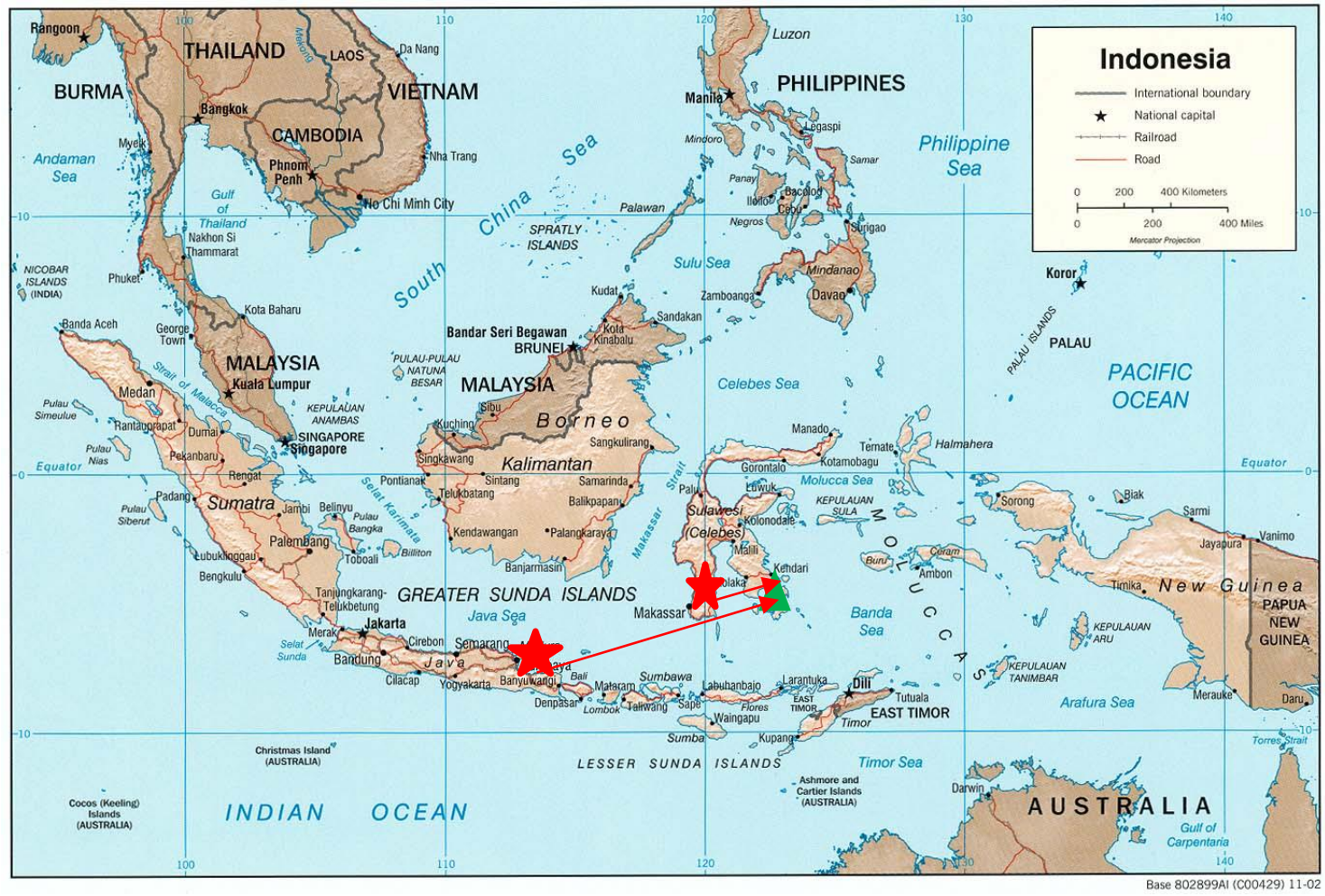


Figure 2

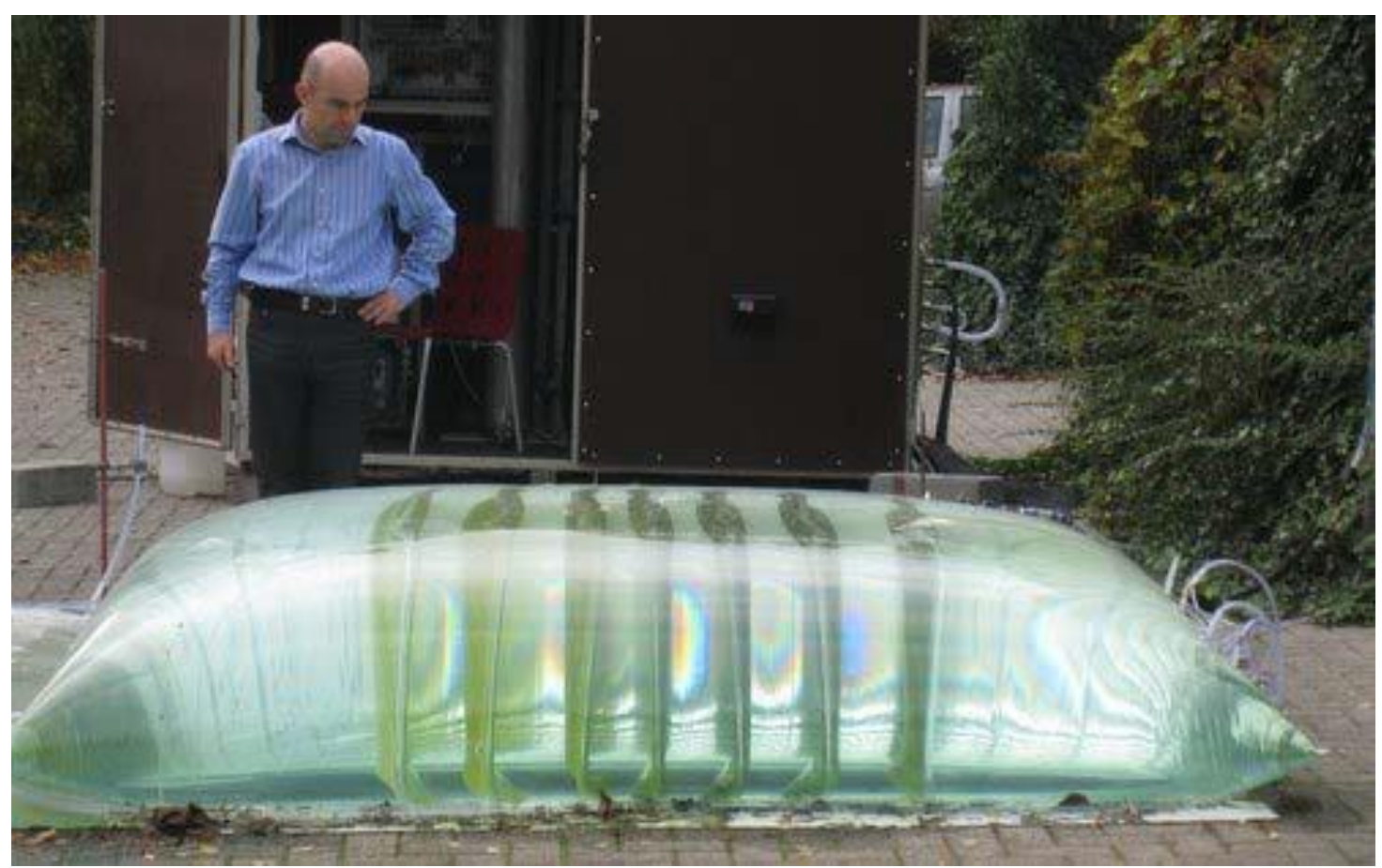




\title{
CHAPTER 2
}

\section{Growth characteristics of newly isolated Indonesian microalgae proposed as feed}

\section{for shrimp hatchery}

\section{By}

\author{
Wa Iba ${ }^{1,2}$, Michael A. Rice ${ }^{1}$, Lucie Maranda ${ }^{3}$, Gary H. Wikfors ${ }^{4}$ \\ ${ }^{1}$ Department of Fisheries, Animal and Veterinary Sciences, University of Rhode Island, Kingston, RI \\ 02881 USA \\ ${ }^{2}$ Faculty of Fisheries and Marine Science, University of Halu Oleo. Kampus Hijau Bumi Tridharma \\ Anduonohu Kendari, SE Sulawesi, 93232. Indonesia \\ ${ }^{3}$ Graduate School of Oceanography, University of Rhode Island, Narragansett, RI 02882 USA \\ ${ }^{4}$ Northeast Fisheries Science Center, NOAA Fisheries Service 212 Rogers Avenue Milford, CT 06460 \\ USA
}

In prepration for submission to Journal of Applied Phycology 


\section{Abstract}

Microalgae were isolated from Kendari Bay and the Wanggu River estuary, Indonesia in summer 2013. Isolates denoted as Kb1-2, Kb1-3, Kb1-5, and Kb2-6 were established to evaluate possible use in Indonesian shrimp hatcheries. A batch culture experiment was conducted for 15 days under salinity levels of 20,25, 30 and 35 practical salinity unit (psu) to investigate growth characteristics of the strains. Tetraselmis chui, Tisochrysis lutea and Chaetoceros neogracile were used to compare growth with Indonesian isolates. Cell numbers were measured every other day and cell size was measured from 50 live cells during the logarithmic phase. Cell sizes of three of the four Indonesian microalgae ranged from 1.2-11.8 $\mu \mathrm{m}$, considered a suitable size for shrimp larvae. Indonesian strains started the logarithmic phase of growth at all salinities tested from 0 to 3 days after inoculation except Kb1-3 that started after a 3 day lag. Increasing cell density over culture period and division rate of Indonesian microalgae during logarithmic phase of growth were similar at all salinities tested, similar to T. chui, Ti. lutea and C. neogracile. However, final biomass after 15 days of culture of all microalgal strains was affected by culture salinities tested. Indonesian microalgal strains showed similar dry weight and ash free dry weight to smaller-cell strains, $T i$. lutea and C. neogracile. Indonesian microalgal strains (other than Kb2-6) may be good candidates for mass culture in shrimp hatcheries based upon their cell size, ability to survive long culture periods, and wide salinity tolerance.

Key words: microalgae, shrimp, aquaculture, Indonesia 


\section{Introduction}

Microalgae have been mass cultured for many years as live food for mollusk, shrimp, and fish culture during the hatchery stage (Wikfors and Ohno 2001; MartinezFernandez and Southgate 2007; Kent et al. 2011; Iba et al. 2014). Replacing live microalgae with artificial diets or dried microalgae has so far been unsuccessful (Gallardo et al. 2002; Sanchez et al. 2012; Ma and Qin 2012; Arney et al. 2015); however, partial substitution and frozen microalgal replacement diets may be promising (Gui et al. 2015; Southgate et al. 2016). Nevertheless, the availability of live microalgae in hatcheries for marine cultured species (fishes, shrimps and mollusks) remains critical to ensure a continuous supply of healthy seed for aquaculture.

The demand for shrimp products in both local and international markets continues to increase, partly because of increasing world population; therefore, a sufficient supply of shrimp larvae and post larvae to farmers is necessary to meet demand. Generating hatchery seed stock is one critical component in the production chain of shrimp for the aquaculture industry. A survey conducted by the Global Aquaculture Alliance in 2011 revealed that seed stock quality and availability still were the main issues in producing good quality shrimp in Asia (Valderrama and Anderson 2012). With effective microalgal feeds, hatcheries are expected to produce robust, healthy and inexpensive seed stock for commercial use.

South East Sulawesi (SE-Sulawesi), Indonesia, has a great potential for unexploited microalgae because of the region's abundant and diverse water resources as habitats for microalgae, both in fresh and seawater. Approximately $75 \%\left(115,000 \mathrm{~km}^{2}\right.$ of 153,000 $\mathrm{km}^{2}$ ) of the SE-Sulawesi territory consists of marine areas (Ministry of Forestry of Government of Indonesia 2013). Local microalgae from SE-Sulawesi $\left(02^{\circ} 45^{\prime}\right.$ to 
$06^{\circ} 15^{\prime} \mathrm{S}, 120^{\circ} 45^{\prime}$ to $124^{\circ} 45^{\prime} \mathrm{E}$ ) are not yet utilized, despite their potential to support biofuel production, food supplements, and aquaculture within the country. Most shrimp aquaculture in SE-Sulawesi currently relies upon microalgae starters supplied from the south Sulawesi and Java regions that impose high operational costs to aquaculture farms and hatcheries. The price of microalgae starter culture obtained from Java and south Sulawesi such as Spirulina sp., Chorella, and Dunaliella, is in the range of US\$10-30 $\mathrm{L}^{-}$ ${ }^{1}$ (Iba et al. 2014). That price can be reduced by up to $50 \%$ if the starter culture were to be provided within SE-Sulawesi region as the high transportation cost will be no longer part of the production equation. Importing microalgae from other regions also increases greenhouse gas $(\mathrm{GHG})$ emissions associated with air and ground transportation (Edwards-Jones 2010) and exposes receiving areas to risks from non-native species invasions, including from the algae themselves and any contaminating microorganisms. To reduce cost and non-native introduction issues, the use of locally-isolated, cultured microalgae in local hatcheries may be considered. Microalgal research, therefore, is desirable, not only to conserve and make use of local resources, but to serve in supporting a number of economic activities including aquaculture in Indonesia.

Kendari Bay and the Wanggu River are important habitats and ecosystems that support SE-Sulawesi's economic growth and development. Currently, Kendari Bay receives many human inputs, particularly in the form of sedimentation because of inappropriate land use in surrounding areas. The Wanggu River drains into Kendari Bay and is one of the larger rivers in the Kendari municipal jurisdiction. As most of the Kendari population lives in the Wanggu River watershed, this habitat also receives pressures in the form of organic and inorganic pollution. Habitats such as the Wanggu 
River and Kendari Bay that receive high nutrient input from wastewater may provide some species of microalgae that potentially can grow easily under cultivation in the laboratory. Cai et al. (2013) showed that several species of microalgae, such as Chlorella sp., Scenedesmus sp., Oscillatoria sp. and Isochrysis sp., some of which are commonly used in aquaculture hatcheries, tend to grow better in high nutrient effluent waters. In a preliminary study of phytoplankton resources in Kendari Bay, four dominant species of microalgae from three different classes were found (Iba et al. 2009). This study, therefore, was aimed to isolate and to characterize the growth of local strains of microalgae from Kendari Bay SE-Sulawesi that may be of potential use in shrimp hatcheries.

\section{Materials and Methods}

\section{Sampling and Isolation of Microalgae}

The samples for this experiment were collected from two locations: the marine

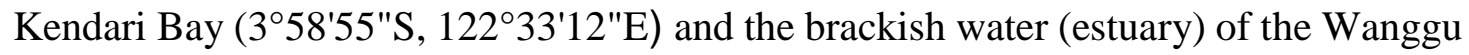
River $\left(3^{\circ} 58^{\prime} \mathrm{S}, 122^{\circ} 35^{\prime} \mathrm{E}\right)$ at up to $2-\mathrm{m}$ depth in each location. Fifty liters of seawater were filtered through a plankton net $(25-\mu \mathrm{m}$ mesh) to remove zooplankton. The filtrate was collected in the sample jar of the plankton net and then $30-\mathrm{mL}$ samples from the filtrate were taken and distributed into two 15-mL Falcon tubes and placed in a cooler. Water samples containing natural microalgae were brought to the Laboratory of Fisheries (Haluoleo University) and kept overnight at room temperature before being brought to USA, specifically the National Marine Fisheries Service Milford Laboratory (Milford) and the University of Rhode Island (URI) for isolation. Fourteen days following collection, water samples were enriched in $10-\mathrm{mL}$ culture tubes containing 
Guillard's f/8 medium for marine species (Wikfors and Ohno 2001; Ponomorenko et al. 2009). Single-cell isolation at the URI was conducted using capillary pipettes according to procedures described by Andersen and Kawachi (2005)

At Milford, isolation was performed using a flow cytometer (JSAN Model DCS260U Desktop Cell Sorter, Bay Bioscience Co., Ltd., Kobe, Japan). The samples were

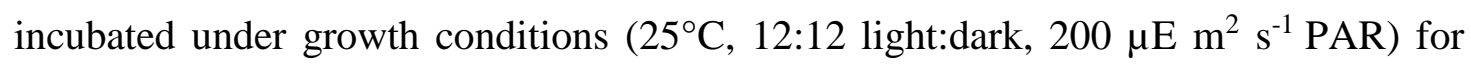
several days upon receiving to re-activate photosynthetic physiology. Microscope observation revealed 5-10 dominant microalgal taxa (organisms with chlorophyll fluorescence) in each field sample; several morphotypes were abundant. After concentration $10 \mathrm{x}$ by gentle centrifugation $(500 \mathrm{x} \mathrm{g})$, samples were run through the JSAN flow cytometer and visualized as plots of Forward Scatter (FSC, proportional to size) and FL3 (chlorophyll fluorescence) or Side Scatter (SSC, internal complexity) and FL3. Sort regions were drawn in the centers of aggregations of events with similar SSC/FL3 - analogous to targeting the bulls-eye - and the cytometer was programmed to deposit a single cell in each well of a 96-well plate using the plate-deposition unit on the instrument. Pre-sterilized well-plates were prepared to receive cells by aseptically pipetting $500 \mu \mathrm{L}$ of sterilized $\mathrm{f} / 2$ medium into each well. As a precaution, the instrument also was programmed to deposit 50 cells into small test tubes containing 500 $\mu \mathrm{L}$ of sterilized culture medium, either f/2 or L1 (Guillard and Hargraves, 1993) enriched Milford Harbor seawater.

Micro-well plates containing sorted cells were covered to minimize evaporation and incubated under the growth conditions noted above. Every 2-3 days, wells were observed with an inverted light microscope for evidence of cell proliferation. Of 300+ 
wells receiving sorted cells, none yielded viable cultures; however, several test tubes into which 50 cells had been sorted showed growth. Growing isolates were transferred to $10-\mathrm{mL}$ test tubes containing $5 \mathrm{~mL} \mathrm{f} / 2, \mathrm{f} / 2+\mathrm{Si}$, or $\mathrm{L} 1$ medium and incubated under growth conditions. Cultures that established robust growth were observed microscopically for provisional identification and determination of possible unialgal status. Cultures appearing to be unialgal were analyzed with an analytical flow cytometer (B-D BioSciences C6, San Jose, CA) to determine if more than one chlorophyll-containing particle was present. Following microscopic and flowcytometric analysis, 3 unique, unialgal cultures were found: two appeared to be diatoms, which grew well in $\mathrm{f} / 2+\mathrm{Si}$; and one was a brown flagellate that grew best in L1. These three isolates obtained from the flow-cytometric isolation effort were sent to the University of Rhode Island for perpetuation and experimentation.

\section{Microalgal Culture}

Microalgae were cultured based upon methods described by Martinez-Fernandez et al. (2006) and Rohani-Ghadikolaei (2012). Batch cultures of isolated microalgae were grown in 500-mL glass culture bottles containing $450 \mathrm{~mL}$ of sterilized seawater with $\mathrm{f} / 2$ medium, at $28-30^{\circ} \mathrm{C}$, under a $12: 12 \mathrm{~h}$ light: dark cycle with $160-170 \mu$ mol photon $\mathrm{m}^{-2}$ $\mathrm{s}^{-1} \mathrm{PAR}$ and gentle mixing once a day. Indonesian microalgal strains were inoculated at density ranging from 5.4-6.3 $\times 10^{4}$ and 2.1-3.0 $\times 10^{4}$ cells $\mathrm{mL}^{-1}$ for Kb1-2 and Kb1-3, respectively. A preliminary study with the newly-isolated strains, particularly Kb1-5, showed that they performed better with cell density above $5 \times 10^{4} \cdot \mathrm{ml}^{-1}$ at inoculation; therefore, the inoculum at first day of the growth experiment was increased to facilitate good growth, therefore Kb1-5 was inoulated at density of 8.3-12.8 $\times 10^{4}$ cells $\mathrm{mL}^{-1}$. Cell 
density at inoculation for comparison species ranged from $0.2-0.6 \times 10^{4}, 0.7-1.0 \times 10^{4}$, and $7.0 \times 10^{4}$ cells $\mathrm{mL}^{-1}$ for $C$. neogracile, T. chui and Ti. lutea, respectively. The effect of salinity on microalgal growth was tested at 35, 30, 25 and 20 psu with four replicates for each salinityto accommodate a wide range of salinity possible for microalgae growth including their natural condition which is in the range of 22-25 psu. Seawater used in this study was artificial seawater (Instant Ocean Sea Salt mix) at initial salinity of 30 psu. To be practical, we added artificial salt (Morton Kosher Salt) to obtain 35 psu salinity and distilled water to decrease the salinity to 25 and 20 psu.

Three microalgae strains widely used in aquaculture were used as control species: Ti lutea (T-ISO; CCMP-1324), T. chui (CCMP-884) that were obtained from the shellfish laboratory at Roger Williams University, Bristol, RI, USA, and $C$. neogracile (strain Chaet B) from Milford Laboratory, Connecticut, USA. Cell density of cultured microalgae was recorded every two or three days by fluorometry (AquaFluor Handheld Fluorometer/Turbidimeter Turner Designs Sunnyvale California, USA) to measure increasing fluorescence intensity and wavelength distribution over culture period (Fig. 1). A measurement was conducted in each replicate for all salinities tested for 15 days. Furthermore, the cells during logarithmic phase were counted using a particle counter (Multisizer ${ }^{\mathrm{TM}} 4$ COULTER COUNTER $^{\circledR}$, Beckman Coulter, Brea, California, USA). A regression relationship between Coulter counts and fluorometer readings was used to estimate cell counts from fluorometer readings. Finally, division rate $(\mathrm{k})$ during logarithmic phase of the culture at each salinity for each species was calculated based upon cell counts (N) at times (t) (Guillard, 1973; Wood et al, 2005) as follows: 


$$
\mathrm{k}=\frac{1}{\ln 2}\left\lceil\ln \left(N_{1} / N_{0}\right) /\left(t_{1}-t_{0}\right)\right\rceil
$$

Cell sizes of live cultured microalgae were obtained using image analysis software (Nikon NIS-Elements AR 3.0) to measure length, width and diameter of 50 non-dividing microalgal cells from each species, in logarithmic and stationary phases, and at each of the salinities.

Identification of the isolated strains was conducted using Scanning Electron Microscopy (SEM, JEOL 5900 LV system, SEM Tech Solutions, USA) on material preserved with $2 \%$ glutaraldehyde in seawater. The images of two strains of Indonesian microalgae, Kb1-3 and Kb1-5, were not successfully acquired using SEM; therefore, microphotographs of these strains were taken using a light microscope (Nikon Eclipse 80i equipped with a QImaging Retiga 2000R digital camera) at 40x magnification.

Yield of each cultured microalgal strain was calculated as an average of final cell density (cells $\mathrm{mL}^{-1}$ ) at stationary phase of 13 and 15 days of culture. In addition, dry weight (DW) and ash-free dry weight (AFDW) were measured following the method of Mohameini and Borowitzka (2013). At the end of experiment (Fig.1), four replicates of $100 \mathrm{~mL}$ of cultured microalgae at each salinity were filtered using preweighed, pre-combusted $\left(1 \mathrm{~h}, 100 \pm 5^{\circ} \mathrm{C}\right) \mathrm{GF} / \mathrm{F}$ filters $(\Theta=47 \mathrm{~mm})$, and rinsed with 10 $\mathrm{mL}$ 0.65-M ammonium formate to eliminate salts. Filters were oven dried at $100 \pm 5^{\circ} \mathrm{C}$ for $1 \mathrm{~h}$, placed overnight over $\mathrm{KMnO}_{4}$ salts in a vacuum desiccator, and weighed to obtain dry weight of the algae. The dried algae on filters were then combusted at $450^{\circ}$ $\mathrm{C}$ for $5 \mathrm{~h}$ using a muffle furnace and weighed again to obtain AFDW. DW and AFDW were calculated using the following equations: 


$$
\begin{gathered}
\text { DW }\left(\frac{\mu \mathrm{g}}{\mathrm{mL}}\right)=\frac{\text { Weight of filter with algae - weight of filter }}{\text { sample volume }} \\
\text { AFDW }\left(\frac{\mu \mathrm{g}}{\mathrm{mL}}\right)=\frac{\text { Weight of filter with dried algae - weight of filter after drying }(\mathrm{DW})}{\text { sample volume }}
\end{gathered}
$$

\section{Statistical Analysis}

Data on cell density of all microalgal strains at each salinity tested were subjected to repeated measures ANOVA; whereas, the differences in cell size, yield, division rate, DW and AFDW across cultured microalgae were analyzed using two-way ANOVA. The differences in cell size, yield, division rate, DW and AFDW of individual microalgal strains at each salinity tested were analyzed using one-way ANOVA. All statistical analyses were performed using SAS Enterprise Guide 7.1.

\section{Results}

\section{Indonesian Microalgal Isolates}

We successfully isolated four strains of microalgae from Kendari Bay SESulawesi, and these were denoted as Kb1-2, Kb1-3, Kb1-5 and Kb2-6 (Table 1). Kb12 is a Chaetoceros species (Class Bacillariophyceae) as shown by SEM and later confirmed by genomic sequences of $18 \mathrm{~S}$ and $28 \mathrm{~S}$ rDNA (Fig. 2, data on genomics are not shown here, paper is in preparation). The isolate labeled Kb1-3 has a coccoid morphology and sometimes cells clump together; Kb1-5 is irregular in shape and has relatively smaller sizes compared to other local isolates (Fig. 3). Neither Kb1-3 nor Kb1-5 were identified. Kb2-6 identified as Melosira cf. moniliformis forms colonies and has a larger cell size than $10 \mu \mathrm{m}$, suggesting that the strain is not suitable for aquaculture and therefore was excluded from subsequent culture experiments. 


\section{Cell Size and Growth of Indonesian Microalgal Isolates}

Microalgal strains isolated from SE-Sulawesi, Indonesia ranged from 1.2 to 11.8 $\mu \mathrm{m}$ in size (Figs. 2 and 3, Table 1), and the differences in cell size within strains were significant. Each strain had a different mean cell size in response to salinity except for Kb1-5. Of Indonesian strains, Kb1-2 had the largest cell size when cultured at $30 \mathrm{psu}$; whereas, Kb1-3 had similar cell size at 35 psu to those cultured at 20, 25 and 30 psu. $C$. neogracile had a smaller cell size at $25 \mathrm{psu}$; whereas, T. chui was larger at 25 and 30 psu. Ti. lutea had larger cell sizes at low (20 psu) and high (35 psu) salinities tested, but cell size was smaller at 25 and 30 psu (Table 2). T. chui was the largest species across all salinities tested, and Kb1-5 was the smallest ( $\mathrm{p}<.0001) . \mathrm{Kb} 1-2$ had a similar cell size to C. neogracile; whereas, cell size of Kb1-3 was similar to Ti. lutea (Table 5). Relatively higher percentages of smaller cell sizes were observed at higher salinities for most of the strains with the exception of $C$. neogracile and T. chui (data not shown).

Salinity or age of culture within salinity alone and the interaction of salinity and age of culture did not have a significant effect on the increase in cell density over time in all microalgal strains cultured. However, strain $(\mathrm{p}=<.0001)$, age of culture within strain $(\mathrm{p}=0.003)$, and the interaction of culture age and strain $(\mathrm{p}=<.0001)$ did have a significant effect on cell density of algae. The highest cell densities were observed in Kb1-3 cultures at 25 psu on day 15 and Kb1-5 at 25 psu on day 8; 65.9 and 42.4 cells $\mathrm{mL} \cdot 10^{5}$, respectively. Most strains began to enter the stationary phase after day 10 except for Kb1-2 and Kb1-5 that reached stationary phase at day 8. Microalgal growth generally started to show a significant increase on day 3 after inoculation except for $T$. chui and Ti. lutea that experienced a lag phase on that day. Significant growth continued 
up to day 8 for all Indonesian microalgal strains and C. neogracile except Kb1-5 at 20 and $30 \mathrm{psu}$ that showed a decreasing growth after day 6. T. chui and Ti. lutea continued to have significant growth up to day 9 and 10, respectively (Fig. 4).

Division rates decreased as the culture reached a late logarithmic and onset of stationary phase (Fig. 5). There were no significant differences in division rate during logarithmic growth phase across all salinity levels tested as well as the interaction between salinity and strain among microalgal strains. The differences in division rate during $\log$ phase were between strains only $(\mathrm{p}=0.002)$. Within microalgal strains, salinity only affected the division rate of one Indonesian strain, Kb1-2 (Chaetoceros sp., $\mathrm{p}=<.0001)$ but did not affect Kb1-5 and Kb1-3. Also, salinity did not affect the division rate during $\log$ phase of growth in C. neogracile, T. chui, or Ti. lutea. Among Indonesian microalgae tested, Kb1-5 showed the highest division rate during log phase, similar to T. chui and C. neogracile. Kb1-2 and Kb1-3 strains had lower division rates similar to Ti. lutea (Fig. 5).

Differences among microalgal strains $(\mathrm{p}=<.0001)$, as well as salinity $(\mathrm{p}=<.0001)$ and the interaction between strain and salinity $(\mathrm{p}=<.0001)$, affected yields of cultured microalgae. Of Indonesian strains, higher final biomass was observed at $35 \mathrm{psu}$ in Kb1-3; whereas, yields at other salinities were not significantly different from each other. Conversely, in Kb1-2 and Kb1-3, higher yield was obtained in both at lower 20 psu and at higher 30 and 35 psu salinity. Kb1-2 cultured at 25 psu produced the lowest yield; whereas, yield of Kb1-3 at the same salinity was similar to that at 20 and 30 psu. Final yields of C. neogracile and T. chui were not affected by salinity, unlike Ti. lutea. Final yield of Ti. lutea was significantly higher at 25, 30 and 35 psu than at 20 psu 
(Table 3). Regardless of salinity, two Indonesian strains, Kb1-3 and Kb1-5, showed highest yields among all microalgae tested; whereas, yield of Kb1-2 was similar to $T i$. lutea and $C$. neogracile. T. chui had the lowest yield but statistically similar to $C$. neogracile (Table 5).

Both dry weight (DW) and ash free dry weight (AFDW) across microalgae strains were not affected by salinity or the interaction between salinity and strains but by differences among strains themselves $(\mathrm{p}=<.0001)$. DW and AFDW of Indonesian microalgal strains were similar at all culture salinities except for Kb1-2. Higher DW and AFDW of Kb1-2 were observed at 20, 30 and 35 psu than at 25 psu. Salinity affected DW and AFDW of C. neogracile and Ti. lutea but not T. chui. Higher DW and AFDW were obtained at higher salinity, $35 \mathrm{psu}$, in $C$. neogracile culture and at 30 and 35 psu in Ti. lutea culture, respectively (Table 4). Among microalgal strains, DW of all Indonesian microalgal strains was similar to Ti. lutea and C. neogracile. Moreover, DW of T. chui was the highest compared to the rest of the strains (Table 5).

\section{Discussion}

Of three distinct strains that were included in the growth experiment, one strain was identified as Chaetoceros sp., a diatom species. The size of microalgae in this growth experiment ranged from 1.2-11.8 $\mu \mathrm{m}$, considered as either pico or nanoplankton, thus is suitable as feed for aquaculture hatcheries, particularly shrimp aquaculture as suggested by Brown (2002) and Becker (2004), and comparable to those extensively used in aquaculture, particularly C. neogracile and Ti. lutea.

Indonesian microalgae showed similar growth rates during logarithmic phase across all tested salinities, suggesting that they are euryhaline species, although they 
produced different final biomass depending upon salinity. This is consistent with their natural habitat being an estuary that might be suitable for shrimp hatchery conditions. Diatom species, such as C. neogracile and Kb1-2 (Chaetoceros sp.) used in this study, tended to produce smaller cell sizes over time. Different classes of microalgae are known to undergo different cell division mechanisms, either reducing or increasing cell size during lifecycles. In diatoms, if rapid individual cell growth after asexual reproduction occurs, there will consequently be a reduction in average population cell size over time because of the reproductive mechanism in which one of the new daughter cells is always smaller than the parent cell (Round 1990; Lee 2008). As for flagellates without silica cell walls, such as T. chui and Prymnesiophyceae, such as Ti. lutea, used in this study, these taxa tend to produce similar or larger cell sizes under favorable environmental conditions (Danquah et al. 2009).

Salinity, in the range tested, was not a limiting factor for growth of any microalgal strains in this study. The growth is most likely limited by other environmental factors such as light intensity, temperature, or culture nutrients, which were not addressed in this study, and genetic traits of each strain as suggested by Hu et al. (1998), Lee and Kim (2002) and Wood (2005). Differences in cell density, thus dry weight and ash free dry weight, may be driven by cell size, cell density at inoculation, and harvest time, as well as other culture conditions such as light intensity and temperature (Hu et al. 1998; Richmond 2004). Richmond (2004) stated that output rate, i.e. yield of a microalgal culture, using Spirulina as a model, changed over time, becoming lower as the growth rate decreased during stationary phase of the culture cycle. In this study, Kb1-5 with the smallest cell size of all strains, yet with higher 
inoculated cell numbers, showed the highest cell numbers over the culture period, but with considerably lower dry weight and ash-free dry weight at the end of experiment. Conversely, T. chui, with its larger cell sizes and lower inoculation numbers, exhibited the lowest cell numbers on all days of culture, but consistently exhibited higher dry weights across all salinities tested.

The growth of Indonesian microalgal strains, particularly Kb1-3 and Kb1-5, was higher than T. lutea although T. lutea showed a similar growth to Kb1-2, Chaetoceros sp. Chaetoceros sp. and Kb1-3 did not enter stationary phase at day 15 of culture, except for Kb1-3 at 25 psu. This growth pattern was different from Miller et al. (2014) who found that late stationary phase occurred at day 12 in cultured Chaetoceros calcitrans. Finally, maximal cell density of $T$. lutea during stationary phase reported here was almost three times lower than that reported by Huerlimann et al. (2010), but similar to that reported by Renaud et al. (1999) and almost six times lower than that reported by Fidalgo et al. (1998). The variation in final cell density may be attributable to different cell density at inoculation as well as culture conditions, such as light intensity, culture medium, temperature, and aeration (Fidalgo et al., 1998; Borowitzka, 2012; Gorgonio et al., 2013). Further studies would be needed to determine if the Indonesian strains stopped dividing because of nutrient or light limitation.

Although prolonged culture up to late stationary phase may compromise the harvested biomass as shown in this study with Kb1-2 and Kb1-5 strains, some research has shown that this practice will increase the nutritional value of microalgae particularly total lipid and fatty acid content (Patil et al. 2007; Schwenk et al. 2013; Nalder et al. 2015). If microalgae are to be used as food for aquaculture, however, it is important to 
keep both cell density and nutrition variables at optimal levels; therefore, harvest for feeding purposes might best be conducted during late logarithmic phase or in this study at day 6 or 7 of culture. Our study on nutritional content of these newly isolated microalgal strains (Chapter 3) showed that their total lipid content after 15 days of culture or during stationary phase ranged from 11.8-74.0\% which was well above lipid requirement for shrimp hatchery feeding according to Nuñez et al. (2000). Furthermore, the abilities to survive under wide ranges of salinity and nutrient-deficient conditions are important traits of microalgae to be used in aquaculture. In the face of changing climate, increasing variability in weather conditions may alter the freshwater supply and thus salinity levels in estuaries (Taylor et al. 2012; Elliot et al. 2014, Schwe et al. 2014). Therefore, culturing euryhaline microalgae species for aquaculture that are accustomed to salinity fluctuations is one promising solution to continue producing high quality seafood products reliably over time. In summary, three of four local isolates from an Indonesian estuary were shown to have size, environmental tolerance, and growth characteristics consistent with needs as feeds in local shrimp hatcheries. This finding is consistent with an initiative to utilize local microalgae for aquaculture purposes to reduce production cost, promote sustainable and environmentally friendly aquaculture practices in the region and Indonesia in general. Finally, further identification of the strains using genetic tools such as DNA sequencing may be useful in revealing their taxonomic identity and may help to further describe the microalgal biodiversity in the region. 


\section{References}

Andersen RA, Kawachi M (2005) Traditional microalgae isolation techniques. In: Andersen, RA (ed) Algal culturing techniques. Elsevier Academic Press and Phycological Society of America, Massachusetts, USA, pp 83-100.

Arney B, Liu W, Forster IP, McKinley RC, Pearce CM (2015). Feasibility of dietary substitution of live microalgae with spray-dried Schizochytrium sp. or Spirulina in the hatchery culture of juveniles of the Pacific geoduck clam (Panopea generosa). Aquaculture 444:117-133

Becker W (2004) Microalgae for aquaculture: the nutritional value of microalgae for aquaculture. In Richmond, A. (Ed) Handbook of microalgal culture: biotechnology and applied phycology. Blackwell Publishing Ltd. Iowa. USA, pp 380-391.

Brown MR (2002) Nutritional value of microalgae for aquculture. In Cruz-Suárez LE, Ricque-Marie D, Tapia-Salazar M, Gaxiola-Cortés, MG. \& Simoes, N. (eds.). Avances en Nutrición Acuícola VI. Memorias del VI Simposium Internacional de Nutrición Acuícola. 3 al 6 de Septiembre del 2002. Cancún, Quintana Roo, México

Cai T, Park SY, Li Y (2013) Nutrient recovery from wastewater streams by microalgae: status and prospects. Renewable and Sustainable Energy Review 19:360-369

Danquah MK, Gladman B, Moheimani N, Forde GM (2009) Microalgal growth characteristics and subsequent influence on dewatering efficiency. Chemical Engineering Journal 151:73-78

Edwards-Jones G (2010) Does eating local food reduce the environmental impact of food production and enhance consumer health? Symposium on 'Food supply and quality in a climate-changed world'. Proceedings of the Nutrition Society 69:582591

Elliott J, Deryng D, Müller J, Frieler K, Konzmann M, Gerten D, Glotter M, Flörke M, Wada Y, Best N, Eisner S, Fekete BM, Folberth C, Foster I, Gosling SN, Haddeland I, Khabarov N, Ludwig F, Masaki Y, Olin S, Rosenzweig C, Ruane AC, Satoh Y, Schmid E, Stacke T, Tang Q, Wisser D (2014) Constraints and potentials of future irrigation water availability agricultural production under climate change. PNAS 111:3239-3244

Gui Y, Zamora L, Dunphy BJ, Jeffs AG (2015) Evaluation of the formulated diet MySpat for feeding hatchery-reared spat of the green-lipped mussel, Perna canaliculus (Gmelin, 1791). Aquaculture Research 1-6

Guillard R.R.L, Hargraves P.E (1993) Stichochrysis immobilis is a diatom, not a chrysophyte. Phycologia 32: 234---236. 
Hu Q, Zarmi Y, Richmond A (1998) Combined effects of light intensity, light path, and culture density on output rate of Spirulina platensis (Cyanobacteria). Eur. J. Phycol 33: 165-71.

Iba W, Bahtiar, Emiyarti, Mustafa, A (2009) Identification of species biodiversity in Kendari Bay. Research Report to the Development and Planning Agency Kendari Municipal South East Sulawesi Indonesia

Iba W, Rice MA, Wikfors GH (2014) Microalgae in eastern pacific white shrimp, Litopenaeus vannamei (Boone 1931) hatcheries: a review on roles and culture environments. Asian Fisheries Science Journal 27: 212-233

Lee JB, Kim BY (2002) Growth characteristics of five microalgal species isolated from Jeju Island and four microalgal stock strains in hatchery. Algae 17: 117-125

Lee RE (2008) Phycology. Cambridge University Press, New York, 547p

Ma Z, Qin JG (2012) Replacement of fresh algae with commercial formulas to enrich rotifers in larval rearing of yellowtail kingfish Seriola lalandi (Valenciennes, 1833). Aquaculture Research 1-12

Martínez-Fernández E, Acosta-Salmón H, Southgate PC (2006) The nutritional value of seven species of tropical microalgae for black-lip pearl oyster (Pinctada margaritifera, L.) larvae. Aquaculture 257: 491-503

Ministry of Forestry of Government of Indonesia (2013) South east sulawesi profile. Jakarta.

Moheimani NR, Borowitzka MA, Isdepsky A, Sing SF (2012) Standard methods for measuring growth of algae and their composition. In Borowitzka MA, Moheimani NR (eds) Algae for biofuel and energy. Springer, New York, pp 266-284

Nalder TD, Miller MR, Packer MA (2015) Changes in lipid class content and composition of Isochrysis sp. (T-Iso) grown in batch culture. Aquaculture International 23:1293-1312

Nuñez M, Lodeiros C, de Donato M, Graziani C (2002) Evaluation of microalgae diets for Litopenaeus vannamei larvae using a simple protocol. Aquaculture International 10: 177-187.

Patil V, Källqvist T, Olsen E, Vogt G, Gislerød HR (2007) Fatty acid composition of 12 microalgae for possible use in aquaculture feed. Aquaculture International $15: 1-9$

Ponomarenko LP, Stonik IV, Aizdaicher NA, Orlova TY, Popovskaya GI, Pomazkina GV, Stonik VA (2004) Sterols of marine microalgae Pyramimonas cf. cordata 
(Prasinophyta), Attheya ussurensis sp. nov. (Bacillariophyta) and a spring diatom bloom from Lake Baikal. Comparative Biochemistyr and Physiology Part B 138: $65-70$

Richmond A (2004) Biological principles of mass cultivation. In Richmond A (ed) Handbook of microalgal culture: biotechnology and applied phycology. Blackwell Publishing Ltd, Iowa, pp 125-177

Rohani-Ghadikolaei K, Ng WK, Abdulalian E, Naser A,Yusuf A (2012) The effect of seaweed extracts, as a supplement or alternative culture medium, on the growth rate and biochemical composition of the microalga, Isochrysis galbana (Park 1949). Aquaculture Research 43:1487-1498

Round FE, Crawford RM, Mann DG (1990) The diatoms: biology and morphology of the genera. Cambridge University Press, Cambridge, 744p

Schewe J, Heinke J, Gerten D, Haddeland I, Arnell NW, Clark DB, Dankers R, Eisner S, Fekete BM, Colón-González FJ, Gosling SN, Kim H, Liu X, Masaki Y, Portmann FT, Satoh Y, Stacke T, Tang Q, Wada Y, Wisser D, Albrecht T, Frieler K, Piontek F, Warszawski L, Kabat P (2014) Multimodel assessment of water scarcity under climate change. PNAS 111:3245-3250

Schwenk D, Seppälä J, Spilling K, Virkki A, Tamminen T, Oksman-Caldentey KM, Rischer H (2013) Lipid content in 19 brackish and marine microalgae: influence of growth phase, salinity and temperature. Aquatic Ecology 47:415-424

Southgate PC, Beer AC, Ngaluafe P (2016) Hatchery culture of the winged pearl oyster, Pteria penguin, without living micro-algae. Short communication. Aquaculture 451:121-124

Taylor RG, Scanlon B, Döll P, Rodell M, van Beek R, Wada Y, Longuevergne L, Leblanc M, Famiglietti JS, Edmunds M, Konikow L, Green TR, Chen J, Taniguchi M, Bierkens MFP, Mac Donald A, Fan Y, Maxwell RM, Yechieli Y, Gurdak JJ, Allen DM, Shamsudduha M, Hiscock K, Yeh PJF, Holman I, Treidel H (2012) Ground water and climate change. Nature Climate Change 1744 : 1-8

Valderrama D, Anderson JL (2012) Shrimp production review. Global aquaculture advocate magazine. January/February 2012 edition, pp 8-9.

Wikfors GH, Ohno M (2001) Impact of algal research in aquaculture. Journal of Phycology 37: 968-974.

Wood AM, Everroad AC, Wingard LM ( 2005) Measuring growth rates in microalgal cultures. In Andersen, R.A. (Ed). Algal culturing techniques. Elsevier Academic Press and Phycological Society of America, Massachusetts, USA, pp 269-286 


\section{TABLES}

Table 1. List of strains that were isolated in this study, isolation location, date of isolation and size range. Tentative names are based on scanning electron microscopy (SEM) for M. cf. moniliformis. SEM and genome sequencing were used to identify Chaetoceros sp.

\begin{tabular}{|c|c|c|c|c|}
\hline $\begin{array}{l}\text { Strain } \\
\text { Number }\end{array}$ & Tentative Species Name & $\begin{array}{l}\text { Isolation } \\
\text { Location }\end{array}$ & $\begin{array}{l}\text { Date of } \\
\text { Isolation }\end{array}$ & Size $(\mu \mathrm{m})$ \\
\hline $\mathrm{Kb} 2-6$ & Melosira cf. moniliformis & $\begin{array}{l}\text { Wanggu } \\
\text { River Estuary }\end{array}$ & June 2013 & $10.6-26.9$ \\
\hline $\mathrm{Kb} 1-2$ & Chaetoceros sp. & Kendari Bay & $\begin{array}{l}\text { August } \\
2013\end{array}$ & $4.5-11.8$ \\
\hline $\mathrm{Kb} 1-3$ & Unidentified & $\begin{array}{l}\text { Wanggu } \\
\text { River Estuary }\end{array}$ & $\begin{array}{l}\text { August } \\
2013\end{array}$ & $1.2-10.0$ \\
\hline $\mathrm{Kb} 1-5$ & Unidentified & $\begin{array}{l}\text { Wanggu } \\
\text { River Estuary }\end{array}$ & $\begin{array}{l}\text { August } \\
2013\end{array}$ & $1.9-5.8$ \\
\hline
\end{tabular}

Table 2. Size ranges (mean $\pm \mathrm{SE}$ ) of cultured microalgae at each salinity tested. Numbers with common superscripts in a row are not significantly different from each other. $\mathrm{SE}=$ standard error of the mean from 50 sampled live cells.

\begin{tabular}{|c|c|c|c|c|c|c|}
\hline \multirow{2}{*}{ Strain } & \multirow{2}{*}{$\begin{array}{l}\text { Size } \\
\text { Measured }\end{array}$} & \multicolumn{4}{|c|}{ Size $(\mu \mathrm{m})$ at different salinity $(\mathrm{psu})$} & \multirow[t]{2}{*}{ p-value } \\
\hline & & 20 & 25 & 30 & 35 & \\
\hline Kb1-2 & Length & $4.9-9.5$ & $4.5-9.4$ & $5.5-11.8$ & $5.0-10.6$ & \\
\hline (Chaetoceros sp.) & Mean & $6.6 \pm 0.02^{\mathrm{a}}$ & $6.1 \pm 0.02^{\mathrm{a}}$ & $7.3 \pm 0.03^{\mathrm{b}}$ & $6.6 \pm 0.03^{\mathrm{a}}$ & 0.0001 \\
\hline \multirow[t]{2}{*}{$\mathrm{Kb} 1-3$} & Diameter & $2.0-8.5$ & $2.3-10.0$ & $2.3-9.6$ & $1.2-9.4$ & \\
\hline & Mean & $8.5 \pm 0.03^{b}$ & $5.2 \pm 0.05^{\mathrm{a}}$ & $5.3 \pm 0.05^{\mathrm{a}}$ & $4.3 \pm 0.05^{\mathrm{ab}}$ & 0.0067 \\
\hline \multirow[t]{2}{*}{ Kb1-5 } & Diameter & $3.1-5.8$ & $2.5-5.8$ & $2.3-5.6$ & $3.1-5.4$ & \\
\hline & Mean & $3.8 \pm 0.01^{\mathrm{a}}$ & $4.0 \pm 0.02^{\mathrm{a}}$ & $3.9 \pm 0.01^{\mathrm{a}}$ & $3.7 \pm 0.01^{\mathrm{a}}$ & 0.2278 \\
\hline \multirow[t]{2}{*}{ C. neogracile } & Length & $6.7-11.0$ & $4.0-8.7$ & $5.6-8.0$ & $5.8-10.7$ & \\
\hline & Mean & $8.0 \pm 0.02^{\mathrm{a}}$ & $5.4 \pm 0.02^{\mathrm{b}}$ & $6.6 \pm 0.02^{\mathrm{c}}$ & $7.5 \pm 0.02^{\mathrm{d}}$ & $<0.0001$ \\
\hline \multirow[t]{2}{*}{ T. chui } & Diameter & $7.3-12.5$ & $10.0-15.6$ & $10.8-16.6$ & $7.8-13.4$ & \\
\hline & Mean & $9.8 \pm 0.03^{b}$ & $12.6 \pm 0.03^{\mathrm{a}}$ & $12.5 \pm 0.03^{\mathrm{a}}$ & $10.2 \pm 0.03^{b}$ & $<0.0001$ \\
\hline \multirow[t]{2}{*}{ Ti. lutea } & Diameter & $4.6-6.5$ & $4.1-6.0$ & $3.7-6.4$ & $4.0-7.0$ & \\
\hline & Mean & $5.2 \pm 0.01^{\mathrm{a}}$ & $4.8 \pm 0.01^{\mathrm{b}}$ & $4.6 \pm 0.01^{\mathrm{b}}$ & $5.2 \pm 0.01^{\mathrm{a}}$ & $<0.0001$ \\
\hline
\end{tabular}


Table 3. Yield of cultured microalgae (mean $\pm \mathrm{SE}$ ) in $10^{6}$ cells $\mathrm{mL}^{-1}$ during stationary phase at different salinities. Numbers in a row with common superscripts are not significantly different from each other. $\mathrm{SE}=$ standard error of the mean from 8 points at

\begin{tabular}{llllll}
\hline Strain & \multicolumn{4}{c}{ Yield (mean \pm SE) at different salinity $(\mathrm{psu})$} & p-value \\
& 20 & 25 & 30 & 35 & \\
\hline $\begin{array}{l}\text { Kb1-2 } \\
\text { Chaetoceros } \mathrm{sp} .)\end{array}$ & $2.3 \pm 0.2^{\mathrm{a}}$ & $0.6 \pm 0.03^{\mathrm{c}}$ & $1.8 \pm 0.2^{\mathrm{ab}}$ & $1.7 \pm 0.1^{\mathrm{b}}$ & $<.0001$ \\
& & & & & \\
Kb1-3 & $3.7 \pm 0.1^{\mathrm{b}}$ & $4.4 \pm 0.1^{\mathrm{b}}$ & $3.8 \pm 0.1^{\mathrm{b}}$ & $6.5 \pm 0.1^{\mathrm{a}}$ & $<.0001$ \\
Kb1-5 & $3.3 \pm 0.3^{\mathrm{a}}$ & $1.6 \pm 0.1^{\mathrm{b}}$ & $2.4 \pm 0.4^{\mathrm{ab}}$ & $2.5 \pm 0.1^{\mathrm{ab}}$ & 0.02 \\
C. neogracile & $1.0 \pm 0.04^{\mathrm{a}}$ & $1.0 \pm 0.05^{\mathrm{a}}$ & $1.0 \pm 0.04^{\mathrm{a}}$ & $1.2 \pm 0.05^{\mathrm{a}}$ & 0.27 \\
T. chui & $0.4 \pm 0.01^{\mathrm{a}}$ & $0.3 \pm 0.02^{\mathrm{a}}$ & $0.6 \pm 0.01^{\mathrm{a}}$ & $0.7 \pm 0.03^{\mathrm{a}}$ & 0.5 \\
Ti. lutea & $1.1 \pm 0.01^{\mathrm{b}}$ & $1.5 \pm 0.02^{\mathrm{ab}}$ & $1.3 \pm 0.03^{\mathrm{ab}}$ & $1.6 \pm 0.04^{\mathrm{a}}$ & 0.02 \\
\hline
\end{tabular}

13 and 15 days of culture.

Table 4. Final weight (dry weight, $\mathrm{DW} \pm \mathrm{SE}$, and ash free dry weight, $\mathrm{AFDW} \pm \mathrm{SE}$ ) in $\mu \mathrm{g} \cdot \mathrm{mL}^{-1}$ after 15 days of culture of Indonesian microalgal strains, C. neogracile, T. chui and Ti. lutea at different salinity. Numbers in a row with common superscripts are not significantly different from each other. SE=standard error of the mean from 4 replicates

\begin{tabular}{|c|c|c|c|c|c|c|}
\hline \multirow[t]{2}{*}{ Strain } & \multirow{2}{*}{$\begin{array}{l}\text { Final } \\
\text { Weight }\end{array}$} & \multicolumn{4}{|c|}{ Weight at different salinity (psu) } & \multirow[t]{2}{*}{ p-value } \\
\hline & & 20 & 25 & 30 & 35 & \\
\hline Kb1-2 & DW & $175 \pm 6^{\mathrm{ab}}$ & $107 \pm 25^{\mathrm{b}}$ & $227 \pm 36^{\mathrm{ab}}$ & $283 \pm 51^{\mathrm{a}}$ & 0.02 \\
\hline (Chaetoceros sp.) & AFDW & $135 \pm 9^{\mathrm{ab}}$ & $85 \pm 11^{\mathrm{b}}$ & $184 \pm 23^{\mathrm{a}}$ & $204 \pm 33^{\mathrm{a}}$ & 0.008 \\
\hline \multirow[t]{2}{*}{ Kb1-3 } & DW & $20 \pm 6^{\mathrm{a}}$ & $46 \pm 9^{a}$ & $31 \pm 10^{\mathrm{a}}$ & $29 \pm 8^{a}$ & 0.19 \\
\hline & AFDW & $32 \pm 5^{\mathrm{a}}$ & $48 \pm 8^{\mathrm{a}}$ & $37 \pm 7^{\mathrm{a}}$ & $40 \pm 11^{\mathrm{a}}$ & 0.56 \\
\hline \multirow[t]{2}{*}{ Kb1-5 } & DW & $72 \pm 16^{\mathrm{a}}$ & $35 \pm 14^{\mathrm{a}}$ & $83 \pm 24^{\mathrm{a}}$ & $27 \pm 7^{\mathrm{a}}$ & 0.08 \\
\hline & AFDW & $2 \pm 8^{\mathrm{a}}$ & $32 \pm 16^{\mathrm{a}}$ & $3 \pm 6^{\mathrm{a}}$ & $18 \pm 5^{\mathrm{a}}$ & 0.15 \\
\hline \multirow[t]{2}{*}{ C. neogracile } & DW & $40 \pm 5^{\mathrm{b}}$ & $21 \pm 10^{\mathrm{b}}$ & $42 \pm 10^{\mathrm{b}}$ & $151 \pm 3^{\mathrm{a}}$ & $<0.0001$ \\
\hline & AFDW & $49 \pm 5^{\mathrm{bc}}$ & $29 \pm 7^{\mathrm{c}}$ & $56 \pm 6^{\mathrm{b}}$ & $97 \pm 5^{\mathrm{a}}$ & $<0.0001$ \\
\hline \multirow[t]{2}{*}{ T. chui } & DW & $640 \pm 311^{\mathrm{a}}$ & $414 \pm 264^{\mathrm{a}}$ & $757 \pm 363^{\mathrm{a}}$ & $147 \pm 32^{\mathrm{a}}$ & 0.44 \\
\hline & AFDW & $521 \pm 382^{\mathrm{a}}$ & $289 \pm 118^{a}$ & $179 \pm 42^{\mathrm{a}}$ & $144 \pm 20^{\mathrm{a}}$ & 0.56 \\
\hline \multirow[t]{2}{*}{ Ti. lutea } & DW & $35 \pm 15^{c}$ & $21 \pm 9^{c}$ & $209 \pm 7^{\mathrm{a}}$ & $131 \pm 19^{b}$ & $<0.0001$ \\
\hline & AFDW & $42 \pm 8^{\mathrm{b}}$ & $29 \pm 5^{\mathrm{b}}$ & $64 \pm 6^{\mathrm{b}}$ & $141 \pm 20^{\mathrm{a}}$ & $<0.0001$ \\
\hline
\end{tabular}


Table 5. Regardless salinity, size in $\mu \mathrm{m}$, yield in $10^{6}$ cells $\mathrm{mL}^{-1}$, division rate (k), dry weight (DW) and ash free dry weight (AFDW) in $\mu \mathrm{g} \mathrm{mL}^{-1}$ of Indonesian microalgal strains, C. neogracile, T. chui and Ti.lutea. All values are mean $\pm \mathrm{SE}$ from 50 replicates for size, 8 replicates for yield and 4 replicates for k, DW and AFDW

\begin{tabular}{llllllll}
\hline $\begin{array}{l}\text { Strain/ } \\
\text { Variables }\end{array}$ & $\begin{array}{l}\text { Kb1-2 } \\
\text { (Chaetoceros } \text { sp. })\end{array}$ & Kb1-3 & Kb1-5 & C. neogracile & T. chui & Ti.lutea & p-value \\
\hline Size & $6.7 \pm 0.1^{\mathrm{b}}$ & $4.7 \pm 0.2^{\mathrm{c}}$ & $3.8 \pm 0.05^{\mathrm{d}}$ & $6.9 \pm 0.1^{\mathrm{b}}$ & $11.3 \pm 0.1^{\mathrm{a}}$ & $5.0 \pm 0.1^{\mathrm{c}}$ & $<.0001$ \\
Yield & $1.6 \pm 1.3^{\mathrm{c}}$ & $4.6 \pm 2.6^{\mathrm{a}}$ & $2.5 \pm 2.1^{\mathrm{b}}$ & $1.1 \pm 0.4^{\mathrm{dc}}$ & $0.6 \pm 0.7^{\mathrm{d}}$ & $1.4 \pm 0.7^{\mathrm{c}}$ & $<.0001$ \\
k & $0.9 \pm 0.04^{\mathrm{dc}}$ & $1.0 \pm 0.07^{\mathrm{bcd}}$ & $1.4 \pm 0.04^{\mathrm{a}}$ & $1.1 \pm 0.1^{\mathrm{abc}}$ & $1.3 \pm 0.05^{\mathrm{ab}}$ & $0.8 \pm 0.03^{\mathrm{d}}$ & $<.0001$ \\
AFDW & $152 \pm 15^{\mathrm{ab}}$ & $39 \pm 4^{\mathrm{b}}$ & $14 \pm 5^{\mathrm{b}}$ & $58 \pm 7^{\mathrm{b}}$ & $283 \pm 98^{\mathrm{a}}$ & $69 \pm 13^{\mathrm{b}}$ & $<.0001$ \\
\hline
\end{tabular}




\section{FIGURE LEGENDS}

Figure 1. Diagram of microalgae culture sampling for one strain at four salinity levels $(20,25,30$ and $35 \mathrm{psu})$ tested in four replicates. One arrow describes volumes retrieved for growth analysis. The rest of the culture volume was harvested for subsequent biochemical composition (paper in preparation) of the algae.

Figure 2. Scanning electron micrographs of microalgal isolates in this study. Kb2-6 identified as the chain-forming Melosira cf. moniliformis (a), and Kb1-2 that belongs to Chaetoceros sp. (b).

Figure 3. Photomicrographs of Indonesian microalgae strains denoted as Kb1-3 (a) and Kb1-5 (b) at 40x magnification using light microscopy. Scale bar is $50 \mu \mathrm{m}$.

Figure 4. Increase in cell density of Indonesian microalgae Chaetoceros sp., Kb1-3, Kb1-5 (a, b, c, respectively) over culture period compared to C. neogracile, T. chui and Ti. lutea (d, e, f, respectively) at different salinities in psu. Standard error about the mean are represented by error bars from 4 replicates. Note that the y axes are not all on the same scale.

Figure 5. Division rate $\left(\mathrm{k}\right.$, doubling.day $\left.{ }^{-1}\right)$ of cultured microalgae at different salinities, 20 25, 30 and 35 psu, during logarithmic phase of growth. Log phase was at time intervals of 0 to 3 days for $\mathrm{Kb} 1-2, \mathrm{~Kb} 1-5$ at all salinities tested, Kb1-3 at 25 psu and $C$. neogracile at 20, 25 and 30. Log phase of C. neogracile cultured at 35 psu was at time intervals of 6 to 8 days. Log phase was at time intervals of 3 to 6 days for $T$. chui at all salinity levels and Kb1-3 at 20, 30 and 35 psu, 6 to 8 days for Ti. lutea cultured at 25 and 30 psu and 8 to 10 days at 20 and 35 psu. Standard error about the mean are represented by error bars from 4 replicates. 
Figure 1.

Every other day:

- Cell density (3 mL)

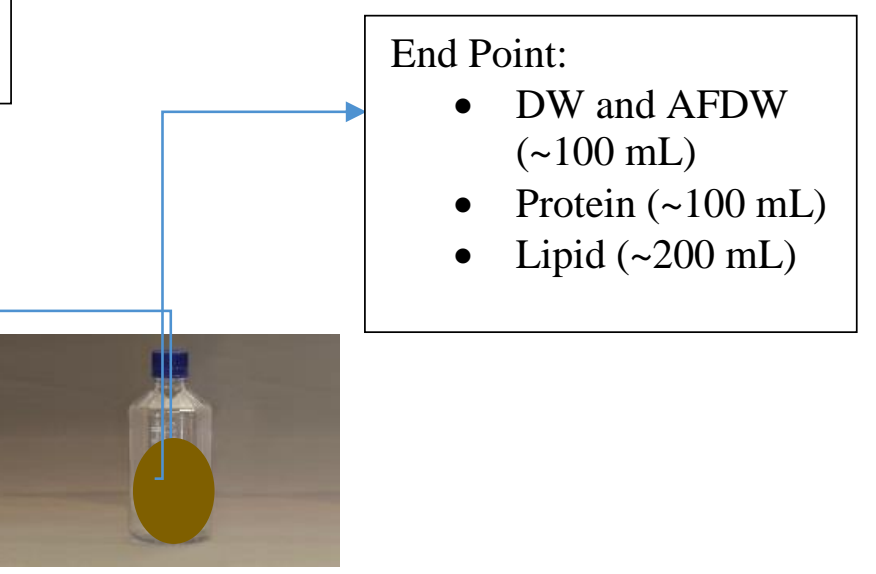


Figure 2.
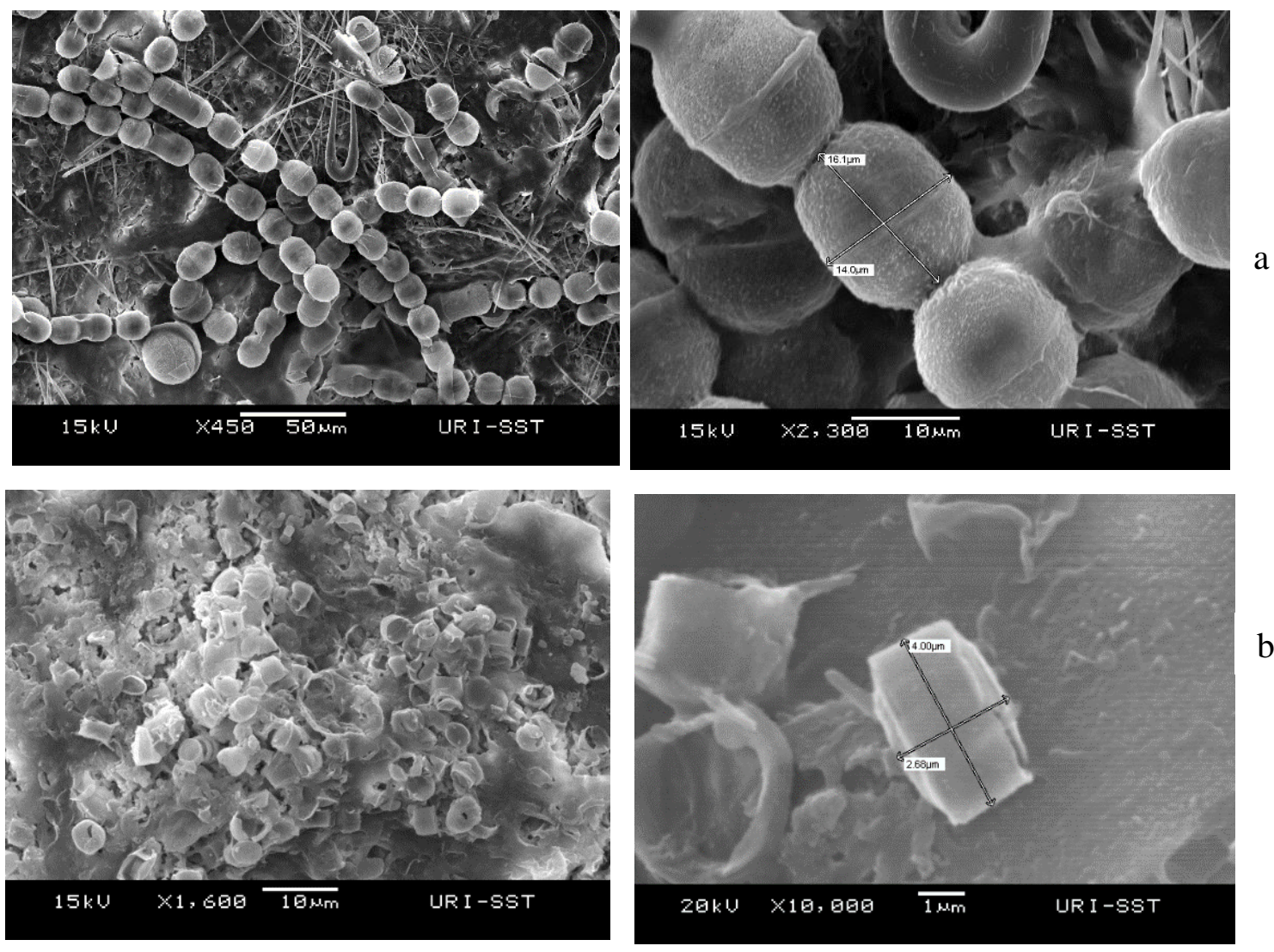
Figure 3
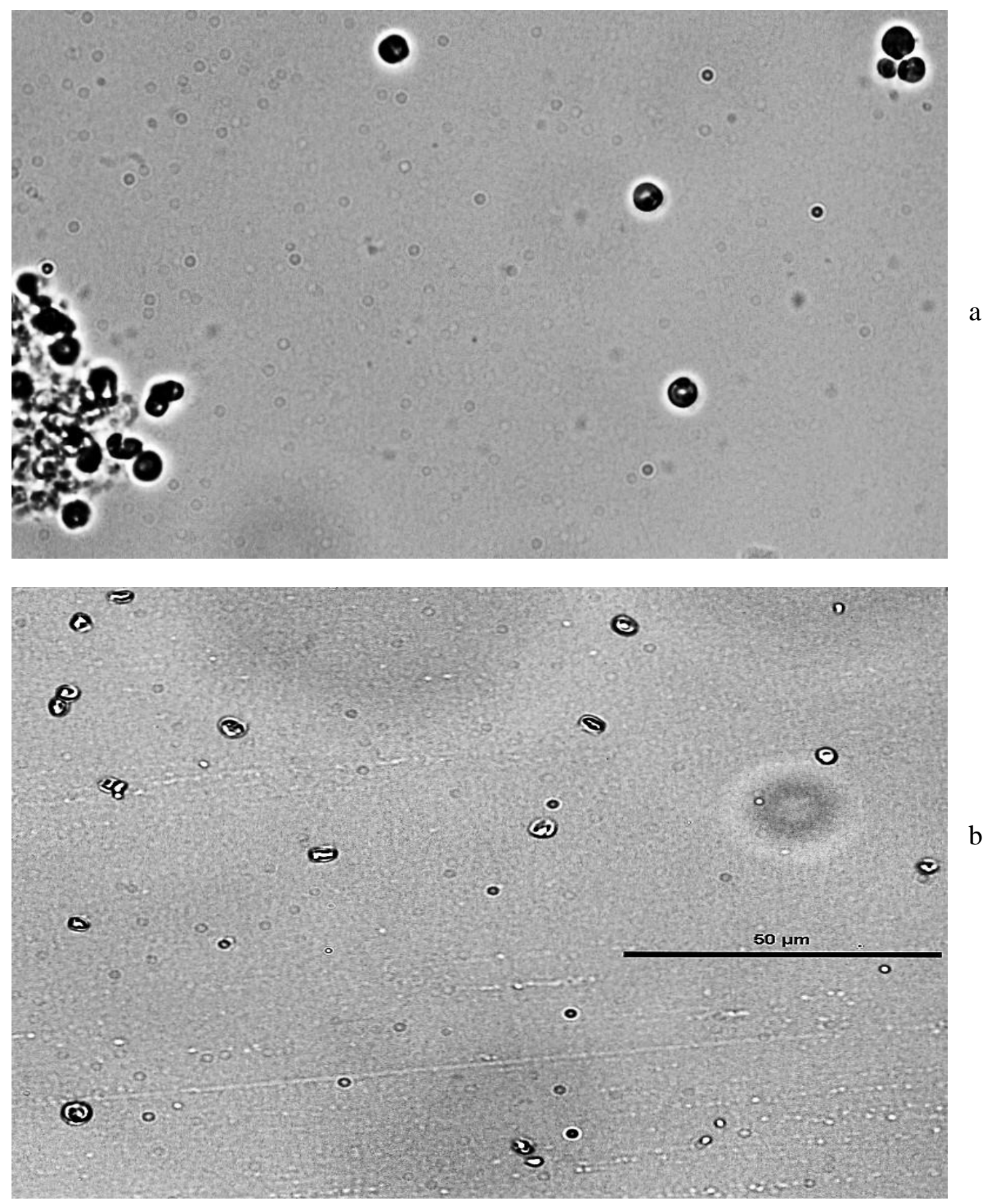
Figure 4

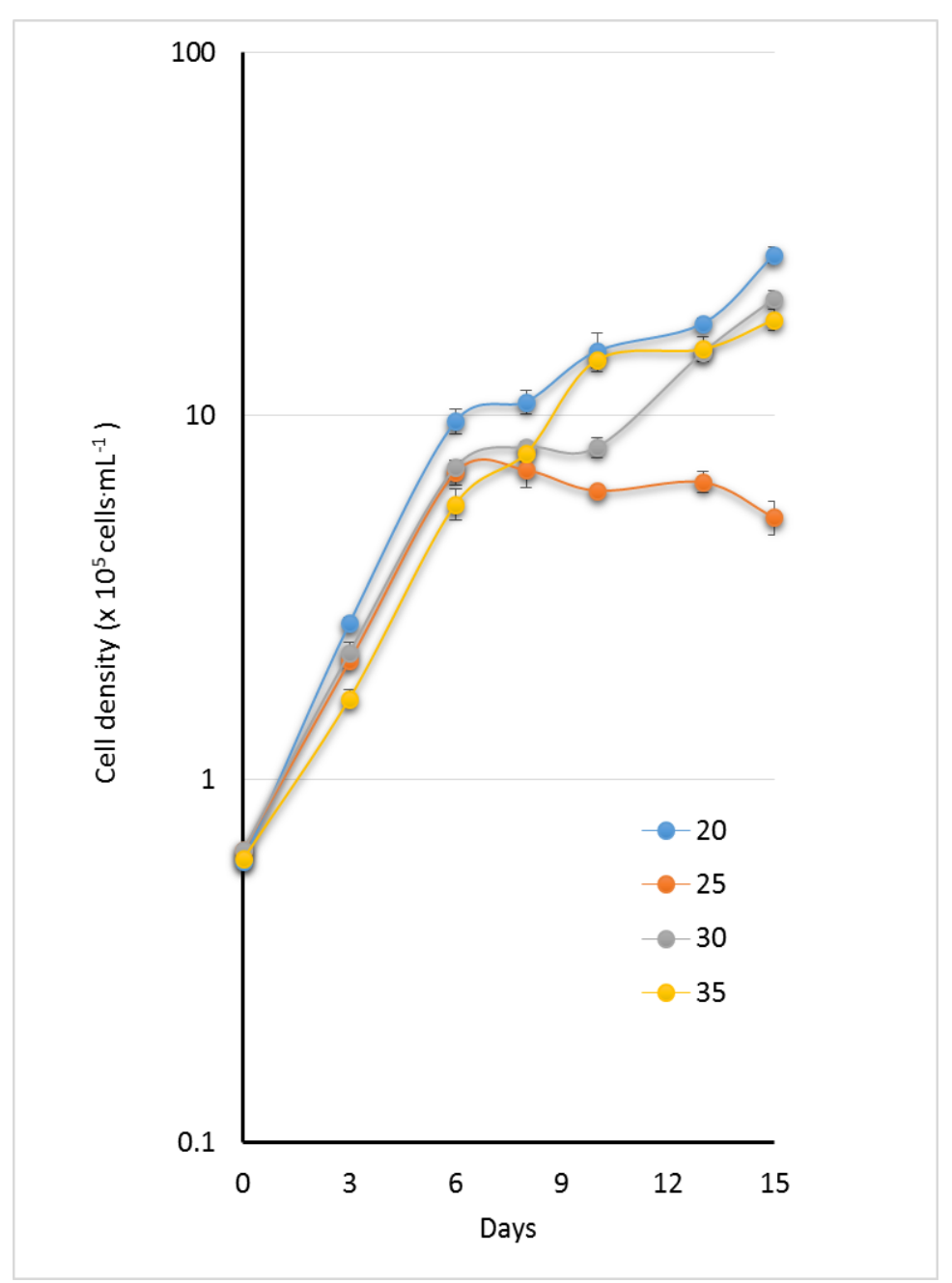

a

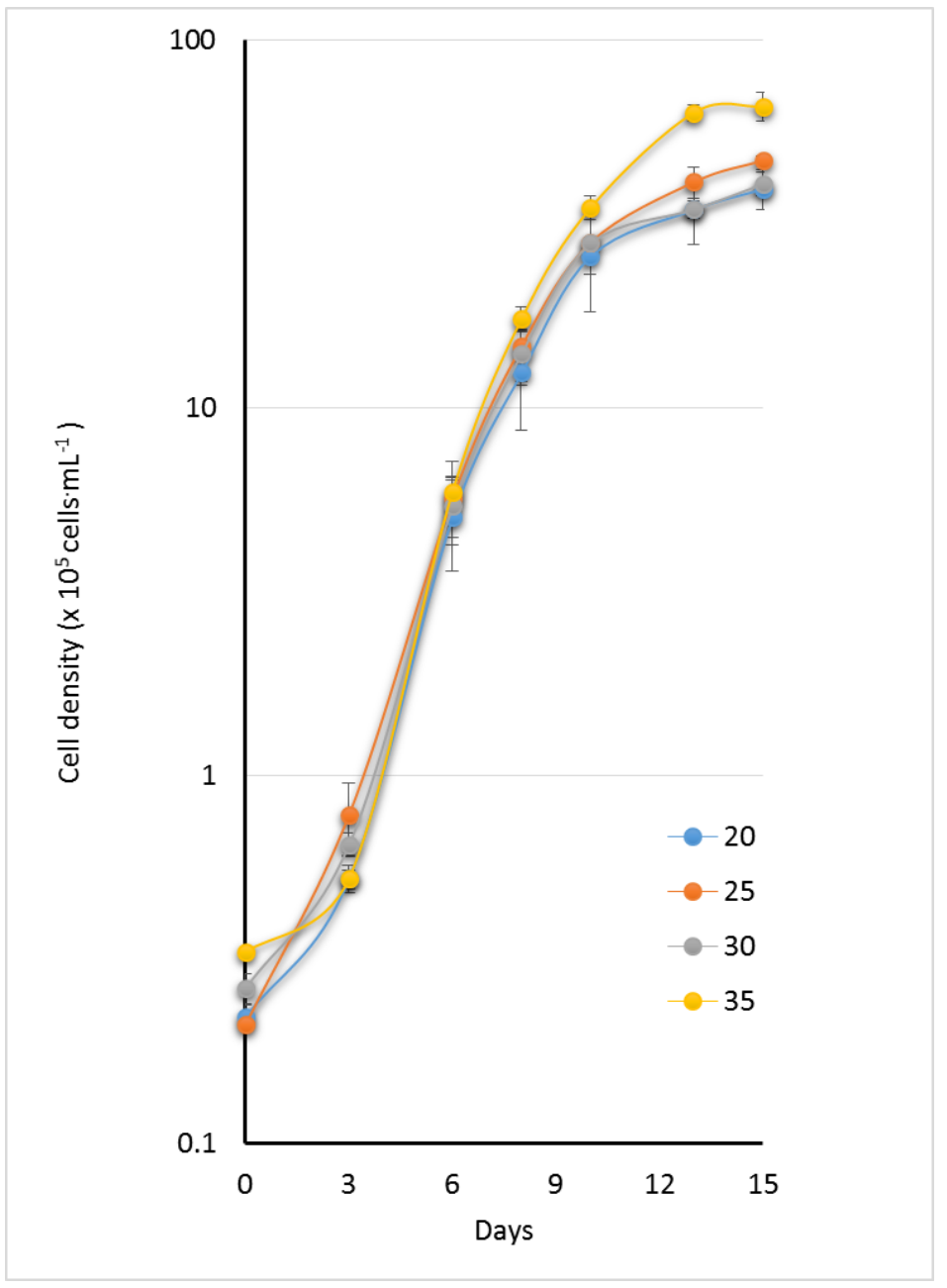

b 

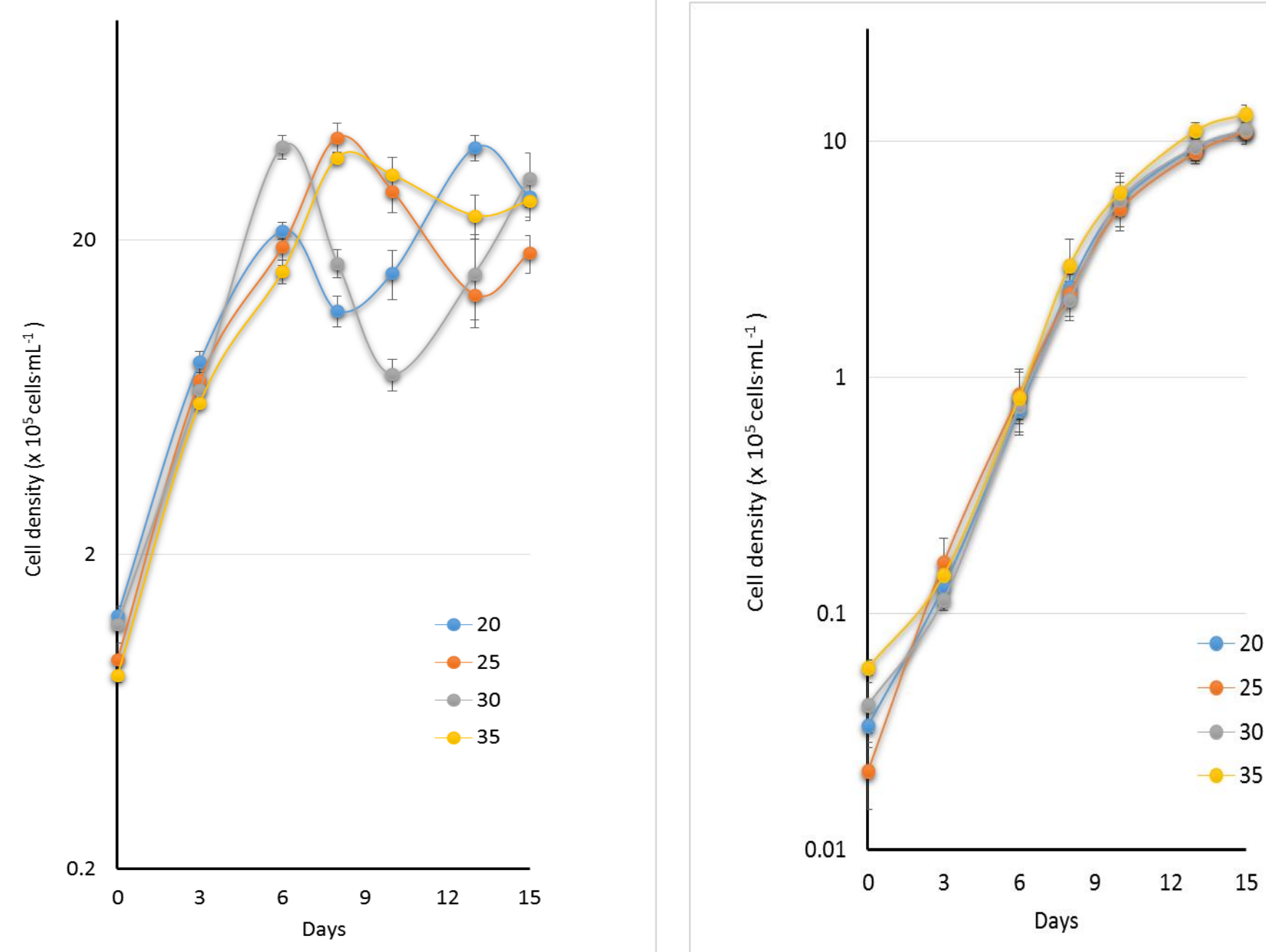

c 

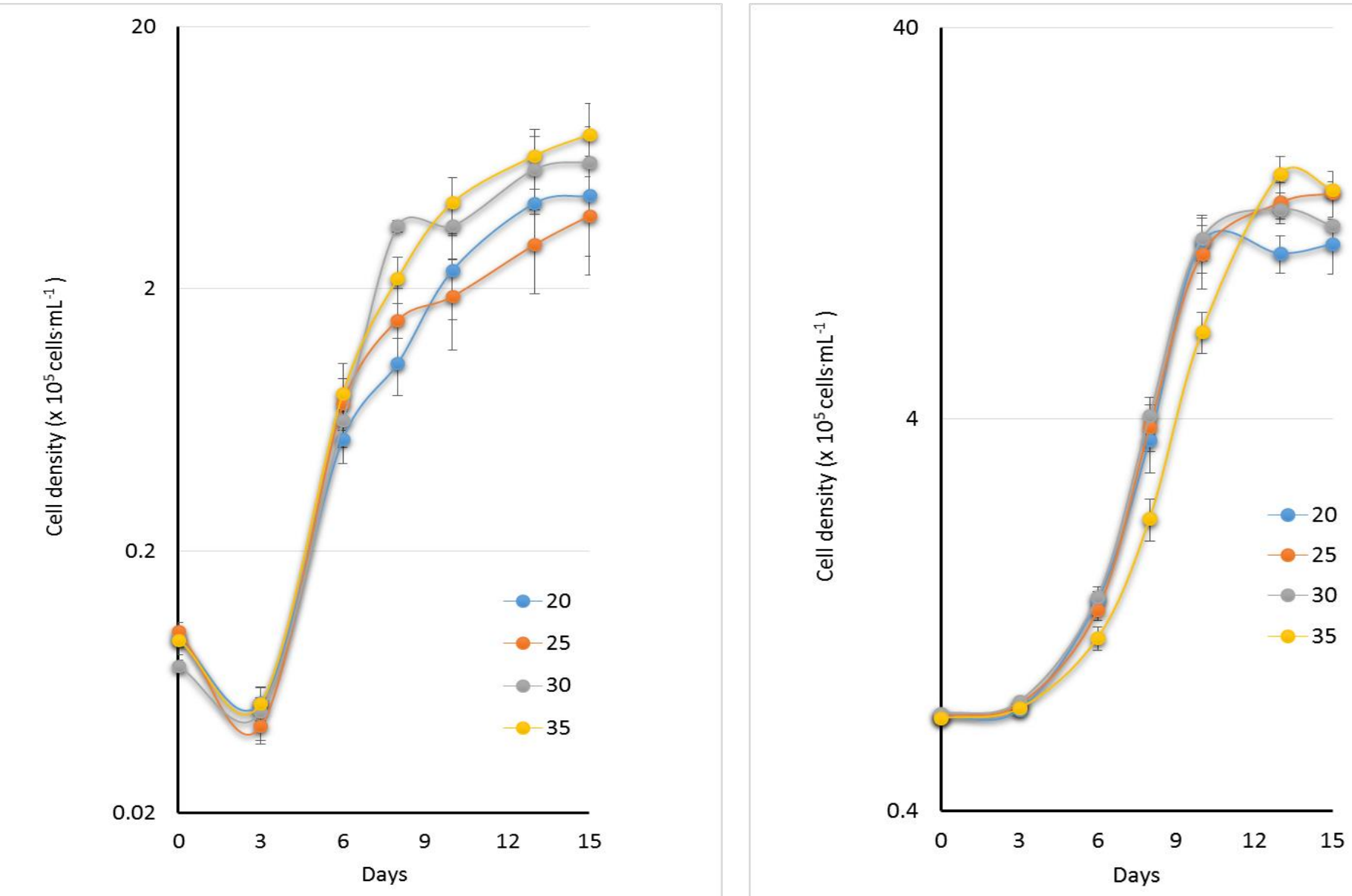
Figure 5

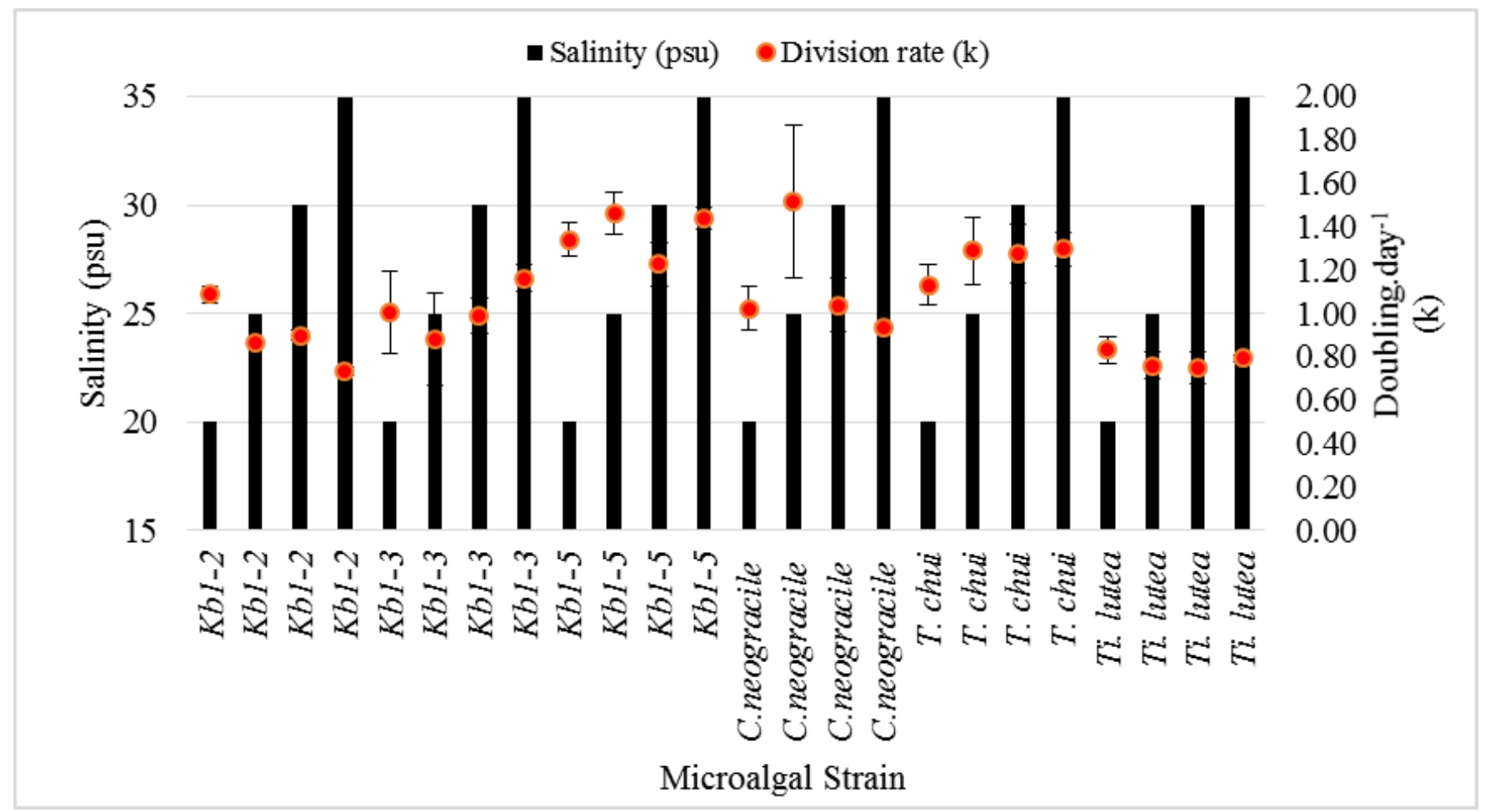




\title{
CHAPTER 3
}

\section{Effects of salinity on growth and nutritional content of newly isolated Indonesian microalgal strains with potential for use in shrimp hatcheries}

\author{
By \\ Wa Iba ${ }^{1,2^{*}}$, Lenore Martin ${ }^{4}$ Michael A. Rice ${ }^{1}$ And Gary H. Wikfors ${ }^{3}$ \\ ${ }^{1}$ Fisheries, Animal and Veterinary Sciences, University of Rhode Island, USA \\ 126 Woodward Hall, University of Rhode Island, Kingston, RI 02881. USA. \\ ${ }^{2}$ Faculty of Fisheries and Marine Science, University of Halu Oleo. \\ Kampus Hijau Bumi Tridharma Anduonohu Kendari, SE Sulawesi, 93232. Indonesia \\ ${ }^{3}$ Northeast Fisheries Science Center, NOAA Fisheries Service \\ 212 Rogers Avenue Milford, CT 06460 USA \\ ${ }^{4}$ Cell and Molecular Biology, University of Rhode Island. 131 Woodrard Hall, University of Rhode \\ Island, Kingston, RI 02881, USA
}

In preparation for submission to Journal of Aquaculture Research 


\section{Abstract}

A two-week batch experiment was conducted on three newly isolated Indonesian microalgal strains (Kb1-2 identified as Chaetoceros sp., Kb1-3 and Kb1-5) and Tisochrysis lutea to determine salinity effects upon the proximate composition and $\omega-3$, eicosapentaenoic acid and docosahexaenoic acid, (EPA and DHA) and $\omega-6$ (arachidonic acid/ARA). Salinity affected the total lipid content in Indonesian microalgal strains $(\mathrm{Kb} 13$, and $\mathrm{Kb1}-5, \mathrm{p}=0.03)$ except Chaetoceros sp. Total lipid content in Kb1-3 was significantly higher at 25 and 35 psu $(24.6 \pm 1.4$ and $12.9 \pm 0.3$ $\%$, respectively) compared to 30 and 25 psu ( $4.4 \pm 1.4$ and $4.9 \pm 0.5 \%$, respectively). Kb1-5 produced highest protein when cultured at 25 and 35 psu $(47.7 \pm 0.4$ and $38.8 \pm$ $0.8 \%$ ), decreasing at 20 and 30 psu to $26.2 \pm 2.4$ and $15.0 \pm 1.1 \%$, respectively. Salinity levels affected carbohydrate content of only one Indonesian microalgal strain (Chaetoceros sp., $\mathrm{p}=0.003$ ), but not Kb1-3 and Kb1-5. Carbohydrate content above $10 \%$ was observed in $\mathrm{Kb} 1-5$; whereas, in $\mathrm{Kb} 1-3$ the content ranged from 4-8\%. ARA, EPA and DHA were not detected at 20 psu in Chaetoceros sp and at 35 psu in Kb1-5. EPA and DHA were not detected at all salinities tested in Kb1-3. ARA was absent in T. lutea at all salinities tested. DHA content of Indonesian strains was similar to $T$. lutea. Higher percentage of ARA to total fatty acids was found in $\mathrm{Kb} 1-3$, ranging from 2.42-7.90\% $(\mathrm{p}=0.0008)$. EPA was higher in T. lutea, ranging from $1.31-13.16 \%$ of total fatty acids and it was similar to Indonesian strains, Kb1-5 ( $\mathrm{p}=0.03)$. Lipid, protein and carbohydrate in Indonesian strain were within the range required for shrimp larvae suggesting that they may be potential to be used in shrimp hatcheries.

Keywords: Microalgae, nutrition, fatty acids, shrimp 


\section{Introduction}

Local isolates of microalgae from different geographic locations have been investigated for use in various applications, including aquaculture, biofuel or bioproducts and bioremediation, with promising results (Brown et al., 1997; Renaud et al., 1999; Matsunaga et al., 1999; Nuñez et al., 2002; Yeesang and Cheirsilp, 2011; Talebi et al., 2011; Cai et al., 2013; Borowitzka, 2013; Ruangsomboon et al., 2013; Durvasula et al., 2015; Hende et al., 2016). In aquaculture, many cultured animals utilize live microalgae at certain life-history stages -- all growth stages of bivalve mollusks, and during larval stages of some fish and crustaceans -- underscoring the importance of microalgae in the aquaculture industry. In shrimp aquaculture in particular, the co-culture practice of microalgae and shrimp throughout or in some part of their growth cycle has resulted in significantly better growth and survival of the cultured species (Nuñes et al., 2011; Sanchez et al., 2012; Iba et al., 2014; ; Cao et al., 2014; Jamali et al., 2015).

The quality of microalgae as live food in aquaculture hatcheries is determined by several factors including: appropriate size, digestibility, robust growth under variable culture conditions, and above all, appropriate nutritional content (Brown, 2002). In general, microalgae can be considered good candidates for shrimp aquaculture if they contain protein higher than $25 \%$ of dry weight, $8-30 \%$ carbohydrate, and approximately 10\% lipid (Tobias-Quinitio and Villegas, 1982). Usually, species with high fatty-acid content, particularly including eicosapentaenoic acid (EPA), docosahexaenoic acid (DHA), and arachidonic acid (ARA), are the most desirable for shrimp aquaculture

(Coutteau, 1996; Nuñez et al., 2002). Furthermore, cholesterol also is considered to be 
an essential nutrient for shrimp; therefore, adequate cholesterol or metabolizable phytosterols is another desirable trait for microalgae to be used in shrimp aquaculture (Teshima et al., 1982; Lim, 1998; D’Souza and Loneragan, 1999).

Culture productivity and nutritional content of microalgae can vary based upon nutrients in culture medium and environmental conditions such as light intensity, temperature, and salinity (Renaud et al., 2002; de Castro Araujo et al., 2005; Schwenk et al., 2013). Salinity has been known to affect the lipid, protein and carbohydrate content of various species of microalgae, with different optimal ranges for different species (Renaud and Parry, 1994; de Castro Araujo et al., 2005; Khatoon et al., 2010; Zhila et al., 2011; Ruangsomboon et al., 2013). The present study was done to investigate the nutritional contents of newly isolated microalgae from Kendari Bay and the Wanggu River Estuary in South East Sulawesi, Indonesia under different salinity culture conditions. These two habitats are considered to be good potential sources of microalgae for use in regional white shrimp (Litopenaeus vannamei) hatcheries.

\section{Material and Methods}

\subsection{Algal Culture}

Three distinct microalgal isolates from Kendari Bay, denoted as Kb1-2 (Chaetoceros sp.), Kb1-3, and Kb1-5, were studied, and Tisochrysis lutea (T-ISO; CCMP-1324) was used as a comparison species. All microalgal strains have been cultured and maintained at the University of Rhode Island (URI) for more than a year. All four strains of microalgae were cultured in duplicate for 15 days in $1,000-\mathrm{mL}$ Erlenmeyer culture flasks containing $600 \mathrm{~mL}$ of $\mathrm{f} / 2$ Guillard medium in artificial seawater at $28-29^{\circ} \mathrm{C}$ under 12:12 light: dark photoperiod at four different salinities: 20 , 
25, 30 and 35 practical salinity units (PSU) and under 160-170 $\mu$ mol photons $\mathrm{m}^{-2} \mathrm{~s}^{-1}$

PAR. Procedures of obtaining microalgal cell weight and measuring growth were described elsewhere (Chapter 2).

Microalgal cultures were harvested after two weeks of growth by filtering the algae onto pre-combusted $\left(100^{\circ} \mathrm{C}, 1 \mathrm{~h}\right)$, pre-weighed, $47-\mathrm{mm} \mathrm{GF} / \mathrm{F}$ Whatman filters prior to analysis. Pre-combusted filters were stored in a vacuum desiccator over a $\mathrm{KMnO}_{4}$ dessiccant before being used for sample filtration. Respective volumes of cultured microalgae (Table 1) at each salinity were filtered onto pre-weighed, precombusted filters, and rinsed with $10 \mathrm{~mL}$ 0.65-M ammonium formate to eliminate salts. Filters were oven dried at $100 \pm 5^{\circ} \mathrm{C}$ for $1 \mathrm{~h}$, placed overnight over $\mathrm{KMnO}_{4}$ salts in a vacuum desiccator, and weighed to obtain dry weight of the algae. Dry weight of microalgae was calculated using the following equations:

$$
\text { DW }(\mathrm{mg})=\text { Weight of filter with algae }- \text { weight of filter }
$$

All filters containing microalgal samples were folded and kept at $-20^{\circ} \mathrm{C}$ if not dried immediately. If not analyzed immediately, the dried microalgal samples were further kept at $-20^{\circ} \mathrm{C}$ up to 2 weeks before being subjected to biochemical analysis procedures (Gonzalez-Araya et al., 2011; Mohameini et al., 2012).

\subsection{Nutritional Analyses}

Total lipid, protein and carbohydrate contents of microalgae were analyzed based upon methods by Gonzalez-Araya et al (2012), Huang (2013) and Mohameini et al. (2012) from filtered and dried microalgal samples. Total lipid of the dried microalgae was extracted with chloroform-methanol-deionized water $(2: 1: 0.8, \mathrm{v} / \mathrm{v})$ according to the modified method of Bligh and Dyer (1959) as suggested by Mohameini 
et al (2013). In brief, the microfiber filter holding cells from $200 \mathrm{~mL}$ of culture was crushed in a mortar and pestle after adding $4 \mathrm{~mL}$ of liquid nitrogen. The sample was extracted twice with fresh solvent mixture and centrifuged at 1,000-2,000 x $\mathrm{g}$ for 10 minutes or until a compact pellet was formed. The supernatant from samples was placed in a $20-\mathrm{mL}$ tube with a screw cap and left for $24 \mathrm{~h}$ in the dark at $-5^{\circ} \mathrm{C}$ for phase separation. The methanol/water layer on the top was removed with a very fine Pasteur pipette, then 6-8 drops of toluene were added to the chloroform layer to remove any small amount of remaining water. The chloroform layer was transferred to a dry and pre-weighed vial. After the toluene/water on the surface of the chloroform layer in the vial was carefully removed, the chloroform was evaporated using rotary evaporator. After evaporating, the lipid sample was kept in a vacuum dessicator over $\mathrm{KOH}$ pellets over night and then the vial was weighed using a 5 digit balance. The lipid content was measured gravimetrically and was calculated using the following equation:

$$
\text { Lipid }(\%)=\frac{W L}{W D A} x 100
$$

where, WL (mg) and WDA (mg) are the weights of the extracted lipid and the dry algae biomass, respectively (Huang et al, 2013; Mohameini et al, 2013).

The total protein contents of microalgae cultures were determined using the Lowry method as described by Mohameini et al (2013). After filtered samples were crushed with a mortar and pestle in liquid nitrogen, $10 \mathrm{~mL}$ of the Biuret reagent was added to the extracted sample, and $5 \mathrm{~mL}$ to tubes containing $5 \mathrm{~mL}$ protein standard, before they were placed in a heating block at $100 \pm 5^{\circ} \mathrm{C}$ for $60 \mathrm{~min}$. After the tubes were removed from the heating block, $0.5 \mathrm{~mL}$ of Folin-Phenol reagent was added immediately while mixing with a Vortex stirrer. The tubes were placed in a $100 \pm 5^{\circ} \mathrm{C}$ 
heating block for a further $20 \mathrm{~min}$ and finally allowed to equilibrate to room temperature for another $15 \mathrm{~min}$ before centrifuging at 1,000-2,000 x g for 5-10 min. Protein content of the supernatant was determined using spectrophotometry at $660 \mathrm{~nm}$ against bovine serum albumin (BSA) standard samples using the equation below:

$$
\text { Protein content }(\%)=\frac{\text { Psample }}{W d w} \times 100
$$

when, $\mathrm{P}_{\text {sample }}=$ milligrams of protein in samples against protein standard and $\mathrm{W}_{\mathrm{dw}}=$ total dry weight of the microalgae (mg).

The carbohydrate contents of microalgal samples were determined using a method described by Mohameini et al (2012), also known as the modified PhenolSulfuric Acid method. In brief, after adding $5 \mathrm{~mL} 1 \mathrm{M} \mathrm{H}_{2} \mathrm{SO}_{4}$, homogenized microalgal samples were incubated in a heating block at $100^{\circ} \mathrm{C}$ for $60 \mathrm{~min}$. The samples were centrifuged at 1,000-2,000 $\mathrm{xg}$ for 5-10 minutes after having been incubated for $\sim 30 \mathrm{~min}$ at room temperature. Two $\mathrm{mL}$ of supernatant were added to $1 \mathrm{~mL}$ of the phenol solution and mixed. After adding $5 \mathrm{~mL}$ concentrated $\mathrm{H}_{2} \mathrm{SO}_{4}$ and mixing again, the carbohydrate content was determined by spectrophotometry against a glucose standard curve at 485 nm. Carbohydrate content was calculated using the equation:

$$
\text { Carbohydrate content }(\%)=\frac{\text { Csample }}{W d w} \times 100
$$

when $\mathrm{C}_{\text {std }}=$ milligrams carbohydrate in sample based upon standard curve comparison and $\mathrm{W}_{\mathrm{dw}}=$ total dry weight of microalgae $(\mathrm{mg})$.

Total lipid extracts were collected to determine fatty acid compositions of the microalgae. Fatty acids within the lipid extracts were saponified after dilution in $2 \mathrm{~mL}$ of chloroform and addition of $1 \mathrm{~mL}$ of $3 \mathrm{~N} \mathrm{NaOH}$ before heating to $90^{\circ} \mathrm{C}$ for $1 \mathrm{~h}$. After cooling to room temperature, samples were neutralized using $1.8 \mathrm{~mL}$ of $3.6 \mathrm{~N} \mathrm{HCl}$ and 
reheated to $90^{\circ} \mathrm{C}$ for 10 minutes. Fatty acids from the membrane hydrolysate were extracted three times with $1 \mathrm{~mL}$ of a mixture of hexane:diethyl ether (1:1, v:v), and the organic layers were combined in an Erlenmeyer flask. The fatty-acid extract was dried overnight over anhydrous sodium sulfate with a cover before being filtered with regular filter paper (Whatman Grade 5, diameter $25 \mu \mathrm{m}$ ) into a round-bottom flask. The organic solvents were evaporated to dryness by rotary evaporator, and the fatty-acid hydrolysates were stored in a desiccator under argon at $-80^{\circ} \mathrm{C}$ before further transesterification. The fatty acid extracts were derivatized to fatty acid methyl esters (FAME) using $5 \mathrm{~mL}$ boron tri-fluoride-methanol complex $\left(\mathrm{BF} 3-2 \mathrm{CH}_{3} \mathrm{OH}\right)$ at $60^{\circ} \mathrm{C}$ for 5 min. C-12 (Lauric Acid) was used as an internal standard at $50 \mu \mathrm{g}$ for T. lutea and $150 \mu \mathrm{g}$ for Indonesian strains. After cooling at room temperature, $1 \mathrm{~mL}$ of water and 1 $\mathrm{mL}$ of hexane were added to the mixture. To transfer the esters into the non-polar solvent thoroughly, the vials were shaken vigorously. The upper organic/hexane layer was removed into aan Erlenmeyer flask. Those fatty acids methyl esters (FAME) were dried over anhydrous sodium sulfate overnight, filtered with filter paper (Whatman Grade 5, diameter $25 \mu \mathrm{m}$ ), and the solvent was evaporated by rotary evaporator. FAME samples were diluted in chloroform for gas chromatography - mass spectrometry (GCMS) analysis. If the samples were not analyzed immediately, they were stored in a dessicator under argon at $-80^{\circ} \mathrm{C}$. FAME mix (Supelco 37 Component FAME mix Sigma Aldrich USA) was used as a standard to identify ARA, EPA and DHA retention times by GC-MS.

Analysis of FAME prepared from lipid extracts was conducted using a GC-MS system with an Agilent gas chromatograph (6890 GC) in tandem with mass 
spectrometry (5973 MSD, Agilent Technologies/19091J-413, USA) with one uL of diluted samples run at an injector temperature of $250{ }^{\circ} \mathrm{C}$. An HP-5 capillary, fused silica, column (0.32 mm ID x $30 \mathrm{~m}$ x $0.25 \mu \mathrm{m}$ (5\%-Phenyl)-methylpolysiloxane film, equivalent to USP phase G27) was installed in the GC, with helium as the carrier gas. The GC outlet was connected to the mass spectrometer to ionize the samples, and the detector was scanned from $15-800 \mathrm{~m} / \mathrm{z}$ at $1.91 \mathrm{scans} / \mathrm{s}$. Extracted fatty acid methyl ester retention times in the total ion chromatograms were identified by comparison with peaks from the chromatograms of the Supelco FAME 37-fatty acid standard mix injected on the same day, and FAME identities were confirmed by matching relevant chromatographic peak fragmentation patterns with those of authentic standards in the NIST library database (NIST02.L). Quantification of fatty acids extracted from each microalgal strain was calculated based upon the relative ion abundance of the ${ }^{13} \mathrm{C}$-lauric acid methyl ester internal standard as follows:

$$
\frac{(\text { Area of fatty acid } / \text { Area of lauric acid }) \times \text { weight of lauric acid in sample }(\mu \mathrm{g})}{\text { Lipid weight }(\mathrm{mg})}
$$

\subsection{Statistical Analysis}

The effects of salinity on lipid, protein and carbohydrate content in each strain of microalgae were analyzed using one-way analysis of variance (ANOVA). One-way ANOVA was also used to compare ARA, EPA and DHA across microalgal strains. Percentage data were transformed using square root transformation to meet ANOVA normality assumptions. Significant differences in the data $(\mathrm{p}<0.05)$ were analyzed with pairwise multiple comparison of means (Tukey test). All statistical analyses were done in SAS Enterprise Guide 7.1. 


\section{Results}

\subsection{Microalgal growth}

Microalgal growth data and discussion was covered thoroughly in Chapter 2 of this dissertation. Most of strains cultured were harvested during onset of stationary or late stationary phase except Kb1-3 strain that was at late logarithmic phase of growth (Figure 4, Chapter 2).

\subsection{Proximate composition}

Proximate compositions of microalgal strains tested in this study varied with salinity. Lipid, protein, and carbohydrate contents of each strain are shown in Fig. 1. Salinity affected the total lipid content in Indonesian microalgal strains (Kb13, $\mathrm{p}=0.0005$ and $\mathrm{Kb} 1-5, \mathrm{p}=0.03$ ) except Chaetoceros $\mathrm{sp}$. Total lipid content in Kb1-3 was significantly higher at 25 and 35 psu $(24.6 \pm 1.4$ and $12.9 \pm 0.3 \%$, respectively $)$ compared to 30 and 25 psu (4.4 \pm 1.4 and $4.9 \pm 0.5 \%$, respectively). Kb1-5 showed a higher total lipid content at 20,25 and 30 psu but not atthanat 35 psu. Also, salinity affected the total lipid content of T. lutea which was approximately $20 \%$ at 30 and 35 psu compared to ca. $10 \%$ at 20 and 25 psu.

Protein content in all Indonesian strains was affected by culture salinity, similar to T. lutea. Similar protein contents were found in Chaetoceros sp. cultured at 20, 30 and $35 \mathrm{psu}(>30 \%)$ but not at 25 psu that was $19 \%(\mathrm{p}=0.0007)$. Protein content was significantly higher when microalgae were cultured at low (20 and $25 \mathrm{psu}$ ) salinity in the Kb1-3 strain, and protein decreased at higher salinities (30 and $35 \mathrm{psu}$ ), similar to $T$. lutea $(\mathrm{p}=0.03$ and 0.001 , respectively). Similar protein content was observed in $\mathrm{Kb} 1$ - 
5 cultured at both low (20 psu) and high (35 psu) salinity, with decreasing content found at 25 and $30 \mathrm{psu}(\mathrm{p}=0.0003)$

Salinity levels affected carbohydrate content of only one Indonesian microalgal strain (Chaetoceros sp., $\mathrm{p}=0.003$ ), but not $\mathrm{Kb} 1-3$ and Kb1-5. Carbohydrate content above $10 \%$ was observed in $\mathrm{Kb} 1-5$; whereas, in $\mathrm{Kb} 1-3$ the content ranged from $4-8 \%$. Chaetoceros sp. showed a higher level of carbohydrate at $25 \mathrm{psu}$, significantly different from all other salinities. Higher carbohydrate content was found at high salinity (35 psu) in T. lutea whereas at other salinities tested, carbohydrate content was similar $(\mathrm{p}=0.05)$.

\subsection{Fatty Acids}

Of Indonesian microalgae, Kb1-2 contained essential $\omega-3$ (EPA and DHA) and $\omega-6$ (ARA) fatty acids at 25 and 35 psu but they were not detected at 20 and 30 psu salinity tested. ARA, EPA and DHA were all detected at 35 psu in Kb1-3 strains and at 25 psu in KB1-5. EPA and DHA were not detected at 20, 25 and 30 psu in Kb1-3 (Table 1, Fig. 2). ARA was not detected in T. lutea in all salinities tested whereas EPA was absent at 25 psu. Regardless salinity, DHA content of Indonesian strains was similar to T. lutea. Higher percentage of ARA to total fatty acids was found in Kb1-3, ranging from 2.42-7.90\% $(\mathrm{p}=0.0008)$. ARA concentration in Indonesian strains, Kb1-2 and Kb1-5 was similar with T. lutea. $\quad$ EPA was higher in T. lutea, ranging from 1.31-13.16 $\%((\mathrm{p}=0.03)$ of total fatty acids and it was similar to Indonesian strains, Kb1-5. DHA and EPA to total fatty acids in T. lutea was in the range of $1.2-13.2 \%$ and $1.9-4.8 \%$, respectively (Fig. 2). 
Concentrations of fatty acids found in microalgal strains varied across salinity tested as shown in Table 1 and Appendix. The presence or absence of certain fatty acids in each microalgal strain varied with culture salinity; for instance, the short-chain, saturated fatty acid, pentanoic acid, (5:0) was present in Kb1-5 only when cultured at 20 and 30 psu and Kb1-3 at 30 and 35 psu; whereas, capric acid (10:0) was found only at 35 psu in Kb1-2 and at 25 and 35 psu in T. lutea. However, this fatty acid was found at all salinities tested in Kb1-5. The long-chain saturated fatty acid nervonic acid (23:0) was present only in T. lutea at 20 and 35 psu. Similarly, thelong-chain, saturated fatty acid, lignoceric acid (24:0) was found only in Kb1-3 cultured at 20, 25 and 35 psu and in $T$. lutea cultured at $35 \mathrm{psu}$. In general, Indonesian microalgal strains contained the short- and long-carbon chain fatty acids, both saturated such as caproic acid (6:0), caprylic acid (8:0), and tridecanoic acid (10:0), and monounsaturated such as palmitoleic (16:1 $\omega 7)$ and oleic acid (18:1 $\omega 9)$.

All Indonesian microalgal strains distinctively contained the dicarboxylic acid (DCA) phthalic acid, which was not present in T. lutea. In T. lutea, some short-carbonchain and saturated fatty acids such as pentanoic and capric acid were not present. $T$. lutea predominantly contained long-carbon-chain fatty acids, particularly at higher culture salinities tested (Table 1).

\section{Discussion}

Sufficient nutritional contents of microalgae determine efficacy as food for shrimp larvae in aquaculture hatcheries. Adequate levels of protein, lipid, and carbohydrate are particularly critical for normal growth and development of penaeid shrimp (Milamena, 1996; Nuñez, 2002; Gleccross, 2009). Our study showed that Indonesian microalgae, 
as well as $T$. lutea, during stationary phase contained protein higher than required by shrimp larvae (ca. 25\%), with comparable lipid and carbohydrate contents (around 10 and 5\%, respectively), as suggested by Tobias-Quinito and Villegas (1982).

Total lipid contents of two Indonesian microalgae (except Kb1-2) and T. lutea were affected by salinity. Kb1-3 contained lower lipid at 20 and 30 psu, and higher lipid contents were found at other salinity levels tested. Higher lipid was obtained at 20 and 25 psu as well, as at $30 \mathrm{psu}$, in Kb1-5, with 35 psu giving the lowest lipid content. This finding is in agreement with study by Khatoon et al (2014) and Ruangsomboon et al (2013) who found that Tetraselmis sp., Nannochloropsis sp., and a newly-isolated species of Scenedesmus dimorphus from Thailand responded differently to salinity in terms of lipid. Nannochloropsis sp. and Tetraselmis sp. showed significantly higher lipid contents at 30 psu compared to 20 and 40 psu salinities; whereas, S. dimorphus accumulated higher lipid at 5 psu salinity. Also, lipid content in the Chaetoceros sp. analyzed in the present study was comparable to lipid in Chaetoceros sp. isolated from Innisfail, Queensland, Australia, reported by Renaud et al. (1999), that was 17\% of dry weight.. Lipid content of T. lutea in the present study was higher compared to a study reported by Gorgonio et al. (2013), which was $10.54 \%$ during logarithmic phase of growth and similar with study by Huerlimann et al. (2010), which was $26.8 \%$ when cultured at seawater salinity and measured during the stationary phase of growth. Lipid content in microalgae was known to be affected by culture conditions, such as salinity, light intensity and temperature, as well as culture medium and growth phase (Renaud and Parry, 1994; Nalder et al, 2015). Nalder et al. (2015) found that total lipid increased almost two fold from $6.7 \pm 0.8 \mathrm{pg} / \mathrm{cell}$ during log phase to $13.2 \pm 1.2 \mathrm{pg} / \mathrm{cell}$ during late 
stationary phase. Higher lipid production at certain salinities in microalgae is suggested as a coping mechanism under unfavorable conditions to reserve energy until favorable conditions resume (Kalita et al., 2011; Talebi et al., 2013).

Salinity affected protein content in Indonesian strains of microalgae and T. lutea. Generally, higher protein content was observed at lower salinity in each strain tested, although some variation occurred in Chaetoceros sp., and Kb1-5. Protein contents in Indonesian microalgal strains presented here were comparable to protein contents reported by Renaud and Parry (1994) for Nannochloropsis oculata and Nitzschia frustulum cultured at similar salinity levels as this study and harvested at late log phase. Furthermore, Renaud et al. (1999) reported similar protein content in Chaetoceros sp. from Queenlsand, also harvested at late log phase, to protein content of Chaetoceros sp reported here. Unlike the recent study by Khatoon et al. (2014), who reported that Nannochloropsis sp. and Tetraselmis sp contained higher protein content (ca. 45\% of dry weight) at 30 psu when cultured under natural sunlight and harvested at logarithmic phase of growth, all Indonesian strains and T. lutea in this present study had lower protein contents at $30 \mathrm{psu}$. The protein content of T. lutea at 30 and 35 psu presented here at stationary phase is comparable to protein concentration of Isochrysis galbana reported by Fidalgo et al. (1998).

Carbohydrate contents in both Indonesian strains and $T$. lutea were also affected by the culture salinities. Among Indonesian strains, range of carbohydrate content was comparable to local strains from Australia as reported by Renaud et al (1999), but slightly lower than strains isolated from the South China Sea (Khatoon et al. 2014). Carbohydrate content of T. lutea presented here was comparable to Isochrysis galbana 
reported by Fidalgo et al. (1998). Nevertheless, our study and other studies summarized by Mata et al. (2010), suggested that the differences in biochemical composition in microalgae were not only determined by culture medium and conditions such as salinity but also by the differences in strain that may be attributed to genetic differences. Therefore this finding is a promising result for exploring other local microalgal strains because there will be a chance to find several good strains for various purposes.

Our study showed that Indonesian microalgae contained similar DHA concentration with T. lutea. One strain of Indonesian microalgae, Kb1-3, contained ARA in higher concentration compared to other strains. EPA was higher in T. lutea compared to Indonesiain microalgae but they contained almost complete profiles of fatty acids. This may be a factor that contributed to reasonable weight gain of shrimp larvae up to mysis stage when fed on Indonesian strains of microalgae (Chapter 4). These weight gains were comparable to a study by Piña et al (2006), although the survival of our shrimp was considerably lower. Survival rates of shrimp larvae fed Indonesian strains were similar to that of shrimp fed C. neogracile and Te. chui, with the exception of Kb1-2 (Chapter 4).

Shrimp larvae from the genus Penaeus and Litopaneus require long-chain, polyunsaturated fatty acids, particularly those of $\mathrm{C} 20$ and C22: $₫-3$ and $\omega-6$ compounds during metamorphosis to be able to survive this critical period and $₫-3$ continue to grow. Some species such as $P$. japonicus showed the ability to elongate and desaturate $18: 3$ ๑-3 to produce long chain PUFA during larval stages (Castell, 1982; Teshima et al. 1992; Coutteau et al. 1996; D’Souza and Loneragan, 1999; Glencross, 2009). The level of these compounds in microalgae varies based upon culture conditions such as salinity, 
although the results were contradictory as suggested by several studies. Several microalgal strains cultured at high salinity such as Dunaliella sp., Nannochloropsis sp., and Nannochloropsis frustulum showed low contents of polyunsaturated fatty acids (Xu and Beardall 1997; Hu and Gao 2006). Zhilla et al. (2011) suggested that salinity and growth phase may affect fatty-acid composition of microalgae in which polyunsaturated fatty acids were lower during the early phase of growth under high salinity but increased during late logarithmic and stationary phases. PUFA in T. lutea presented here was in agreement with findings of Ben-Amotz et al. (1985), who found that Isochrysis sp. cultured at high salinity contained high concentration polyunsaturated fatty-acid contents, but higher compared to Renaud and Parry (1994) who conversely found that these fatty acids in Isochrysis sp. decreased under high salinity culture conditions.

Another finding in the present study is the presence of Phthalic Acid in all Indonesian microalgal strains. Phthalic acid is a dicarboxylic acid that is usually found as an aerosol in the atmosphere (Mochida et al 2003) or as a product of diisobutyl phthalate (DiBP) hydrolysis catalised by the enzyme esterase (Ding et al, 2015). DiBP is one form of plasticizer phthalate esters (PAEs) that have become a public concern because of their effects on environmental contamination and toxicity in mammals (Ding et al, 2015). The C8 and C9 DCAs including phthalic acid have been proposed as oxidation products of unsaturated fatty acids such as oleic acid (Kawamura and Gagosian, 1987; Stephanou and Stratigakis, 1993). The presence of phthalic acid in all Indonesian microalgae may be an indicator that these strains were either able to hydrolyze DiBP by using specific enzymes or oxidation of unsaturated fatty acids. Conversely, presence of this compound could indicate sample contamination by plastic 
components used in sample processing (e.g., pipet tips, tubes). Further study in this area will be an interesting topic to be explored in the future.

The present study showed that the proximate compositions of Indonesian microalgae were roughly comparable to $T$. lutea and that these isolates may have potential to be used as larval shrimp food. All essential fatty acids required by shrimp larvae, ARA, EPA and DHA, were present in Indonesian strains at 25 psu except for Kb1-3 which only ARA presented. Culturing Kb1-2 and Kb1-5 strains at 25 psu, therefore, may supply the necessary PUFA required for larval survival and growth at optimum cell density. Otherwise, the use of these Indonesian strains can be in conjunction with other species, such as T. lutea, that contain higher levels of essential PUFA especially EPA. Further study on the effect of other environmental factors, such as light intensity, temperature, and culture medium may reveal the best culture condition for Indonesian strains to yield optimal PUFA. 


\section{References}

Ben-Amotz A, Tornabene TG, Thomas WH . 1985. Chemical profile of selected species of microalgae with emphasis on lipids. J Phycol 21:72-81

Brown, M.R., S.W Jeffrey, J.K. Volkman and G.A. Dunstan. 1997. Nutritional properties of microalgae for mariculture. Aquaculture 151:315-331.

Brown M.R. 2002. Nutritional value of microalgae for aquculture. In Cruz-Suárez LE, Ricque-Marie D, Tapia-Salazar M, Gaxiola-Cortés, MG. \& Simoes, N. (eds.). Avances en Nutrición Acuícola VI. Memorias del VI Simposium Internacional de Nutrición Acuícola. 3 al 6 de Septiembre del 2002. Cancún, Quintana Roo, México

Cai T, Park SY, Li Y. 2013. Nutrient recovery from wastewater streams by microalgae: Status and prospects. Renewable and Sustainable Energy Rev 19, 360-369

Cao Y, Wen G, Li, Z., Liu, X., Hu, X., Zhang, J., He, J. 2014. Effects of dominant microalgae species and bacterial quantity on shrimp production in the final culture season. J. Appl Phycol. 26:1749-1757

Castell, J.D. 1982. Fatty acid metabolism in crustceans. In: Biochemical and Physiological Approaches to Shellfish Nutrition. Proceedings of the 2nd International Conference on Aquaculture Nutrition October 27-29 at Lewes/Rehoboth Beach, Delaware (eds. G.D. Pruder, C. Langdon and D. Conklin), pp 124-145. Lousiana State University. Baton Rouge, Lousiana

Cheirsilp, B and S. Torpee. 2012. Enhanced growth and lipid production of microalgae under mixotrophic culture condition: Effect of light intensity, glucose concentration and fed-batch cultivation. Bioresource Technology 110:510-516.

Coutteau, P. 1996. Microalgae. In Lavens, P., Sorgeloos, P (eds). Manual in the production and use of live food for aquaculture. FAO Fisheries Technical Paper. No. 361. Rome, FAO. 1996. Pp 7-47.

Coutteau, P., M.R. Camara, P. Sorgeloos. 1996. The effect of different levels and sources of dietary phosphatidylcholine on the growth, survival, stress resistance, and fatty acid composition of postlarval Penaeus vannamei. Aquaculture. 147, 261-273

de Castro Araujo, S and V.N. Tavano Garcia. 2005. Growth and biochemical composition of the diatom Chaetoceros cf.wighamii brightwell under different temperature, salinity and carbon dioxide levels. I. Protein, carbohydrates and lipids. Aquaculture 246:405-412. 
Ding J, Wang C, Xie Z, Li J, Yang Y, Mu Y. 2015. Properties of a newly identified esterase from Bacillus sp. K91 and Its Novel Function in Diisobutyl Phthalate Degradation. PLoS ONE 10(3): e0119216.

D’Souza, F.M.L and N.R Loneragan. 1999. Effects of mono specific and mixed algal diets on survival, development and fatty acid composition of penaied prawn (Penaeus sp) larvae. Marine Biology 133:621-633.

Durvasula, R., Hurwitz, I., Fieck, A., Rao, DVS. 2015. Culture, growth, pigments and lipid content of Scenedesmus species, an extremophile microalga from Soda Dam, New Mexico in wastewater. Algal Research. 10, 128-133

Fidalgo, J.P., Cid, A., Torres, E. 1998. Effects of nitrogen source and growth phase on proximate bio- chemical composition, lipid classes and fatty acid profile of the marine microalga Isochrysis galbana. Aquaculture. 166, 105-116

Glencross, B. D. 2009. Exploring the nutritional demand for essential fatty acids by aquaculture species. Reviews in Aquaculture. 1, 71-124

Gonzalez-Araya, R., I. Que'au, C. Quere, J. Moal and R. Robert. 2011. A physiological and biochemical approach to selecting the ideal diet for Ostrea edulis (L.) broodstock conditioning (part A). Aquaculture Research 42:710-726.

Gorgônio, CMS, Aranda, DAG, Couri, S. 2013. Morphological and chemical aspects of Chlorella pyrenoidosa, Dunaliella tertiolecta, Isochrysis galbana and Tetraselmis gracilis microalgae. Natural Science. 7, 783-791

Hende SVD, Claessens L Muylder ED, Boon N, Vervaeren H. 2016. Microalgal bacterial flocs originating from aquaculture wastewater treatment as diet ingredient for Litopenaeus vannamei (Boone). Aquaculture Research 47, 1075-1089

Huang, X., Z. Huang, W. Wen and J. Yan. 2013. Effects of nitrogen supplementation of the culture medium on the growth, total lipid content and fatty acid profiles of three microalgae (Tetraselmis subcordiformis, Nannochloropsis oculata and Pavlova viridis). Journal of Applied Phycology 25:129-137.

Huerlimann, R., de Nys, R., Heimann, K. 2010. Growth, Lipid Content, Productivity, and Fatty Acid Composition of Tropical Microalgae for Scale-Up Production. Biotechnology and Bioengineering, 107, 247-257

$\mathrm{Hu} \mathrm{H}$, Gao K (2006) Response of growth and fatty acid compositions of Nannochloropsis sp. to environmental factors under elevated CO2 concentration. Biotechnol Lett 28:987-992 
Iba, Wa., Rice, M. A, Wikfors, G.H. 2014. Microalgae in Eastern Pacific White Shrimp, Litopenaeus vannamei (Boone 1931) hatcheries: A Review on Roles and Culture Environments. Asian Fisheries Science Journal. 27, 212-233

Jamali H, Ahmadifard N, Abdollahi, D (2015) Evaluation of growth, survival and body composition of larval white shrimp (Litopenaeus vannamei) fed the combination of three types of algae. International Aquatic Research 7:115-122

Kalita, N., Baruah, G., Goswami, R.C.D., Talukdar, J., Kalita, M.C., 2011. Ankistrodesmus falcatus: a promising candidate for lipid production, its biochemical analysis and strategies to enhance lipid productivity. J. Microbiol. Biotechnol. Res. 1

Kawamura, K., and R. B. Gagosian. 1987. Implications of $₫$-oxocarboxylic acids in the remote marine atmosphere for photo-oxidation of unsaturated fatty acids. Nature. 325, 330-332

Khatoon, H., S. Banerjee, F. Md Yusoff and M. Shariff. 2010. Effects of salinity on the growth and proximate composition of selected tropical marine periphytic diatoms and cyanobacteria. Aquaculture Research 41:1348-1355.

Khatoon, H., Rahman, N.A., Banerjee, S., Harun, N., Suleiman, S.S., Zakaria, N.H., Lananan, F., Hamid, S.H.A., Endut. A. 2014. Effects of different salinities and pH on the growth and proximate composition of Nannochloropsis sp. and Tetraselmis sp. isolated from South China Sea cultured under control and natural condition. International Biodeterioration \& Biodegradation. 95, 11e18

Lim, C.E. 1998. Feeding penaid shrimp. In T. Lowell (ed). Nutrition and Feeding in Fish, pp 228-271. Kluwer Academic Publishing. USA.

Mata, T. M., Martins, A.A., Caetano, N.S. 2010. Microalgae for biodiesel production and other applications: A review. Renewable and Sustainable Energy Reviews. $14,217-232$

Matsunaga T, Takeyama H, Nakao T, Yamazawa A (1999) Screening of marine microalgae for bioremediation of cadmium-polluted seawater. Journal of Biotechnology. 70, 33-38

Martínez-Fernández, E., Acosta-Salmón, H., Southgate, P.C. 2006. The nutritional value of seven species of tropical microalgae for black-lip pearl oyster (Pinctada margaritifera, L.) larvae. Aquaculture. 257, 491-503

Millamena, O.M. 1996. Review of SEAFDEC/AQD fish nutrition and feed development research. In: Feeds for Small-Scale Aquaculture. Proceedings of the National Seminar-Workshop on Fish Nutrition and Feeds (eds. C. B.Santiago, R.M. Coloso, O.M. Millamena and I.G. Borlongan), pp. 52-63. SEAFDEC Aquaculture Department,Iloilo. Philippines 
Miller, MM., Quek, SY., Staehler, K., Nalder, T., Packer, M.A. 2014. Changes in oil content, lipid class and fatty acid composition of the microalga Chaetoceros calcitrans over different phases of batch culture. Aquaculture Research. 45, 1634-1647

Mochida, M., A. Kawabata, K. Kawamura, H. Hatsushika, and K. Yamazaki, Seasonal variation and origins of dicarboxylic acids in the marine atmosphere over the western North Pacific, J. Geophys. Res., 108 (D6), 4193.

Moheimani, N.R., Borowitzka, M.A., Isdepsky, A., Sing, S.F. 2012. Standard Methods for Measuring Growth of Algae and Their Composition. In Algae for Biofuel and Energy. Borowitzka, M.A., Moheimani, N.R (eds). Springer. New York. Pp. 266284

Nalder, T.D., Miller, M.R., Packer, M.A. 2015. Changes in lipid class content and composition of Isochrysis sp. (T-Iso) grown in batch culture. Aquacult Int . 23:1293-1312

Nuñes, A.J.P., M.V.C Sa and H. Sabry-Neto. 2011. Growth performance of the white shrimp, Litopenaeus vannamei, fed on practical diets with increasing levels of the Antartic krill meal, Euphasia superba, reared in clear-versus green-water culture tanks. Aquaculture Nutrition 17:e511-e520.

Nuñez, M., C. Lodeiros, M. de Donato and C. Graziani. 2002. Evaluation of microalgae diets for Litopenaeus vannamei larvae using a simple protocol. Aquaculture International 10: 177-187.

Piña P, Voltolina D, Nieves M, Robles M (2006) Survival, development and growth of the Pacific white shrimp Litopenaeus vannamei protozoea larvae, fed with monoalgal and mixed diets. Aquaculture 253:523-530.

Ponomarenko, L.P., Stonik, I.V., Aizdaicher, N.A., Orlova, T.Yu., Popovskaya, G.I., Pomazkina, G.V., Stonik, V.A. 2004. Sterols of marine microalgae Pyramimonas Cf. cordata (Prasinophyta), Attheya ussurensis sp. nov. (Bacillariophyta) and a spring diatom bloom from Lake Baikal. Comparative Biochemistry and Physiology Part B. 138, 65-70

Renaud, S. M. Parry, D. L. 1994. Microalgae for use in tropical aquaculture II: Effect of salinity on growth, gross chemical composition and fatty acid composition of three species of marine microalgae. Journal of Applied Phycology 6: 347-356

Renaud, SM., Thinh, LV., Parry, D.L. 1999. The gross chemical composition and fatty acid composition of 18 species of tropical Australian microalgae for possible use in mariculture. Aquaculture. 170, 147-159 
Renaud, S.M., , L.V. Thinh, G. Lambrinidis and D.L. Parry. 2002. Effect of temperature on growth, chemical composition and fatty acid composition of tropical Australian microalgae grown in batch cultures. Aquaculture. 211:195-214

Ruangsomboon S, Ganmanee M, Choochote S. 2013. Effects of different nitrogen, phosphorus, and iron concentrations and salinity on lipid prcoduction in newly isolated strain of the tropical green microalga, Scenedesmus dimorphus KMITL. J Appl Phycol 25:867-874

Schwenk, D., Seppälä, J., Spilling, K., Virkki, A., Tamminen, T., Oksman-Caldentey, K.M., Rischer, H. 2013. Lipid content in 19 brackish and marine microalgae: influence of growth phase, salinity and temperature. Aquat Ecol. 47:415-424

Stephanou, E. G., and N. Stratigakis. 1993. Oxocarboxylic and a, w-dicarboxylic acids: Photooxidation products of biogenic unsaturated fatty acids present in urban aerosols, Environ. Sci. Technol., 27, 1403- 1407

Talebi A.H, Mohtashami, SK, Tabatabaei, M., Tohidfar, Bagheri, A., Zeinalabedini, M., Mirzaei, H.H., Mirzajanzadeh, M., Shafaroudi, S.M., Bakhtiari, S. 2013. Fatty acids profiling: A selective criterion for screening microalgae strains for biodiesel production. Algal Research. 2, 258-267

Teshima, S. 1982. Sterol metabolism. In: Biochemical and Physiological Approaches to Shellfish Nutrition. Proceedings of the 2nd International Conference on Aquaculture Nutrition October 27-29 at Lewes/Rehoboth Beach,Delaware (eds. G.D. Pruder, C. Langdon and D. Conklin), pp 205-216. Lousiana State University. Baton Rouge, Lousiana.

Tobias-Quinito E., Villegas, C. 1982. Growth, survival and macronutrient composition of Penaeus monodon larvae feed with Chaetoceros calcitrans and Tetraselmis chuii. Aquaculture 25: 253-260

Vonshak, A., Torzillo, G. 2004. Environmental Stress Physiology. In Richmond, A (ed). Handbook of Microalgal Culture: Biotechnology and Applied Phycology. . Blackwell Publishing Ltd. Iowa. USA. Pp 57-82

Xu X-Q, Beardall J. 1997. Effect of salinity on fatty acid composition of a green microalga from an Antarctic hypersaline lake. Phytochemistry 45:655-658

Zhila N, Kalacheva G, Volova T. 2011. Effect of salinity on the biochemical composition of the alga Botryococcus braunii Kütz IPPAS H-252. J Appl Phycol. $23: 47-52$ 


\section{TABLES}

Table 1. Fatty acids concentration as percent of total fatty acids found in Indonesian microalgae strains and T. lutea at different salinity

\begin{tabular}{|c|c|c|c|c|c|c|c|c|c|c|c|c|c|c|c|c|}
\hline \multirow{2}{*}{$\begin{array}{l}\text { Fatty } \\
\text { Acids }\end{array}$} & \multicolumn{4}{|c|}{ Kb1-2 } & \multicolumn{4}{|c|}{$\mathrm{Kb} 1-3$} & \multicolumn{4}{|c|}{ Kb1-5 } & \multicolumn{4}{|c|}{ T. lutea } \\
\hline & 20 & 25 & 30 & 35 & 20 & 25 & 30 & 35 & 20 & 25 & 30 & 35 & 20 & 25 & 30 & 35 \\
\hline $14: 0$ & 18.52 & 9.88 & 4.09 & 13.72 & & 2.07 & 8.47 & 1.66 & 29.28 & 4.41 & 23.13 & 6.63 & 3.45 & 0.41 & 1.05 & \\
\hline $15: 0$ & 0.15 & 1.08 & 0.16 & 1.47 & 0.61 & & 0.80 & 2.67 & 4.02 & 0.97 & 4.16 & 0.43 & 1.12 & 0.99 & 1.00 & \\
\hline $16: 0$ & 43.93 & 36.83 & 8.30 & 34.23 & 22.79 & 9.41 & 31.01 & 9.43 & 9.22 & 28.09 & 17.35 & 19.50 & 45.47 & 6.29 & 18.27 & 10.18 \\
\hline $17: 0$ & & 0.10 & & 0.28 & 22.07 & 32.23 & 6.51 & 2.39 & 0.59 & 0.18 & 0.17 & 0.24 & & & 0.36 & \\
\hline 18:0 & 14.67 & 12.16 & 12.22 & 10.42 & 11.01 & 4.02 & 17.20 & 5.48 & 4.26 & 12.26 & 7.43 & 8.88 & 15.27 & & 5.53 & 3.65 \\
\hline 20:0 & 0.27 & & & 0.73 & & & 0.20 & & 0.59 & & & 0.39 & 12.40 & 16.09 & 20.69 & 23.53 \\
\hline 21:0 & & & 14.58 & 4.73 & 11.90 & & 2.68 & 7.13 & & & 0.33 & 0.21 & 1.42 & & & 0.59 \\
\hline $22: 0$ & & & & & & & 0.75 & 4.25 & 0.18 & & 2.77 & 3.23 & 1.05 & & & \\
\hline $16: 1 \omega 7$ & 0.62 & & 0.35 & 3.62 & & & & 28.00 & 4.59 & 0.16 & 0.44 & & & & & \\
\hline $16: 1 \omega 9$ & & & & & & & & & & & & 0.12 & & 0.40 & & 0.70 \\
\hline $18: 1 \omega 9$ & 0.38 & 0.44 & 0.18 & 3.08 & 0.75 & & 0.35 & 1.45 & 2.25 & & 0.45 & & & 0.41 & 0.88 & 0.57 \\
\hline $20: 1 \omega 9$ & 0.88 & 2.09 & 0.39 & 0.45 & & 1.35 & 2.52 & 1.41 & & & & 3.11 & 3.66 & & 2.01 & 0.56 \\
\hline $18: 2 \omega 6$ & & & & 0.57 & & & & & 0.27 & & & & 2.89 & 28.58 & 21.96 & 26.72 \\
\hline $18: 3 \omega 3$ & & & & 1.12 & & & & & & & & & & & 0.44 & 0.49 \\
\hline $20: 2 \omega 6$ & 0.21 & 0.16 & & 0.09 & & & & 1.50 & & 1.75 & 0.27 & & & & & \\
\hline $20: 4 \omega 6$ & & 0.40 & & 1.26 & 7.90 & 2.50 & 3.09 & 2.42 & 1.64 & 4.65 & 0.95 & 0.39 & & & & \\
\hline $20: 5 \omega 3$ & & 1.23 & & 0.09 & & & & 1.10 & & 11.51 & & & 1.31 & 6.14 & 10.88 & 13.16 \\
\hline $22: 6 \omega 3$ & & 0.85 & 0.09 & 3.73 & & & & 3.50 & 1.48 & 2.20 & 1.46 & & & 1.85 & 4.79 & 4.27 \\
\hline Total Sufa & 77.83 & 60.84 & 39.45 & 67.11 & 78.86 & 84.60 & 68.58 & 59.16 & 72.74 & 46.96 & 60.94 & 44.83 & 92.14 & 62.62 & 59.04 & 53.53 \\
\hline Tota Mufa & 1.88 & 2.53 & 0.93 & 7.15 & 0.75 & 1.35 & 2.87 & 30.87 & 6.84 & 0.16 & 0.89 & 3.23 & 3.66 & 0.81 & 2.90 & 1.83 \\
\hline Total Pufa & 0.21 & 2.64 & 0.09 & 6.85 & 7.90 & 2.50 & 3.09 & 8.51 & 3.39 & 20.11 & 2.68 & 0.39 & 4.20 & 36.57 & 38.06 & 44.64 \\
\hline
\end{tabular}

$\mathrm{Sufa}=$ saturated fatty acids, Mufa= monounsaturated fatty acids, $\mathrm{Pufa}=$ polyunsaturated fatty acids 
Table 2. Cell weight in pg.cell ${ }^{-1}$, division rate $(\mathrm{k})$ and final biomass in $10^{6}$ cells $\mathrm{mL}^{-1}$ of Indonesian microalgal strains and T. lutea. Values are mean \pm SE from 4 replicates for $\mathrm{k}$ and 8 replicates for final biomass.

\begin{tabular}{llllll}
\hline $\begin{array}{l}\text { Strain/ } \\
\text { Variables }\end{array}$ & $\begin{array}{l}\text { Kb1-2 } \\
\text { (Chaetoceros sp. })\end{array}$ & Kb1-3 & Kb1-5 & Ti.lutea & p-value \\
& & & & & \\
\hline Cell weight & 22.1 & 20.7 & 15.6 & 21.8 & $<.0001$ \\
Biomass & $1.6 \pm 1.3^{\mathrm{c}}$ & $4.6 \pm 2.6^{\mathrm{a}}$ & $2.5 \pm 2.1^{\mathrm{b}}$ & $1.4 \pm 0.7^{\mathrm{c}}$ & $<.0001$ \\
$\mathrm{k}$ & $0.9 \pm 0.04^{\mathrm{dc}}$ & $1.0 \pm 0.07^{\mathrm{bcd}}$ & $1.4 \pm 0.04^{\mathrm{a}}$ & $0.8 \pm 0.03^{\mathrm{d}}$ & $<.0001$ \\
\hline
\end{tabular}




\section{FIGURE LEGENDS}

Figure 1. Proximate composition (\% dry weight) of Indonesian microalgae (a=Chateroceros sp., $\mathrm{b}=\mathrm{Kb} 1-3, \mathrm{c}=\mathrm{Kb} 1-5)$ and $T$. lutea $(\mathrm{d})$ cultured at 20, 25, 30 and 35 psu. Bars indicate standard error $(n=2)$. Bars with common letter for a particular component within a panel are not significantly different

Figure 2. Fatty acids distribution in Indonesian microlalgal strains in percent of total fatty acids $(\mathrm{a}=\mathrm{Kb} 1-2, \mathrm{~b}=\mathrm{Kb} 1-3, \mathrm{c}=\mathrm{Kb} 1-5)$ and $T$. lutea $(\mathrm{d})$ at different salinity $(20,25$, 30 and $35 \mathrm{psu})$. Note that the y axes are not all on the same scale 


\section{Figure 1}

u

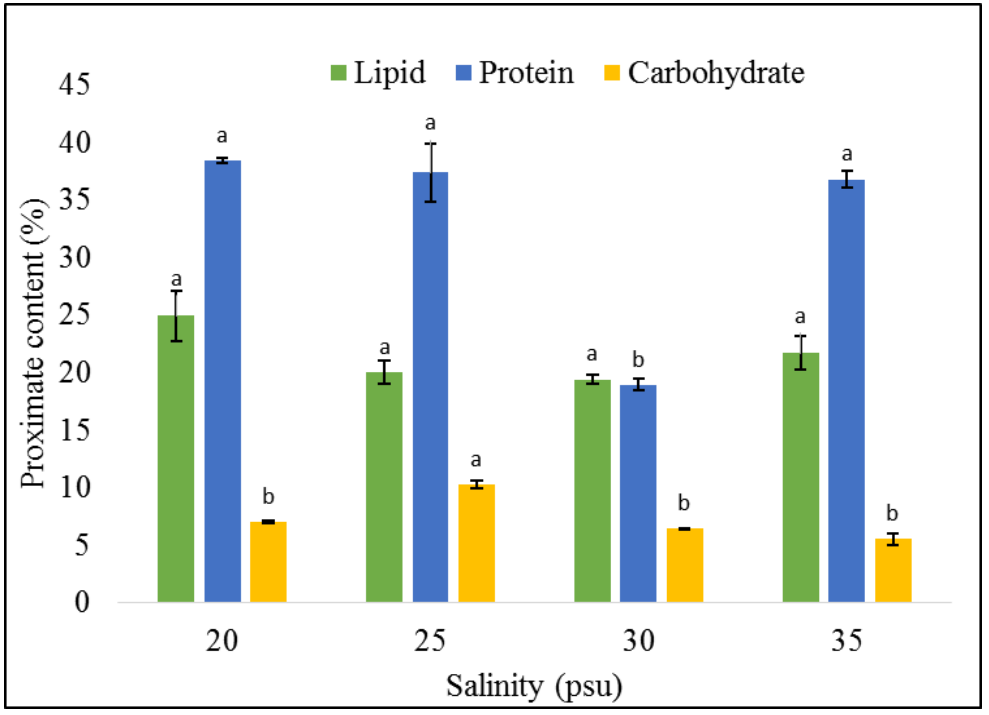

a

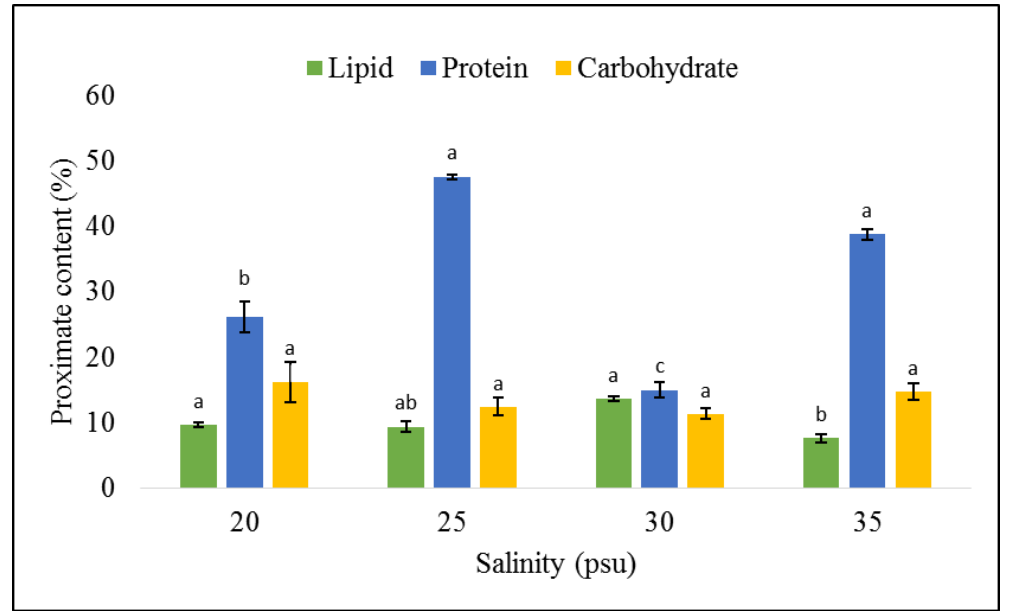

c

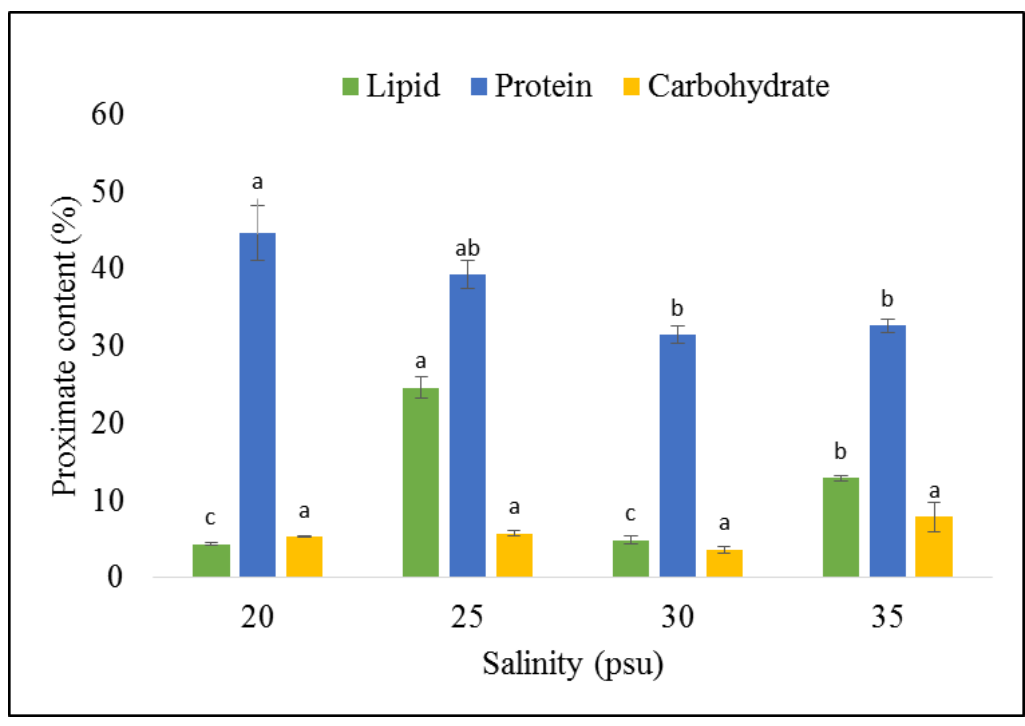

b

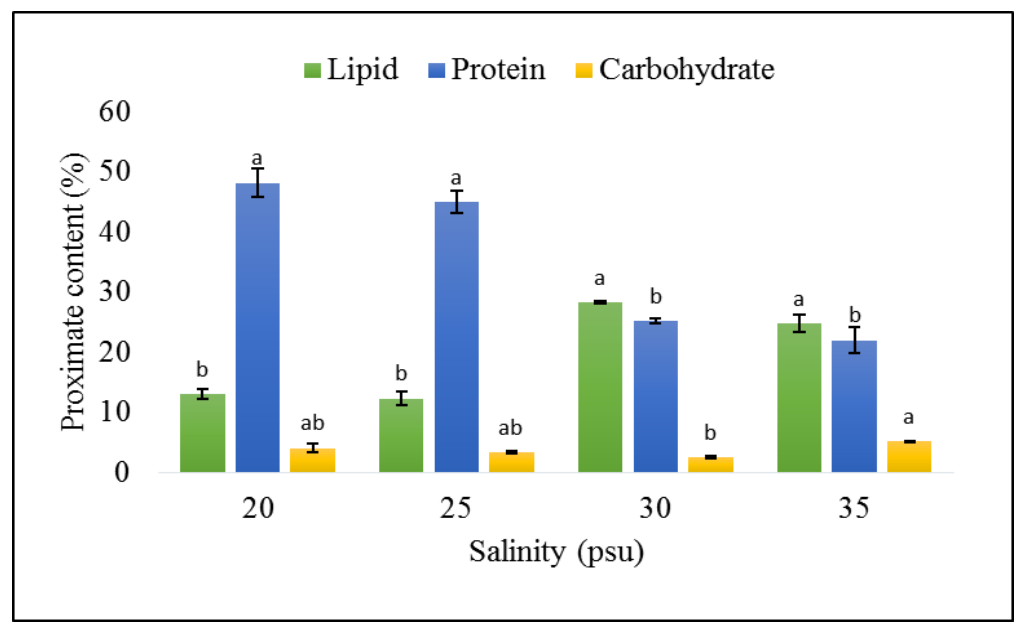




\section{Figure 2.}

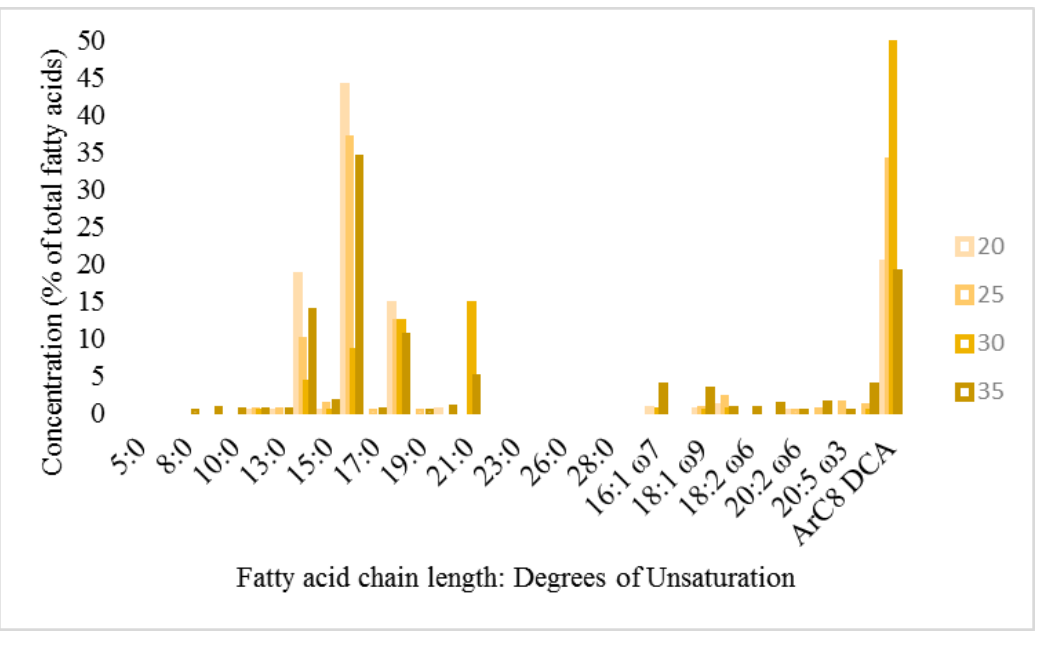

a

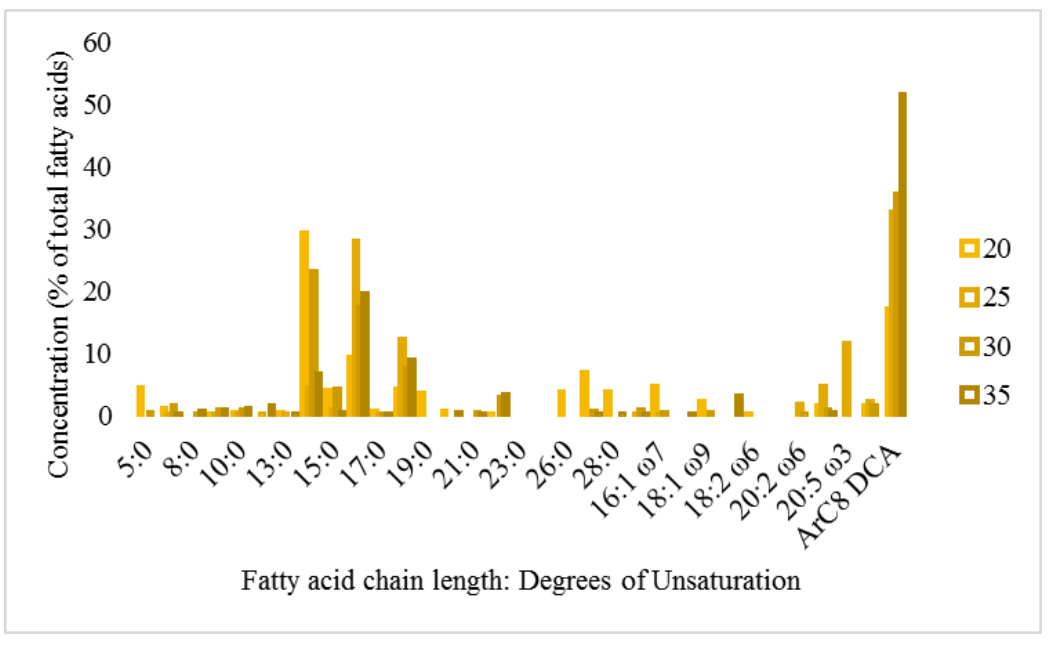

c

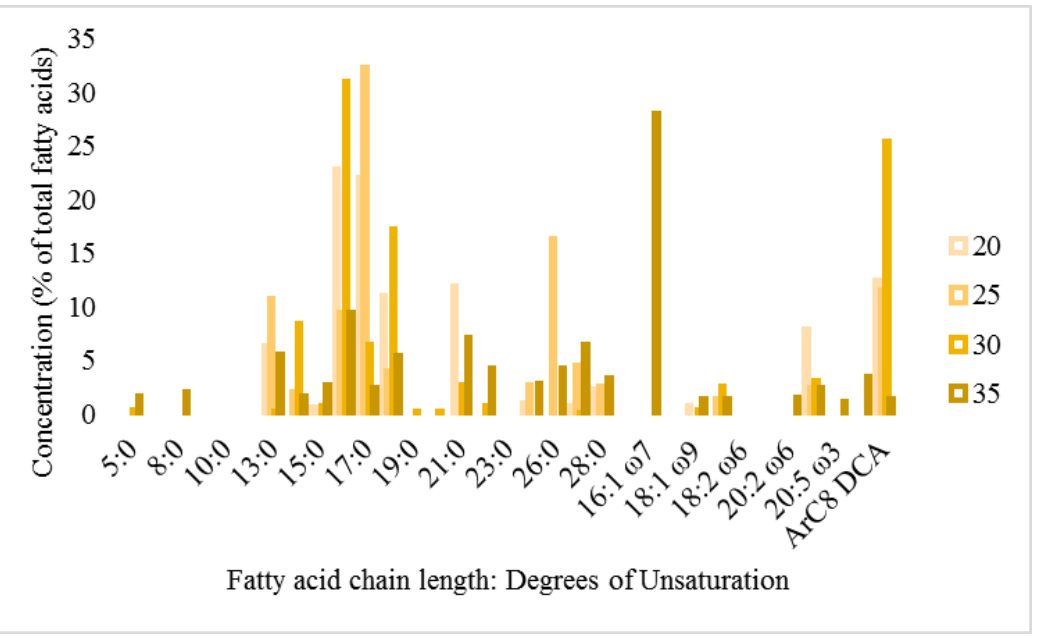

b

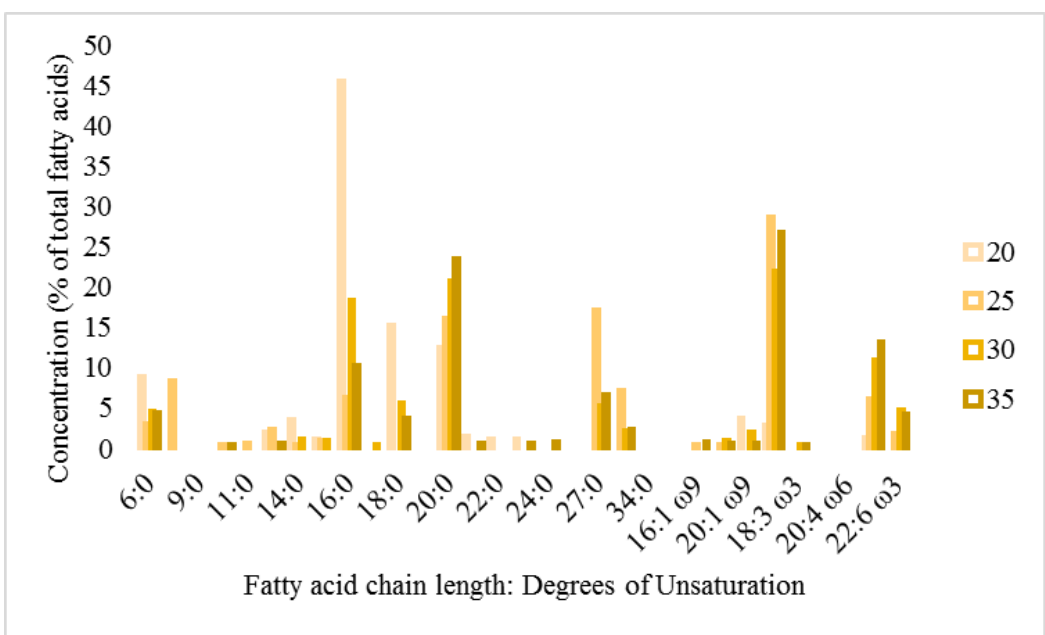




\title{
CHAPTER 4
}

Survival and growth of white shrimp (Litopenaeus vannamei) larvae fed newly isolated Indonesian strains of microalgae

\section{By}

\author{
Wa Iba ${ }^{1,2}$, Michael A. Rice ${ }^{1}$ Gary H. Wikfors ${ }^{3}$ \\ ${ }^{1}$ Department of Fisheries, Animal and Veterinary Sciences, University of Rhode Island, Kingston, RI \\ 02881 USA \\ ${ }^{2}$ Faculty of Fisheries and Marine Science, University of Halu Oleo. Kampus Hijau Bumi Tridharma \\ Anduonohu Kendari, SE Sulawesi, 93232. Indonesia \\ ${ }^{3}$ Northeast Fisheries Science Center, NOAA Fisheries Service 212 Rogers Avenue Milford, CT 06460 \\ USA
}




\section{Abstract}

Feeding experiments were conducted to investigate the ability of Indonesian strains of microalgae to support survival and growth of white shrimp (L. vannamei) larvae. Three Indonesian isolates (Kb1-2 identified as Chaetoceros sp., Kb1-3 and Kb1-5) and three standard aquaculture microalgal strains (Chaetoceros neogracile, Tisochrysis lutea and Tetraselmis chuii) were tested. Microalgae were cultured under natural, tropical conditions. Hatchery-reared shrimp larvae at the first protozoea stage $\left(\mathrm{PZ}_{\mathrm{I}}\right)$ were distributed into 1-L Erlenmeyer flasks containing $250 \mathrm{~mL}$ of $0.2-\mu \mathrm{m}$-filtered seawater in triplicate flasks and were fed single-species microalgal diets. After 8 days, more than $80 \%$ of the shrimp larvae had metamorphosed to the mysis stage in all microalgal diets, except for Kb1-2 (Chaetoceros sp.) and the non-fed control which the larvae had all died on day 3 or 4 when most of them were still in protozoeal stages. Survival of larval shrimp fed on Indonesian strains was similar to survival on C. neogracile and Te. chui. Survival on T. lutea was highest among strains tested at the end of experiment. Higher final dry weight and weight gain were observed in larvae fed on Kb1-5, Kb1-3 and $C$. neogracile compared to the rest of the strains with similar ingestion rate and food conversion index (FCI) to T. lutea. Larvae fed on Te.chui consistently had lower growth rate, final dry weight and weight gain. Indonesian microalgae may be suitable as food for white shrimp larvae, supporting performance similar to that of well-established strains; however, further studies with mixed algal diets may reveal greater performance than with any single strain alone.

Key words: white shrimp larvae, hatchery, microalgae, Indonesia 


\section{Introduction}

Continuous and sustainable availability of microalgae is one critical factor in aquaculture hatcheries to ensure the production of robust and healthy larvae, including white shrimp. The demand for white shrimp larvae is increasing as the number of shrimp farms has grown, particularly in some countries such as India, Indonesia, and Ecuador (Nikolik and Heinhuis, 2015). These new farms are operated mainly to supply the high demand of shrimp products in local or international seafood markets. At the end of 2014, the US market alone imported 560,773 tons of shrimp, an increase of 12.6\% from 2013 (Brown et al., 2015). Other large importers, such as Europe and Japan, are showing similar trends (Nikolik and Heinhuis, 2015), so there is an opportunity for shrimp hatcheries to produce shrimp larvae to support this increasing market demand.

Currently, hatchery practices worldwide still rely upon live microalgae cultured on site to feed early larval stages of white shrimp, despite some efforts to replace live microalgae with microencapsulated diets (Gallardo et al., 2002; Sanchez et al., 2012; Ma and Qin, 2012). Microalgae cultivated in shrimp hatcheries must maintain survival and growth, support metamorphosis, and provide natural color, as well as natural antibiotic activity for shrimp larvae to minimize the presence of pathogeens that may affect the survival of larval shrimp (Iba et al., 2014). Sources of microalgal strains in shrimp hatcheries usually are well-established microalgal culture centers such as The

Commonwealth Scientific and Industrial Research Organization (CSIRO) (http://www.csiro.au) in Australia (Martinez-Fernandez, 2007), Milford Laboratory (http://www.nefsc.noaa.gov/nefsc/Milford/) in United States of America (USA) 
(Wikfors and Ohno, 2001), The Culture Collection for Algae and Protozoa (CCAP) (http://www.ccap.ac.uk) in Scotland, the Research Center for Oceanography, in Indonesia, UTEX Culture Collection of Algae (https://www.utex.org) in Texas, USA and National Center for Marine Algae and Microbiota (https://ncma.bigelow.org/), in Maine, USA. Alternatively, microalgae can be isolated from local, natural ecosystems. Established microalgal species from the culture centers have several advantages, such as known nutritional profiles and ease of culture. Known species of microalgae used in shellfish-hatchery aquaculture, including shrimp hatcheries, are Isochrysis (Tisochrysis) spp. Thalassiosira weissflogii, Spirulina platensis, Tetraselmis spp. and many Chaetoceros strains including C. neogracile and C. calcitrans (Hemaiswarya et al., 2011; Treece and Fox, 1993).

In some parts of the world, however, where shrimp hatcheries and farming exist, the supply of microalgal strains can be a problem. For example, in Southeast Sulawesi, Indonesia, hatcheries of white shrimp usually import microalgae from other regions of Indonesia. This practice poses several risks that include high cost, difficult availability, low productivity, and possible parasite contamination from handling and shipping. Importing microalgae from other regions also increases greenhouse gas (GHG) emissions during transportation (Edwards-Jones, 2010). To reduce both the cost and GHG emissions, the use of locally-isolated, cultured microalgae for local hatcheries may be considered. Locally-isolated microalgae with good growth and complete nutritional profiles will help small-scale hatcheries and farmers to increase the productivity of their hatcheries and farms and thus their incomes. Once the productivity increases, the farms will supply more shrimp to the markets that may decrease the 
shrimp price and make them more affordable for local people. Finally, small-scale and local installations of microalgal culture will provide employment that can drive the economic growth of SE-Sulawesi and Indonesia in general. Therefore, in this study we investigated the possibility of using local isolates of microalgae from SE-Sulawesi in shrimp hatcheries by conducting a feeding study with white shrimp larvae fed newly isolated local microalgal strains.

\section{Materials and Methods}

\section{Algal Culture}

Three microalgal strains were isolated from Kendari Bay $\left(3^{\circ} 58^{\prime} 56^{\prime \prime} \mathrm{S}, 122^{\circ} 35^{\prime}\right.$ 53.1" E) and Wanggu River Estuary (358'46.3"S, $122^{\circ} 31^{\prime} 54.4^{\prime \prime}$ E) South East Sulawesi, Indonesia. The microalgal strains are denoted as Kb1-2, Kb1-3 and Kb1-5. The strains have been maintained for more than one year in the laboratory at the University of Rhode Island, USA. The commonly used species Tetraselmis chui, Tisochrysis lutea and Chaetoceros neogracile were used for control comparison. The description of microalgal strains used in this feeding experiment is in Chapter 2. All microalgae were cultured semi-continuously in 1,000-mL Erlenmeyer flasks containing $600 \mathrm{~mL}$ artificial seawater $\mathrm{f} / 2$ medium at $29-30^{\circ} \mathrm{C}$, at 30 and 35 psu salinity, with $30 \%$ daily harvests and replacement of the volume harvested with new medium. Higher salinity was chosen because previous growth trials with these strains showed better growth and yield at 30 and 35 psu (Chpater 2). Lighting was with natural, indirect sunlight in the range of $100-150 \mu \mathrm{mol}$ photons $\mathrm{m}^{-2} \mathrm{~s}^{-1}$ PAR under natural photoperiod (approximately 12:12, light:dark cycle). Microalgal cultures were maintained at the 
Laboratory of Fisheries University of Halu Oleo, Kendari, South East Sulawesi, Indonesia $\left(4^{\circ} 00^{\prime} 28.10^{\prime \prime} \mathrm{S}, 122^{\circ} 31^{\prime} 15.06^{\prime \prime} \mathrm{E}\right)$.

\section{Experimental Animals}

A complete, randomized experimental design was applied in this research. The experimental design was based upon Nuñez et al (2002) and Piña et al (2006). All trial animals were hatchery-produced from the Situbondo Shrimp Development Center (SSDC), East Java, Indonesia. Larvae of L. vannamei were obtained during the naupliar stage ( $\mathrm{N}_{\mathrm{IV}}$ and $\mathrm{N}_{\mathrm{V}}$ ) and upon arrival were maintained at $29-30^{\circ} \mathrm{C}$, salinity $30 \mathrm{psu}$, in $0.2-\mu \mathrm{m}$-filtered seawater in $10-\mathrm{L}$ containers with abundant aeration at the Laboratory of Fisheries University of Halu Oleo, Kendari, South East Sulawesi, Indonesia. Ti. lutea was supplied twice a day to shrimp at a cell count of $1 \times 10^{5} \mathrm{~mL}^{-1}$ until the shrimp larvae reached the end of the naupliar stage $\left(\mathrm{N}_{\mathrm{V}}\right)$ and underwent metamorphosis to protozoea I ( $\mathrm{PZ}_{\mathrm{I}}$ ) stage (protocol based upon the Standard Operational Procedure/SOP at SSDC).

The experimental treatments were started when $50 \%$ of the larvae had reached PZI stage. Initial larval dry weights were measured by concentrating 3 replicates of approximately 25 larvae on tared GF/F microfiber filters, following the method used to obtain microalgal dry weight (Moheimani et al. 2012). On the same day, approximately 500 larvae were concentrated in $100 \mathrm{~mL}$ of seawater and distributed evenly into 20 sterile, 1,000-mL Erlenmeyer flasks containing $250 \mathrm{~mL}$ of sterilized seawater with gentle aeration, so that the larval density was at least 1 larva. $10 \mathrm{~mL}^{-1}$ (SSDC, 2015). Three replicates were employed for each microalgal strain tested. Two flasks were used as unfed controls without microalgae, and two flasks were used as microalgae-only 
controls without shrimp. Temperature in all flasks was maintained by using continuous lighting with fluorescent lamps.

Larvae were fed twice daily at 7 am and 9 pm with increasing concentrations of algae at $1,1.5$, and $2 \times 10^{5}$ cells $\mathrm{mL}^{-1}$ for $\mathrm{PZ}$, $\mathrm{PZ}_{\mathrm{II}}$ and $\mathrm{PZ}$ III stages, respectively. At feeding time, $4 \mathrm{~mL}$ of each algal strain at the appropriate density were centrifuged to remove culture medium and diluted with $4 \mathrm{~mL} 0.22-\mu \mathrm{m}$-filtered seawater before being given to the shrimp. Food ingestion was calculated based upon counts of microalgal cells in larval culture water $24 \mathrm{~h}$ after feeding. Specifically, $3 \mathrm{~mL}$ of water was sampled daily from each culture, and the number of cells was counted in duplicate by light microscopy using a Sedgwick-Rafter chamber. On this time, number of live shrimp larva was counted and, when possible, photographic images were taken. Observation of developmental stage of the shrimp was conducted every $24 \mathrm{~h}$ by examination of the larvae in culture flasks using a magnifying glass. Daily ration of feed was adjusted after $50 \%$ of larvae had reached the next developmental stage in at least three flasks of the feeding treatment. The experiment was terminated after more than $80 \%$ of the larvae had reached the first mysis stage $\left(\mathrm{M}_{\mathrm{I}}\right)$ in one or more of the treatments. Final dry weight of shrimp was obtained from every replicate of each treatment after counting the larvae for final survival and subsequently filtering all of the surviving shrimps onto tared filter paper, dried at $100{ }^{\circ} \mathrm{C}$ for $1 \mathrm{~h}$ and weighing on an analytical balance.

Dry weight per cell of microalgae tested in this study was obtained from five replicate aliquots from microalgae-only control flasks during late logarithmic phase (8 days of culture) using methods described by Coutteau (1999). Microalgal density in $50 \mathrm{~mL}$ was determined using haemocytometer counts and weighing a known number of 
cells on tared GF/F glass-fiber (diameter $47 \mu \mathrm{m}$ ) filters after washing with $0.65 \mathrm{M}$ ammonium formate to remove salts. In addition, the same procedure was applied to triplicate control filters on which $50 \mathrm{~mL}$ of $0.22-\mu \mathrm{m}$ filtered seawater was filtered. The filters were dried at $60{ }^{\circ} \mathrm{C}$ for $24 \mathrm{~h}$ to volatilize the ammonium formate and weighed on an analytical balance. The dry weight per algal cell was calculated using the following equation:

$$
\text { DW }\left(\text { g. cell }{ }^{-1}\right)=\left(\mathrm{DW}_{A}-\mathrm{DW}_{\mathrm{C}}\right) \cdot(\mathrm{N} \cdot \mathrm{V})^{-1} \text {, when: }
$$

$\mathrm{DW}_{\mathrm{A}}=$ average dry weight retained on algal filter $(\mathrm{g}), \mathrm{DW} \mathrm{C}_{\mathrm{C}}=$ average dry weight retained on control filter $(\mathrm{g}), \mathrm{N}=$ algal density $\left(\right.$ cells. $\left.\mathrm{mL}^{-1}\right), \mathrm{V}=$ volume of algal culture and filtered seawater filtered on algal and control filter, respectively $(\mathrm{mL})$

Shrimp growth was calculated using two methods: (1) as the percentage of increasing dry weight and (2) as specific growth rate (SGR) for eight days as follows:

$$
\mathrm{SGR}=\ln \left(W_{t-} W_{0}\right) \cdot t^{-1}, \text { where: }
$$

$\mathrm{W}_{\mathrm{t}}=$ Shrimp dry weight at $\mathrm{t}$ day ( 8 days $), \mathrm{W}_{\mathrm{o}}=$ Initial dry weight of shrimp, $\mathrm{t}=$ days of experiment

The food conversion index (FCI) and gross growth efficiency $\left(k_{l}\right)$ of shrimp larvae for each microalgae tested were calculated using equations from Piña et al (2006), based upon the respective mean values of dry weight of the individual food items, the mean values of ingestion, and the mean dry weight gain of the larvae, as follows:

$$
\mathrm{FCI}=\mathrm{FS} . \mathrm{WG}^{-1} \text { and } k_{1}=100 . \mathrm{WG} \cdot \mathrm{FI}^{-1}
$$

where FS $=$ food supplied $(\mu \mathrm{g}), \mathrm{FI}=$ food ingested $(\mu \mathrm{g})$ and $\mathrm{WG}=$ weight gain $(\mu \mathrm{g})$ of dry weight.larva ${ }^{-1}$ 


\section{Statistical Analysis}

The effects of different microalgae strains on shrimp growth, FCI and $k_{l}$ were analyzed using one-way analysis of variance (ANOVA). Differences in shrimp survival were analyzed using mixed effect of repeated measure ANOVA. To meet ANOVA assumptions, percentage data were transformed using square root transformation. Significant differences in the data $(\mathrm{p}<0.05)$ were analyzed with pair-wise multiple comparison of means (Tukey test). All statistical analyses were done in SAS Enterprise Guide 7.1

\section{Results}

Larvae of white shrimp survived and metamorphosed to the mysis stage on day 8 in all microalgae tested except for the Kb1-2 strain and the non-fed control (Figure 1). Microscope observation confirmed that Kb1-2 cultures were contaminated by $T$. chui and bacteria after four days of culture. On day 2 of the experiment, larvae fed the Kb12 were all dead in one replicate; all larvae in remaining replicates died on day 4 of the experiment when they were in PZ II. Similarly, larvae in the non-fed control started to die on day 2 and subsequently were all dead on day 3 when still in PZI stage. Therefore, at those days, the larvae were filtered, dried and weighed to obtain the larval dry weight

for these treatments. These two treatments were excluded from subsequent ANOVA analysis for survival and growth. Similar final survival was observed in white shrimp larvae fed on Indonesian microalgae strain (except Kb1-2) to C. neogracile and Te. chui that ranging from 7-20\%. T. lutea produced the highest larval survival among microalgae tested at $31 \%$ (Fig. 1, Table 2). 
Higher final dry weight was found in larvae fed on Indonesian strains Kb1-3 and Kb1-5 (45.1 and $70.8 \mu \mathrm{g}$. larvae $^{-1}$, respectively) that was similar to C. neogracile at 50.6 $\mu$ g.larvae ${ }^{-1}$. Shrimp larvae fed on Kb1-3 showed a similar final dry weight to T. lutea and Te. chui (21.7 and $28.4 \mu$ g.larvae $^{-1}$, respectively (Table 1). Weight gain and percentage of increase of weight of white shrimp larvae were significantly affected by microalgae that they had been fed. Shrimp larvae fed on one Indonesian strain, Kb1-5, had a similar percentage of total increase in weight and weight gain (108\% and 64 $\mu \mathrm{g}$. larvae $^{-1}$, respectively) to those fed on C. neogracile (69 \% and $43 \mu \mathrm{g}$. larvae $^{-1}$, respectively) but higher compared to T. lutea (39\% and $21 \mu \mathrm{g}$. larvae $^{-1}$ ) and Te. Chui (37 \% and $21 \mu \mathrm{g}$. larvae $^{-1}$ ). Another Indonesian strain, Kb1-3, had a similar percentage of total increase in weight and weight gain to those fed on there other extensively use strains in aquaculture, C. neogracile, T. lutea and Te. Chui. Consequently, they had higher gross growth efficiency, growth rates and lower FCI $(\mathrm{p}<.0001, \mathrm{p}<.0001$ and $\mathrm{p}=0.012$, respectively, Tables 1,2 and 3).

Although shrimp larvae fed on Kb1-5 had a similar percentage of ingested food to $T e$. chui at 51 and $62 \%$, respectively, those larvae fed on Te. chui consistently had he highest FCI (53) and the lowest $k_{1}(16)$ among larvae fed on other microalgae tested. Larval shrimp fed on Te. chui and T. lutea had a similar growth rate at 0.16 and 0.15 $\mu$ g.larvae ${ }^{-1}$.day $^{-1}$, respectively, being the lowest among larvae fed on other strains tested. Feeding on Te. chui, however, resulted in similar final dry weight and weight gain to those fed on T. lutea and Kb1-3 (Table 1 and 3). 


\section{Discussion}

The performance of Indonesian microalgae in this study was similar to those of species that are used extensively for aquaculture hatcheries, except for the Kb1-2 strain. Bacterial and cross contamination may have interfered with feeding results with this strain, as massive bacterial contamination was observed under the microscope. The presence of bacteria in diatom feed cultures is common, and the relationship can be parasitic or symbiotic (Schaefer, 2001; Grossart et al, 2005). Mortality of larvae before reaching the end of the protozoea stage when fed the Kb1-2 strain suggested that bacteria present in the culture may have been harmful to the larvae, although several studies have found that diatom and bacterial interactions may support water quality beneficial for growth of shrimp in biofloc systems (Emerenciano et al, 2012; Hargreaves, 2013; Sakkaravarthi, 2015).

Survival of white shrimp larvae fed on Indonesian microalgal strains in this study was not significantly different $C$. neogracile and Te.chui. Survival of larvae was high $(>90 \%)$ during early stages of protozoea and decreased as the larvae metamorphosed into later stages. This phenomenon is common in the shrimp larval life cycle (Rodriguez et al., 2012, Kiametha et al., 2011, Okauchi and Okuda, 2003). Metamorphosis is considered a critical time for larvae and therefore the feeding rate needs to be adjusted to meet larval nutrition requirements to support larval growth and survival. Also, maintaining water quality at optimal level during larval culture will aid the metamorphosis process and thus increase the chance of larval survival (Trece and Fox, 1993). Larvae fed Indonesian microalgal strains showed final survival ranging from $7-11 \%$, statistically similar to survival on extensively-used microalgal species 
(13-20\%) except for T. lutea. This larvae survival on Indonesian strains of microalgae can be considered relatively low compared to survival reported in the study by Piña et al. (2006) which was 50\% on single algal species of Tahitian Isochrysis or TISO (which is T. lutea per Bendif, 2013), Tetraselmis suecica, or Chaetoceros muelleri. However, our result with a $32 \%$ survival of larvae fed on T. lutea was comparable. Nuñez et al (2002) studied the protozoeal stage of white shrimp with higher larval density and without water exchange, and reported PZ $\mathrm{III}$ survival between 66-76\%. By contrast, survival in"normal" hatchery operation has been reported to be 70-90\% with 100-150 shrimp..$^{-1}$ with water exchange (SSDC, 2015; Trece and Fox, 1993). Jamali et al (2015) showed that survival of $\mathrm{PZ}$ III stage of white shrimp larvae fed a single diet of microalgae I. galbana, Tetraselmis tetrahele, or C. muelleri was $72-79 \%$; whereas, the present study showed lower survival at that stage (4-60\%).

Overall survival in the present study was comparable to results reported by Kiametha et al (2011), which was less than $30 \%$ when white shrimp larvae were fed $C$. gracilis. High variation in survival can be attributed to several factors, including sufficient quantity of microalgae supplied, water quality, suitable cell size, disease and appropriate nutrition in the algae to support growth and development of white shrimp larvae (Brown et al., 1997; Okauchi and Tokuda; 2003; Piña et al., 2006; Jamali et al., 2015). In this study we observed that water in most of shrimp larvae culture flasks was constantly in green and brown color suggesting that food availability might not be a limiting factor to survival. Low survival may be a result of interaction between poor digestion and bacterial infection due to non-water exchange system during the experiment although further clinical study is needed to confirm this. We observed that 
larvae were able to ingest the microalgae supplied but they seemed to be unable to digest and thus convert these algae into metabolites substances that can be absorbed to support their survival.

Indonesian microalgal strains tested in this study were ingested at similar rates to those of well-known strains by white shrimp larvae. Larvae fed Indonesian strains, however, exhibited higher weight gains comparable to larvae fed C. neogracile, suggesting that the larvae were able to utilize the food for growth but not enough for survival. Although T. lutea is considered a good single-algal species to be used in shrimp hatcheries and is readily ingested by white shrimp juveniles due to its good nutritional profile and appropriate cell size (Iba et al., 2014; Hemaiswarya et al., 2011), this study showed that this species is inferior in terms of enhancing growth compared to C. neogracile and Indonesian strains $\mathrm{Kb} 1-3$ and Kb1-5. This finding confirmed the study by Pina et al (2006) who found that white shrimp larvae fed on Isochrysis sp. alone resulted in lower final weight of $27.11 \mu \mathrm{g} \cdot \mathrm{larvae}^{-1}$ compared to those fed on single diet of $C$. muelleri at $48.28 \mu$ g.larvae ${ }^{-1}$. Therefore, considering no water exchange during larval culture, it is suggested that growth and survival of larvae in this study maybe correlated to the presence of bacteria in both algae and larvae culture. We observed during this experiment, the formation of aggregates at the bottom of the flask that may contained bacteria and remnant of microalgae. Hargreaves (2013) stated that aggregates (flocs) of algae, bacteria, protozoans, and other kinds of particulate organic matter such as feces and uneaten feed in green water microalgae system in shrimp culture may improve growth and survival of the species during grow out stages. However, the effect of bioflocs on larval stages during hatchery phase is not investigated 
yet. $\mathrm{Kb} 1-3, \mathrm{~Kb} 1-5$ and $C$. neogracile may have appropriate nutrition, cell size and possibly harbored a 'good' bacterial assemblages that supported the digestion of the cells, thus promoted the growth of shrimp larvae, but some such as Kb1-2, T. lutea and Te.chui may not have, resulting in poor growth of the larvae.

Dry weight gain of surviving larvae fed Indonesian strains showed comparable performance to weight gain on a well-known microalgal species, $C$. neogracile. Consequently, white shrimp larvae fed on Indonesian strains showed similar growth rates to those fed on $C$. neogracile which was not the case for T. lutea and Te. chui. This finding confirms similar studies by Nuñez et al (2002), who used a native microalgal strain (two strains of Chaetoceros sp.) from Venezuela and also supports numerous other studies that microalgae from the Class Bacillariophyceae are still preferred as food for shrimp larvae regardless of the source of the isolates (Nuñez et al, 2002; Okauchi and Okuda, 2003; Piña et al; 2006, Kiametha et al., 2011; Kent et al., 2011). Food conversion index of shrimp larvae was not significantly different among strains of microalgae tested, except for Te. chui which had the lowest FCI of other algal diets. This suggests that shrimp larvae may not be able to ingest the cells of Te. chui properly, resulting in lower weight gain per larva compared to other treatments. Other studies have shown that microalgae from the genus Tetraselmis may not be adequate for white shrimp larvae (Piña et al. 2006, Rodriguez et al. 2012, Jamali et al. 2015). Although Chaetoceros strains showed lower performance as feed of white shrimp compared to another diatom species, T. weissflogii, as reported by Kiametha et al. (2011), our study showed that Indonesian strains were comparable to C. neogracile as feed for white shrimp larvae and confirms previous studies finding that Chaetoceros 
strains, such as $C$. muelleri, are suitable to feed early stages of shrimp larvae (Piña et al, 2006, Rodriguez et al, 2012, Jamali et al, 2015). Studies by Kiametha et al. (2011) and Kent et al (2011) showed that $T$. weissflogii was readily ingested and digested by shrimp larvae, resulting in higher growth and survival compared to Chaetoceros strains. Nevertheless, our study showed that Indonesian microalgae strains, T. lutea, and $C$. neogracile were able to support growth of shrimp larvae up to mysis stage in the absence of T. weissflogii.

This study showed that local Indonesian microalgal strains have potential to be used for larval rearing of white shrimp, at least up to the mysis stage. However, further study of the effects of mixed diets of Indonesian microalgal strains with well-known microalgal species upon larval survival, growth, and metamorphosis is recommended. We recommend experiments at commercial scale with water exchange to mimic the common practice in commercial hatcheries. Although longer term and larger commercial scale experiments may be needed to employ these newly isolated strains into aquaculture, this study is useful as an initial step to support aquaculture industries as well as to support algal research and its wider applications. Finally, the roles of water quality and bacterial assemblages in microalgal culture to support shrimp larval growth and survival in culture practice without water exchange are also interesting to be explored in the future. 


\section{References}

Bendif EM., Probert I, Schroeder DC, and de Vargas C (2013) On the description of Tisochrysis lutea gen. nov. sp.nov. and Isochrysis nuda sp. nov. in the Isochrysidales, and the transfer of Dicrateria to the Prymnesiales (Haptophyta). Journal of Applied Phycology 25:1763-1776.

Brown, M.R., Jeffrey S.W. 1992. Biochemical composition of microalgae from the green algal classes Chlorophyceae and Prasinophyceae. 1. Amino acids, sugars and pigments. Journal of Experimental Marine Biolagy and Ecology. 161, 91113

Brown M.R, Jeffrey S.W, Volkman J.K, Dunstan G.A (1997). Nutritional properties of microalgae for mariculture. Aquaculture 151: 315-331

Brown P. Jr (2015) U.S. Shrimp Imports Approach Record Annual Volume. Global Aquaculture Advocate Magazine. March/April 2015:58-60.

Coutteau, P. 1996. Microalage. In Manual on the production and use of live food in aquaculture. FAO Technical paper no 361. Lavens, P., Sorgeloos, P (eds). FAO Rome, Italy. pp 7-48.

Edwards-Jones G (2010) Does eating local food reduce the environmental impact of food production and enhance consumer health? Symposium on 'Food supply and quality in a climate-changed world'. Proceedings of the Nutrition Society 69:582591.

Emerenciano M, Ballester ELC, Cavalli RO, Wasielesky, W (2012) Biofloc technology application as a food source in a limited water exchange nursery system for pink shrimp Farfantepenaeus brasiliensis (Latreille, 1817). Aquaculture Research 43:447-457

Gallardo PP, Pedroza-Islas R, Garcia-Galano T, Pascual T, Rosal C, Sanchez A, Gaxiola, G (2002) Replacement of live food with microbound diet in feeding Litopaneus setiferus (Burkenroad) larvae. Aquaculture Research 33:681-691.

Grossart HA, Levold F, Allgaler M, Simon M, Brinkhoff T (2005) Marine diatom species harbor distinct bacterial communities. Environmental Microbiology $7: 860-873$

Hargreaves JA (2013) Biofloc production systems for aquaculture. Southern Regional Aquaculture Center SRAC Publication 4503: April 2013

Hemaiswarya S, Raja R, Kumar RR, Ganesan V, Anbazhagan C (2011) Microalgae: a sustainable feed source for aquaculture. World Journal of Microbiology and Biotechnology 27:1737-1746. 
Iba W, Rice MA, Wikfors GH (2014) Microalgae in eastern pacific white shrimp, Litopenaeus vannamei (Boone 1931) hatcheries: a review on roles and culture environments. Asian Fisheries Science 27:212-233

Jamali H, Ahmadifard N, Abdollahi, D (2015) Evaluation of growth, survival and body composition of larval white shrimp (Litopenaeus vannamei) fed the combination of three types of algae. International Aquatic Research 7:115-122

Kent M, Browdy CL, Leffler J.W (2011) Consumption and digestion of suspended microbes by juvenile Pacific white shrimp Litopenaeus vannamei. Aquaculture 319:363-368.

Ma Z, Qin, JG (2012) Replacement of fresh algae with commercial formulas to enrich rotifers in larval rearing of yellowtail kingfish Seriola lalandi (Valenciennes, 1833). Aquaculture Research 45:949-960.

Moheimani NR, Borowitzka MA, Isdepsky A, Sing SF (2012) Standard methods for measuring growth of algae and their composition. In Borowitzka MA, Moheimani NR (eds) Algae for biofuel and energy. Springer, New York, pp 266-284

Nikolik G, Heinhuis L (2015) Rabobank world seafood trade map 2015. Rabobank industry note \#486:March 2015

Nuñez M, Lodeiros C, De Donato M, Graziani C (2002) Evaluation of microalgae diets for Litopenaeus vannamei larvae using a simple protocol. Aquaculture International 10:177-187.

Okauchi M, Tokuda M (2003) Trophic value of the unicellular diatom Phaeodactylum tricornutum for larvae of Kuruma prawn, Penaeus japonicus. Paper presented at the 32nd UJNR aquaculture panel meeting on aquaculture and pathobiology of crustacean and other species, Davis and Santa Barbara, CA, 16-22 November 2003

Piña P, Voltolina D, Nieves M, Robles M (2006) Survival, development and growth of the Pacific white shrimp Litopenaeus vannamei protozoea larvae, fed with monoalgal and mixed diets. Aquaculture 253:523-530.

Rodríguez EO, López-Elías JA, Aguirre-Hinojosa E, Garza-Aguirre MC, ConstantinoFranco F, Miranda-Baeza A, Nieves-Soto M (2012) Evaluation of the nutritional quality of Chaetoceros muelleri Schütt (Chaetocerotales: Chaetocerotaceae) and Isochrysis sp. (Isochrysidales: Isochrysidaceae) grown outdoors for the larval development of Litopenaeus vannamei (Boone, 1931) (Decapoda: Penaeidae ). Arch. Biol. Sci Belgrade 64 (3): 963-970. 
Sakkaravarthi K (2015) Determination of effective microbial community for biofloc shrimp culture system. International Journal of Fisheries and Aquatic Studies 3: 276-281

Sanchez DR, Fox JM, Gatlin III R, Lawrence AL (2012) Dietary effect of fish oil and soybean lecithin on growth and survival of juvenile Litopenaeus vannamei in the presence or absence of phytoplankton in an indoor system. Aquaculture Research 45:1367-1379.

Schaefer H (2001) Dynamic of the genetic diversity of marine bacterial assemblages. Dissertation, University of Bremen

Situbondo Shrimp Development Center (2015) Standard operational procedures for shrimp hatchery unit at Gelung, Situbondo. Aquaculture Directorate General. Ministry of Fisheries and Marine Affairs. Indonesia

Treece GD, Fox JM (1993) Design, Operation and Training Manual for an Intensive Culture Shrimp Hatchery. Texas A\&M University Sea Grant College Program

Villegas CT, Kanazawa A (1979) Relationship between diet composition and growth of zoeal and mysis stages of Penaeus japonicus (Bate). Fisheries Resources Journal of the Philippines 4:32-40.

Wikfors GH, Ohno M (2001). Impact of algal research in aquaculture. Journal of Phycology 37:968-974. 


\section{TABLES}

Table 1. Initial and final dry weight (DW) of larvae Litopenaeus vannamei in $\mu \mathrm{g}$.larvae ${ }^{-1}$ fed with Indonesian microalgae strains, $C$. neogracile, T. lutea and Te. chui during protozoea stages. Standard errors (SE) about the mean are for 3 replicates for all strains. Numbers with same superscript letters indicate lack of significant differences $(\mathrm{p}=0.05$, Tukey test)

\begin{tabular}{lll}
\hline Strain & Initial DW $\pm \mathrm{SE}$ & Final DW $\pm \mathrm{SE}$ \\
\hline $\mathrm{Kb} 1-3$ & $6.8 \pm 0.3$ & $45.1 . \pm 1^{\mathrm{ab}}$ \\
Kb1-5 & $6.8 \pm 0.3$ & $70.8 \pm 5^{\mathrm{a}}$ \\
C. neogracile & $6.8 \pm 0.3$ & $50.6 \pm 12^{\mathrm{a}}$ \\
T. lutea & $6.8 \pm 0.3$ & $21.7 \pm 8^{\mathrm{b}}$ \\
Te. chui & $6.8 \pm 0.3$ & $28.4 \pm 6^{\mathrm{b}}$ \\
\hline
\end{tabular}

Table 2. Microalgal cells dry weight in pg.cell ${ }^{-1}$, final survival (mean $\pm \mathrm{SE}$ ), percentage of weight gain (PerWG.larvae ${ }^{-1}$, mean $\pm \mathrm{SE}$ ) in \% after 8 days of feeding experiment, and growth rate (SGR, mean $\pm \mathrm{SE}$ ) in $\mu \mathrm{g}$.larvae ${ }^{-1}$.day $^{-1}$ of white shrimp larvae fed on Indonesian microalgae strains, $C$. neogracile, T. lutea and Te. chui during protozoea stages. Numbers with same superscript letters in column indicate lack of significant differences (one way ANOVA, $\mathrm{p}=0.05$ and Tukey test)

\begin{tabular}{lllll}
\hline Strain & Dry weight & Final survival & Percent WG & SGR \\
\hline Kb1-3 & 20.7 & $11 \pm 1^{\mathrm{ab}}$ & $70 \pm 6^{\mathrm{a}}$ & $0.23 \pm 0.003^{\mathrm{a}}$ \\
Kb1-5 & 15.6 & $7 \pm 2^{\mathrm{b}}$ & $108 \pm 5^{\mathrm{a}}$ & $0.29 \pm 0.002^{\mathrm{a}}$ \\
C. neogracile & 30.8 & $13 \pm 9^{\mathrm{ab}}$ & $69 \pm 20^{\mathrm{a}}$ & $0.23 \pm 0.003^{\mathrm{a}}$ \\
T. lutea & 21.8 & $31 \pm 12^{\mathrm{a}}$ & $39 \pm 12^{\mathrm{b}}$ & $0.15 \pm 0.003^{\mathrm{b}}$ \\
Te. chui & 94.2 & $20 \pm 9^{\mathrm{ab}}$ & $37 \pm 10^{\mathrm{b}}$ & $0.16 \pm 0.004^{\mathrm{b}}$ \\
\hline
\end{tabular}


Table 3. Food supplied (FS), food ingested (FI), weight gain (WG), food conversion index (FCI) and gross growth efficiency $\left(k_{1}\right)$ of individual white shrimp larvae fed four Indonesian microalgae strains and three control species. Numbers with same superscript letters in column indicate lack of significant differences (one way ANOVA, $\mathrm{p}=0.05$ and Tukey test)

\begin{tabular}{|c|c|c|c|c|c|c|c|c|}
\hline \multirow{2}{*}{$\begin{array}{l}\text { Microalgae } \\
\text { strains }\end{array}$} & \multicolumn{2}{|l|}{ FS } & \multicolumn{3}{|c|}{ FI } & \multirow[t]{2}{*}{$\mathrm{WG} \pm \mathrm{SE}$} & \multirow[t]{2}{*}{$\mathrm{FCI} \pm \mathrm{SE}$} & \multirow[t]{2}{*}{$k_{l} \pm \mathrm{SE}$} \\
\hline & $\mathrm{N}$ & DW & $\mathrm{N}$ & DW & $\% \pm \mathrm{SE}$ & & & \\
\hline Kb1-3 & 8.8 & 182 & 4 & 93 & $51 \pm 1^{b}$ & $39 \pm 5^{\mathrm{ab}}$ & $5 \pm 0.1^{\mathrm{a}}$ & $43 \pm 6^{b}$ \\
\hline Kb1-5 & 8.8 & 137 & $\begin{array}{l}5 \\
5\end{array}$ & 84 & $61 \pm 3^{a}$ & $64 \pm 4^{\mathrm{a}}$ & $2 \pm 0.3^{\mathrm{a}}$ & $46 \pm 6^{\mathrm{a}}$ \\
\hline C. neogracile & 8.8 & 271 & $\begin{array}{l}4 \\
4\end{array}$ & 144 & $53 \pm 0^{\mathrm{b}}$ & $43 \pm 11^{\mathrm{a}}$ & $7 \pm 31^{a}$ & $30 \pm 7^{\mathrm{bc}}$ \\
\hline T. lutea & 8.8 & 192 & $\begin{array}{l}7 \\
4\end{array}$ & 98 & $51 \pm 0^{\mathrm{b}}$ & $21 \pm 7^{b}$ & $18 \pm 3^{\mathrm{a}}$ & $22 \pm 8^{c}$ \\
\hline Te. chui & 8.8 & 829 & $\begin{array}{l}5 \\
5\end{array}$ & 514 & $62 \pm 0^{\mathrm{a}}$ & $21 \pm 5^{\mathrm{b}}$ & $53 \pm 10^{\mathrm{b}}$ & $16 \pm 1^{d}$ \\
\hline & & & J & & & & & \\
\hline
\end{tabular}

$\mathrm{N}=$ total amount of microalgae cells supplied (FS) in $10^{6} \cdot$ larvae $^{-1}$ and in $\mu$ g.larvae ${ }^{-1}$, ingested (FI) in $10^{6}$ larvae $e^{-1}$ and in $\%$, DW=Dry weight of algae from total cells supplied and ingested in $\mu \mathrm{g}$.larvae $\mathrm{e}^{-1}$, WG in $\mu \mathrm{g}$.larvae ${ }^{-1}$ calculated as the mean of three replicates at the end of experiment. 


\section{FIGURE LEGENDS}

Figure 1. Survival of the shrimp larvae over the eight-day experiment. Standard errors (SE) about the mean are for 3 replicates except for unfed-control that is for 2 replicates.

SE are indicated by error bars symbol. 
Figure 1

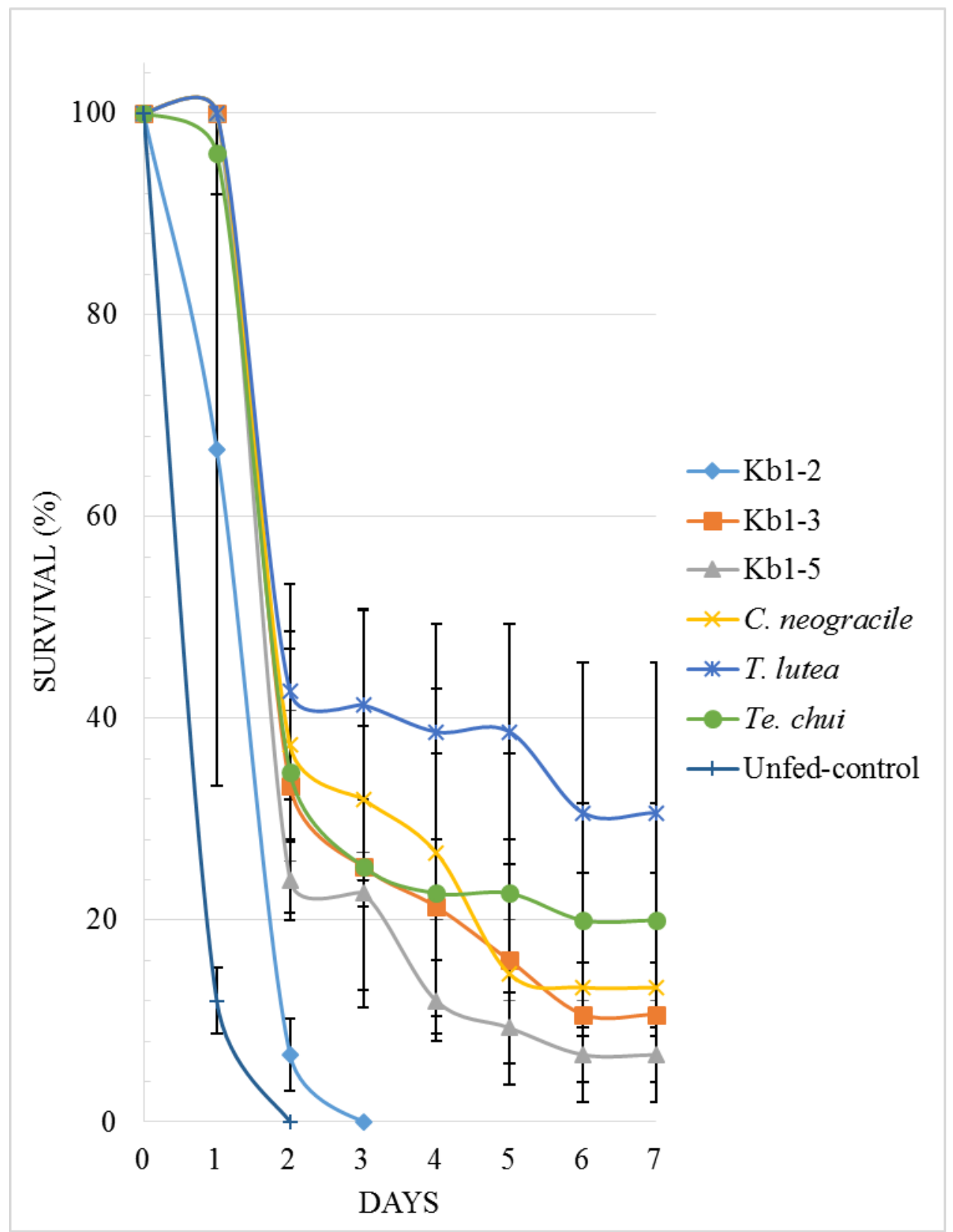




\title{
CHAPTER 5
}

\section{DISCUSSION}

\author{
By \\ Wa Iba \\ College of Environment and Life Sciences \\ Department of Fisheries, Animal and Veterinary Sciences, Kingston Campus, Rhode \\ Island 02881
}




\section{DISCUSSION}

The use of live microalgae in aquaculture hatcheries, is very important for normal growth and development of the larvae, and so far has remained irreplaceable. Although some forms of preserved microalgae, i.e. frozen, dried, powder, have been explored for use for the rearing of larval stages of aquaculture species, they still cannot fully replace the living forms of microalgae (Gallardo et al. 2002; Sanchez et al. 2012; Ma and Qin, 2012; Arney et al. 2015; Gui et al. 2015; Southgate et al. 2016). We know that well-established microalgal strains that have been used in aquaculture belong to sixteen genera (Gopakumar and Ignatius, 2006) and out of them, only seven genera/strains have been used for shrimp aquaculture (Hemaiswarya et al. 2011). Isolation and use of local microalgal strains had been explored for their potential for use in local aquaculture operations (Renaud et al. 1991; Brown et al. 1997; Borowitzka, 1997; Nuñez et al. 2002). In shrimp hatcheries, live microalgae are used to feed larval stages from protozoea up to mysis stages and usually are cultured on site in the hatchery. Therefore, the availability of starter culture and subsequently the continuous or semi continuous microalgal culture in hatchery is very critical. Worldwide, widely known and used microalgae strains usually come from well-established hatchery, marine laboratory and algae centers, then shipped to the local hatchery to be scaled up and finally fed them to shrimp larvae.

Indonesia with its largest archipelagic seas of any country in the world with varies marine microhabitats provides a good opportunity for bioprospecting for new strains of microalgae that may be useful as live feeds for aquaculture. South East (SE) Sulawesi province on Sulawesi Island is one such location in Indonesia with the 
potential to be explored as source of microalgal isolates for aquaculture because of its abundant marine resources in form of bays and coastal waters. Availability of local isolates that meet nutritional requirements of aquaculture species will reduce production cost and ensure that exotic strains that may harbor unknown bacteria and parasites will not enter local waters. This dissertation sought to explore these potential by: a) isolating, culturing, and partially characterizing algal strains from the Kendari region of Southeast Sulawesi; b) characterizing nutritional content of the new Indonesian microalgal isolates in varied culture environments and c) growing these newly isolated microalgae strains form SE-Sulawesi under controlled nutrient conditions and feeding those strains to white shrimp larvae (Litopenaues vannamei) as a model.

Previous studies have shown that environmental factors regulating the growth and production of microalgae under controlled conditions include light intensity, salinity, temperature and composition and concentration of nutrients in culture medium (Renaud and Parry, 1994; Borowitzka, 1997; Renaud et al. 1999; Hu, 2004). Salinity is considered to be a critical factor affecting microalgal growth and its effects are dependent upon the strain. Two groups of microalgal strains respond to high salinity are halophilic species require high salinity for optimum growth, and halotolerant strains have the ability to survive in saline medium but may have lower salinity optima (Rao et al. 2007). The ability of strains to thrive in highly variable salinity conditions while producing optimum nutrition is desirable for aquaculture and evidence has sown that some newly isolated microalgae possess those traits (Lee and Kim, 2002; Khatoon et al. 2014 Ruangsomboon et al. 2013; Borowitzka, 2013) 
The results from microalgal growth experiments presented here show that Indonesian microalgae had similar growth across low and high salinity level suggesting that they are euryhaline or halotolerant species. Their growth is most likely limited by other environmental factors such as light intensity, temperature and culture nutrients, which were not addressed in this work (Hu et al. 1998; Lee and Kim, 2002; Wood, 2005; Rynearson et al. 2009; Whittaker et al. 2012). Differences in final cell density, thus dry weight and ash free dry weight, may be driven by cell size, cell density at inoculation and harvest time. Richmond (2004) stated that output rate, i.e. yield of a microalgal culture, using Spirulina as a model, changed over time, becoming lower as the growth rate decreased during stationary phase of the culture cycle. In this study, Kb1-5 with the smallest cell sizes and the lowest weight per cell among all strains, yet with higher inoculated cell numbers, showed the highest cell numbers over the culture period, but with considerably lower dry weight and ash free dry weight at the end of experiment. Conversely, T. chui with its larger cell sizes, higher cell weight and lower inoculation numbers exhibited the lowest cell numbers on all days of culture, but consistently exhibited higher dry weights across all salinities tested, except at high 35 psu.

Appropriate cell size and adequate nutrition are important microalgal traits that determine their use in aquaculture (Milamena, 1996; Brown, 2002; Becker, 2004; Nuñez et al. 2002). The results presented here showed that although the cell size of Indonesian microalgal strains was different depending on salinity, cell size variation is still within range desirable for larval shrimps $(1.2-11.8 \mu \mathrm{m}$, considered as either pico or nanoplankton). Feeding experiments with white shrimp larvae fed on Indonesian microalgal strains showed that two Indonesian strains, Kb1-3 and Kb1-5, were ingested 
at rates similar to Tiostrea lutea, a widely used species in aquaculture hatcheries. Indonesian strains also showed a comparable weight gain and survival to Chaetoceros neogracile and Tetraselmis chui suggested that these strains were digested and utilized by white shrimp larvae for growth.

Growth and survival of white shrimp were known to be affected by the nutrition content of microalgae as their food (Coutteau, 1996; Nuñez et al. 2002; Brown, 2002; Jamali et al. 2015). It is known that the nutrition of microalgae is varied depend on the strains as well as their culture condition such as temperature, light intensity, culture medium and salinity (Renaud and Parry, 1994; Renaud et al. 1999; Brown, 2002; de Castro Araujo et al. 2005; Khatoon et al. 2010; Zhila et al. 2011; Ruangsomboon et al. 2013; Khatoon et al. 2014). The results from the microalgal nutrition experiments presented here showed that proximate composition of Indonesian microalgae is affected by salinity with variation showed within the individual strains. The nutritional content of Indonesian microalgae, as well as T. lutea, during stationary phase contained protein higher than required by shrimp larvae (ca. 25\%), with comparable lipid and carbohydrate contents (around 10 and 5\%, respectively), as suggested by TobiasQuinito and Villegas (1982).

The results presented here also showed that Indonesian microalgae contained polyunsaturated fatty acids (PUFA), $\omega-3$, eicosapentaenoic acid and docosahexaenoic acid, (EPA and DHA) and $\omega-6$, arachidonic acid (ARA), at 25 and 35 psu and were not all detected other culture salinities tested. Indonesian microalgae had a similar DHA concentration with $T$. lutea but higher ARA concentration. ARA was not detected at all salinities tested in T. lutea in this study but it had a higher EPA concentration compared 
to Indonesian microalgal strains. This may be a factor that contributed to reasonable weight gain of shrimp larvae up to mysis stage when feeding on Indonesian strains of microalgae as showed in our feeding experiments. These weight gains in shrimp was comparable to shrimp in the study by Piña et al. (2006) although the survival was considerably lower. However, survival rate of shrimp larvae feed on two Indonesian strains was similar to the control cultures of $C$. neogracile and Te. chui. Nevertheless, these results and other results in studies summarized by Mata et al. (2010) suggested that the differences in biochemical composition in microalgae is not only determined by culture salinity, but also by the differences in strains that may be attributed to genetic differences. Therefore this is a promising result for exploring other local microalgal strains because there will be a chance to find several good strains for broad applications.

Another interesting results in microalgal nutrition experiment is the presence of phthalic acid in all Indonesian microalgae strains. Phthalic acid is a dicarboxylic acid that usually found as aerosol in the atmosphere (Mochida et al. 2003) or as a product of diisobutyl phthalate (DiBP) hydrolysis through enzyme esterase (Ding et al. 2015). DiBP is one form of plasticizer phthalate esters (PAEs) that have become a public concern because of their effects on environmental contamination and toxicity on mammals (Ding et al. 2015). The C8 and C9 DCAs include phthalic acid have been proposed as oxidation products of unsaturated fatty acids such as oleic acid (Kawamura and Gagosian, 1987; Stephanou and Stratigakis, 1993). The presence of phthalic acid in all Indonesian microalgae may be an indicator that these strains were either able to hydrolyze DiBP by using specific enzymes or they were formed as a result of routine housekeeping activity of oxidizing unsaturated fatty acids. 
There has been a growing interest in Indonesia to find and develop local microalgal strains that maybe used for broad applications beyond aquaculture. The main bottleneck for this research in Indonesia is lack of expertise and available facilities. Training of individuals to be an experts in this area may help to better utilize local microalgal resources in support existing industries and at the same time open new opportunities to develop new industries to grow both the local and national economies. This work confirmed that local strains are potential to be utilized for white shrimp hatcheries based upon their appropriate cells size, robust growth under wide salinity regimes and considerably good nutrition values in terms of macro molecules, protein, lipid and carbohydrate. Furthermore, culturing the local microalgae strains at salinity 35 psu for Kb1-2 and Kb1-3 and at 25 psu for Kb1-5 will ensure that the yield will be optimal while maintaining their good nutritional values as feed for shrimp larvae. The use of these strains in white shrimp hatcheries can be in conjunction with other widely used species in aquaculture such as T. lutea that had higher concentration of EPA when cultured in the condition described in this study. Also, establishing repository for local microalgae in Indonesia, particularly in Kendari where the microalgal samples in this study was obtained, will be necessary to ensure continuous supply of high quality microalgal strains to the local hatcheries as well as to provide other researchers for broader application of microalgae. 


\section{References}

Arney B, Liu W, Forster IP, McKinley RC, Pearce CM. 2015. Feasibility of dietary substitution of live microalgae with spray-dried Schizochytrium sp. or Spirulina in the hatchery culture of juveniles of the Pacific geoduck clam (Panopea generosa). Aquaculture 444:117-133

Becker W. 2004. Microalgae for aquaculture: the nutritional value of microalgae for aquaculture. In Richmond, A. (Ed) Handbook of microalgal culture: biotechnology and applied phycology. Blackwell Publishing Ltd. Iowa. USA, pp 380-391.

Brown, M.R., S.W Jeffrey, J.K. Volkman and G.A. Dunstan. 1997. Nutritional properties of microalgae for mariculture. Aquaculture 151:315-331.

Brown MR. 2002. Nutritional value of microalgae for aquculture. In Cruz-Suárez LE, Ricque-Marie D, Tapia-Salazar M, Gaxiola-Cortés, MG. \& Simoes, N. (eds.). Avances en Nutrición Acuícola VI. Memorias del VI Simposium Internacional de Nutrición Acuícola. 3 al 6 de Septiembre del 2002. Cancún, Quintana Roo, México

Borowitzka, MA. 1997. Microalgae for aquaculture: Opportunities and constraints. Journal of Applied Phycology. 9: 393-401

Borowitzka, M.A. 2013. High-value products from microalgae-their development and commercialization. Journal of Applied Phycology 25:743-756.

Coutteau, P. 1996. Microalage. In Manual on the production and use of live food in aquaculture. FAO Technical paper no 361. Lavens, P., Sorgeloos, P (eds). FAO Rome, Italy. pp 7-48.

Ding J, Wang C, Xie Z, Li J, Yang Y, Mu Y. 2015. Properties of a newly identified esterase from Bacillus sp. K91 and Its Novel Function in Diisobutyl Phthalate Degradation. PLoS ONE 10(3): e0119216.

de Castro Araujo, S and V.N. Tavano Garcia. 2005. Growth and biochemical composition of the diatom Chaetoceros cf.wighamii brightwell under different temperature, salinity and carbon dioxide levels. I. Protein, carbohydrates and lipids. Aquaculture 246:405-412.

Gallardo PP, Pedroza-Islas R, Garcia-Galano T, Pascual T, Rosal C, Sanchez A, Gaxiola, G (2002) Replacement of live food with microbound diet in feeding Litopaneus setiferus (Burkenroad) larvae. Aquaculture Research 33:681-691

Gui Y, Zamora L, Dunphy BJ, Jeffs AG (2015) Evaluation of the formulated diet MySpat for feeding hatchery-reared spat of the green-lipped mussel, Perna canaliculus (Gmelin, 1791). Aquaculture Research 1-6 
Gopakumar, G and B. Ignatius. 2006. Live feed production for marine aquaculture: status, problems and prospects In: Sustain Fish: Proceedings of the International symposium on improved sustainability of fish production systems and appropriate technologies for utilization, 16-18 March, 2005 (eds. B.M. Kurup and K. Ravindran), pp 230-239. School of Industrial Fisheries. Cochin University of Science and Technology. Cochin, India.

Hemaiswarya S, Raja R, Kumar RR, Ganesan V, Anbazhagan C. 2011. Microalgae: a sustainable feed source for aquaculture. World Journal of Microbiology and Biotechnology 27:1737-1746.

Hu, Q., 2004. Environmental effects on cell composition. In: Richmond, A. (Ed.), Handbook of microalgal culture: biotechnology and applied phycology. Blackwell Publishing Ltd., Oxford, pp. 83-94.

Jamali H, Ahmadifard N, Abdollahi, D. 2015. Evaluation of growth, survival and body composition of larval white shrimp (Litopenaeus vannamei) fed the combination of three types of algae. International Aquatic Research 7:115-122

Kawamura, K., and R. B. Gagosian. 1987. Implications of $₫$-oxocarboxylic acids in the remote marine atmosphere for photo-oxidation of unsaturated fatty acids. Nature. 325, 330- 332

Khatoon, H., S. Banerjee, F. Md Yusoff and M. Shariff. 2010. Effects of salinity on the growth and proximate composition of selected tropical marine periphytic diatoms and cyanobacteria. Aquaculture Research 41:1348-1355.

Khatoon, H., Rahman, N.A., Banerjee, S., Harun, N., Suleiman, S.S., Zakaria, N.H., Lananan, F., Hamid, S.H.A., Endut. A. 2014. Effects of different salinities and pH on the growth and proximate composition of Nannochloropsis sp. and Tetraselmis sp. isolated from South China Sea cultured under control and natural condition. International Biodeterioration \& Biodegradation. 95, 11e18

Lee JB, Kim BY (2002) Growth characteristics of five microalgal species isolated from Jeju Island and four microalgal stock strains in hatchery. Algae 17: 117-125

Ma Z, Qin, JG. 2012. Replacement of fresh algae with commercial formulas to enrich rotifers in larval rearing of yellowtail kingfish Seriola lalandi (Valenciennes, 1833). Aquaculture Research 45:949-960

Mata, T. M., Martins, A.A., Caetano, N.S. 2010. Microalgae for biodiesel production and other applications: A review. Renewable and Sustainable Energy Reviews. $14,217-232$

Millamena, O.M. 1996. Review of SEAFDEC/AQD fish nutrition and feed development research. In: Feeds for Small-Scale Aquaculture. Proceedings of the National Seminar-Workshop on Fish Nutrition and Feeds (eds. C. B.Santiago, R.M. 
Coloso, O.M. Millamena and I.G. Borlongan), pp. 52-63. SEAFDEC Aquaculture Department,Iloilo. Philippines

Mochida, M., A. Kawabata, K. Kawamura, H. Hatsushika, and K. Yamazaki, Seasonal variation and origins of dicarboxylic acids in the marine atmosphere over the western North Pacific, J. Geophys. Res., 108 (D6), 4193.

Nuñez M, Lodeiros C, De Donato M, Graziani C. 2002. Evaluation of microalgae diets for Litopenaeus vannamei larvae using a simple protocol. Aquaculture International 10:177-187

Piña P, Voltolina D, Nieves M, Robles M (2006) Survival, development and growth of the Pacific white shrimp Litopenaeus vannamei protozoea larvae, fed with monoalgal and mixed diets. Aquaculture 253:523-530.

Rao, AR., Dayananda, C., Sarada, R., Shamala, TR., Ravishankar, GA. 2007. Effect of salinity on growth of green alga Botryococcus braunii and its constituents. Bioresource Technology. 98: 560-564

Renaud, S.M., D.L. Parry, T. Luong-Van, C. Kuo, A. Padovan and N. Sammy. 1991. Effect of light intensity on the proximate biochemical and fatty acid composition of Isochrysis sp. and Nannochloropsis oculata for use in tropical aquaculture. Journal of Applied Phycology 3:43-53.

Renaud, S. M. Parry, D. L. 1994. Microalgae for use in tropical aquaculture II: Effect of salinity on growth, gross chemical composition and fatty acid composition of three species of marine microalgae. Journal of Applied Phycology 6: 347-356

Renaud, S.M., T. Luong-Van and D.L. Parry. 1999. The gross chemical composition and fatty acid composition of 18 species of tropical Australian microalgae for possible use in mariculture. Aquaculture 170:147-159

Richmond A. 2004. Biological principles of mass cultivation. In Richmond A (ed) Handbook of microalgal culture: biotechnology and applied phycology. Blackwell Publishing Ltd, Iowa, pp 125-177

Ruangsomboon S, Ganmanee M, Choochote S. 2013. Effects of different nitrogen, phosphorus, and iron concentrations and salinity on lipid prcoduction in newly isolated strain of the tropical green microalga, Scenedesmus dimorphus KMITL. J Appl Phycol 25:867-874

Rynearson, T. A., E. O. Lin, and E. V. Armbrust. 2009. Metapopulation Structure in the Planktonic Diatom Ditylum brightwellii (Bacillariophyceae). Protist 160:111-121. 
Southgate PC, Beer AC, Ngaluafe P. 2016. Hatchery culture of the winged pearl oyster, Pteria penguin, without living micro-algae. Short communication. Aquaculture 451:121-124

Stephanou, E. G., and N. Stratigakis. 1993. Oxocarboxylic and a, w-dicarboxylic acids: Photooxidation products of biogenic unsaturated fatty acids present in urban aerosols, Environ. Sci. Technol., 27, 1403- 1407

Tobias-Quinito E., Villegas, C. 1982. Growth, survival and macronutrient composition of Penaeus monodon larvae feed with Chaetoceros calcitrans and Tetraselmis chuii. Aquaculture 25: 253-260

Whittaker, K., D. Rignanese, R. Olson, and T. Rynearson. 2012. Molecular subdivision of the marine diatom Thalassiosira rotula in relation to geographic distribution, genome size, and physiology. BMC Evolutionary Biology 12:209.

Zhila N, Kalacheva G, Volova T. 2011. Effect of salinity on the biochemical composition of the alga Botryococcus braunii Kütz IPPAS H-252. J Appl Phycol. $23: 47-52$ 


\section{APPENDIX}

A. Cells density of Indonesian microalgal strains C. neogracile, T.chui and Ti.lutea cultured at different salinity over 15 days culture period

\begin{tabular}{|c|c|c|c|c|c|c|c|c|}
\hline \multirow[t]{2}{*}{ Strain } & \multirow{2}{*}{$\begin{array}{l}\text { Salinity } \\
\text { (psu) }\end{array}$} & \multicolumn{7}{|c|}{ Cells density (cells $\left.\mathrm{mL} \cdot 10^{5}\right)$ at days of culture } \\
\hline & & 0 & 3 & 6 & 8 & 10 & 13 & 15 \\
\hline Kb1-2 & 20 & 0.6 & 2.7 & 9.7 & 10.9 & 15.1 & 18.0 & 27.7 \\
\hline Kb1-2 & 25 & 0.6 & 2.1 & 7.0 & 7.1 & 6.2 & 6.6 & 5.3 \\
\hline Kb1-2 & 30 & 0.6 & 2.2 & 7.2 & 8.2 & 8.2 & 14.9 & 20.9 \\
\hline Kb1-2 & 35 & 0.6 & 1.7 & 5.7 & 7.9 & 14.3 & 15.3 & 18.4 \\
\hline Kb1-3 & 20 & 0.2 & 0.5 & 5.0 & 12.5 & 25.8 & 34.6 & 39.4 \\
\hline Kb1-3 & 25 & 0.2 & 0.8 & 5.7 & 14.7 & 28.2 & 41.1 & 47.0 \\
\hline Kb1-3 & 30 & 0.3 & 0.7 & 5.4 & 14.1 & 28.1 & 34.7 & 40.6 \\
\hline Kb1-3 & 35 & 0.3 & 0.5 & 5.9 & 17.5 & 35.0 & 63.4 & 65.9 \\
\hline Kb1-5 & 20 & 1.3 & 8.2 & 21.5 & 11.9 & 15.7 & 39.4 & 27.5 \\
\hline Kb1-5 & 25 & 0.9 & 7.2 & 19.1 & 42.4 & 28.7 & 13.4 & 18.2 \\
\hline Kb1-5 & 30 & 1.2 & 6.7 & 39.7 & 16.9 & 7.5 & 15.7 & 9.4 \\
\hline Kb1-5 & 35 & 0.8 & 6.1 & 15.9 & 36.6 & 32.3 & 24.0 & 26.7 \\
\hline C. neogracile & 20 & 0.0 & 0.1 & 0.7 & 2.4 & 5.5 & 9.4 & 11.1 \\
\hline C. neogracile & 25 & 0.0 & 0.2 & 0.8 & 2.3 & 5.2 & 9.0 & 11.0 \\
\hline C. neogracile & 30 & 0.0 & 0.1 & 0.8 & 2.1 & 5.6 & 9.5 & 11.3 \\
\hline C. neogracile & 35 & 0.1 & 0.1 & 0.8 & 3.0 & 6.1 & 11.1 & 13.0 \\
\hline T. chui & 20 & 0.1 & 0.1 & 0.5 & 1.0 & 2.4 & 4.3 & 4.5 \\
\hline T. chui & 25 & 0.1 & 0.0 & 0.7 & 1.5 & 1.9 & 3.0 & 3.8 \\
\hline T. chui & 30 & 0.1 & 0.0 & 0.6 & 3.5 & 3.5 & 5.7 & 6.1 \\
\hline T. chui & 35 & 0.1 & 0.1 & 0.8 & 2.2 & 4.3 & 6.5 & 7.8 \\
\hline Ti. lutea & 20 & 0.7 & 0.7 & 1.4 & 3.6 & 11.3 & 10.6 & 11.2 \\
\hline Ti. lutea & 25 & 0.7 & 0.7 & 1.3 & 3.8 & 10.6 & 14.3 & 15.2 \\
\hline Ti. lutea & 30 & 0.7 & 0.8 & 1.4 & 4.1 & 11.6 & 13.8 & 12.5 \\
\hline Ti. lutea & 35 & 0.7 & 0.7 & 1.1 & 2.2 & 6.7 & 16.9 & 15.4 \\
\hline
\end{tabular}


B. Fluoresence and cells density of Kb1-2 strain

\begin{tabular}{|c|c|c|c|c|}
\hline Day & Salinity & Replicate & Fluorosence & Cells.mL $10^{-5}$ \\
\hline \multirow[t]{16}{*}{1} & 20 & 1 & 8.665 & 0.6 \\
\hline & & 2 & 8.61 & 0.6 \\
\hline & & 3 & 8.036 & 0.6 \\
\hline & & 4 & 8.557 & 0.6 \\
\hline & 25 & 1 & 9.058 & 0.6 \\
\hline & & 2 & 9.282 & 0.7 \\
\hline & & 3 & 9.529 & 0.7 \\
\hline & & 4 & 8.672 & 0.6 \\
\hline & 30 & 1 & 7.894 & 0.6 \\
\hline & & 2 & 9.735 & 0.7 \\
\hline & & 3 & 9.068 & 0.6 \\
\hline & & 4 & 9.715 & 0.7 \\
\hline & 35 & 1 & 7.755 & 0.5 \\
\hline & & 2 & 7.841 & 0.5 \\
\hline & & 3 & 9.399 & 0.7 \\
\hline & & 4 & 9.442 & 0.7 \\
\hline \multirow[t]{16}{*}{3} & 20 & 1 & 42.61 & 3.0 \\
\hline & & 2 & 35.33 & 2.5 \\
\hline & & 3 & 39.86 & 2.8 \\
\hline & & 4 & 35.61 & 2.5 \\
\hline & 25 & 1 & 29.18 & 2.0 \\
\hline & & 2 & 31.15 & 2.2 \\
\hline & & 3 & 32.51 & 2.3 \\
\hline & & 4 & 28.09 & 2.0 \\
\hline & 30 & 1 & 25.66 & 1.8 \\
\hline & & 2 & 34.28 & 2.4 \\
\hline & & 3 & 31.24 & 2.2 \\
\hline & & 4 & 36.27 & 2.5 \\
\hline & 35 & 1 & 21.82 & 1.5 \\
\hline & & 2 & 20.97 & 1.5 \\
\hline & & 3 & 27.62 & 1.9 \\
\hline & & 4 & 24.77 & 1.7 \\
\hline \multirow[t]{6}{*}{6} & 20 & 1 & 136.5 & 9.6 \\
\hline & & 2 & 137.4 & 9.6 \\
\hline & & 3 & 170 & 11.9 \\
\hline & & 4 & 108 & 7.6 \\
\hline & 25 & 1 & 111 & 7.8 \\
\hline & & 2 & 100.3 & 7.0 \\
\hline
\end{tabular}




\begin{tabular}{|c|c|c|c|c|}
\hline & & 3 & 74.2 & 5.2 \\
\hline & & 4 & 114.1 & 8.0 \\
\hline & 30 & 1 & 100.1 & 7.0 \\
\hline & & 2 & 112.1 & 7.9 \\
\hline & & 3 & 88.76 & 6.2 \\
\hline & & 4 & 110.4 & 7.7 \\
\hline & 35 & 1 & 67.9 & 4.8 \\
\hline & & 2 & 64.44 & 4.5 \\
\hline & & 3 & 91.4 & 6.4 \\
\hline & & 4 & 102.8 & 7.2 \\
\hline \multirow[t]{16}{*}{8} & 20 & 1 & 191.5 & 13.4 \\
\hline & & 2 & 136.8 & 9.6 \\
\hline & & 3 & 136 & 9.5 \\
\hline & & 4 & 160 & 11.2 \\
\hline & 25 & 1 & 124.8 & 8.7 \\
\hline & & 2 & 99.58 & 7.0 \\
\hline & & 3 & 67.07 & 4.7 \\
\hline & & 4 & 113.4 & 7.9 \\
\hline & 30 & 1 & 118.1 & 8.3 \\
\hline & & 2 & 110.3 & 7.7 \\
\hline & & 3 & 108.6 & 7.6 \\
\hline & & 4 & 129.9 & 9.1 \\
\hline & 35 & 1 & 108.5 & 7.6 \\
\hline & & 2 & 95.54 & 6.7 \\
\hline & & 3 & 119.2 & 8.4 \\
\hline & & 4 & 128.1 & 9.0 \\
\hline \multirow[t]{15}{*}{10} & 20 & 1 & 157.1 & 11.0 \\
\hline & & 2 & 178.2 & 12.5 \\
\hline & & 3 & 291.1 & 20.4 \\
\hline & & 4 & 234.1 & 16.4 \\
\hline & 25 & 1 & 94.41 & 6.6 \\
\hline & & 2 & 86 & 6.0 \\
\hline & & 3 & 90.16 & 6.3 \\
\hline & & 4 & 85.27 & 6.0 \\
\hline & 30 & 1 & 164.2 & 11.5 \\
\hline & & 2 & 198.4 & 13.9 \\
\hline & & 3 & 203.8 & 14.3 \\
\hline & & 4 & 194.2 & 13.6 \\
\hline & 35 & 1 & 188.3 & 13.2 \\
\hline & & 2 & 182.6 & 12.8 \\
\hline & & 3 & 230 & 16.1 \\
\hline
\end{tabular}




\begin{tabular}{|c|c|c|c|c|}
\hline & & 4 & 212.9 & 14.9 \\
\hline \multirow[t]{16}{*}{13} & 20 & 1 & 270.5 & 18.9 \\
\hline & & 2 & 277.1 & 19.4 \\
\hline & & 3 & 243.8 & 17.1 \\
\hline & & 4 & 235.6 & 16.5 \\
\hline & 25 & 1 & 90.25 & 6.3 \\
\hline & & 2 & 96.58 & 6.8 \\
\hline & & 3 & 111.2 & 7.8 \\
\hline & & 4 & 77.23 & 5.4 \\
\hline & 30 & 1 & 223.2 & 15.6 \\
\hline & & 2 & 202.3 & 14.2 \\
\hline & & 3 & 226.1 & 15.8 \\
\hline & & 4 & 199.8 & 14.0 \\
\hline & 35 & 1 & 206.9 & 14.5 \\
\hline & & 2 & 195.8 & 13.7 \\
\hline & & 3 & 245.2 & 17.2 \\
\hline & & 4 & 223.9 & 15.7 \\
\hline \multirow[t]{16}{*}{15} & 20 & 1 & 385 & 27.0 \\
\hline & & 2 & 339 & 23.7 \\
\hline & & 3 & 412 & 28.9 \\
\hline & & 4 & 445.5 & 31.2 \\
\hline & 25 & 1 & 64.16 & 4.5 \\
\hline & & 2 & 75.03 & 5.3 \\
\hline & & 3 & 101.5 & 7.1 \\
\hline & & 4 & 59.97 & 4.2 \\
\hline & 30 & 1 & 315.9 & 22.1 \\
\hline & & 2 & 245.2 & 17.2 \\
\hline & & 3 & 294.9 & 20.7 \\
\hline & & 4 & 338.4 & 23.7 \\
\hline & 35 & \begin{tabular}{|l|l}
1 \\
\end{tabular} & 241.4 & 16.9 \\
\hline & & 2 & 321.75 & 22.5 \\
\hline & & 3 & 227.9 & 16.0 \\
\hline & & 4 & 257.3 & 18.0 \\
\hline
\end{tabular}


C. Fluoresence and cells density of Kb1-3 strain

\begin{tabular}{|c|c|c|c|c|}
\hline Day & Salinity & Replicate & Fluorescence & Cells.mL $10^{-5}$ \\
\hline \multirow[t]{16}{*}{1} & 20 & 1 & 0.707 & 0.2 \\
\hline & & 2 & 0.776 & 0.2 \\
\hline & & 3 & 0.742 & 0.2 \\
\hline & & 4 & 0.85 & 0.3 \\
\hline & 25 & 1 & 0.726 & 0.2 \\
\hline & & 2 & 0.725 & 0.2 \\
\hline & & 3 & 0.793 & 0.2 \\
\hline & & 4 & 0.766 & 0.2 \\
\hline & 30 & 1 & 0.709 & 0.2 \\
\hline & & 2 & 0.921 & 0.3 \\
\hline & & 3 & 0.872 & 0.3 \\
\hline & & 4 & 0.855 & 0.3 \\
\hline & 35 & 1 & 0.916 & 0.3 \\
\hline & & 2 & 0.919 & 0.3 \\
\hline & & 3 & 0.931 & 0.3 \\
\hline & & 4 & 0.997 & 0.4 \\
\hline \multirow[t]{16}{*}{3} & 20 & 1 & 1.348 & 0.6 \\
\hline & & 2 & 1.291 & 0.6 \\
\hline & & 3 & 1.26 & 0.5 \\
\hline & & 4 & 1.092 & 0.4 \\
\hline & 25 & 1 & 1.092 & 0.4 \\
\hline & & 2 & 1.131 & 0.5 \\
\hline & & 3 & 2.318 & 1.2 \\
\hline & & 4 & 2.089 & 1.1 \\
\hline & 30 & 1 & 1.676 & 0.8 \\
\hline & & 2 & 1.251 & 0.5 \\
\hline & & 3 & 1.447 & 0.7 \\
\hline & & 4 & 1.421 & 0.6 \\
\hline & 35 & 1 & 1.097 & 0.4 \\
\hline & & 2 & 1.39 & 0.6 \\
\hline & & 3 & 1.385 & 0.6 \\
\hline & & 4 & 1.127 & 0.4 \\
\hline \multirow[t]{7}{*}{6} & 20 & 1 & 3.033 & 1.7 \\
\hline & & 2 & 7.429 & 4.4 \\
\hline & & 3 & 15.6 & 9.6 \\
\hline & & 4 & 7.495 & 4.5 \\
\hline & 25 & 1 & 2.047 & 1.0 \\
\hline & & 2 & 9.022 & 5.4 \\
\hline & & 3 & 12.96 & 7.9 \\
\hline
\end{tabular}




\begin{tabular}{|c|c|c|c|c|}
\hline & & 4 & 13.54 & 8.3 \\
\hline & 30 & 1 & 10.43 & 6.3 \\
\hline & & 2 & 4.866 & 2.8 \\
\hline & & 3 & 12.91 & 7.9 \\
\hline & & 4 & 7.657 & 4.6 \\
\hline & 35 & 1 & 10.62 & 6.5 \\
\hline & & 2 & 12.29 & 7.5 \\
\hline & & 3 & 8.462 & 5.1 \\
\hline & & 4 & 7.724 & 4.6 \\
\hline \multirow[t]{16}{*}{8} & 20 & 1 & 4.771 & 2.8 \\
\hline & 20 & 2 & 17.5 & 10.8 \\
\hline & 20 & 3 & 38.32 & 24.0 \\
\hline & 20 & 4 & 19.85 & 12.3 \\
\hline & 25 & 1 & 8.088 & 4.9 \\
\hline & 25 & 2 & 21.57 & 13.4 \\
\hline & 25 & 3 & 32.22 & 20.1 \\
\hline & 25 & 4 & 32.93 & 20.6 \\
\hline & 30 & 1 & 24.27 & 15.1 \\
\hline & 30 & 2 & 13 & 8.0 \\
\hline & 30 & 3 & 33.33 & 20.8 \\
\hline & 30 & 4 & 19.96 & 12.4 \\
\hline & 35 & 1 & 30.84 & 19.3 \\
\hline & 35 & 2 & 33.73 & 21.1 \\
\hline & 35 & 3 & 23.21 & 14.4 \\
\hline & 35 & 4 & 24.24 & 15.1 \\
\hline \multirow[t]{16}{*}{10} & 20 & 1 & 10.32 & 6.3 \\
\hline & 20 & 2 & 35.46 & 22.2 \\
\hline & 20 & 3 & 77.22 & 48.6 \\
\hline & 20 & 4 & 42.04 & 26.3 \\
\hline & 25 & 1 & 18.56 & 11.5 \\
\hline & 25 & 2 & 44.11 & 27.7 \\
\hline & 25 & 3 & 56.12 & 35.3 \\
\hline & 25 & 4 & 60.84 & 38.2 \\
\hline & 30 & 1 & 49.22 & 30.9 \\
\hline & 30 & 2 & 24.31 & 15.1 \\
\hline & 30 & 3 & 67.87 & 42.7 \\
\hline & 30 & 4 & 37.56 & 23.5 \\
\hline & 35 & 1 & 62.59 & 39.3 \\
\hline & 35 & 2 & 64.63 & 40.6 \\
\hline & 35 & 3 & 45.95 & 28.8 \\
\hline & 35 & 4 & 49.46 & 31.0 \\
\hline
\end{tabular}




\begin{tabular}{|c|c|c|c|c|}
\hline \multirow[t]{16}{*}{13} & 20 & 1 & 33.54 & 21.0 \\
\hline & 20 & 2 & 63.45 & 39.9 \\
\hline & 20 & 3 & 86.16 & 54.3 \\
\hline & 20 & 4 & 37.26 & 23.3 \\
\hline & 25 & 1 & 53.45 & 33.6 \\
\hline & 25 & 2 & 85.5 & 53.8 \\
\hline & 25 & 3 & 55.27 & 34.7 \\
\hline & 25 & 4 & 67.22 & 42.3 \\
\hline & 30 & 1 & 48.1 & 30.2 \\
\hline & 30 & 2 & 55.34 & 34.8 \\
\hline & 30 & 3 & 52.83 & 33.2 \\
\hline & 30 & 4 & 64.4 & 40.5 \\
\hline & 35 & 1 & 96.41 & 60.8 \\
\hline & 35 & 2 & 116.6 & 73.5 \\
\hline & 35 & 3 & 87.99 & 55.4 \\
\hline & 35 & 4 & 101.6 & 64.0 \\
\hline \multirow[t]{16}{*}{15} & 20 & 1 & 68.96 & 43.4 \\
\hline & 20 & 2 & 53.03 & 33.3 \\
\hline & 20 & 3 & 84.19 & 53.0 \\
\hline & 20 & 4 & 44.45 & 27.9 \\
\hline & 25 & 1 & 76.16 & 47.9 \\
\hline & 25 & 2 & 78.82 & 49.6 \\
\hline & 25 & 3 & 67.58 & 42.5 \\
\hline & 25 & 4 & 76.36 & 48.1 \\
\hline & 30 & 1 & 49.01 & 30.8 \\
\hline & 30 & 2 & 71.93 & 45.3 \\
\hline & 30 & 3 & 65.2 & 41.0 \\
\hline & 30 & 4 & 72.21 & 45.4 \\
\hline & 35 & 1 & 76.28 & 48.0 \\
\hline & 35 & 2 & 125.2 & 79.0 \\
\hline & 35 & 3 & 100 & 63.0 \\
\hline & 35 & 4 & 116.6 & 73.5 \\
\hline
\end{tabular}


D. Fluoresence and cells density of Kb1-5 strain

\begin{tabular}{|c|c|c|c|c|}
\hline Day & Salinity & Replicate & Fluoresence & Cells.mL $\cdot 10^{-5}$ \\
\hline \multirow[t]{16}{*}{1} & 20 & 1 & 6.398 & 1.0 \\
\hline & & 2 & 7.631 & 1.2 \\
\hline & & 3 & 9.314 & 1.5 \\
\hline & & 4 & 8.812 & 1.4 \\
\hline & 25 & 1 & 5.313 & 0.8 \\
\hline & & 2 & 4.983 & 0.8 \\
\hline & & 3 & 8.336 & 1.3 \\
\hline & & 4 & 5.021 & 0.8 \\
\hline & 30 & 1 & 7.46 & 1.2 \\
\hline & & 2 & 7.543 & 1.2 \\
\hline & & 3 & 7.528 & 1.2 \\
\hline & & 4 & 7.623 & 1.2 \\
\hline & 35 & 1 & 4.918 & 0.8 \\
\hline & & 2 & 6.155 & 1.0 \\
\hline & & 3 & 5.401 & 0.8 \\
\hline & & 4 & 4.789 & 0.7 \\
\hline \multirow[t]{16}{*}{3} & 20 & 1 & \begin{tabular}{|l|}
39.37 \\
\end{tabular} & 6.5 \\
\hline & & 2 & 56.93 & 9.4 \\
\hline & & 3 & 57.74 & 9.5 \\
\hline & & 4 & 46.07 & 7.6 \\
\hline & 25 & 1 & 37.75 & 6.2 \\
\hline & & 2 & 26.51 & 4.3 \\
\hline & & 3 & 58.32 & 9.6 \\
\hline & & 4 & 52.12 & 8.6 \\
\hline & 30 & 1 & 32.53 & 5.3 \\
\hline & & 2 & 33.65 & 5.5 \\
\hline & & 3 & 46.94 & 7.7 \\
\hline & & 4 & 49.92 & 8.2 \\
\hline & 35 & 1 & 40.06 & 6.6 \\
\hline & & 2 & 37.35 & 6.1 \\
\hline & & 3 & 35.01 & 5.7 \\
\hline & & 4 & 35.67 & 5.9 \\
\hline \multirow[t]{7}{*}{6} & 20 & 1 & 148.5 & 24.5 \\
\hline & & 2 & 119.3 & 19.7 \\
\hline & & 3 & 110.5 & 18.2 \\
\hline & & 4 & 141.6 & 23.4 \\
\hline & 25 & 1 & 85.99 & 14.2 \\
\hline & & 2 & 105 & 17.3 \\
\hline & & 3 & \begin{tabular}{|l|}
166.7 \\
\end{tabular} & 27.5 \\
\hline
\end{tabular}




\begin{tabular}{|c|c|c|c|c|}
\hline & & 4 & 105.1 & 17.3 \\
\hline & 30 & 1 & 243.9 & 40.3 \\
\hline & & 2 & 169 & 27.9 \\
\hline & & 3 & 270.2 & 44.7 \\
\hline & & 4 & 276.5 & 45.7 \\
\hline & 35 & 1 & 86.37 & 14.2 \\
\hline & & 2 & 120.9 & 20.0 \\
\hline & & 3 & 99.91 & 16.5 \\
\hline & & 4 & 78.31 & 12.9 \\
\hline \multirow[t]{16}{*}{8} & 20 & 1 & 70.07 & 11.5 \\
\hline & & 2 & 94.58 & 15.6 \\
\hline & & 3 & 49.93 & 8.2 \\
\hline & & 4 & 75.05 & 12.4 \\
\hline & 25 & 1 & 221.2 & 36.6 \\
\hline & & 2 & 269 & 44.5 \\
\hline & & 3 & 341.8 & 56.5 \\
\hline & & 4 & 194.6 & 32.2 \\
\hline & 30 & 1 & 101.5 & 16.7 \\
\hline & & 2 & 75.28 & 12.4 \\
\hline & & 3 & \begin{tabular}{|l|l}
99.87 \\
\end{tabular} & 16.5 \\
\hline & & 4 & 133.8 & 22.1 \\
\hline & 35 & 1 & 205.1 & 33.9 \\
\hline & & 2 & 240.9 & 39.8 \\
\hline & & 3 & 238.2 & 39.4 \\
\hline & & 4 & 201.8 & 33.3 \\
\hline \multirow[t]{16}{*}{10} & 20 & 1 & 67.09 & 11.1 \\
\hline & & 2 & 74.99 & 12.4 \\
\hline & & 3 & 87.59 & 14.4 \\
\hline & & 4 & $\begin{array}{l}151.6 \\
\end{array}$ & 25.0 \\
\hline & 25 & 1 & 221 & 36.5 \\
\hline & & 2 & \begin{tabular}{|l|l}
167.8 \\
\end{tabular} & 27.7 \\
\hline & & 3 & 215.8 & 35.7 \\
\hline & & 4 & 90.46 & 14.9 \\
\hline & 30 & 1 & 60.29 & 9.9 \\
\hline & & 2 & 32.67 & 5.4 \\
\hline & & 3 & 39.21 & 6.4 \\
\hline & & 4 & 50.01 & 8.2 \\
\hline & 35 & 1 & 124.6 & 20.6 \\
\hline & & 2 & 191.5 & 31.6 \\
\hline & & 3 & 188.4 & 31.1 \\
\hline & & 4 & 276.9 & 45.8 \\
\hline
\end{tabular}




\begin{tabular}{|c|c|c|c|c|}
\hline \multirow{16}{*}{13} & 20 & 1 & 221.5 & 36.6 \\
\hline & & 2 & 227.2 & 37.6 \\
\hline & & 3 & 194.4 & 32.1 \\
\hline & & 4 & 310 & 51.3 \\
\hline & 25 & 1 & \begin{tabular}{|l|}
107.9 \\
\end{tabular} & 17.8 \\
\hline & & 2 & 66.64 & 11.0 \\
\hline & & 3 & 106.4 & 17.6 \\
\hline & & 4 & 44.58 & 7.3 \\
\hline & 30 & 1 & 196.2 & 32.4 \\
\hline & & 2 & 28.4 & 4.6 \\
\hline & & 3 & 84.09 & 13.9 \\
\hline & & 4 & 70.78 & 11.7 \\
\hline & 35 & 1 & 91.4 & 15.1 \\
\hline & & 2 & 129.8 & 21.4 \\
\hline & & 3 & 139.7 & 23.1 \\
\hline & & 4 & 219.7 & 36.3 \\
\hline \multirow[t]{16}{*}{15} & 20 & 1 & 136 & 22.5 \\
\hline & & 2 & 134 & 22.1 \\
\hline & & 3 & 150.1 & 24.8 \\
\hline & & 4 & 244.6 & 40.4 \\
\hline & 25 & 1 & 125.4 & 20.7 \\
\hline & & 2 & 85.85 & 14.2 \\
\hline & & 3 & 151.7 & 25.1 \\
\hline & & 4 & 77.97 & 12.9 \\
\hline & 30 & 1 & 297.9 & 49.3 \\
\hline & & 2 & 88.45 & 14.6 \\
\hline & & 3 & 198.8 & 32.9 \\
\hline & & 4 & 179.9 & 29.7 \\
\hline & 35 & 1 & 217.7 & 36.0 \\
\hline & & 2 & 180.8 & 29.9 \\
\hline & & 3 & \begin{tabular}{|l|l}
103.4 \\
\end{tabular} & 17.1 \\
\hline & & 4 & 143.7 & 23.7 \\
\hline
\end{tabular}


E. Fluoresence and cells density of C. neogracile

\begin{tabular}{|c|c|c|c|}
\hline Day & Salinity & Fluorescence & Cells.mL $\cdot 10^{-5}$ \\
\hline 1 & 20 & 0.495 & 0.02 \\
\hline 1 & 20 & 0.53 & 0.02 \\
\hline 1 & 20 & 0.748 & 0.05 \\
\hline 1 & 20 & 0.779 & 0.05 \\
\hline 1 & 25 & 0.73 & 0.04 \\
\hline 1 & 25 & 0.411 & 0.01 \\
\hline 1 & 25 & 0.419 & 0.01 \\
\hline 1 & 25 & 0.539 & 0.02 \\
\hline 1 & 30 & 0.485 & 0.02 \\
\hline 1 & 30 & 0.946 & \begin{tabular}{|l|l|}
0.07 \\
\end{tabular} \\
\hline 1 & 30 & 0.817 & 0.05 \\
\hline 1 & 30 & 0.576 & 0.03 \\
\hline 1 & 35 & 0.919 & 0.06 \\
\hline 1 & 35 & 0.903 & 0.06 \\
\hline 1 & 35 & 0.73 & \begin{tabular}{|l|}
0.04 \\
\end{tabular} \\
\hline 1 & 35 & 0.944 & 0.07 \\
\hline 3 & 20 & 1.158 & 0.09 \\
\hline 3 & 20 & 1.495 & 0.13 \\
\hline 3 & 20 & 1.659 & 0.14 \\
\hline 3 & 20 & 1.87 & 0.17 \\
\hline 3 & 25 & 1.732 & 0.15 \\
\hline 3 & 25 & 1.176 & \begin{tabular}{|l|l|}
0.09 \\
\end{tabular} \\
\hline 3 & 25 & 3.245 & 0.31 \\
\hline 3 & 25 & 1.296 & 0.10 \\
\hline 3 & 30 & 1.367 & 0.11 \\
\hline 3 & 30 & 1.141 & 0.09 \\
\hline 3 & 30 & 1.717 & 0.15 \\
\hline 3 & 30 & 1.347 & 0.11 \\
\hline 3 & 35 & 1.642 & 0.14 \\
\hline 3 & 35 & 1.713 & 0.15 \\
\hline 3 & 35 & 1.115 & 0.08 \\
\hline 3 & 35 & 2.26 & 0.21 \\
\hline 6 & 20 & 5.713 & 0.58 \\
\hline 6 & 20 & 11.4 & 1.18 \\
\hline 6 & 20 & 4.698 & 0.47 \\
\hline 6 & 20 & 6.634 & 0.67 \\
\hline 6 & 25 & 5.764 & 0.58 \\
\hline 6 & 25 & 6.469 & 0.66 \\
\hline 6 & 25 & 14.86 & 1.55 \\
\hline
\end{tabular}




\begin{tabular}{|c|c|c|c|}
\hline 6 & 25 & 5.786 & 0.58 \\
\hline 6 & 30 & 10.26 & 1.06 \\
\hline 6 & 30 & 7.797 & 0.80 \\
\hline 6 & 30 & 6.311 & 0.64 \\
\hline 6 & 30 & 5.399 & 0.54 \\
\hline 6 & 35 & 6.681 & 0.68 \\
\hline 6 & 35 & 4.928 & 0.49 \\
\hline 6 & 35 & 4.336 & 0.43 \\
\hline 6 & 35 & 16.23 & 1.70 \\
\hline 8 & 20 & 14.64 & 1.53 \\
\hline 8 & 20 & 43.94 & 4.66 \\
\hline 8 & 20 & 11.01 & 1.14 \\
\hline 8 & 20 & 22.3 & 2.35 \\
\hline 8 & 25 & 18.22 & 1.91 \\
\hline 8 & 25 & 35.97 & 3.81 \\
\hline 8 & 25 & 13.62 & 1.42 \\
\hline 8 & 25 & 18.56 & 1.95 \\
\hline 8 & 30 & 30.06 & 3.18 \\
\hline 8 & 30 & 25.51 & 2.69 \\
\hline 8 & 30 & 14.77 & 1.54 \\
\hline 8 & 30 & 11.12 & 1.15 \\
\hline 8 & 35 & 24.4 & 2.57 \\
\hline 8 & 35 & 17.51 & 1.84 \\
\hline 8 & 35 & 14.77 & 1.54 \\
\hline 8 & 35 & 55.5 & 5.89 \\
\hline 10 & 20 & 42.42 & 4.50 \\
\hline 10 & 20 & 86.72 & 9.23 \\
\hline 10 & 20 & 27.64 & 2.92 \\
\hline 10 & 20 & 50.14 & 5.32 \\
\hline 10 & 25 & 40.46 & 4.29 \\
\hline 10 & 25 & 55.65 & 5.91 \\
\hline 10 & 25 & 69.1 & 7.35 \\
\hline 10 & 25 & 29.1 & 3.07 \\
\hline 10 & 30 & 91.84 & 9.78 \\
\hline 10 & 30 & 66.03 & 7.02 \\
\hline 10 & 30 & 32.93 & 3.48 \\
\hline 10 & 30 & 21.74 & 2.29 \\
\hline 10 & 35 & 61.05 & 6.49 \\
\hline 10 & 35 & 40.33 & 4.27 \\
\hline 10 & 35 & 32.5 & 3.44 \\
\hline 10 & 35 & 94.6 & 10.07 \\
\hline
\end{tabular}




\begin{tabular}{|c|c|c|c|}
\hline 13 & 20 & 72.78 & 7.74 \\
\hline 13 & 20 & 127.5 & 13.59 \\
\hline 13 & 20 & 62.04 & 6.59 \\
\hline 13 & 20 & 90.03 & 9.58 \\
\hline 13 & 25 & 88.16 & 9.38 \\
\hline 13 & 25 & 81.02 & 8.62 \\
\hline 13 & 25 & 102.1 & 10.87 \\
\hline 13 & 25 & 65.22 & 6.93 \\
\hline 13 & 30 & 112.8 & 12.02 \\
\hline 13 & 30 & 94.76 & 10.09 \\
\hline 13 & 30 & 75.14 & 7.99 \\
\hline 13 & 30 & 73.79 & 7.85 \\
\hline 13 & 35 & 93.71 & 9.98 \\
\hline 13 & 35 & 97.03 & 10.33 \\
\hline 13 & 35 & 92.83 & 9.88 \\
\hline 13 & 35 & 131.7 & 14.04 \\
\hline 15 & 20 & 81.89 & 8.71 \\
\hline 15 & 20 & 148.2 & 15.80 \\
\hline 15 & 20 & 87.79 & 9.34 \\
\hline 15 & 20 & 98.99 & 10.54 \\
\hline 15 & 25 & 100.7 & 10.72 \\
\hline 15 & 25 & 106.7 & 11.36 \\
\hline 15 & 25 & 103.4 & 11.01 \\
\hline 15 & 25 & 103.5 & 11.02 \\
\hline 15 & 30 & 117.7 & 12.54 \\
\hline 15 & 30 & 98.56 & 10.49 \\
\hline 15 & 30 & 105.6 & 11.25 \\
\hline 15 & 30 & 101.4 & 10.80 \\
\hline 15 & 35 & 111.5 & 11.88 \\
\hline 15 & 35 & 116.9 & 12.45 \\
\hline 15 & 35 & 103.4 & 11.01 \\
\hline 15 & 35 & 158.1 & 16.86 \\
\hline
\end{tabular}


F. Fluoresence and cells density of T. chui

\begin{tabular}{|l|l|l|l|}
\hline Days & Salinity & Fluoresence & Cells.mL $\cdot 10^{-5}$ \\
\hline 1 & 20 & 2.006 & 0.11 \\
\hline 1 & 20 & 1.868 & 0.10 \\
\hline 1 & 20 & 1.296 & 0.07 \\
\hline 1 & 20 & 1.603 & 0.09 \\
\hline 1 & 25 & 1.523 & 0.08 \\
\hline 1 & 25 & 2.005 & 0.11 \\
\hline 1 & 25 & 1.199 & 0.07 \\
\hline 1 & 25 & 1.568 & 0.09 \\
\hline 1 & 30 & 1.256 & 0.07 \\
\hline 1 & 30 & 1.24 & 0.07 \\
\hline 1 & 30 & 1.571 & 0.09 \\
\hline 1 & 30 & 1.226 & 0.07 \\
\hline 1 & 35 & 2.339 & 0.13 \\
\hline 1 & 35 & 1.652 & 0.09 \\
\hline 1 & 35 & 1.276 & 0.07 \\
\hline 1 & 35 & 1.42 & 0.08 \\
\hline 3 & 20 & 1.02 & 0.06 \\
\hline 3 & 20 & 1.384 & 0.08 \\
\hline 3 & 20 & 0.802 & 0.04 \\
\hline 3 & 20 & 0.59 & 0.03 \\
\hline 3 & 25 & 1.29 & 0.07 \\
\hline 3 & 25 & 1.197 & 0.07 \\
\hline 3 & 25 & 0.742 & 0.04 \\
\hline 3 & 25 & 1.307 & 0.07 \\
\hline 3 & 30 & 0.359 & 0.02 \\
\hline 3 & 30 & 1.506 & 0.08 \\
\hline 3 & 30 & 0.859 & 0.05 \\
\hline 3 & 30 & 0.783 & 0.04 \\
\hline 3 & 35 & 0.806 & 0.05 \\
\hline 3 & 35 & 1.06 & 0.06 \\
\hline 3 & 35 & 1.031 & 0.06 \\
\hline 3 & 35 & 0.86 & 0.05 \\
\hline 6 & 20 & 7.9 & 0.43 \\
\hline 6 & 20 & 10.55 & 0.57 \\
\hline 6 & 20 & 11.8 & 0.63 \\
\hline 6 & 20 & 9.629 & 0.52 \\
\hline 6 & 25 & 37.67 & 2.02 \\
\hline 6 & 25 & 7.521 & 0.40 \\
\hline 6 & 25 & 13.6 & 0.73 \\
\hline & & & \\
\hline
\end{tabular}




\begin{tabular}{|c|c|c|c|}
\hline 6 & 25 & 20.11 & 1.08 \\
\hline 6 & 30 & 9.45 & 0.51 \\
\hline 6 & 30 & 10.06 & 0.54 \\
\hline 6 & 30 & 13.22 & 0.71 \\
\hline 6 & 30 & 14.06 & 0.76 \\
\hline 6 & 35 & 8.842 & 0.48 \\
\hline 6 & 35 & 14.16 & 0.76 \\
\hline 6 & 35 & 16.77 & 0.90 \\
\hline 6 & 35 & 19.82 & 1.06 \\
\hline 8 & 20 & 18.91 & 1.02 \\
\hline 8 & 20 & 13.03 & 0.70 \\
\hline 8 & 20 & 35.03 & 1.88 \\
\hline 8 & 20 & 10.42 & 0.56 \\
\hline 8 & 25 & 64.39 & 3.45 \\
\hline 8 & 25 & 13.42 & 0.72 \\
\hline 8 & 25 & 40.05 & 2.15 \\
\hline 8 & 25 & 46.44 & 2.49 \\
\hline 8 & 30 & 20.53 & 1.10 \\
\hline 8 & 30 & 35.77 & 1.92 \\
\hline 8 & 30 & 36.05 & 1.93 \\
\hline 8 & 30 & 27.11 & 1.45 \\
\hline 8 & 35 & 13.19 & 0.71 \\
\hline 8 & 35 & 51.42 & 2.76 \\
\hline 8 & 35 & 44.02 & 2.36 \\
\hline 8 & 35 & 55.09 & 2.95 \\
\hline 10 & 20 & 9.325 & 0.50 \\
\hline 10 & 20 & 22.54 & 1.21 \\
\hline 10 & 20 & 90.58 & 4.86 \\
\hline 10 & 20 & 53.58 & 2.87 \\
\hline 10 & 25 & 87.8 & 4.71 \\
\hline 10 & 25 & 14.84 & 0.80 \\
\hline 10 & 25 & 58.79 & 3.15 \\
\hline 10 & 25 & 41.03 & 2.20 \\
\hline 10 & 30 & 34.22 & 1.84 \\
\hline 10 & 30 & 119.4 & 6.40 \\
\hline 10 & 30 & 44.94 & 2.41 \\
\hline 10 & 30 & 60.91 & 3.27 \\
\hline 10 & 35 & 18.35 & 0.99 \\
\hline 10 & 35 & 106.8 & 5.73 \\
\hline 10 & 35 & 76.02 & 4.08 \\
\hline 10 & 35 & 117.7 & 6.31 \\
\hline
\end{tabular}




\begin{tabular}{|c|c|c|c|}
\hline 13 & 20 & 29.67 & 1.59 \\
\hline 13 & 20 & 28.36 & 1.52 \\
\hline 13 & 20 & 151.7 & 8.13 \\
\hline 13 & 20 & 108.2 & 5.80 \\
\hline 13 & 25 & 104.9 & 5.62 \\
\hline 13 & 25 & 29.93 & 1.61 \\
\hline 13 & 25 & 128.4 & 6.88 \\
\hline 13 & 25 & 55.96 & 3.00 \\
\hline 13 & 30 & 40.95 & 2.20 \\
\hline 13 & 30 & 208.7 & 11.19 \\
\hline 13 & 30 & 43.12 & 2.31 \\
\hline 13 & 30 & 134.6 & 7.22 \\
\hline 13 & 35 & 49.87 & 2.67 \\
\hline 13 & 35 & 126.6 & 6.79 \\
\hline 13 & 35 & 88.1 & 4.72 \\
\hline 13 & 35 & 217.5 & 11.66 \\
\hline 15 & 20 & 13.7 & 0.74 \\
\hline 15 & 20 & 16.18 & 0.87 \\
\hline 15 & 20 & 168.3 & 9.02 \\
\hline 15 & 20 & 140.8 & 7.55 \\
\hline 15 & 25 & 157.4 & 8.44 \\
\hline 15 & 25 & 30.4 & 1.63 \\
\hline 15 & 25 & 162.1 & 8.69 \\
\hline 15 & 25 & 61.66 & 3.31 \\
\hline 15 & 30 & 35.77 & 1.92 \\
\hline 15 & 30 & 213.4 & 11.44 \\
\hline 15 & 30 & 29.33 & 1.57 \\
\hline 15 & 30 & 178.2 & 9.55 \\
\hline 15 & 35 & 27.54 & 1.48 \\
\hline 15 & 35 & 123.1 & 6.60 \\
\hline 15 & 35 & 149.2 & 8.00 \\
\hline 15 & 35 & 281.4 & 15.08 \\
\hline
\end{tabular}


G. Fluoresence and cells density of Ti. lutea

\begin{tabular}{|c|c|c|c|}
\hline Day & Salinity & Flourometer & Cells.mL $10^{-5}$ \\
\hline 1 & 20 & 0.144 & 0.7 \\
\hline 1 & 20 & 0.128 & 0.7 \\
\hline 1 & 20 & 0.127 & 0.7 \\
\hline 1 & 20 & 0.106 & 0.7 \\
\hline 1 & 25 & 0.133 & 0.7 \\
\hline 1 & 25 & 0.151 & 0.7 \\
\hline 1 & 25 & 0.167 & 0.7 \\
\hline 1 & 25 & 0.171 & 0.7 \\
\hline 1 & 30 & 0.182 & 0.7 \\
\hline 1 & 30 & 0.177 & 0.7 \\
\hline 1 & 30 & 0.156 & 0.7 \\
\hline 1 & 30 & 0.21 & 0.7 \\
\hline 1 & 35 & 0.026 & 0.7 \\
\hline 1 & 35 & 0.13 & 0.7 \\
\hline 1 & 35 & 0.163 & 0.7 \\
\hline 1 & 35 & 0.145 & 0.7 \\
\hline 3 & 20 & 0.33 & 0.8 \\
\hline 3 & 20 & 0.043 & 0.7 \\
\hline 3 & 20 & 0.326 & 0.8 \\
\hline 3 & 20 & 0.224 & 0.7 \\
\hline 3 & 25 & 0.01 & 0.7 \\
\hline 3 & 25 & 0.401 & 0.8 \\
\hline 3 & 25 & 0.52 & 0.8 \\
\hline 3 & 25 & 0.323 & 0.8 \\
\hline 3 & 30 & 0.349 & 0.8 \\
\hline 3 & 30 & 0.328 & 0.8 \\
\hline 3 & 30 & 0.372 & 0.8 \\
\hline 3 & 30 & 0.383 & 0.8 \\
\hline 3 & 35 & 0.317 & 0.8 \\
\hline 3 & 35 & 0.22 & 0.7 \\
\hline 3 & 35 & 0.176 & 0.7 \\
\hline 3 & 35 & 0.292 & 0.7 \\
\hline 6 & 20 & 2.121 & 1.3 \\
\hline 6 & 20 & 1.736 & 1.2 \\
\hline 6 & 20 & 3.761 & 1.8 \\
\hline 6 & 20 & 2.065 & 1.3 \\
\hline 6 & 25 & 1.628 & 1.1 \\
\hline 6 & 25 & 1.954 & 1.2 \\
\hline 6 & 25 & 3.054 & 1.6 \\
\hline
\end{tabular}




\begin{tabular}{|c|c|c|c|}
\hline 6 & 25 & 2.022 & 1.3 \\
\hline 6 & 30 & 2.77 & 1.5 \\
\hline 6 & 30 & 1.972 & 1.2 \\
\hline 6 & 30 & 2.638 & 1.4 \\
\hline 6 & 30 & 2.693 & 1.5 \\
\hline 6 & 35 & 1.487 & 1.1 \\
\hline 6 & 35 & 0.887 & 0.9 \\
\hline 6 & 35 & 1.357 & 1.1 \\
\hline 6 & 35 & 2.29 & 1.3 \\
\hline 8 & 20 & 9.981 & 3.6 \\
\hline 8 & 20 & 4.295 & 1.9 \\
\hline 8 & 20 & 16.17 & 5.5 \\
\hline 8 & 20 & 8.339 & 3.1 \\
\hline 8 & 25 & 9.619 & 3.5 \\
\hline 8 & 25 & 7.883 & 3.0 \\
\hline 8 & 25 & 16.59 & 5.6 \\
\hline 8 & 25 & 8.486 & 3.2 \\
\hline 8 & 30 & 13.29 & 4.6 \\
\hline 8 & 30 & 6.936 & 2.7 \\
\hline 8 & 30 & 10.85 & 3.9 \\
\hline 8 & 30 & 15.03 & 5.1 \\
\hline 8 & 35 & 4.377 & 2.0 \\
\hline 8 & 35 & 3.352 & 1.7 \\
\hline 8 & 35 & 5.094 & 2.2 \\
\hline 8 & 35 & 8.279 & 3.1 \\
\hline 10 & 20 & 38.2 & 12.1 \\
\hline 10 & 20 & 15.29 & 5.2 \\
\hline 10 & 20 & 50.74 & 15.8 \\
\hline 10 & 20 & 38.96 & 12.3 \\
\hline 10 & 25 & 26.78 & 8.7 \\
\hline 10 & 25 & 32.18 & 10.3 \\
\hline 10 & 25 & 54.53 & 16.9 \\
\hline 10 & 25 & 19.42 & 6.5 \\
\hline 10 & 30 & 39.7 & 12.5 \\
\hline 10 & 30 & 25.26 & 8.2 \\
\hline 10 & 30 & 30.41 & 9.7 \\
\hline 10 & 30 & 51.07 & 15.9 \\
\hline 10 & 35 & 16.54 & 5.6 \\
\hline 10 & 35 & 14.95 & 5.1 \\
\hline 10 & 35 & 20.48 & 6.8 \\
\hline 10 & 35 & 29 & 9.3 \\
\hline
\end{tabular}




\begin{tabular}{|c|c|c|c|}
\hline 13 & 20 & 31.24 & 10.0 \\
\hline 13 & 20 & 46.63 & 14.6 \\
\hline 13 & 20 & 27.5 & 8.9 \\
\hline 13 & 20 & 28.14 & 9.1 \\
\hline 13 & 25 & 55.38 & 17.2 \\
\hline 13 & 25 & 30.48 & 9.8 \\
\hline 13 & 25 & 39.31 & 12.4 \\
\hline 13 & 25 & 58.19 & 18.0 \\
\hline 13 & 30 & 47.2 & 14.8 \\
\hline 13 & 30 & 46.23 & 14.5 \\
\hline 13 & 30 & 47.88 & 15.0 \\
\hline 13 & 30 & 34.53 & 11.0 \\
\hline 13 & 35 & 47.16 & 14.7 \\
\hline 13 & 35 & 70.92 & 21.8 \\
\hline 13 & 35 & 60.59 & 18.7 \\
\hline 13 & 35 & 39.37 & 12.4 \\
\hline 15 & 20 & 31.75 & 10.1 \\
\hline 15 & 20 & 55.61 & 17.3 \\
\hline 15 & 20 & 30.43 & 9.7 \\
\hline 15 & 20 & 23.65 & 7.7 \\
\hline 15 & 25 & 51.29 & 16.0 \\
\hline 15 & 25 & 29.72 & 9.5 \\
\hline 15 & 25 & 45.71 & 14.3 \\
\hline 15 & 25 & 67.65 & 20.9 \\
\hline 15 & 30 & 49.55 & 15.5 \\
\hline 15 & 30 & 36.36 & 11.5 \\
\hline 15 & 30 & 48.21 & 15.1 \\
\hline 15 & 30 & 24.58 & 8.0 \\
\hline 15 & 35 & 46.49 & 14.5 \\
\hline 15 & 35 & 56.43 & 17.5 \\
\hline 15 & 35 & 51.67 & 16.1 \\
\hline 15 & 35 & 43.07 & 13.5 \\
\hline
\end{tabular}


H. Division rate (k) of cultured microalgae at different salinities, 20 25, 30 and $35 \mathrm{psu}$, during logarithmic phase of growth.

\begin{tabular}{|c|c|c|c|}
\hline Strain & Salinity (psu) & Replicate & $\mathrm{k}$ \\
\hline Kb1-2 & 20 & 1 & 1.1 \\
\hline Kb1-2 & & 2 & 1.0 \\
\hline Kb1-2 & & 3 & 1.2 \\
\hline Kb1-2 & & 4 & 1.0 \\
\hline Kb1-2 & 25 & 1 & 0.8 \\
\hline Kb1-2 & & 2 & 0.9 \\
\hline Kb1-2 & & 3 & 0.9 \\
\hline Kb1-2 & & 4 & 0.8 \\
\hline Kb1-2 & 30 & 1 & 0.9 \\
\hline Kb1-2 & & 2 & 0.9 \\
\hline Kb1-2 & & 3 & 0.9 \\
\hline Kb1-2 & & 4 & 1.0 \\
\hline Kb1-2 & 35 & 1 & 0.7 \\
\hline Kb1-2 & & 2 & 0.7 \\
\hline Kb1-2 & & 3 & 0.8 \\
\hline Kb1-2 & & 4 & 0.7 \\
\hline Kb1-3 & 20 & 1 & 0.5 \\
\hline Kb1-3 & & 2 & 1.0 \\
\hline Kb1-3 & & 3 & 1.4 \\
\hline Kb1-3 & & 4 & 1.1 \\
\hline Kb1-3 & 25 & 1 & 0.6 \\
\hline Kb1-3 & & 2 & 0.5 \\
\hline Kb1-3 & & 3 & 1.2 \\
\hline Kb1-3 & & 4 & 1.3 \\
\hline Kb1-3 & 30 & 1 & 1.0 \\
\hline Kb1-3 & & 2 & 0.8 \\
\hline Kb1-3 & & 3 & 1.2 \\
\hline Kb1-3 & & 4 & 1.0 \\
\hline Kb1-3 & 35 & 1 & 1.3 \\
\hline Kb1-3 & & 2 & 1.2 \\
\hline Kb1-3 & & 3 & 1.0 \\
\hline Kb1-3 & & 4 & 1.1 \\
\hline Kb1-5 & 20 & 1 & 1.3 \\
\hline Kb1-5 & & 2 & 1.5 \\
\hline Kb1-5 & & 3 & 1.3 \\
\hline Kb1-5 & & 4 & 1.2 \\
\hline Kb1-5 & 25 & 1 & 1.5 \\
\hline Kb1-5 & & 2 & 1.2 \\
\hline
\end{tabular}




\begin{tabular}{|c|c|c|c|}
\hline Kb1-5 & & 3 & 1.4 \\
\hline Kb1-5 & & 4 & 1.7 \\
\hline Kb1-5 & 30 & 1 & 1.1 \\
\hline Kb1-5 & & 2 & 1.1 \\
\hline Kb1-5 & & 3 & 1.3 \\
\hline Kb1-5 & & 4 & 1.4 \\
\hline Kb1-5 & 35 & 1 & 1.6 \\
\hline Kb1-5 & & 2 & 1.3 \\
\hline Kb1-5 & & 3 & 1.4 \\
\hline Kb1-5 & & 4 & 1.5 \\
\hline C. neogracile & 20 & 1 & 1.1 \\
\hline C. neogracile & & 2 & 1.2 \\
\hline C. neogracile & & 3 & 0.8 \\
\hline C. neogracile & & 4 & 0.9 \\
\hline C. neogracile & 25 & 1 & 0.9 \\
\hline C. neogracile & & 2 & 1.6 \\
\hline C. neogracile & & 3 & 2.5 \\
\hline C. neogracile & & 4 & 1.1 \\
\hline C. neogracile & 30 & 1 & 1.3 \\
\hline C. neogracile & & 2 & 1.1 \\
\hline C. neogracile & & 3 & 0.7 \\
\hline C. neogracile & & 4 & 1.0 \\
\hline C. neogracile & 35 & 1 & 1.0 \\
\hline C. neogracile & & 2 & 1.0 \\
\hline C. neogracile & & 3 & 0.9 \\
\hline C. neogracile & & 4 & 0.9 \\
\hline T. chui & 20 & 1 & 1.0 \\
\hline T. chui & & 2 & 1.0 \\
\hline T. chui & & 3 & 1.3 \\
\hline T. chui & & 4 & 1.3 \\
\hline T. chui & 25 & 1 & 1.6 \\
\hline T. chui & & 2 & 0.9 \\
\hline T. chui & & 3 & 1.4 \\
\hline T. chui & & 4 & 1.3 \\
\hline T. chui & 30 & 1 & 1.5 \\
\hline T. chui & & 2 & 0.9 \\
\hline T. chui & & 3 & 1.3 \\
\hline T. chui & & 4 & 1.4 \\
\hline T. chui & 35 & 1 & 1.1 \\
\hline T. chui & & 2 & 1.2 \\
\hline T. chui & & 3 & 1.3 \\
\hline
\end{tabular}




\begin{tabular}{|l|l|l|l|}
\hline T. chui & & 4 & 1.5 \\
\hline Ti. lutea & 20 & 1 & 0.9 \\
\hline Ti. lutea & & 2 & 0.7 \\
\hline Ti. lutea & & 3 & 0.8 \\
\hline Ti. lutea & & 4 & 1.0 \\
\hline Ti. lutea & 25 & 1 & 0.8 \\
\hline Ti. lutea & & 2 & 0.6 \\
\hline Ti. lutea & & 3 & 0.9 \\
\hline Ti. lutea & & 4 & 0.7 \\
\hline Ti. lutea & 30 & 1 & 0.8 \\
\hline Ti. lutea & & 2 & 0.6 \\
\hline Ti. lutea & & 3 & 0.7 \\
\hline Ti. lutea & & 4 & 0.9 \\
\hline Ti. lutea & 35 & 1 & 0.8 \\
\hline Ti. lutea & & 2 & 0.8 \\
\hline Ti. lutea & & 3 & 0.8 \\
\hline Ti. lutea & & 4 & 0.8 \\
\hline
\end{tabular}


I. Dry weight (DW) and ash free dry weight (AFDW) in $\mu \mathrm{g} \cdot \mathrm{mL}^{-1}$ of Indonesian microalgal strains, C. neogracile, T. Chui and Ti. lutea at different culture salinity

\begin{tabular}{|c|c|c|c|}
\hline Strain & Salinity & DW & AFDW \\
\hline Kb1-2 & 20 & 156 & 124 \\
\hline $\mathrm{Kb} 1-2$ & 20 & 186 & 150 \\
\hline Kb1-2 & 20 & 212 & 152 \\
\hline Kb1-2 & 20 & 146 & 115 \\
\hline Kb1-2 & 25 & 179 & 116 \\
\hline Kb1-2 & 25 & 105 & 87 \\
\hline Kb1-2 & 25 & 67 & 69 \\
\hline Kb1-2 & 25 & 77 & 68 \\
\hline Kb1-2 & 30 & 159 & 123 \\
\hline Kb1-2 & 30 & 189 & 178 \\
\hline Kb1-2 & 30 & 235 & 208 \\
\hline Kb1-2 & 30 & 323 & 228 \\
\hline Kb1-2 & 35 & 207 & 149 \\
\hline Kb1-2 & 35 & 262 & 194 \\
\hline Kb1-2 & 35 & 433 & 298 \\
\hline Kb1-2 & 35 & 231 & 174 \\
\hline Kb1-3 & 20 & 11 & 23 \\
\hline Kb1-3 & 20 & 37 & 45 \\
\hline Kb1-3 & 20 & 16 & 28 \\
\hline Kb1-3 & 20 & 16 & 30 \\
\hline Kb1-3 & 25 & 24 & 25 \\
\hline Kb1-3 & 25 & 44 & 50 \\
\hline Kb1-3 & 25 & 65 & 62 \\
\hline Kb1-3 & 25 & 52 & 53 \\
\hline Kb1-3 & 30 & 26 & 36 \\
\hline Kb1-3 & 30 & 8 & 16 \\
\hline Kb1-3 & 30 & 54 & 51 \\
\hline Kb1-3 & 30 & 35 & 43 \\
\hline Kb1-3 & 35 & 9 & 13 \\
\hline Kb1-3 & 35 & 45 & 62 \\
\hline Kb1-3 & 35 & 26 & 34 \\
\hline Kb1-3 & 35 & 36 & 49 \\
\hline Kb1-5 & 20 & 45 & 9 \\
\hline Kb1-5 & 20 & 101 & -23 \\
\hline Kb1-5 & 20 & 42 & 13 \\
\hline Kb1-5 & 20 & 100 & 8 \\
\hline
\end{tabular}




\begin{tabular}{|l|l|l|l|}
\hline Kb1-5 & 25 & 73 & -6 \\
\hline Kb1-5 & 25 & 9 & 32 \\
\hline Kb1-5 & 25 & 18 & 30 \\
\hline Kb1-5 & 25 & 40 & 72 \\
\hline Kb1-5 & 30 & 153 & -15 \\
\hline Kb1-5 & 30 & 47 & 14 \\
\hline Kb1-5 & 30 & 72 & 9 \\
\hline Kb1-5 & 30 & 59 & 3 \\
\hline Kb1-5 & 35 & 39 & 15 \\
\hline Kb1-5 & 35 & 16 & 29 \\
\hline Kb1-5 & 35 & 15 & 19 \\
\hline Kb1-5 & 35 & 37 & 7 \\
\hline C.neogracile & 20 & 29 & 37 \\
\hline C.neogracile & 20 & 52 & 59 \\
\hline C.neogracile & 20 & 33 & 47 \\
\hline C.neogracile & 20 & 46 & 52 \\
\hline C.neogracile & 25 & 5 & 19 \\
\hline C.neogracile & 25 & 3 & 17 \\
\hline C.neogracile & 25 & 35 & 37 \\
\hline C.neogracile & 25 & 42 & 45 \\
\hline C.neogracile & 30 & 54 & 55 \\
\hline C.neogracile & 30 & 24 & 47 \\
\hline C.neogracile & 30 & 65 & 73 \\
\hline C.neogracile & 30 & 24 & 47 \\
\hline C.neogracile & 35 & 148 & 101 \\
\hline C.neogracile & 35 & 144 & 88 \\
\hline C.neogracile & 35 & 151 & 109 \\
\hline C.neogracile & 35 & 160 & 91 \\
\hline T. chuii & 20 & 137 & 105 \\
\hline T. chuii & 20 & 67 & 79 \\
\hline T. chuii & 20 & 1151 & 1663 \\
\hline T. chuii & 20 & 1206 & 236 \\
\hline T. chuii & 25 & 232 & 192 \\
\hline T. chuii & 25 & 109 & 634 \\
\hline T. chuii & 25 & 1200 & 226 \\
\hline T. chuii & 25 & 114 & 104 \\
\hline T. chuii & 30 & 51 & 60 \\
\hline T. chuii & 30 & 1236 & 248 \\
\hline T. chuii & 30 & 1513 & 182 \\
\hline T. chuii & 30 & 227 & 226 \\
\hline T. chuii & 35 & 67 & 97 \\
\hline & & & \\
\hline & & 57 \\
\hline
\end{tabular}




\begin{tabular}{|l|l|l|l|}
\hline$T$. chuii & 35 & 177 & 181 \\
\hline$T$. chuii & 35 & 127 & 126 \\
\hline$T$. chuii & 35 & 217 & 170 \\
\hline$T$. lutea & 20 & 46 & 43 \\
\hline Ti. lutea & 20 & 45 & 54 \\
\hline Ti. lutea & 20 & 16 & 20 \\
\hline Ti. lutea & 20 & 32 & 49 \\
\hline Ti. lutea & 25 & 7 & 33 \\
\hline Ti. lutea & 25 & 27 & 32 \\
\hline Ti. lutea & 25 & 43 & 37 \\
\hline Ti. lutea & 25 & 7 & 15 \\
\hline Ti. lutea & 30 & 207 & 61 \\
\hline Ti. lutea & 30 & 189 & 49 \\
\hline Ti. lutea & 30 & 217 & 75 \\
\hline Ti. lutea & 30 & 222 & 69 \\
\hline Ti. lutea & 35 & 114 & 114 \\
\hline Ti. lutea & 35 & 164 & 181 \\
\hline Ti. lutea & 35 & 84 & 98 \\
\hline Ti. lutea & 35 & 161 & 170 \\
\hline
\end{tabular}


J. Data of daily survival of shrimp larvae fed on Indonesian microalgal strains, $C$. neogracile, T. lutea and Te. Chui

\begin{tabular}{|c|c|c|c|c|c|}
\hline Day & Strain & Replicate & Day/Time & Dead & Alive \\
\hline 1 & Kb1-2 & 1 & 10:00 AM & 0 & 25 \\
\hline Saturday & Kb1-2 & 2 & Saturday, $8 / 29 / 15$ & 0 & 25 \\
\hline \multirow[t]{18}{*}{$8 / 29 / 2015$} & Kb1-2 & 3 & & 0 & 25 \\
\hline & Kb1-3 & 1 & & 0 & 25 \\
\hline & Kb1-3 & 2 & & 0 & 25 \\
\hline & Kb1-3 & 3 & & 0 & 25 \\
\hline & Kb1-5 & 1 & & 0 & 25 \\
\hline & Kb1-5 & 2 & & 0 & 25 \\
\hline & Kb1-5 & 3 & & 0 & 25 \\
\hline & C. neogracile & 1 & & 0 & 25 \\
\hline & C. neogracile & 2 & & 0 & 25 \\
\hline & C. neogracile & 3 & & 0 & 25 \\
\hline & T. lutea & 1 & & 0 & 25 \\
\hline & T. lutea & 2 & & 0 & 25 \\
\hline & T. lutea & 3 & & 0 & 25 \\
\hline & Te. chui & 1 & & 2 & 25 \\
\hline & Te. chui & 2 & & 0 & 25 \\
\hline & Te. chui & 3 & & 0 & 25 \\
\hline & Control & 1 & & 0 & 25 \\
\hline & Control & 2 & & 0 & 25 \\
\hline 1 & Kb1-2 & 1 & 9:00 PM & & \\
\hline Saturday & Kb1-2 & 2 & Saturday, $8 / 29 / 15$ & & \\
\hline \multirow[t]{16}{*}{$8 / 29 / 2015$} & Kb1-2 & 3 & & & \\
\hline & Kb1-3 & 1 & & & \\
\hline & Kb1-3 & 2 & & & \\
\hline & Kb1-3 & 3 & & & \\
\hline & Kb1-5 & 1 & & & \\
\hline & Kb1-5 & 2 & & & \\
\hline & Kb1-5 & 3 & & & \\
\hline & C. neogracile & 1 & & & \\
\hline & C. neogracile & 2 & & & \\
\hline & C. neogracile & 3 & & & \\
\hline & T. lutea & 1 & & & \\
\hline & T. lutea & 2 & & & \\
\hline & T. lutea & 3 & & & \\
\hline & Te. chui & 1 & & & \\
\hline & Te. chui & 2 & & & \\
\hline & Te. chui & 3 & & & \\
\hline
\end{tabular}




\begin{tabular}{|c|c|c|c|c|c|}
\hline & Control & 1 & & & \\
\hline & Control & 2 & & & \\
\hline 2 & Kb1-2 & 1 & 7:00 AM & 25 & 0 \\
\hline Sunday & Kb1-2 & 2 & Sunday, $8 / 30 / 15$ & 0 & 25 \\
\hline \multirow[t]{18}{*}{$8 / 30 / 2015$} & Kb1-2 & 3 & & 0 & 25 \\
\hline & Kb1-3 & 1 & & 0 & 25 \\
\hline & Kb1-3 & 2 & & 0 & 25 \\
\hline & Kb1-3 & 3 & & 0 & 25 \\
\hline & Kb1-5 & 1 & & 0 & 25 \\
\hline & Kb1-5 & 2 & & 0 & 25 \\
\hline & Kb1-5 & 3 & & 0 & 25 \\
\hline & C. neogracile & 1 & & 0 & 25 \\
\hline & C. neogracile & 2 & & 0 & 25 \\
\hline & C. neogracile & 3 & & 0 & 25 \\
\hline & T. lutea & 1 & & 0 & 25 \\
\hline & T. lutea & 2 & & 0 & 25 \\
\hline & T. lutea & 3 & & 0 & 25 \\
\hline & Te. chui & 1 & & 3 & 22 \\
\hline & Te. chui & 2 & & 0 & 25 \\
\hline & Te. chui & 3 & & 0 & 25 \\
\hline & Control & 1 & & 25 & 4 \\
\hline & Control & 2 & & 20 & 2 \\
\hline 2 & Kb1-2 & 1 & 9:00 PM & & \\
\hline Sunday & Kb1-2 & 2 & Sunday, $8 / 30 / 15$ & & \\
\hline \multirow[t]{17}{*}{$8 / 30 / 2015$} & Kb1-2 & 3 & & & \\
\hline & Kb1-3 & 1 & & & \\
\hline & Kb1-3 & 2 & & & \\
\hline & Kb1-3 & 3 & & & \\
\hline & Kb1-5 & 1 & & & \\
\hline & Kb1-5 & 2 & & & \\
\hline & Kb1-5 & 3 & & & \\
\hline & C. neogracile & 1 & & & \\
\hline & C. neogracile & 2 & & & \\
\hline & C. neogracile & 3 & & & \\
\hline & T. lutea & 1 & & & \\
\hline & T. lutea & 2 & & & \\
\hline & T. lutea & 3 & & & \\
\hline & Te. chui & 1 & & & \\
\hline & Te. chui & 2 & & & \\
\hline & Te. chui & 3 & & & \\
\hline & Control & 1 & & & \\
\hline
\end{tabular}




\begin{tabular}{|c|c|c|c|c|c|}
\hline & Control & 2 & & & \\
\hline 3 & Kb1-2 & 1 & 7:00 AM & 25 & 0 \\
\hline Monday & Kb1-2 & 2 & Monday, 8/31/15 & 22 & 3 \\
\hline \multirow{18}{*}{$8 / 31 / 2015$} & Kb1-2 & 3 & & 23 & 2 \\
\hline & Kb1-3 & 1 & & 18 & 7 \\
\hline & Kb1-3 & 2 & & 13 & 12 \\
\hline & Kb1-3 & 3 & & 19 & 6 \\
\hline & Kb1-5 & 1 & & 19 & 6 \\
\hline & Kb1-5 & 2 & & 20 & 5 \\
\hline & Kb1-5 & 3 & & 19 & 6 \\
\hline & C. neogracile & 1 & & 17 & 8 \\
\hline & C. neogracile & 2 & & 11 & 14 \\
\hline & C. neogracile & 3 & & 19 & 6 \\
\hline & T. lutea & 1 & & 9 & 16 \\
\hline & T. lutea & 2 & & 17 & 8 \\
\hline & T. lutea & 3 & & 17 & 8 \\
\hline & Te. chui & 1 & & 17 & 8 \\
\hline & Te.chui & 2 & & 10 & 15 \\
\hline & Te. chui & 3 & & 22 & 3 \\
\hline & Control & 1 & & 25 & 0 \\
\hline & Control & 2 & & 25 & 0 \\
\hline 3 & Kb1-2 & 1 & 9:00 PM & & \\
\hline Monday & Kb1-2 & 2 & Monday, 8/31/15 & & \\
\hline \multirow[t]{18}{*}{$8 / 31 / 2015$} & Kb1-2 & 3 & & & \\
\hline & Kb1-3 & 1 & & & \\
\hline & Kb1-3 & 2 & & & \\
\hline & Kb1-3 & 3 & & & \\
\hline & Kb1-5 & 1 & & & \\
\hline & Kb1-5 & 2 & & & \\
\hline & Kb1-5 & 3 & & & \\
\hline & C. neogracile & 1 & & & \\
\hline & C. neogracile & 2 & & & \\
\hline & C. neogracile & 3 & & & \\
\hline & T. lutea & 1 & & & \\
\hline & T. lutea & 2 & & & \\
\hline & T. lutea & 3 & & & \\
\hline & Te. chui & 1 & & & \\
\hline & Te. chui & 2 & & & \\
\hline & Te. chui & 3 & & & \\
\hline & Control & 1 & & & \\
\hline & Control & 2 & & & \\
\hline
\end{tabular}




\begin{tabular}{|c|c|c|c|c|c|}
\hline 4 & Kb1-2 & 1 & 7:00 AM & 25 & 0 \\
\hline Tuesday & Kb1-2 & 2 & Tuesday, 09/01/15 & 25 & 0 \\
\hline \multirow[t]{16}{*}{$9 / 1 / 2015$} & Kb1-2 & 3 & & 25 & 0 \\
\hline & Kb1-3 & 1 & & 18 & 7 \\
\hline & Kb1-3 & 2 & & 19 & 6 \\
\hline & Kb1-3 & 3 & & 19 & 6 \\
\hline & Kb1-5 & 1 & & 18 & 7 \\
\hline & Kb1-5 & 2 & & 20 & 5 \\
\hline & Kb1-5 & 3 & & 19 & 6 \\
\hline & C. neogracile & 1 & & 19 & 6 \\
\hline & C. neogracile & 2 & & 8 & 17 \\
\hline & C. neogracile & 3 & & 24 & 1 \\
\hline & T. lutea & 1 & & 10 & 15 \\
\hline & T. lutea & 2 & & 17 & 8 \\
\hline & T. lutea & 3 & & 17 & 8 \\
\hline & Te. chui & 1 & & 18 & 7 \\
\hline & Te. chui & 2 & & 13 & 12 \\
\hline & Te. chui & 3 & & 25 & 0 \\
\hline 4 & Kb1-3 & 1 & 9:00 PM & & \\
\hline Tuesday & $\mathrm{Kb} 1-3$ & 2 & Tuesday, 09/01/15 & & \\
\hline \multirow[t]{13}{*}{ 9/1/2015 } & Kb1-3 & 3 & & & \\
\hline & Kb1-5 & 1 & & & \\
\hline & Kb1-5 & 2 & & & \\
\hline & $\mathrm{Kb} 1-5$ & 3 & & & \\
\hline & C. neogracile & 1 & & & \\
\hline & C. neogracile & 2 & & & \\
\hline & C. neogracile & 3 & & & \\
\hline & T. lutea & 1 & & & \\
\hline & T. lutea & 2 & & & \\
\hline & T. lutea & 3 & & & \\
\hline & Te. chui & 1 & & & \\
\hline & Te. chui & 2 & & & \\
\hline & Te. chui & 3 & & & \\
\hline 5 & Kb1-3 & 1 & 7:00 AM & 20 & 5 \\
\hline Wednesday & Kb1-3 & 2 & $\begin{array}{l}\text { Wednesday, } \\
09 / 02 / 15\end{array}$ & 19 & 6 \\
\hline \multirow[t]{5}{*}{$9 / 2 / 2015$} & $\mathrm{~Kb} 1-3$ & 3 & & 20 & 5 \\
\hline & Kb1-5 & 1 & & 20 & 1 \\
\hline & Kb1-5 & 2 & & 20 & 2 \\
\hline & Kb1-5 & 3 & & 19 & 4 \\
\hline & C. neogracile & 1 & & 19 & 6 \\
\hline
\end{tabular}




\begin{tabular}{|c|c|c|c|c|c|}
\hline & C. neogracile & 2 & & 10 & 14 \\
\hline & C. neogracile & 3 & & 25 & 0 \\
\hline & T. lutea & 1 & & 10 & 15 \\
\hline & T. lutea & 2 & & 18 & 7 \\
\hline & T. lutea & 3 & & 18 & 7 \\
\hline & Te. chui & 1 & & 20 & 5 \\
\hline & Te. chui & 2 & & 13 & 12 \\
\hline & Te. chui & 3 & & 25 & 0 \\
\hline 5 & Kb1-3 & 1 & 9:00 PM & & \\
\hline Wednesday & Kb1-3 & 2 & $\begin{array}{l}\text { Wednesday, } \\
09 / 02 / 15\end{array}$ & & \\
\hline \multirow[t]{13}{*}{$9 / 2 / 2015$} & Kb1-3 & 3 & & & \\
\hline & Kb1-5 & 1 & & & \\
\hline & Kb1-5 & 2 & & & \\
\hline & Kb1-5 & 3 & & & \\
\hline & C. neogracile & 1 & & & \\
\hline & C. neogracile & 2 & & & \\
\hline & C. neogracile & 3 & & & \\
\hline & T. lutea & 1 & & & \\
\hline & T. lutea & 2 & & & \\
\hline & T. lutea & 3 & & & \\
\hline & Te. chui & 1 & & & \\
\hline & Te. chui & 2 & & & \\
\hline & Te. chui & 3 & & & \\
\hline 6 & Kb1-3 & 1 & 7:00 AM & 20 & 5 \\
\hline Thursday & Kb1-3 & 2 & Thursday, 09/03/15 & 23 & 2 \\
\hline \multirow[t]{13}{*}{$9 / 3 / 15$} & Kb1-3 & 3 & & 20 & 5 \\
\hline & Kb1-5 & 1 & & 23 & 2 \\
\hline & Kb1-5 & 2 & & 21 & 4 \\
\hline & Kb1-5 & 3 & & 22 & 3 \\
\hline & C. neogracile & 1 & & 23 & 2 \\
\hline & C. neogracile & 2 & & 16 & 9 \\
\hline & C. neogracile & 3 & & 25 & 0 \\
\hline & T. lutea & 1 & & 10 & 15 \\
\hline & T. lutea & 2 & & 18 & 7 \\
\hline & T. lutea & 3 & & 18 & 7 \\
\hline & T. chui & 1 & & 20 & 5 \\
\hline & T. chui & 2 & & 13 & 12 \\
\hline & T. chui & 3 & & 25 & 0 \\
\hline 6 & Kb1-3 & 1 & 9:00 PM & & \\
\hline Thursday & Kb1-3 & 2 & Thursday, 09/03/15 & & \\
\hline
\end{tabular}




\begin{tabular}{|c|c|c|c|c|c|}
\hline \multirow[t]{13}{*}{$9 / 3 / 2015$} & Kb1-3 & 3 & & & \\
\hline & Kb1-5 & 1 & & & \\
\hline & Kb1-5 & 2 & & & \\
\hline & Kb1-5 & 3 & & & \\
\hline & C. neogracile & 1 & & & \\
\hline & C. neogracile & 2 & & & \\
\hline & C. neogracile & 3 & & & \\
\hline & T. lutea & 1 & & & \\
\hline & T. lutea & 2 & & & \\
\hline & T. lutea & 3 & & & \\
\hline & Te. chui & 1 & & & \\
\hline & Te. chui & 2 & & & \\
\hline & Te. chui & 3 & & & \\
\hline 7 & Kb1-3 & 1 & 7:00 AM & 22 & 3 \\
\hline Friday & Kb1-3 & 2 & Friday, 09/04/15 & 23 & 2 \\
\hline \multirow[t]{13}{*}{$9 / 4 / 2015$} & Kb1-3 & 3 & & 22 & 3 \\
\hline & Kb1-5 & 1 & & 24 & 1 \\
\hline & Kb1-5 & 2 & & 22 & 3 \\
\hline & Kb1-5 & 3 & & 24 & 1 \\
\hline & C. neogracile & 1 & & 24 & 1 \\
\hline & C. neogracile & 2 & & 16 & 9 \\
\hline & C. neogracile & 3 & & 25 & 0 \\
\hline & T. lutea & 1 & & 10 & 15 \\
\hline & T. lutea & 2 & & 22 & 3 \\
\hline & T. lutea & 3 & & 20 & 5 \\
\hline & Te. chui & 1 & & 20 & 5 \\
\hline & Te. chui & 2 & & 15 & 10 \\
\hline & Te. chui & 3 & & 25 & 0 \\
\hline 7 & Kb1-3 & 1 & 9:00 PM & & \\
\hline Friday & Kb1-3 & 2 & Friday, 09/04/15 & & \\
\hline \multirow[t]{11}{*}{ 9/4/2015 } & Kb1-3 & 3 & & & \\
\hline & Kb1-5 & 1 & & & \\
\hline & Kb1-5 & 2 & & & \\
\hline & Kb1-5 & 3 & & & \\
\hline & C. neogracile & 1 & & & \\
\hline & C. neogracile & 2 & & & \\
\hline & C. neogracile & 3 & & & \\
\hline & T. lutea & 1 & & & \\
\hline & T. lutea & 2 & & & \\
\hline & T. lutea & 3 & & & \\
\hline & Te. chui & 1 & & & \\
\hline
\end{tabular}




\begin{tabular}{|l|l|l|l|l|l|}
\hline & Te. chui & 2 & & & \\
\hline & Te. chui & 3 & & & \\
\hline 8 & Kb1-3 & 1 & $7: 00$ AM & 22 & 3 \\
\hline Saturday & Kb1-3 & 2 & Saturday, 09/05/15 & 23 & 2 \\
\hline $9 / 5 / 2015$ & Kb1-3 & 3 & & 22 & 3 \\
\hline & Kb1-5 & 1 & & 24 & 1 \\
\hline & Kb1-5 & 2 & & 22 & 3 \\
\hline & Kb1-5 & 3 & & 24 & 1 \\
\hline & C. neogracile & 1 & & 24 & 1 \\
\hline & C. neogracile & 2 & & 16 & 9 \\
\hline & C. neogracile & 3 & & 25 & 0 \\
\hline & T. lutea & 1 & & 10 & 15 \\
\hline & T. lutea & 2 & & 22 & 3 \\
\hline & T. lutea & 3 & & 20 & 5 \\
\hline & Te. chui & 1 & & 20 & 5 \\
\hline & Te. chui & 2 & & 15 & 10 \\
\hline & Te. chui & 3 & & 25 & 0 \\
\hline
\end{tabular}


E. Growth variables data of individual white shrimp larvae fed Indonesian microalgal strains, C. neogracile, T. lutea and Te. Chui after 8 days of culture except those fed on Kb1-2 and unfed control which was after 4 and 3 days, respectively

\begin{tabular}{|c|c|c|c|c|c|c|c|c|}
\hline Strain & $\begin{array}{l}\text { WG } \\
\text { (ug) }\end{array}$ & FCI & $\begin{array}{l}\text { DW } \\
\text { FI } \\
\text { (ug) }\end{array}$ & SGR & $\begin{array}{l}k 1 \\
(\%)\end{array}$ & FI (\%) & $\begin{array}{l}\text { Increase } \\
\text { WG }(\%)\end{array}$ & $\begin{array}{l}\text { Final } \\
\text { DW } \\
\text { (ug) }\end{array}$ \\
\hline Kb1-2 & 5.7 & 10.8 & 10.4 & 0.15 & 55.1 & 16.74 & 21.4063 & 12.4 \\
\hline Kb1-2 & 3.6 & 17.4 & 9.0 & 0.09 & 39.5 & 14.55 & 11.1111 & 11.6 \\
\hline Kb1-2 & 3.6 & 17.4 & 9.0 & 0.09 & 39.5 & 14.55 & 11.1111 & 11.6 \\
\hline Kb1-2 & 3.6 & 17.4 & 9.0 & 0.09 & 39.5 & 14.55 & 11.1111 & 11.6 \\
\hline Kb1-2 & 8.6 & 7.2 & 30.9 & 0.23 & 27.9 & 50.00 & 36.7898 & 14.5 \\
\hline Kb1-2 & 8.6 & 7.2 & 30.9 & 0.23 & 27.9 & 50.00 & 36.7898 & 14.5 \\
\hline Kb1-3 & 41.5 & 4.4 & 100.9 & 0.25 & 41.1 & 55.41 & 77.7778 & 48.1 \\
\hline Kb1-3 & 41.5 & 4.4 & 100.9 & 0.25 & 41.1 & 55.41 & 77.7778 & 48.1 \\
\hline Kb1-3 & 41.5 & 4.4 & 100.9 & 0.25 & 41.1 & 55.41 & 77.7778 & 48.1 \\
\hline Kb1-3 & 57.0 & 3.2 & 79.6 & 0.26 & 71.6 & 43.69 & 89.0625 & 65.0 \\
\hline Kb1-3 & 57.0 & 3.2 & 79.6 & 0.26 & 71.6 & 43.69 & 89.0625 & 65.0 \\
\hline Kb1-3 & 22.9 & 7.9 & 92.1 & 0.20 & 24.9 & 50.57 & 48.8636 & 28.8 \\
\hline Kb1-3 & 22.9 & 7.9 & 92.1 & 0.20 & 24.9 & 50.57 & 48.8636 & 28.8 \\
\hline Kb1-3 & 22.9 & 7.9 & 92.1 & 0.20 & 24.9 & 50.57 & 48.8636 & 28.8 \\
\hline Kb1-5 & 68.1 & 1.3 & 123.3 & 0.30 & 55.3 & 89.81 & 127.7500 & 74.8 \\
\hline Kb1-5 & 68.9 & 2.0 & 73.3 & 0.28 & 94.0 & 53.36 & 107.6042 & 76.9 \\
\hline Kb1-5 & 68.9 & 2.0 & 73.3 & 0.28 & 94.0 & 53.36 & 107.6042 & 76.9 \\
\hline Kb1-5 & 68.9 & 2.0 & 73.3 & 0.28 & 94.0 & 53.36 & 107.6042 & 76.9 \\
\hline Kb1-5 & 42.7 & 3.2 & 75.2 & 0.26 & 56.9 & 54.76 & 91.0511 & 48.6 \\
\hline C. neogracile & 78.6 & 3.4 & 144.1 & 0.32 & 54.6 & 53.15 & 147.4375 & 85.3 \\
\hline C. neogracile & 38.8 & 7.0 & 142.7 & 0.22 & 27.2 & 52.67 & 60.5903 & 46.8 \\
\hline C. neogracile & 38.8 & 7.0 & 142.7 & 0.22 & 27.2 & 52.67 & 60.5903 & 46.8 \\
\hline C. neogracile & 38.8 & 7.0 & 142.7 & 0.22 & 27.2 & 52.67 & 60.5903 & 46.8 \\
\hline C. neogracile & 38.8 & 7.0 & 142.7 & 0.22 & 27.2 & 52.67 & 60.5903 & 46.8 \\
\hline C. neogracile & 38.8 & 7.0 & 142.7 & 0.22 & 27.2 & 52.67 & 60.5903 & 46.8 \\
\hline C. neogracile & 38.8 & 7.0 & 142.7 & 0.22 & 27.2 & 52.67 & 60.5903 & 46.8 \\
\hline C. neogracile & 38.8 & 7.0 & 142.7 & 0.22 & 27.2 & 52.67 & 60.5903 & 46.8 \\
\hline C. neogracile & 38.8 & 7.0 & 142.7 & 0.22 & 27.2 & 52.67 & 60.5903 & 46.8 \\
\hline C. neogracile & 38.8 & 7.0 & 142.7 & 0.22 & 27.2 & 52.67 & 60.5903 & 46.8 \\
\hline T. lutea & 7.6 & 25.1 & 98.0 & 0.10 & 7.8 & 51.08 & 14.3250 & 14.3 \\
\hline T. lutea & 7.6 & 25.1 & 98.0 & 0.10 & 7.8 & 51.08 & 14.3250 & 14.3 \\
\hline T. lutea & 7.6 & 25.1 & 98.0 & 0.10 & 7.8 & 51.08 & 14.3250 & 14.3 \\
\hline T. lutea & 7.6 & 25.1 & 98.0 & 0.10 & 7.8 & 51.08 & 14.3250 & 14.3 \\
\hline T. lutea & 7.6 & 25.1 & 98.0 & 0.10 & 7.8 & 51.08 & 14.3250 & 14.3 \\
\hline T. lutea & 7.6 & 25.1 & 98.0 & 0.10 & 7.8 & 51.08 & 14.3250 & 14.3 \\
\hline
\end{tabular}




\begin{tabular}{|c|c|c|c|c|c|c|c|c|}
\hline T. lutea & 7.6 & 25.1 & 98.0 & 0.10 & 7.8 & 51.08 & 14.3250 & 14.3 \\
\hline T. lutea & 7.6 & 25.1 & 98.0 & 0.10 & 7.8 & 51.08 & 14.3250 & 14.3 \\
\hline T. lutea & 7.6 & 25.1 & 98.0 & 0.10 & 7.8 & 51.08 & 14.3250 & 14.3 \\
\hline T. lutea & 7.6 & 25.1 & 98.0 & 0.10 & 7.8 & 51.08 & 14.3250 & 14.3 \\
\hline T. lutea & 7.6 & 25.1 & 98.0 & 0.10 & 7.8 & $\begin{array}{l}51.08 \\
\end{array}$ & 14.3250 & 14.3 \\
\hline T. lutea & 7.6 & 25.1 & 98.0 & 0.10 & 7.8 & 51.08 & 14.3250 & 14.3 \\
\hline T. lutea & 7.6 & 25.1 & 98.0 & 0.10 & 7.8 & 51.08 & 14.3250 & 14.3 \\
\hline T. lutea & 7.6 & 25.1 & 98.0 & 0.10 & 7.8 & 51.08 & 14.3250 & 14.3 \\
\hline T. lutea & 7.6 & 25.1 & 98.0 & 0.10 & 7.8 & 51.08 & 14.3250 & 14.3 \\
\hline T. lutea & 61.3 & 3.1 & 93.4 & 0.27 & 65.6 & 48.69 & 95.7292 & 69.3 \\
\hline T. lutea & 61.3 & 3.1 & 93.4 & 0.27 & 65.6 & 48.69 & 95.7292 & 69.3 \\
\hline T. lutea & 61.3 & 3.1 & 93.4 & 0.27 & 65.6 & 48.69 & 95.7292 & 69.3 \\
\hline T. lutea & 37.7 & 5.1 & 99.7 & 0.25 & 37.9 & 51.96 & 80.3977 & 43.6 \\
\hline T. lutea & 37.7 & 5.1 & 99.7 & 0.25 & 37.9 & 51.96 & 80.3977 & 43.6 \\
\hline T. lutea & 37.7 & 5.1 & 99.7 & 0.25 & 37.9 & 51.96 & 80.3977 & 43.6 \\
\hline T. lutea & 37.7 & 5.1 & 99.7 & 0.25 & 37.9 & 51.96 & 80.3977 & 43.6 \\
\hline T. lutea & 37.7 & 5.1 & 99.7 & 0.25 & 37.9 & 51.96 & 80.3977 & 43.6 \\
\hline T. chui & 38.5 & 21.5 & 531.6 & 0.24 & 7.2 & 64.13 & 72.2500 & 45.2 \\
\hline T. chui & 38.5 & 21.5 & 531.6 & 0.24 & 7.2 & 64.13 & 72.2500 & 45.2 \\
\hline T. chui & 38.5 & 21.5 & 531.6 & 0.24 & 7.2 & 64.13 & 72.2500 & 45.2 \\
\hline T. chui & 38.5 & 21.5 & 531.6 & 0.24 & 7.2 & 64.13 & 72.2500 & 45.2 \\
\hline T. chui & 38.5 & 21.5 & 531.6 & 0.24 & 7.2 & 64.13 & 72.2500 & 45.2 \\
\hline T. chui & 12.0 & 69.0 & 504.7 & 0.11 & 2.4 & 60.88 & 18.7812 & 20.0 \\
\hline T. chui & 12.0 & 69.0 & 504.7 & 0.11 & 2.4 & 60.88 & 18.7812 & 20.0 \\
\hline T. chui & 12.0 & 69.0 & 504.7 & 0.11 & 2.4 & 60.88 & 18.7812 & 20.0 \\
\hline T. chui & 12.0 & 69.0 & 504.7 & 0.11 & 2.4 & 60.88 & 18.7812 & 20.0 \\
\hline T. chui & 12.0 & 69.0 & 504.7 & 0.11 & 2.4 & 60.88 & 18.7812 & 20.0 \\
\hline T. chui & 12.0 & 69.0 & 504.7 & 0.11 & 2.4 & 60.88 & 18.7812 & 20.0 \\
\hline T. chui & 12.0 & 69.0 & 504.7 & 0.11 & 2.4 & 60.88 & 18.7812 & 20.0 \\
\hline T. chui & 12.0 & 69.0 & 504.7 & 0.11 & 2.4 & 60.88 & 18.7812 & 20.0 \\
\hline T. chui & 12.0 & 69.0 & 504.7 & 0.11 & 2.4 & 60.88 & 18.7812 & 20.0 \\
\hline T. chui & 12.0 & 69.0 & 504.7 & 0.11 & 2.4 & 60.88 & 18.7812 & 20.0 \\
\hline Unfed control & 0.3 & 0.0 & 0.0 & 0.01 & 0.0 & 0.00 & 0.6250 & 7.0 \\
\hline Unfed control & 0.3 & 0.0 & 0.0 & 0.01 & 0.0 & 0.00 & 0.6250 & 7.0 \\
\hline Unfed control & 0.3 & 0.0 & 0.0 & 0.01 & 0.0 & 0.00 & 0.6250 & 7.0 \\
\hline Unfed control & 0.3 & 0.0 & 0.0 & 0.01 & 0.0 & 0.00 & 0.6250 & 7.0 \\
\hline Unfed control & 1.4 & 0.0 & 0 & 0.03 & 0.0 & 0.00 & 2.8883 & 7.2 \\
\hline Unfed control & 1.4 & 0.0 & 0 & 0.03 & 0.0 & 0.00 & 2.8883 & 7.2 \\
\hline
\end{tabular}


F. Chromatogram of Fatty Acids from FAME STD (Supelco 37 Component FAME mix Sigma Aldrich USA) by GC/MS Method Agilent 6890 GC with 5973 MSD

Abundance

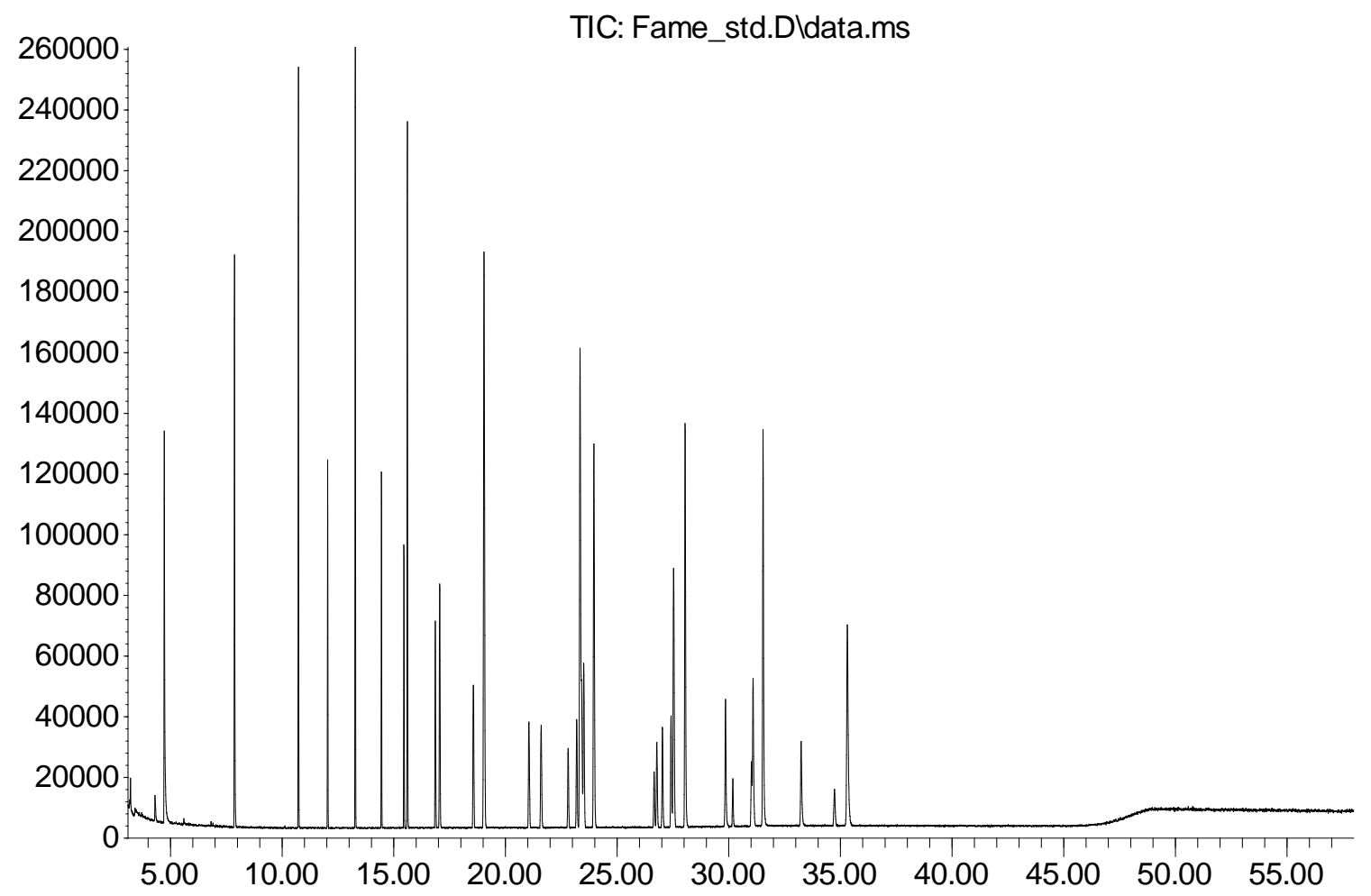

Time--> 
G. Fatty Acids from FAME STD (Supelco 37 Component FAME mix Sigma Aldrich USA) identified by GC/MS Method Agilent 6890 GC with 5973 MSD

\begin{tabular}{|c|c|c|c|c|c|c|}
\hline No & Systemic Name & Common Name & Formula & $\begin{array}{l}\text { Length : } \\
{ }^{\circ} \text { unsaturation }\end{array}$ & $\begin{array}{l}\text { Molecular } \\
\text { Weight } \\
\text { (Da) }\end{array}$ & $\begin{array}{l}\text { Retention } \\
\text { Time (min) }\end{array}$ \\
\hline 1 & Hexanoic acid & Caproic acid & C7H14O2 & $6 ; 0$ & 130 & 4.727 \\
\hline 2 & Octanoic acid & Caprylic acid & C9H18O2 & $8 ; 0$ & 158 & 7.869 \\
\hline 3 & Decanoic acid & Capric acid & $\mathrm{C} 11 \mathrm{H} 22 \mathrm{O} 2$ & $10 ; 0$ & 186 & 10.732 \\
\hline 4 & Undecanoic acid & Undecyclic acid & $\mathrm{C} 12 \mathrm{H} 24 \mathrm{O} 2$ & $11 ; 0$ & 200 & 12.041 \\
\hline 5 & Dodecanoic acid & Lauric Acid & $\mathrm{C} 13 \mathrm{H} 26 \mathrm{O} 2$ & $12 ; 0$ & 214 & 13.279 \\
\hline 6 & Tridecanoic acid & Tridecyclic acid & $\mathrm{C} 14 \mathrm{H} 28 \mathrm{O} 2$ & $13 ; 0$ & 228 & 14.450 \\
\hline 7 & Myristic Acid & Tetradecanoic acid & $\mathrm{C} 15 \mathrm{H} 30 \mathrm{O} 2$ & $14 ; 0$ & 242 & 15.609 \\
\hline 8 & Pentadecanoic acid & Pentadecyclic acid & $\mathrm{C} 16 \mathrm{H} 32 \mathrm{O} 2$ & $15 ; 0$ & 256 & 17.061 \\
\hline 9 & 9-hexadecanoic acid & Palmitoleic acid & $\mathrm{C} 17 \mathrm{H} 32 \mathrm{O} 2$ & $16: 1(n-7)$ & 268 & 18.567 \\
\hline 10 & Hexadecanoic acid & Palmitic acid & $\mathrm{C} 17 \mathrm{H} 34 \mathrm{O} 2$ & $16 ; 0$ & 270 & 19.046 \\
\hline 11 & Heptadecanoic acid & Margaric acid & $\mathrm{C} 18 \mathrm{H} 36 \mathrm{O} 2$ & $17 ; 0$ & 284 & 21.601 \\
\hline 12 & 9,12-octadecadienic acid & Linoleic acid & $\mathrm{C} 19 \mathrm{H} 34 \mathrm{O} 2$ & $18: 2(n-6)$ & 294 & 23.195 \\
\hline 13 & 9-octadecanoic acid & Oleic acid & $\mathrm{C} 19 \mathrm{H} 36 \mathrm{O} 2$ & $18: 1(n-9)$ & 296 & 23.343 \\
\hline 14 & trans-9-Octadecenoic acid & Elaidic acid & $\mathrm{C} 19 \mathrm{H} 36 \mathrm{O} 2$ & t18:1(n-9) & 296 & 23.510 \\
\hline 15 & Octadecanoic acid & Stearic acid & $\mathrm{C} 19 \mathrm{H} 38 \mathrm{O} 2$ & $18 ; 0$ & 298 & 23.963 \\
\hline 16 & $5,8,11,14$ eicosatrienoic acid & $\begin{array}{l}\text { Arachidonic acid } \\
\text { (ARA) }\end{array}$ & $\mathrm{C} 21 \mathrm{H} 36 \mathrm{O} 2$ & $20: 4(n-6)$ & 320 & 27.032 \\
\hline 17 & 11,14 eicosadienoic acid & Dihomolinoleic acid & $\mathrm{C} 31 \mathrm{H} 38 \mathrm{O} 2$ & $20: 2(n-6)$ & 322 & 27.419 \\
\hline 18 & 11-Eicosanoic acid & Gondoic acid & $\mathrm{C} 21 \mathrm{H} 40 \mathrm{O} 2$ & $20: 1(n-9)$ & 324 & 27.532 \\
\hline 19 & 9,12,15-Octadecatrienoic Acid & $\alpha$-Linolenic Acid & $\mathrm{C} 19 \mathrm{H} 32 \mathrm{O} 2$ & $18: 3(n-3)$ & 292 & 27.550 \\
\hline 20 & Eicosanoic acid & Arachidic acid & $\mathrm{C} 21 \mathrm{H} 42 \mathrm{O} 2$ & $20 ; 0$ & 326 & 28.049 \\
\hline 21 & Heneicosanoic acid & Heneicosylic Acid & $\mathrm{C} 22 \mathrm{H} 42 \mathrm{O} 2$ & $21 ; 0$ & 340 & 29.856 \\
\hline
\end{tabular}




\begin{tabular}{|l|l|l|l|l|l|l|}
\hline 22 & $\begin{array}{l}4,7,10.13 .16,19- \\
\text { Docosahexaenoic Acid }\end{array}$ & Cervonic acid (DHA) & C23H34O2 & $22: 6(\mathrm{n}-3)$ & 342 & 30.168 \\
\hline 23 & Docosanoic acid & Behenic acid & C23H46O2 & $22 ; 0$ & 354 & 31.538 \\
\hline 24 & Tricosanoic acid & Tricosylic acid & C24H48O2 & $24: 1(\mathrm{n}-9)$ & 368 & 33.243 \\
\hline 25 & $15-$ Tetracosanoic acid & Nervonic acid & C25H48O2 & $24: 1(\mathrm{n}-9)$ & 380 & 34.736 \\
\hline 26 & Tetracosanoic acid & Lignoceric Acid & C25H50O2 & $24 ; 0$ & 382 & 35.313 \\
\hline
\end{tabular}


H. Chromatogram of Fatty Acids from T. lutea samples by GC/MS Method Agilent 6890 GC with 5973 MSD at 20 (a), 25 (b), 30 (c) and 35 (d) psu

Abundance

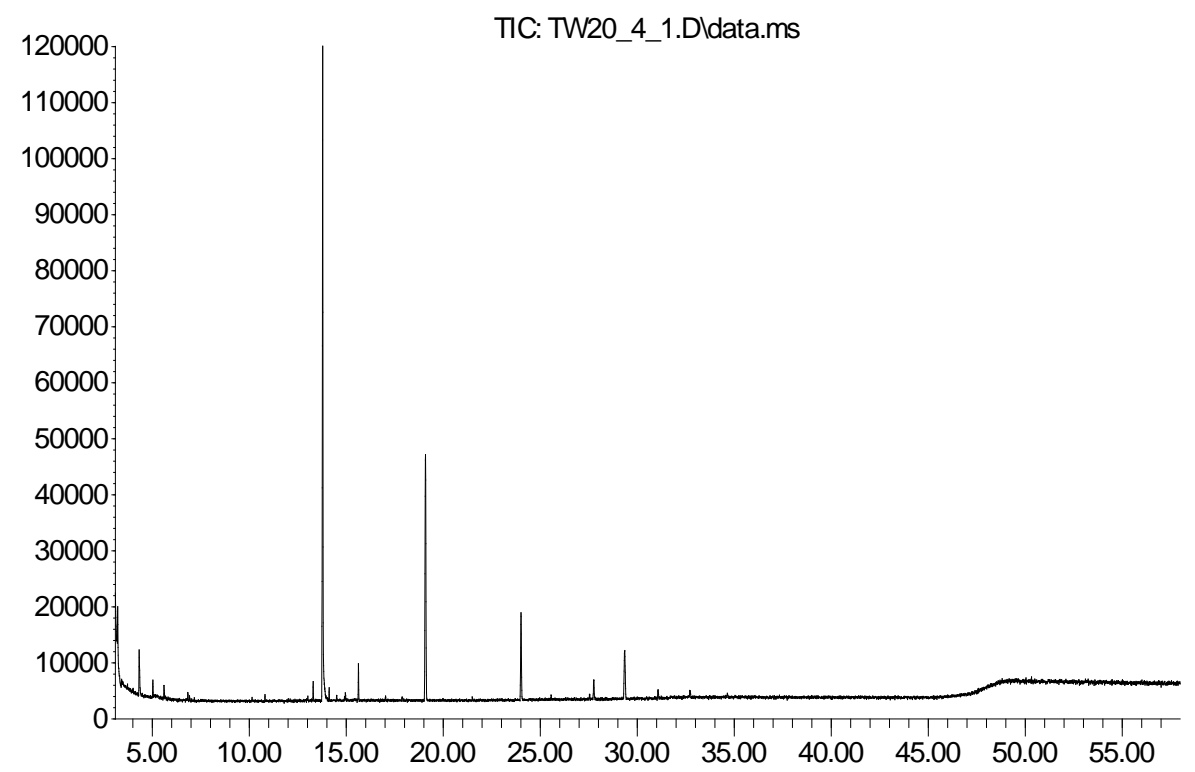

Time-->

Abundance

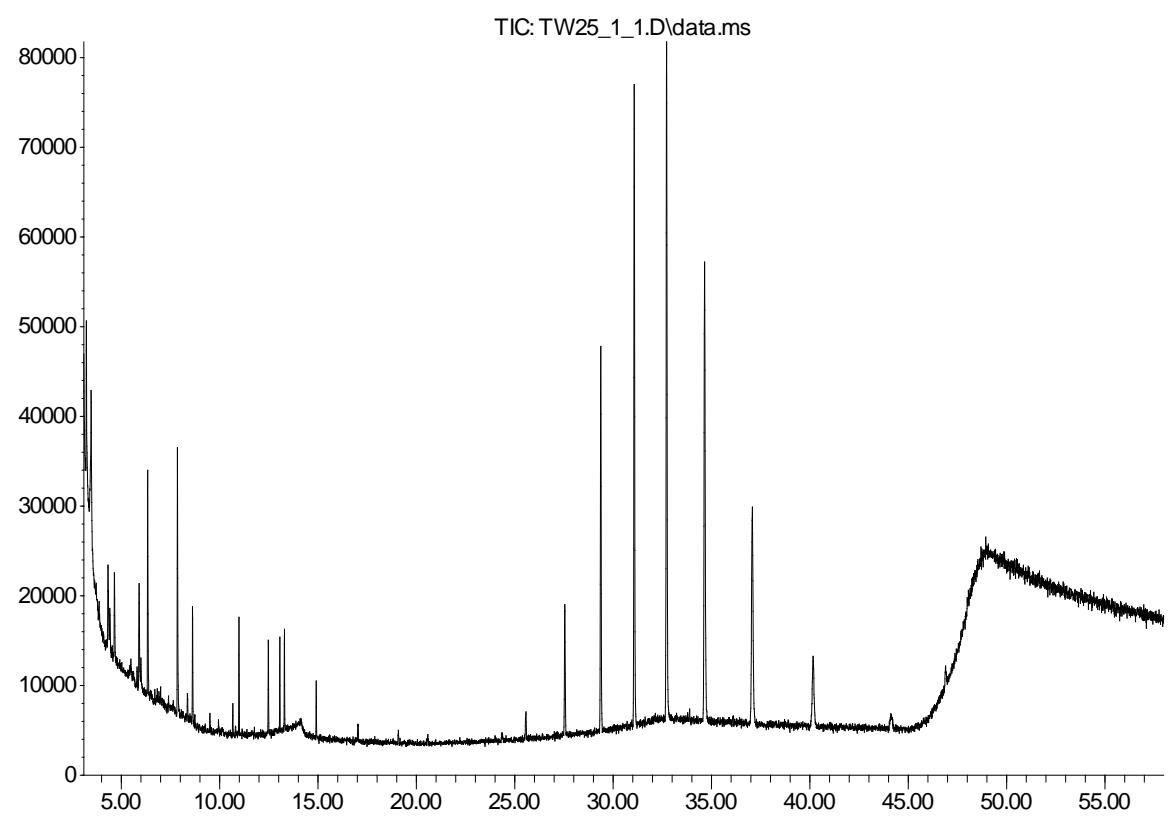

Time--> 
Abundance

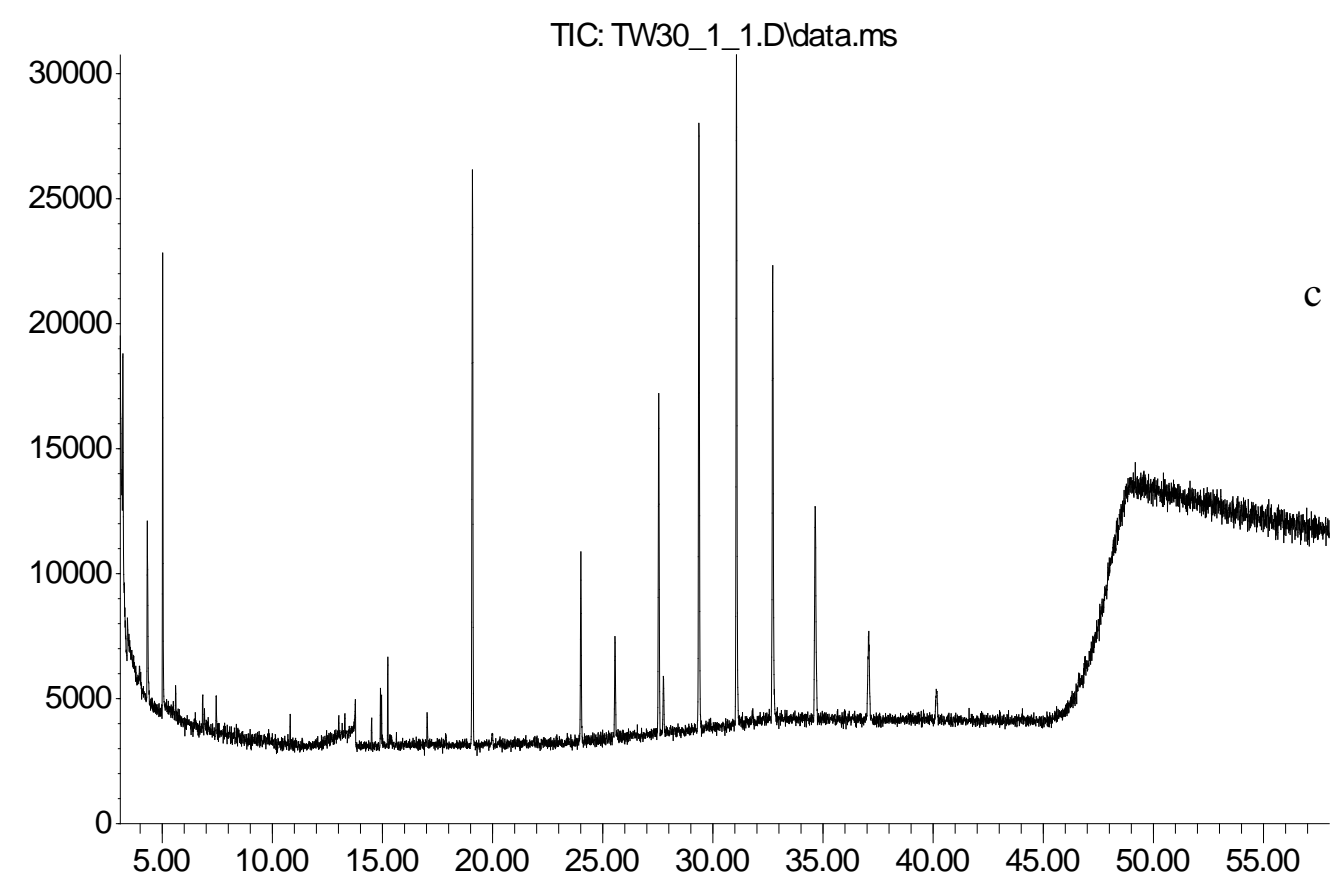

Time-->

Abundance

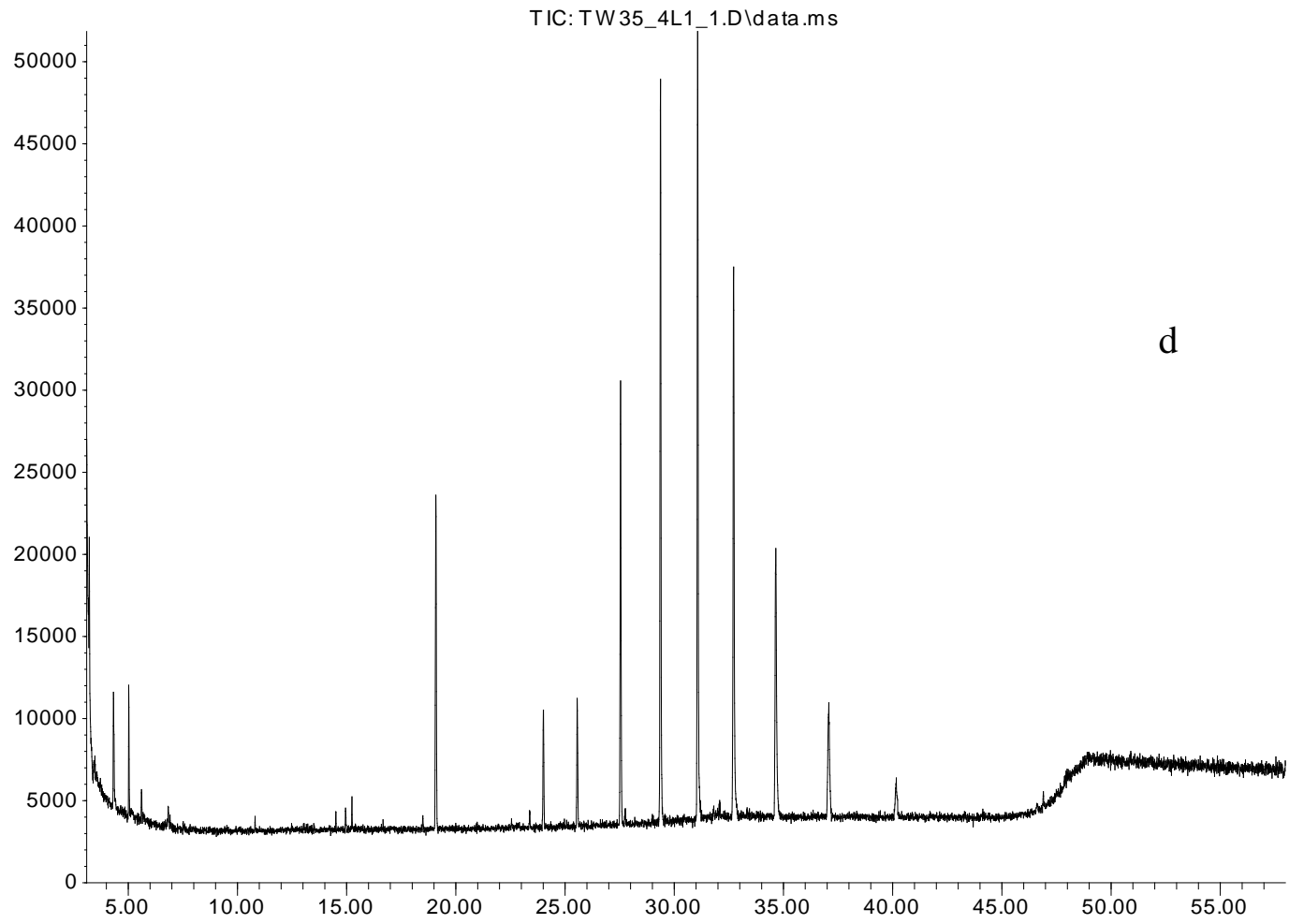

Time--> 
I. Chromatogram of Fatty Acids from Chaetoceros sp. samples by GC/MS Method Agilent 6890 GC with 5973 MSD at 20 (a), 25 (b), 30 (c) and 35 (d) psu

Abundance

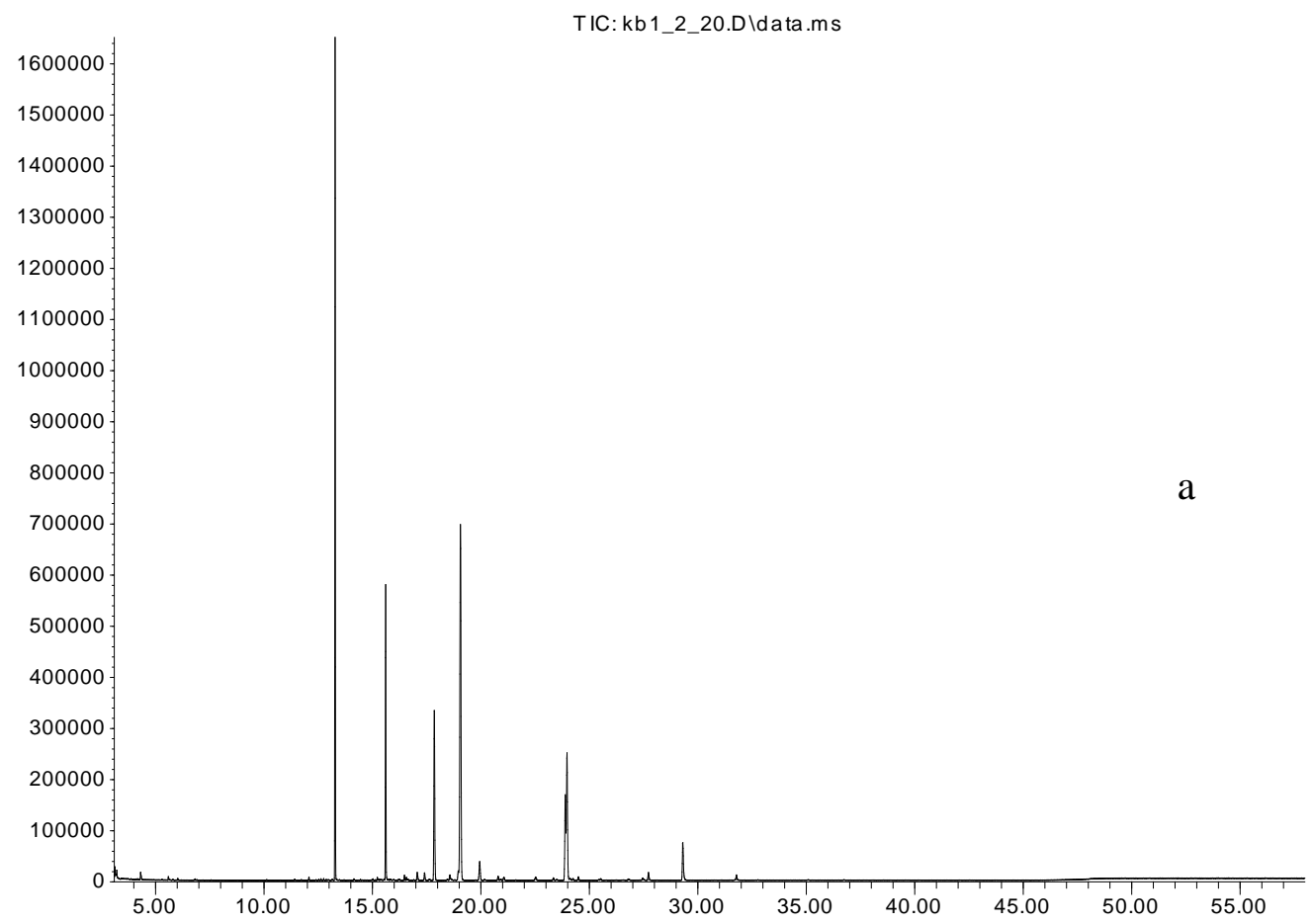

Time-->

Abundance

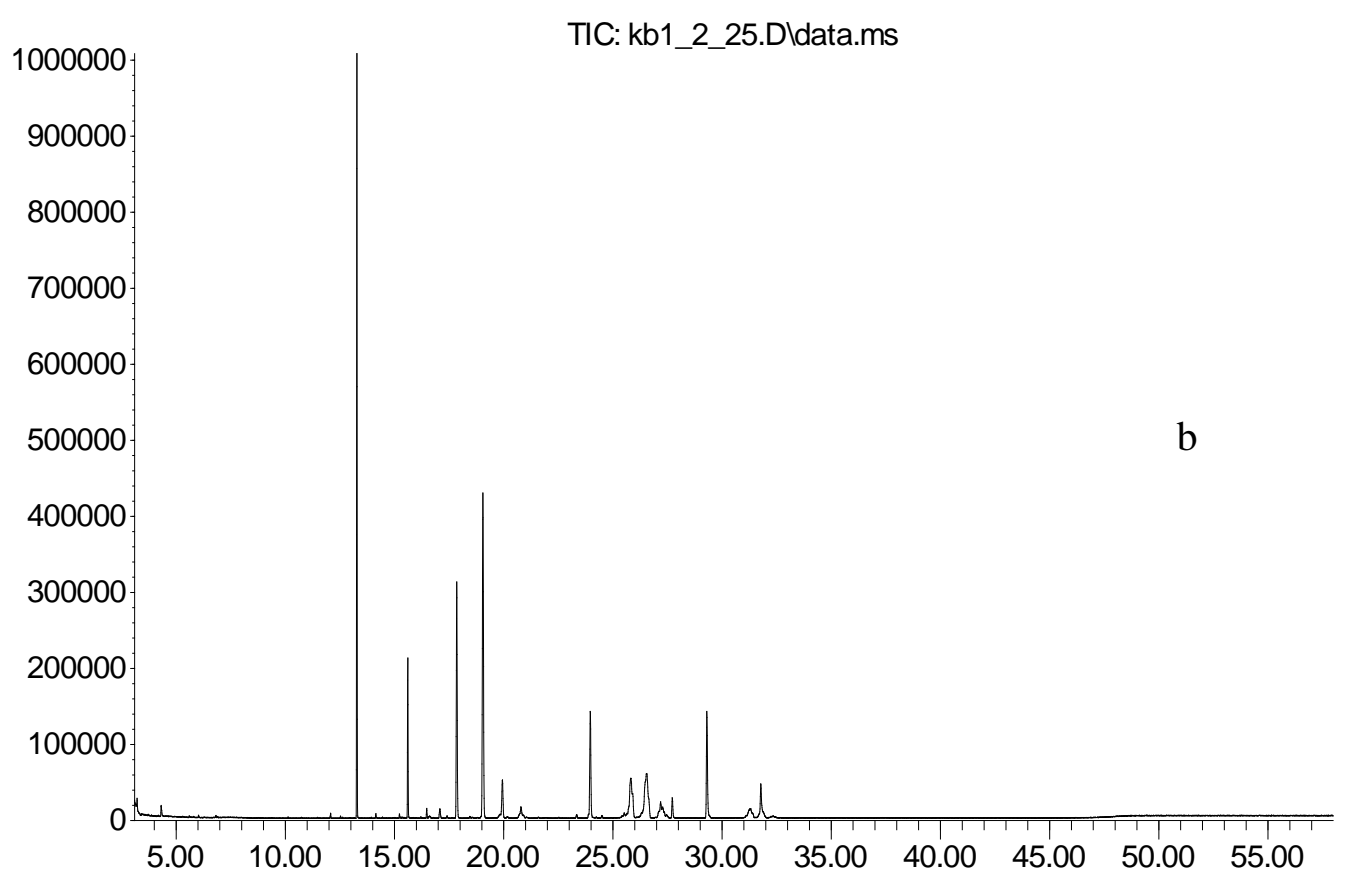

Time--> 
Abundance

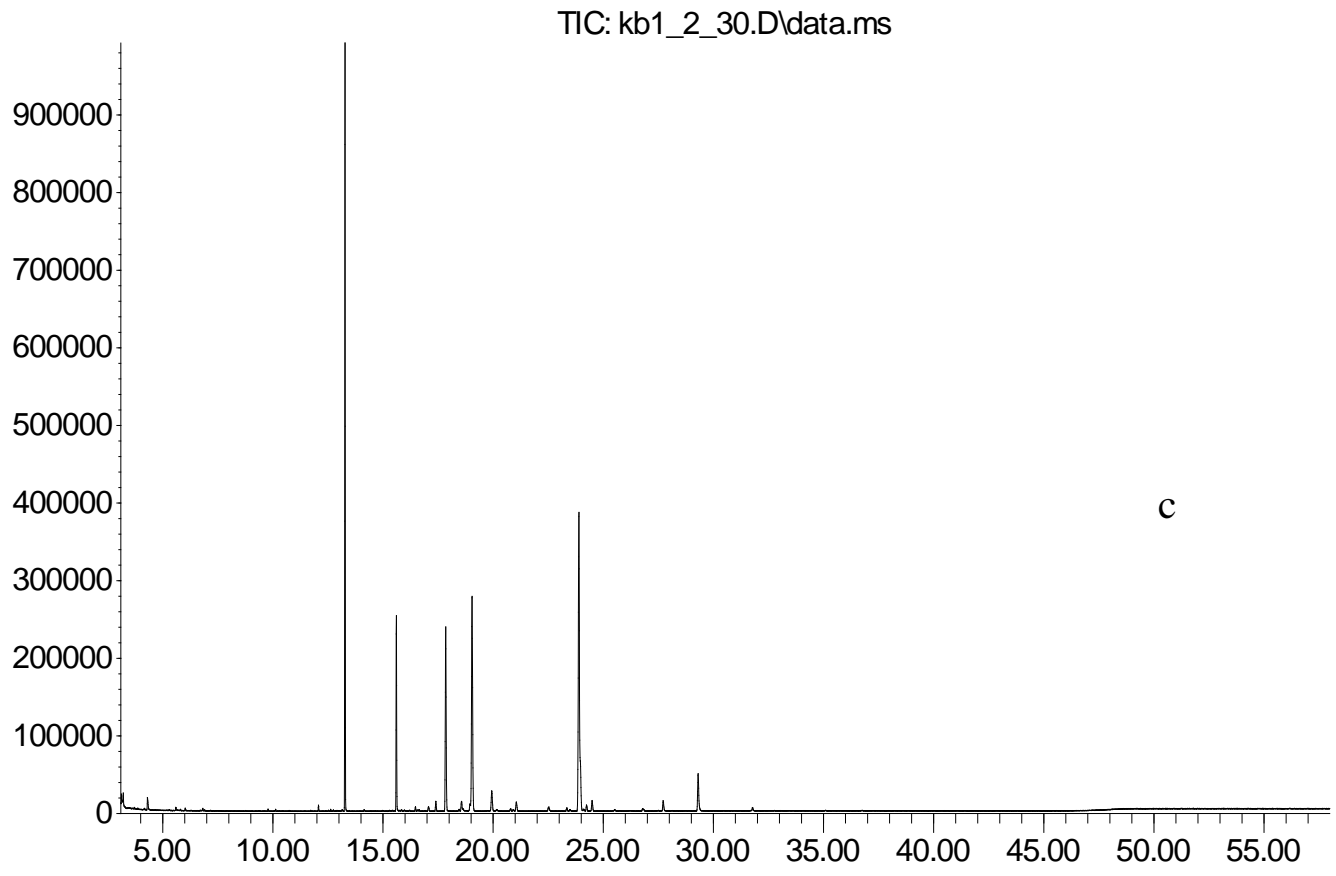

Time-->

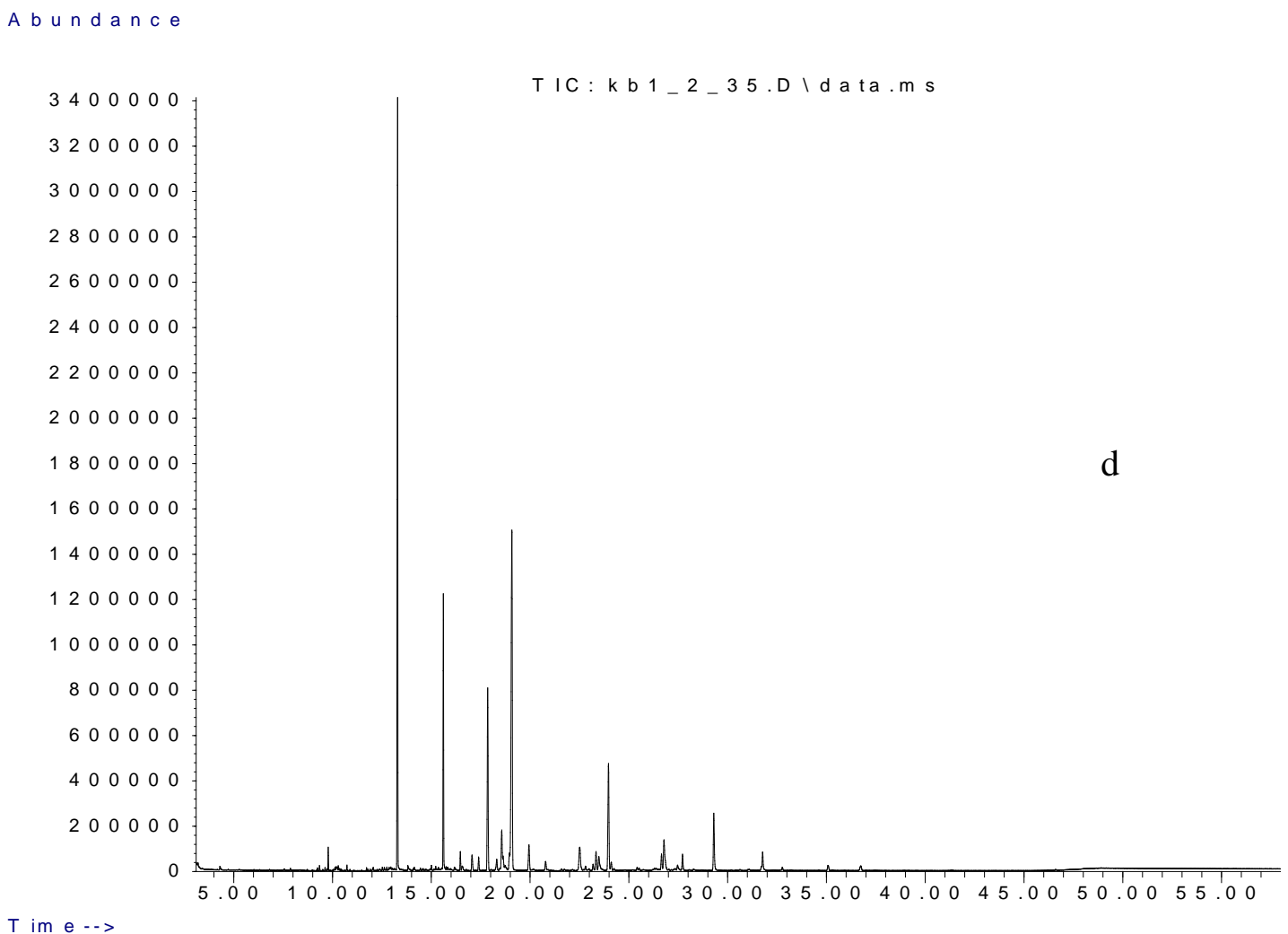


J. Chromatogram of Fatty Acids from Kb1-3 samples by GC/MS Method Agilent Abund $6890 \mathrm{GC}$ with $5973 \mathrm{MSD}$ at 20 (a), 25 (b), 30 (c) and 35 (d) psu

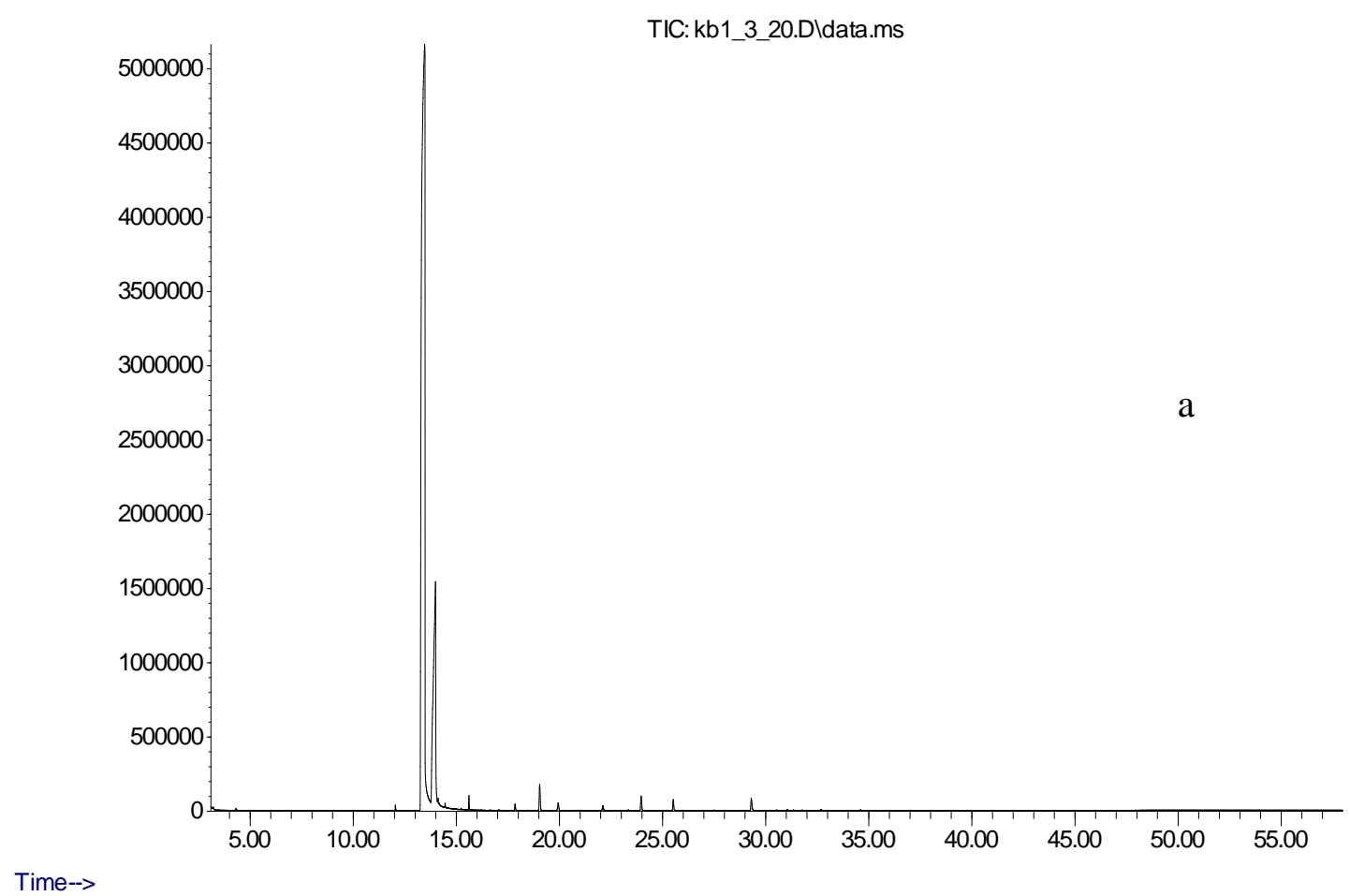

Abundance

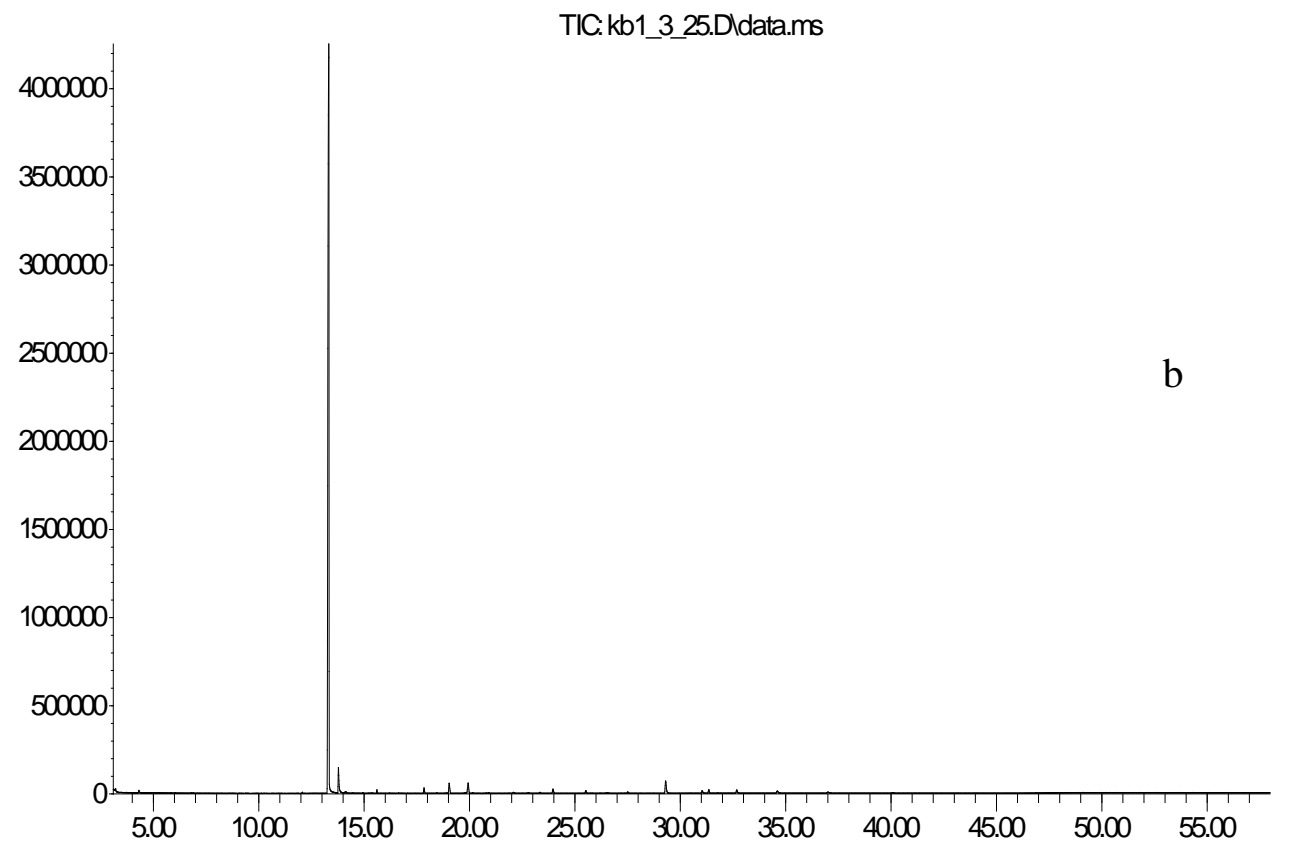


Abundance

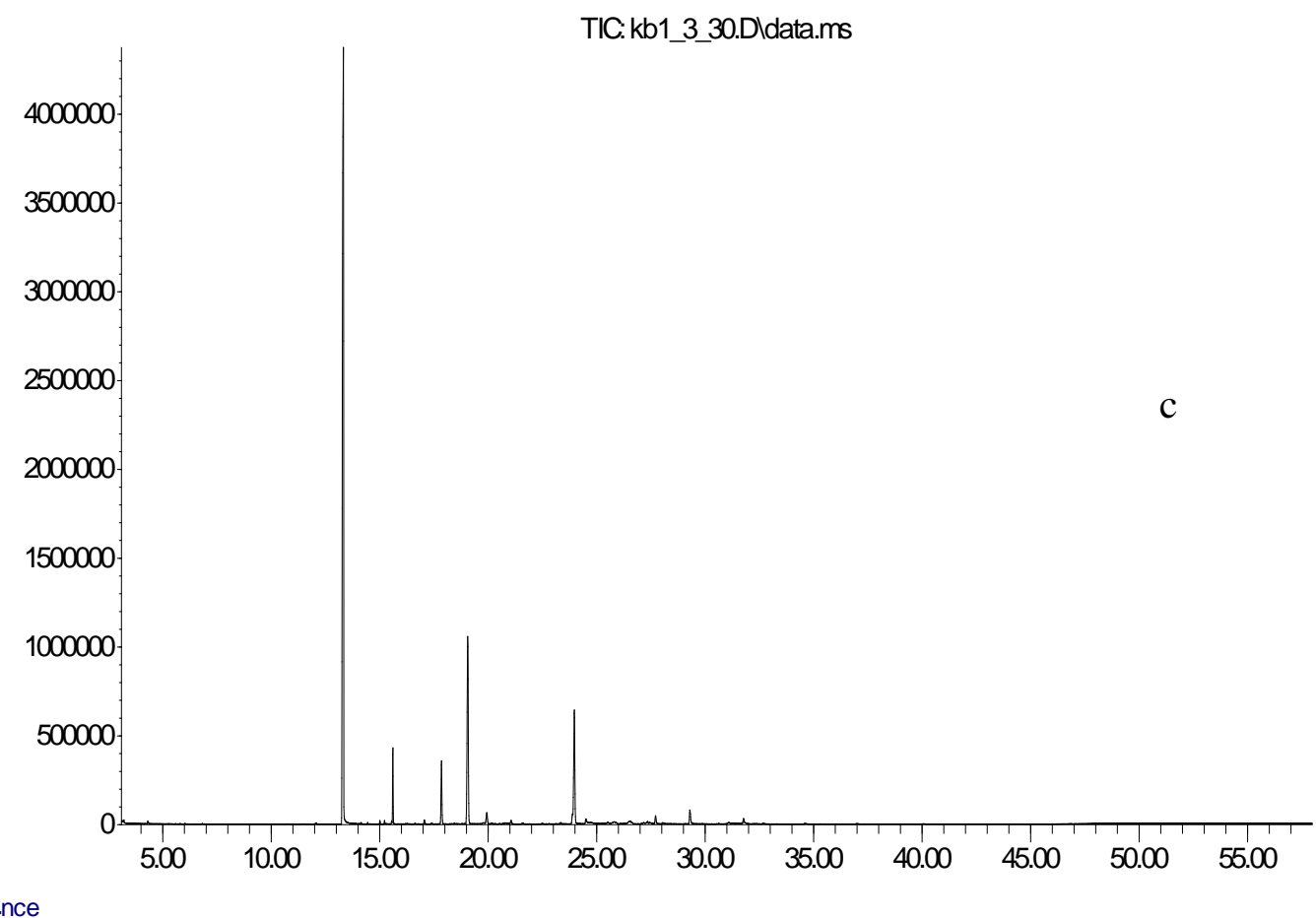

Time-->nce

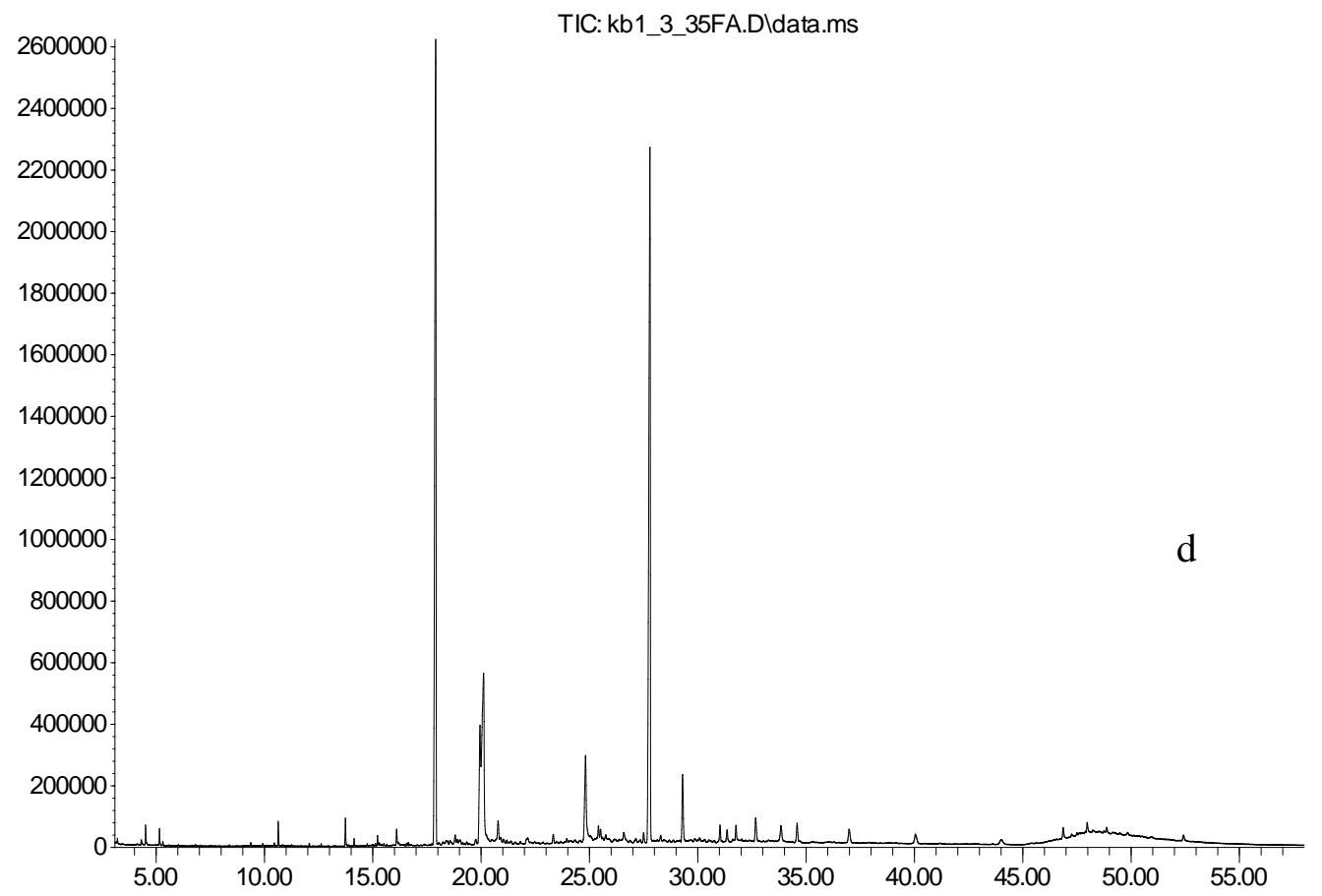

Time--> 
K. Chromatogram of Fatty Acids from Kb1-5 samples by GC/MS Method Agilent 6890 GC with 5973 MSD at 20 (a), 25 (b), 30 (c) and 35 (d) psu

Abundance

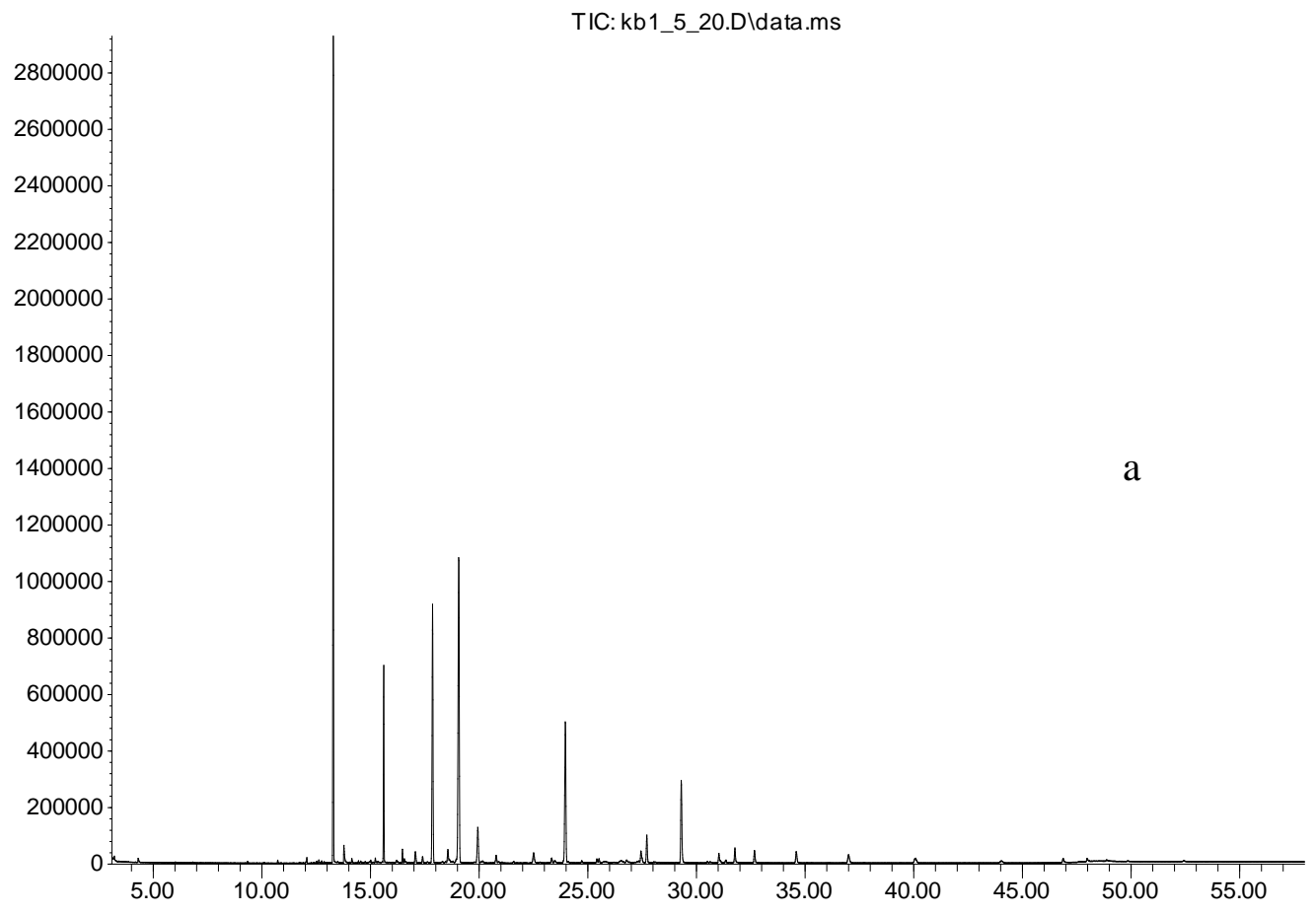

Time-->

Abundance

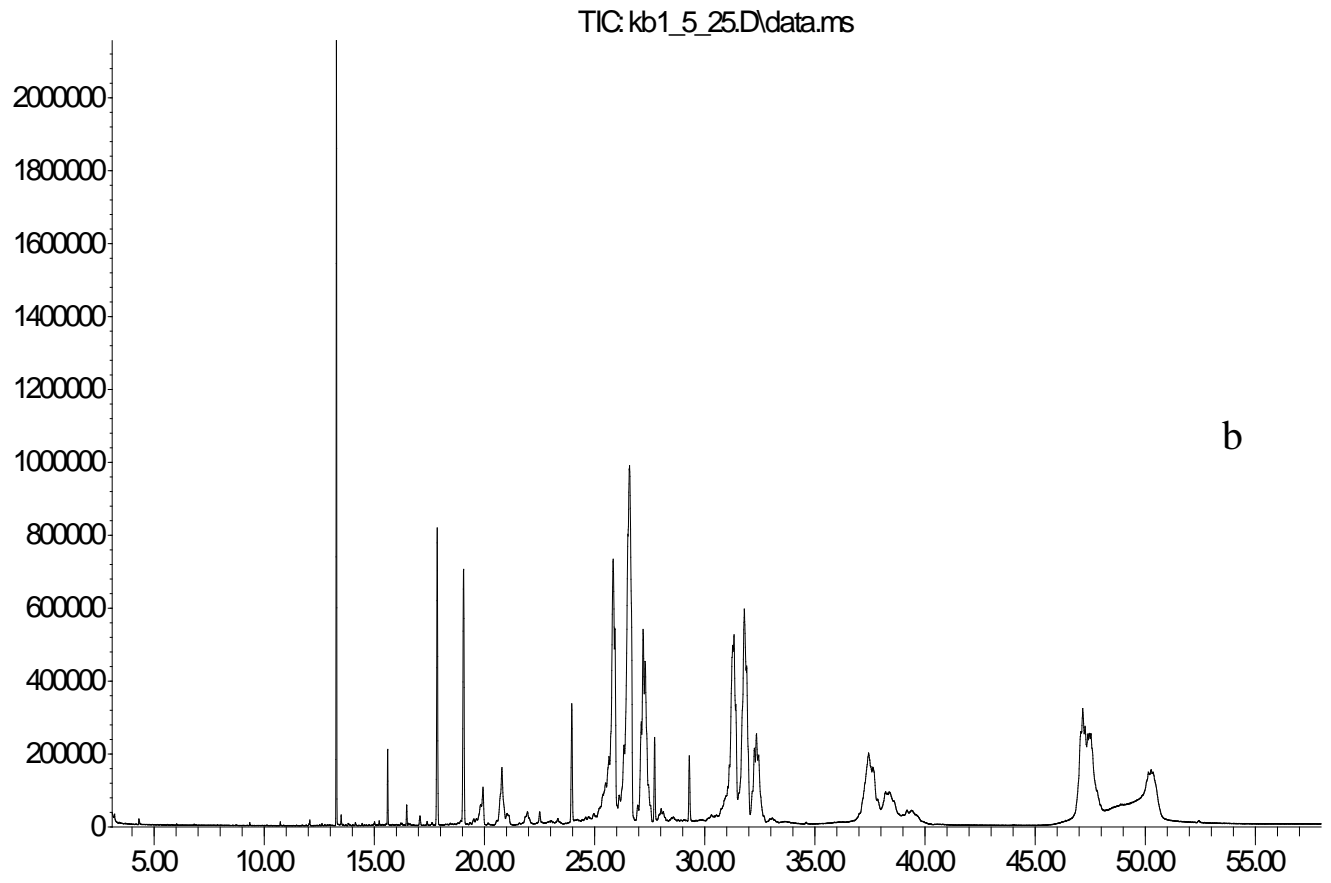

Time-> 
Abundance

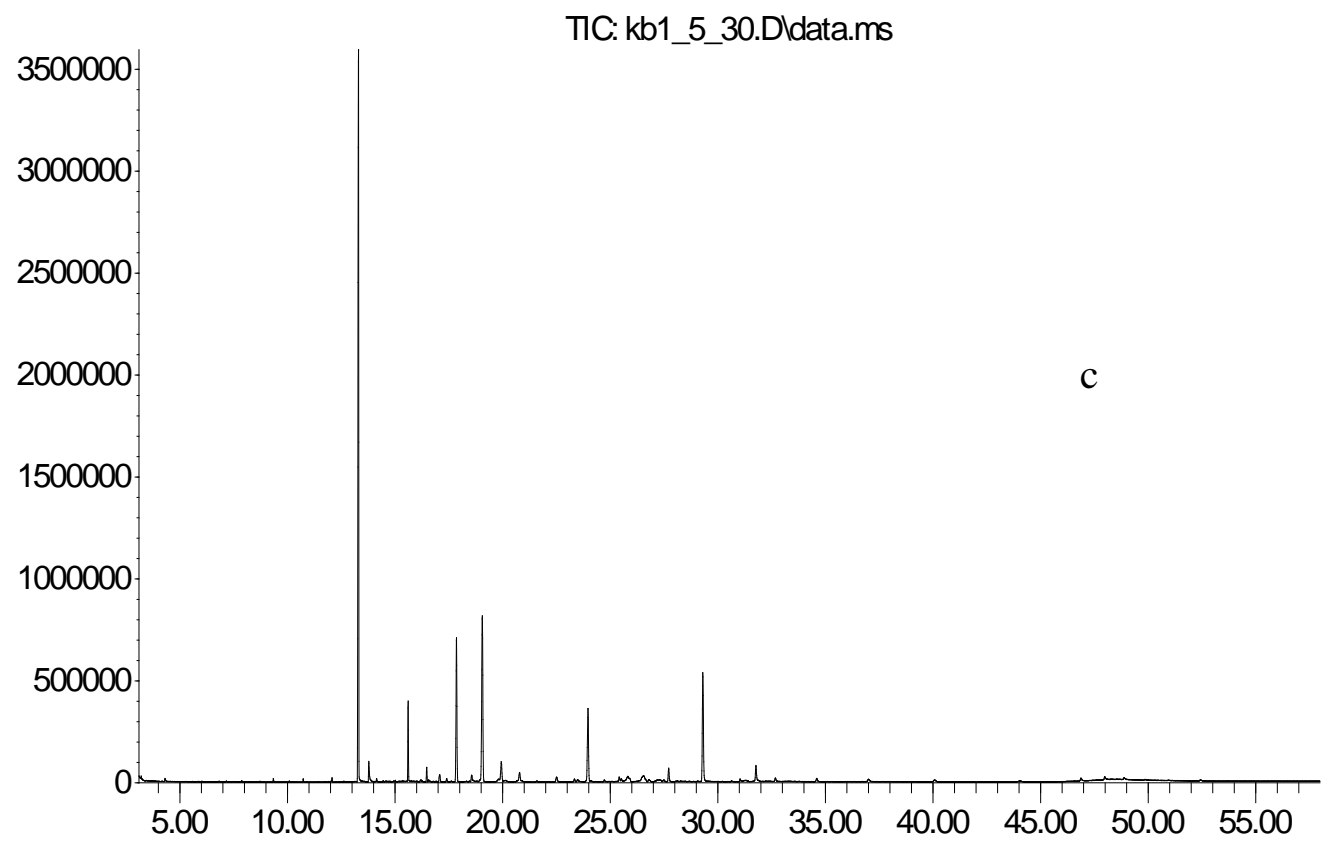

Time-->

Abundance

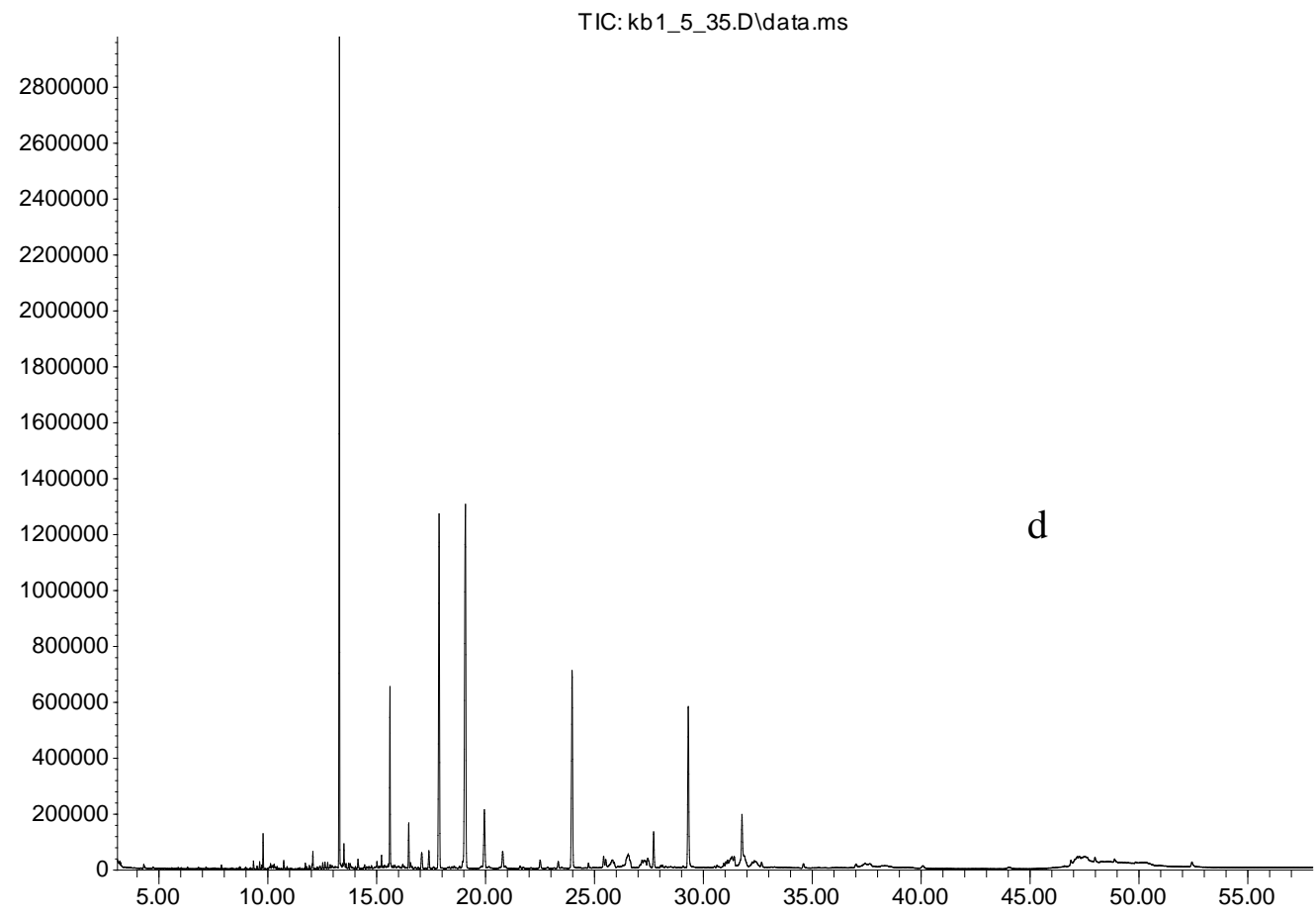

Time--> 
M. List of fatty acids found in Kb1-2, Kb1-3, Kb1-5 and T. lutea based on GC-MS at 20, 25 and 35 psu

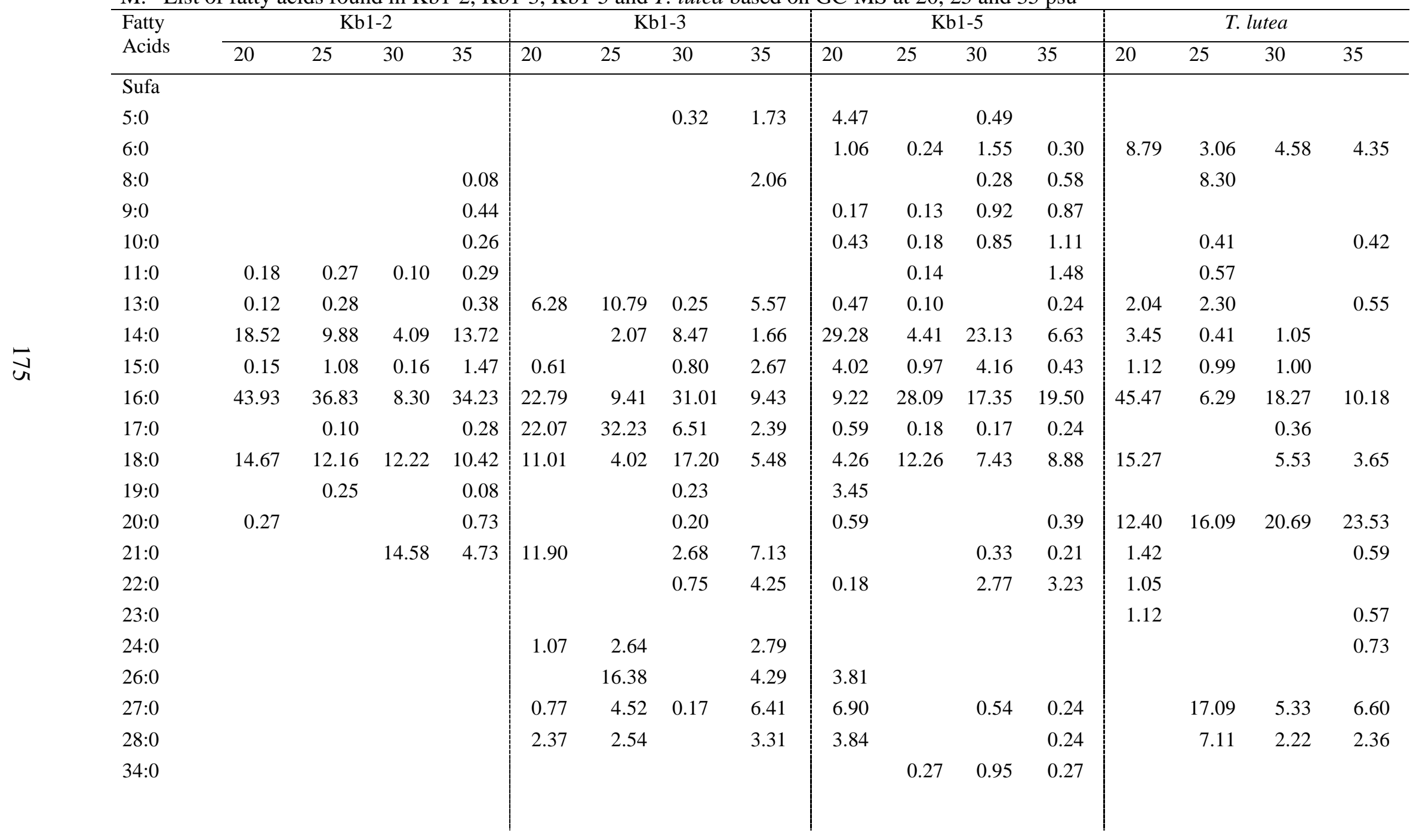




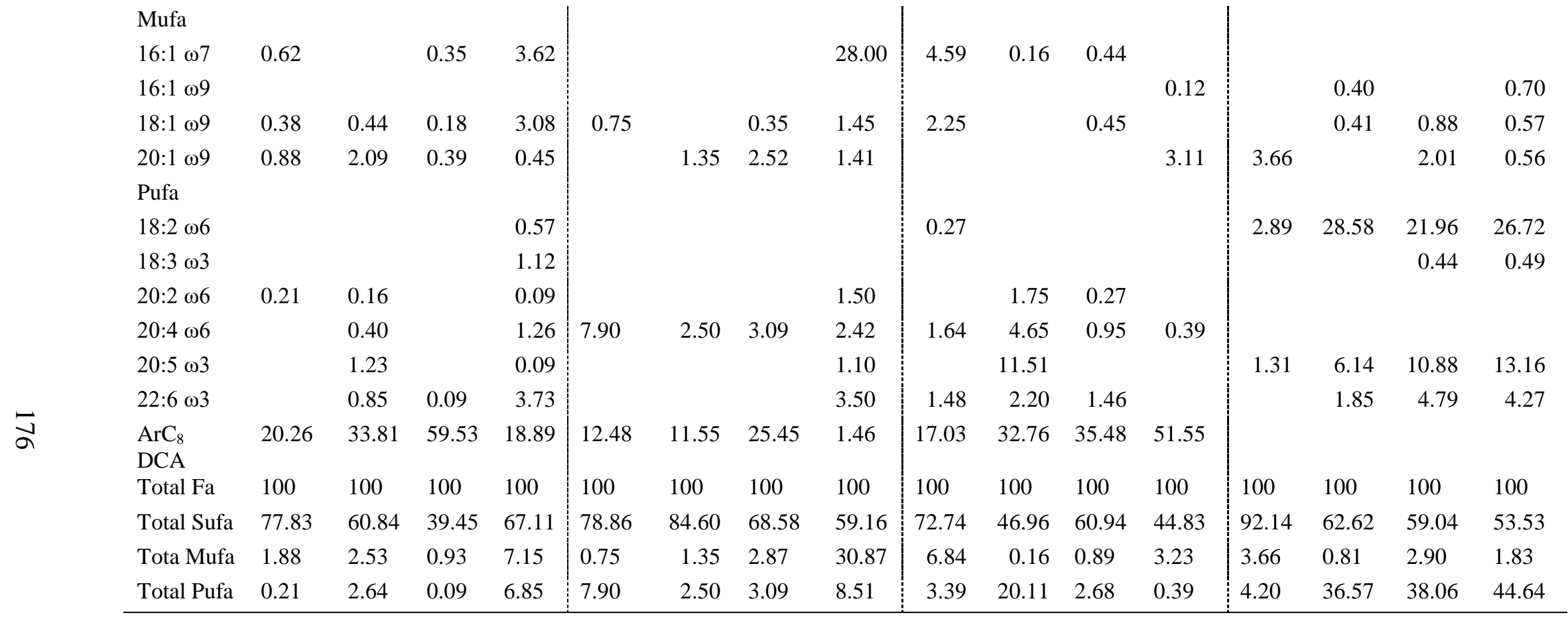

